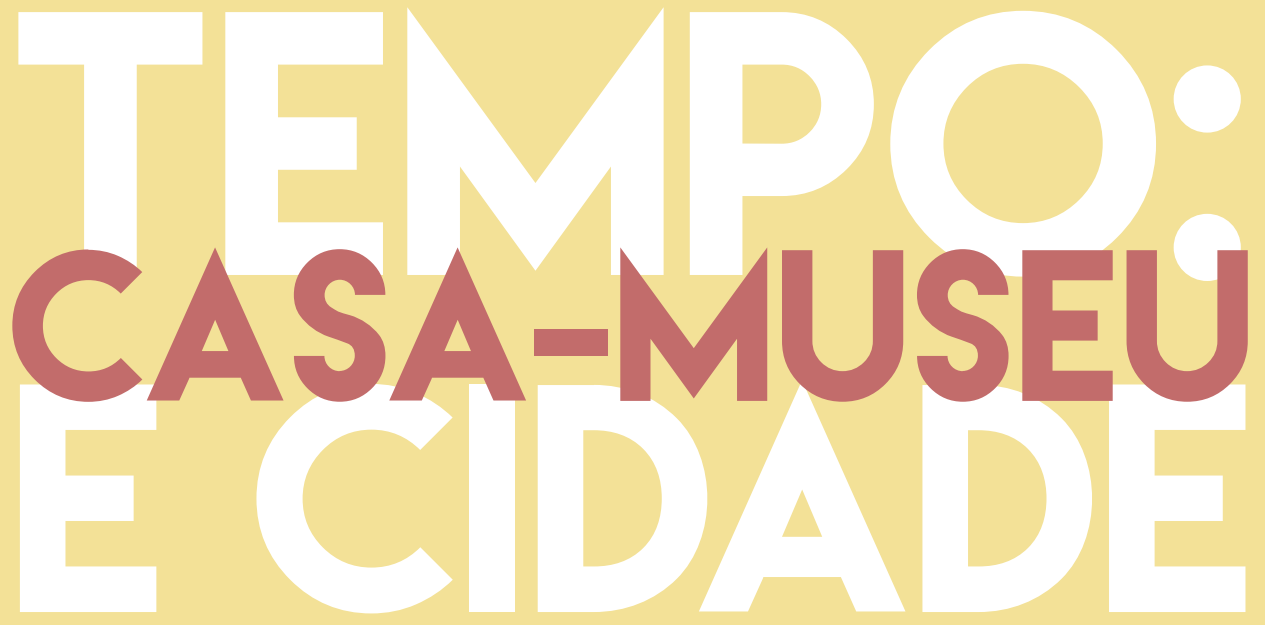

PAULO EDUARDO BARBOSA 



\section{UNIVERSIDADE DE SÃO PAULO \\ FACULDADE DE ARQUUTETURA E URBAnISTO}

\section{PAULO EDUARDO BARBOSA}

\section{TEMPO: CASA-MUSEU E CIDADE}

SÃO PAULO

2020 



\section{PAULO EDUARDO BARBOSA}

\section{TEMPO: CASA-MUSEU E CIDADE}

Tese apresentada a Faculdade de Arquitetura e Urbanismo da Universidade de São Paulo para obtenção do título de doutor em Arquitetura

ÁREA DE CONCEnTRAÇÃO:

Projeto, Espaço e Cultura - PEC

ORIENTADORA:

Profa Drạ Maria Cecília França Lourenço

SÃO PAULO

2020 
AUTORIZO A REPRODUÇÃO E DIVULGAÇÃO TOTAL OU PARCIAL DESTE TRABALHO, POR QUALQUER MEIO CONVENCIONAL OU ELETRÔNICO, DESDE QUE CITADA A FONTE.

Email: pebarbosa@usp.br

Catalogação na Publicação

Serviço Técnico de Biblioteca

Faculdade de Arquitetura e Urbanismo da Universidade de São Paulo Elaborada eletronicamente através do formulário disponível em: http://www.fau.usp.br/fichacatalografica/

Barbosa, Paulo Eduardo

Tempo: casa-museu e cidade / Paulo Eduardo Barbosa;

orientadora Maria Cecília França Lourenço. - São Paulo, 2020. $165 p$.

Tese (Doutorado) - Faculdade de Arquitetura e Urbanismo da Universidade de São Paulo. Área de concentração: Projeto, Espaço e Cultura.

1. Casas-museu. 2. Arte. 3. Recepção. 4. Cidade. I. Lourenço, Maria Cecília França, orient. II. Título. 
Nome: BARBOSA, Paulo Eduardo

Título: Tempo: casa-museu e cidade

Tese apresentada a Faculdade de Arquitetura e

Urbanismo da Univesidade de São Paulo para

obtenção do título de doutor em Arquitetura

Área de Concentração: Projeto, Espaço e

Cultura - PEC

Aprovado em:

Banca Examinadora

Prof. Dr.

Instituição:

Julgamento:

Assinatura:

Prof. Dr.

Instituição:

Julgamento:

Assinatura:

Prof. Dr.

Instituição:

Julgamento:

Assinatura:

Prof. Dr.

Instituição:

Julgamento:

Assinatura: 

Aos netos 



\section{AGRADECIMENTOS}

Agradeço aos museus, em especial aos trabalhadores em casas-museus que, generosamente me concedem tempo, atenção e acesso a seus arquivos, movidos pela confiança e esperança na pesquisa acadêmica como meio de qualificar o papel destas instituições em nossas comunidades. Agradeço muito a cada um dos colegas do Grupo Museu/Patrimônio GMP-FAUUSP, funcionários e professores do programa de pós-graduação da FAUUSP, acadêmicos de universidades brasileiras e estrangeiras que conheço pelos encontros, seminários e congressos que tenho participado. Reconheço gratidão aos passados, presentes e futuros colegas arquitetos, companheiros nas atividades e inquietações de variadas naturezas que constroem em mim a consciência sincera de que o trabalho aqui apresentado tem uma base coletiva. À minha família e à minha companheira Márcia agradeço o apoio e a companhia nesta trajetória. À minha orientadora Profa Maria Cecília França Lourenço, querida Ciça, o meu profundo sentimento de respeito e reconhecimento por poder compartilhar de sua delicadeza, espírito acadêmico e senso de dever público, tão raros. Obrigado mesmo, Ciça. 

"De uma cidade, não aproveitamos as suas sete ou setenta e sete maravilhas, mas a resposta que dá às nossas perguntas"

Marco Polo a Kublai Khan, em As cidades Invisíveis

Ítalo Calvino 



\section{Tempo: casa-museu e cidade}

\section{RESUMO}

Neste estudo procura-se analisar instituição, patrimonialização, concepção e atuação da modalidade museal denominada casa-museu, a partir de investigação e fruição voltadas a unidades nacionais e internacionais. Conceitos sobre museu, arte, recepção, representação fundamentam-se em pensadores, conselhos e organismo representativos. A observação das conjunções tanto relativas à casa, casa-museu e cidade, quanto entre elas e a arte contemporânea favorecem a fricção de conteúdos e temporalidades. Propõe-se a dinamização das narrativas elaboradas e a formação de conjuntos, vindo a configurar rede de museus de habitação e cultura urbana, renovando periodicamente a visitação e interpretação da referida tipologia em exame.

Palavras chave: Casa-museu, artes, cidade, rede, recepção, representação. 


\title{
Time: house-museum and city
}

\begin{abstract}
This study aims to analyze the institution, patrimonialization, conception and performance of the museal modality named house-museum, based on research and fruition aimed at national and international units. Concepts about museum, art, reception, representation are based on researchers, councils and representative bodies. The observation of conjunctions both related to the house, house-museum and city, as well as between them and contemporary art favor the friction of contents and temporalities. It is proposed to stimulate the elaborated narratives and the formation of entirety, setting up a network of museums concerning housing and urban culture, periodically renewing the visitation and interpretation of the typology under examination.
\end{abstract}

Keywords: House-museum, arts, city, network, reception, representation. 


\section{Tiempo: casa museo y ciudad}

\section{RESUMEN}

Este estudio busca analizar la institución, la patrimonialización, la concepción y el desempeño de la modalidad museal llamada casa museo, basada en la investigación y el disfrute dirigido a unidades nacionales e internacionales. Los conceptos sobre museo, arte, recepción, representación se basan en pensadores, consejos y organismos representativos. La observación de conjunciones relacionadas tanto con la casa, la casa-museo y la ciudad, como entre ellas y el arte contemporáneo, favorecen la fricción de contenidos y temporalidades. Se propone estimular las narrativas elaboradas y la formación de grupos, formando una red de museos de vivienda y cultura urbana, renovando periódicamente la visita e interpretación de la tipología bajo examen.

Palabras clave: Casa museo, arte, ciudad, red, recepción, representación.

\section{Temps: Maison-museé et ville}

\section{RÉSUMÉ}

L'objectif de cette étude est d'analiser l'institution, la patrimonialisation, la conception et le rôle de la modalité muséale dénommée maison-musée à partir de l'investigation et de la fruition portant sur des unités nationales et internationales. Les concepts sur lesquels nous travaillerons concernant le musée, l'art, la réception et la représentation s'appuieront sur les idées de quelques penseurs et sur la contribution des conseils et des organismes représentatifs en ce domaine. L'observation des conjonctions se rapportant à la maison, à la maison-musée et à la ville et de celles entre elles et l'art contemporain favorisent la friction des contenus et des temporalités. Nous envisageons la dynamisation des narratives élaborées et la formation des ensembles qui configurent un réseau de musées d'habitation et de culture urbaine en renouvelant régulièrement la visite et l'interprétation de la typologie que nous nous proposons d'examiner.

Mots-clés : maison-musée, arts, ville, réseau, réception, représentation. 



\section{Lista de imagens}

Fig. 1 - Sir John Soane's Museum, Londres, Reino Unido. Fachada. 2012. Foto A.

Fig. 2 - Mapa de Lincoln Inn Fields, Londres, Reino Unido. 1799 Arquivo Sir John Soane's Museum.

Fig. 3 - Maison de Balzac, Paris, França. 2016. Foto A.

Fig. 4 - Maison Victor Hugo, Paris, França. 2016. Foto A.

Fig. 5 - Museé Jacqmart-André, Paris, França. 2016. Foto A

Fig. 6 - Museé Nissim de Camondo, Paris, França. 2016. Foto A.

Fig. 7 - Nishi Chaya Shiryokan Museum, Kanazawa, Japão. Genkan. 2019. Foto A.

Fig. 8 - Muro Saisei Kinenkan Museum, Kanazawa, Japão. Fachada. 2019. Foto A.

Fig. 9 - Muro Saisei Kinenkan Museum, Kanazawa, Japão. Mapa de Kanazawa. 2019. Foto A.

Fig. 10 - Nishi Chaya Shiryokan Museum, Kanazawa, Japão. Fachada. 2019. Foto A.

Fig. 11 - Kawai Kanjiro Memorial Museum, Kyoto. Fachada. 2019 Márcia Rossi.

Fig. 12 - Kawai Kanjiro Memorial Museum, Kyoto. Tornos do ateliê. 2019. Márcia Rossi.

Fig. 13 - Museu Casa de Guimarães Rosa, Cordisburgo, MG. Mapa de Cordisburgo. 2017. Foto A.

Fig. 14 - Museu Casa de Portinari, Brodósqui, SP. Maquete virtual da casa. 2018. Foto A.

Fig. 15 - Ilustração em aquarela e bico de pena feita por Cícero Dias para o livro Casa Grande \& Senzala. Acervo da Fundação Magdalena e Gilberto Freyre. Fonte: https://br.pinterest.com./ 
pin/548242954617366208/ acessado em 02/2/2018.

Fig. 16 - Casa-museu Magdalena e Gillberto Freyre, Recife, PE. 2018 Foto A.

Fig. 17 - Casa de Rui Barbosa, Rio de Janeiro, RJ. Fachada. Fonte: www.casaruibarbosa.gov.br

Fig. 18 - Casa de Rui Barbosa, Rio de Janeiro, RJ. Imagem aérea. 2020. Desenho do autor sobre imagem Google maps.

Fig. 19 - Casa do Conselheiro Rodrigues Alves, Guaratinguetá, SP. Fachada. Foto A.

Fig. 20 - Museus Históricos Paulistas (1956 - 1970). Fonte: (Campos, c. 1970)

Fig. 21 - Casa do Conselheiro Rodrigues Alves, Guaratinguetá, SP. Sala de estar da antiga museografia. Arquivo Casa do ConseIheiro Rodrigues Alves.

Fig. 22 - Vista do bairro do Pacaembu a partir da janela da mansarda. Guilherme de Almeida. Aquarela sobre papel canson. Década de 1940. Arquivo Casa Guilherme de Almeida.

Fig. 23 - Casa Guilherme de Almeida, São Paulo, SP. Fachada. Foto A.

Fig. 24 - Guilherme de Almeida em casa com seu cachorro Ling Ling, São Paulo, SP. c. 1960. Arquivo Casa Guilherme de Almeida.

Fig. 25 - Guilherme de Almeida no interior da mansarda, São Paulo, SP. c.1960. Arquivo Casa Guilherme de Almeida.

Fig. 26 - Sala de estar da Casa Guilherme de Almeida musealizada. 2016. Arquivo Casa Guilherme de Almeida.

Fig. 27 - Mansarda musealizada da Casa Guilherme de Almeida, São Paulo, SP. 2016. Arquivo Casa Guilherme de Almeida.

Fig. 28 - Fundação Maria Luísa e Oscar Americano, São Paulo, SP. Fachada. 2017. Foto A.

Fig. 29 - Escritório da residência Oscar Americano. Arquiteto Oswaldo 
Bratke/ interiores: Branco e Preto. 1956. Foto: Peter Scheier.. Arquivo da Fundação Maria Luísa e Oscar Americano.

Fig. 30 - Fundação Maria Luísa e Oscar Americano, gabinete do escritório da casa musealizada. 1980. Foto Renato Leary. Arquivo da Fundação Maria Luísa e Oscar Americano.

Fig. 31 - Piscina e pavilhão da residência Oscar Americano. Arquiteto Oswaldo Bratke/ paisagista Otávio A.T. Mendes. 1956. Foto: Peter Scheier. Arquivo da Fundação Maria Luísa e Oscar Americano.

Fig 32 - Fundação Maria Luísa e Oscar Americano, pavilhão e piscina soterrada. 2016. Márcia Rossi.

Fig. 33 - Sala de estar da residência Oscar Americano. Arquiteto Oswaldo Bratke/ interiores: Branco e Preto. 1956. Foto: Peter Scheier. Arquivo da Fundação Maria Luísa e Oscar Americano.

Fig. 34 - Fundação Maria Luísa e Oscar Americano, Sala de estar musealizada. 1980. Foto Renato Leary. Arquivo da Fundação Maria Luísa e Oscar Americano.

Fig. 35 - Jardim da residência Oscar Americano. Paisagista: Otávio A. T. Mendes. 1956. Foto: Peter Scheier. Arquivo da Fundação Maria Luísa e Oscar Americano.

Fig. 36 - Dormitório de filhos, da residência Oscar Americano. Arquiteto Oswaldo Bratke/ interiores: Branco e Preto. 1956. Foto: Peter Scheier. Arquivo da Fundação Maria Luísa e Oscar Americano.

Fig. 37 - Fachada da residência Oscar Americano. Arquiteto Oswaldo Bratke/ interiores: Branco e Preto. 1956. Foto: Peter Scheier. Arquivo da Fundação Maria Luísa e Oscar Americano.

Fig. 38 - Fundação Maria Luísa e Oscar Americano, dormitório do casal musealizado. 1980. Foto Renato Leary. Arquivo da Fundação Maria Luísa e Oscar Americano.

Fig. 39 - Mapa da região do Morumbi, São Paulo, SP. 2020. Desenho do autor sobre arquivo digital. 
Fig. 40 - Museé Nissim de Camondo, Paris, França. Fachada. 2016. (Museé Nissim de Camondo, 2007, p.72)

Fig. 41 - Mapa do loteamento do Parc Monceau em Paris. 2018. Desenho do autor sobre imagem digital de arquivo do Museé Nissim de Camondo. Fonte: (Museé Nissim de Camondo, 2007, p. 58)

Fig. 42 - Planta do vestíbulo da residência Moïse de Camondo. Arquiteto René Sergent. Fonte: (Museé Nissim de Camondo, 2007, p. 79)

Fig. 43 - Sir John Soane's Museum, exposição "Power in Woman", obra da artista Sarah Lucas. 2016. Fonte: http://moussemagazine.it/sarah-lucas-sir-john-soane-museum-2016/

Fig. 44 - Lina Bo Bardi . Perspectiva interna da sala da Casa de Vidro, s/d. Nanquim sobre papel offset. 10,6 x 11,8 cm. Arquivo Instituto Bardi/ Casa de Vidro

Fig. 45 - Casa de Vidro, exposição "O interior está no exterior" curadoria Hans Ulrich Olbrist. Instalação de Gilbert \& George. 2013. Fonte: http://www.ovitro.com.br/2013/05/24/casa-de-vidro-_-hans-ulrich-obrist-the-insides-are-on-the-outside-_-morumbi/

Fig. 46 - Casa de Vidro. Fachada. 2017. Foto A.

Fig. 47 - Duas vistas da cidade de São Paulo, s/d. Esferográfica e grafite sobre papel offset. 11,5 × 14,2 cm. Arquivo Instituto Bardi/ Casa de Vidro.

Fig 48 - Fundação Eva Klabin, Rio de Janeiro, RJ. Fachada com intervenção da artista Regina Silveira. Projeto Respiração 21ํㅡ edição 27 de setembro de 2016 a 29 de janeiro de 2017. Fonte: encurtador.com.br/qKLRU

Fig. 49 - Freud Museum, Londres, Reino Unido. Intervenção de Miroslaw Balka Die Traumdeutung . 2014. Fonte: https://www. freud.org.uk/exhibitions/miroslaw-balka-die-traumdeutung/ 


\section{Lista de pranchas}

Prancha 1 - Casa do Conselheiro Rodrigues Alves,

Guaratinguetá, SP.

Prancha 2 - Casa Guilherme de Almeida, Sumarezinho,

São Paulo, SP.

Prancha 3 - Fundação Maria Luísa e Oscar Americano, Morumbi, São Paulo, SP.

Prancha 4 - Casa de Vidro/ Instituto Bardi, Morumbi, São Paulo, SP.

Prancha 5 - Fundação Eva Klabin, Rio de Janeiro, RJ 


\section{LISTA DE SIGLAS}

Conselho de Defesa do Patrimônio Histórico,

Condephaat Arqueológico,Artístico e Turístico do estado de São Paulo

CICC

Comitê Internacional de Cooperação Cultural

Demhist Comitê para casa históricas do Icom

(Demeure hitorique musées)

Departamento do Patrimônio Histórico da

$\mathrm{DPH}$

Prefeitura Municipal de São Paulo

EIM

Escritório Internacional de Museus

Conselho Internacional de Museu

ICOM

(Inernational Council of Museums)

Conselho Internacional de Monumentos e

Icomos

Sítios

Instituto do Patrimônio Histórico e Artístico

IPHAN

Nacional

MHP

Museu Histórico e Pedagógico

Sisem SP

Sistema Estadual de Museus do estado de São Paulo

Unesco Organização das Nações Unidas para a Educação, a Ciência e a Cultura 


\section{SUMÁRIO}

\section{Introdução}

\section{Capítulo 1- Casa-museu: espaço e lugar}

1. Casa-museu, museu-casa

2. Museu e coleção

3. Casas-museu e cidades
a. Sir John Soane's Museum, Londres, Reino Unido
b. Maison de Balzac, Paris, França
c. Maison Victor Hugo, Paris, França
d. Museé Jacamart-André, Paris, França
e. Museé Nissim de Camondo, Paris, França
f. Muro Sansei Museum, Kanazawa, Japão
g. Nishi Chaya Shriyokan, Kanazawa, Japão
h. Kawai Kanjiro's House, Kyoto, Japão

Prancha 1 - Casa do Conselheiro Rodrigues Alves, Guaratinguetá, SP

\section{Capítulo 2- Enredos em disputa}

1. Casa-museu Magdalena e Gilberto Freyre, Recife, PE Conceitos
a. Milton Santos
b. Michel de Certeau

2. Memória edificada

3. Casa de Rui Barbosa, Rio de Janeiro, RJ

4. Casa do Conselheiro Rodrigues Alves, Guaratinguetá, SP

c. A construção da nação paulista

d. $\bigcirc$ enredo

e. O tombamento do imóvel pelo IPHAN

f. O IPHAN e casas históricas

Prancha 2 - Casa Guilherme de Almeida, Sumarezinho, São Paulo, SP

\section{Capítulo 3- Por um museu da casa}

1. Desnaturalizando a casa-museu

2. Casa Guilherme de Almeida, São Paulo, SP
a. Casa-museu e domesticidade
b. Entre arquitetura e personagem
c. Rede de museus literários
Conceitos

a. Charles Saummarez Smith 
b. Henri Lefebvre

c. Milton Santos

d. Stuart Hall

Prancha 3 - Fundação Maria Luísa e Oscar Americano, Morumbi, São Paulo, SP

3. Fundação Maria Luísa e Oscar Americano, São Paulo, SP

e. Casa-museu latino-americana

f. Projeto modernista 1950 - síntese das artes

g. Casa-cidade

h. O jardim

i. O mobiliário

j. A sede da Fundação Maria Luísa e Oscar Americano em São Paulo

Prancha 4 - Casa de Vidro/ Instituto Bardi, Morumbi, São Paulo, SP

\section{Capítulo 4- Arte contemporânea na casa-museu}

1. Tempo

Conceitos

Michel de Certeau

b. Charles Saummarez Smith

c. Giorgio Agamben

d. Milton Santos

e. Hans Robert Jauss

f. Georges Didi-Huberman

g. Krzysztof Pomian

h. Roger Chartier

i. Miwon Kwon

2. Camondo e Soane

3. Eva e Lina 3

j. Casa de Vidro, São Paulo, SP

k. Casa da Fundação Eva Klabin, Rio de Janeiro, RJ

4. Arte site-specific

Prancha 5 - Fundação Eva Klabin, Rio de Janeiro, RJ

\section{Conclusões}

\section{Bibliografia}




\section{Introdução}

Debater os museus no âmbito da arquitetura e suas relações com a cidade tem sido meu interesse desde a realização da pesquisa de mestrado, quando analisei conexões entre a arquitetura e a casa-museu. A modalidade funda tipologia específica de instituição dedicada à memória ${ }^{1}$, cujo acervo inclui o edifício, seus interiores e jardim, com o intuito de ampliar a atuação destas instituições na vinculação entre memórias individuais àquelas coletivas de distintas comunidades. Ademais, a tensão entre museu e monumento permitiria qualificar a relação entre estes e diferentes segmentos de receptores, como maneira de potencializar a formação, prática e frequentação.

Ao dar continuidade às investigações, neste trabalho de doutorado, proponho a hipótese sobre a importância da imbricação casa-cidade, atestada na dinâmica da malha urbana em que se insere a residência, conferindo condição documental à arquitetura e dinamizando as relações das instituições culturais. Categorias específicas da residência, postas em tensão quanto ao enredo elaborado pelo projeto museológico, favoreceriam a apreensão do fato arquitetônico ${ }^{2}$, naturalizado pela representação mimética, ordenado como expressão material de narrativas, em diálogo com poéticas de cada tempo e expressas pela arte e museologia. Em face das novas demandas criadas em instituições e redes museais coadunadas à condição contemporânea de valorização do ordinário em detrimento ao raro ou excepcional, pretendo provar e sustentar a tese de que a tipologia, ao qualificar museu, arquitetura e arte desta época, enseja a construção de rede constituida por casas-museu em trocas com aquelas outras instituições culturais existentes no entorno.

As casas-museu, modalidade específica de organização museal, contempladas pelo Conselho Internacional de Museus (ICOM), espaIhadas por todo o território brasileiro, em cidades de múltiplas escalas e complexidades, compondo conjunto de grande diversidade, têm sido objeto de pesquisas desenvolvidas em disciplinas como Museologia,

1. Trata-se aqui da memória como instância de presentificação do ausente, em tensão com a imaginação, segundo Paul Ricoeur, pela sua posição de um real anterior, oposta à "suspensão de toda posição de realidade e a visão de um irreal" (2007, p. 61).

2. Fato arquitetônico como proposto por Bruno Zevi, no livro Saber ver a arquitetura, de 1948 , fundamentado na asserção "o espaço interior [...] não pode ser representado perfeitamente em nenhuma forma, que não pode ser conhecido e vivido a não ser por experiência direta, é o protagonista do fato arquitetônico." (2009, p. 18). 
História e, muito raramente, Arte, Arquitetura e Urbanismo 3 . Abertas à visitação nos núcleos urbanos em que se encontram, estas casas de escritores, pintores, líderes comunitários, artistas e personagens históricas, alçadas à categoria de patrimônio e preservadas em condições bastante heterogêneas, se apresentam, para além dos enredos que materializam, como depoimentos relativos aos modos de morar e à conformação das cidades. Levantamento recente ${ }^{4}$ aponta mais de 300 unidades museais no Brasil que se caracterizariam como casas-museu ${ }^{5}$, segundo critérios estabelecidos pelo Comitê Internacional para os Museus de Casas Históricas (Demhist-ICOM) ${ }^{6}$.

Embora a instituição de uma casa-museu responda, em cada caso, às mais diversas iniciativas, demarcando um conjunto limitado de características a serem consideradas comuns a este extenso grupo, no Brasil, inclui enorme diversidade. Abrange, desde a casa de Chico Mendes, em Xapuri, no estado do Acre, ao Museu da República, no Palácio do Catete, no Rio de Janeiro. Entre as poucas similaridades, malgrado a obviedade, interessa nesta pesquisa o aspecto de terem sido instaladas em edificações construídas originalmente para fins residenciais e, hoje, atenderem a uma função pública, própria dos museus na atualidade. Podem assim, revelar camadas constitutivas da cidade contemporânea ao suscitar debates sobre cidade e urbanidade e o papel da arquitetura dessas residências privadas na resposta à nova função dita pública assumida, alterando a dinâmica destas categorias.

Os objetivos destas casas, expressos pelas ações de seus dirigentes, funcionários e pelos planos museológicos, que nem sempre

3. São dois os trabalhos digitalizados e localizados que versam sobre casas-museu listados no Banco de Teses da Universidade de São Paulo (USP) um na Universidade Federal de Minas Gerais (UFMG) e nenhum na Universidade Estadual de Campinas (Unicamp) ou na Universidade Federal do Rio de Janeiro (UFRJ). Vale ressaltar que pode haver outros, anteriores a 2001, ano inicial em São Paulo para a digitalização como prática tecnológica e cujo acesso passa a ser mais restrito. No site do Grupo Museu/ Patrimônio encontra-se disponível lista de teses, cujos temas referem-se a museus em geral. Disponível em: $<$ http//:www.museupatrimonio.fau.usp.br.>. Acesso a: 26/06/2019.

4. Em 2013, foi publicado trabalho de catalogação, coordenado pela Curadoria do Acervo Artístico-Cultural dos Palácios do Governo do Estado de São Paulo, organizado por Ana Cristina Carvalho, que procurou cobrir todos os estados brasileiros relacionando mais de 300 instituições, de acordo com os critérios de catalogação de casas-museu propostos no contexto de um trabalho sistemático desenvolvido pelo Demhist (Carvalho, 2013).

5. Note-se que nem sempre se denominam desta forma casas-museu, mas comumente museus-casa ou casas históricas. Mais adiante, apresentarei argumentação a favor da forma escolhida nesta pesquisa.

6. Demhist (Demeures Historiques-musées, Comité International pour les Demeures Historiques-musées) é o comitê específico do ICOM para as casas-museu e sua criação, em 1998, responde a uma demanda das instituições museais instaladas em casas históricas e palácios europeus, por especificidade na definição de critérios e políticas museológicas. Houve grande expansão deste comitê no sentido de sua mundialização que o obrigou a contemplar diversas escalas de casas-museu. 
possuem, frequentemente, se propõem a materializar um enredo de vida privada. No entanto, pouco desafiam as expectativas relativas às personagens públicas que homenageiam, formulando reiteração muitas vezes edulcorada de aspectos disseminados pela história oficial, não raro, a veiculada pela própria instituição.

A implantação dessas instituições culturais em edifícios originalmente residenciais impõe temas condicionantes à necessária acomodação, à manutenção predial, à iluminação, à exposição, à criação de áreas técnicas para preservação de acervos, acessos e facilidades ao público, entre outras, que têm sido objeto da Arquitetura. As adaptações, ademais, deveriam em princípio considerar e lidar de maneira cautelosa com elementos constitutivos de certa domesticidade?, embora se trate de qualificar espaço museal para atividades que hoje desenvolvem. Ressaltem-se, entre tantas, foco em diferentes públicos e recepções diversas, implicando conservar na casa-museu, entre outros elementos, escalas de ambientes residenciais, distribuição de mobiliário compatibilizada com percursos e, ainda, que a conjectura expressa pelo projeto museológico não seja a da mimese e haja uma compreensão ampliada e crítica capaz de desobrigar o compromisso de reconstituição fiel da parte social nos ambientes domésticos, que podem ser documentados, há sempre o limite do edifício que é acervo $^{8}$ e, portanto, item a ser conservado, a despeito das necessidades impostas pelo novo uso 9 .

O projeto arquitetônico, quando eventualmente ocorre ser utilizado, tem se mostrado eficiente ferramenta de articulação destas demandas na busca de configurar espaços que possam contribuir com o

7. Domesticidade considerada como um conjunto de processos em que confluem dimensões físicas e práticas culturais que conformam a habitação, relacionadas com o espaço doméstico e a cultura material, constituindo objeto de pesquisa na fronteira entre Ciências Sociais e Arquitetura (Nascimento, 2017).

8. O termo acervo, embora definido como correlato brasileiro de coleção, conforme indicado nos Conceitos-chave da Museologia, publicado pelo International Council of Museums, é utilizado aqui segundo a acepção adotada pela Fundação Oswaldo Cruz (Fiocruz), que the confere significação mais ampla, abrigando várias coleções da instituição e incluindo os fundos que contêm todos os itens a ela custodiados (Disponivel em: <https://www arca.fiocruz.br/bitstream/icict/15276/4/Programa\%20de\%20incorporao.pdf>. Acesso em 26/01/2019). Diferenciando-o de coleção, conforme concebida por Krzysztof Pomian: "qualquer conjunto de objetos naturais ou artificiais, mantidos temporária ou definitivamente fora do circuito das atividades econômicas, sujeitos a uma proteção especial em local fechado preparado para este fim e expostos ao olhar do público" (1994, p. 53).

9. Nesta tese, no trecho dedicado à Casa Guilherme de Almeida, cito o relatório elaborado pela museóloga Waldisa Rússio que discute, no processo de musealização da casa, a modificação de ambientes por meio da retirada de paredes, exemplificando a complexidade desta operação. 
cumprimento da missão preconizada pelo $\operatorname{ICOM}^{10}$, respeitando a condição de acervo destas edificações e de seus jardins, espaços de complexidades singularizadas pelo lugar, dada a conexão que promovem entre massa edificada e paisagem local.

Entre alternativas, experiências de conjunção casa-museu/espaço/arte contemporânea vislumbrariam a eficácia em vários territórios, reordenando categorias precípuas à casa-museu, cenário da vida doméstica, ao ensejar novas semânticas fundadas na arte, tendo como suporte os mesmos signos, dada a condição de precarizar aquilo que toca, inerente a determinado estatuto em que a obra se dá também na relação com o lugar. É assim que a obra site-specific, em fricção com o espaço de casas-museu, tem se afirmado como um dos instrumentos para atualização das questões propostas a estas instituições.

A tese defende qualificar a casa-museu não apenas na busca do raro nas várias áreas, para que, além de atuar como um dispositivo de afirmação de narrativas embasadas em enredos centrados na mitificação de personagens, ela possa contribuir com a compreensão do viver humano no fenômeno urbano, propondo como metodologia a observação da tensão entre temporalidades reconhecidas em dois momentos de sua existência: o de sua execução como residência privada e o de sua adaptação à função pública de museu. Visando viabilizar tal objetivo optou-se por metodologia de análise comparativa, não apenas na semelhança, mas estendendo a outras. Abordo o tema partindo do particular para o geral, utilizando fontes primárias, depoimentos e análises de distintos textos.

Fichas sobre as casas-museu objeto de estudo são apresentadas contendo as plantas da residência, como foi concebida originalmente, plantas da casa-museu no momento da coleta de dados da pesquisa com as respectivas fichas técnicas e comparações entre as inserções em malha urbana ao tempo da residência e atual. A representação gráfica utilizada objetiva oferecer parâmetros à tese defendida neste trabalho que conecta a casa-museu à cidade em que se insere enquanto contempla regularidade metodológica ${ }^{11}$.

10. A definição de museu do ICOM, válida no momento de finalização desta pesquisa, segue sendo esta: "O museu é uma instituição permanente sem fins lucrativos, ao serviço da sociedade e do seu desenvolvimento, aberta ao público, que adquire, conserva, investiga, comunica e expõe o patrimônio material e imaterial da humanidade e do seu meio envolvente com fins de educação, estudo e deleite." (Disponivel em: <http://icom-portugal. org/2015/03/19/definicao-museu/>. Acesso a: 26/05/2019). Mais adiante, serão discutidos os caminhos adotados pela instituição em busca de uma nova definição.

11. Agradeço à Profa Dr $\underline{a}$ Regina Lara Silveira Mello a sugestão metodológica e à Prof Dr $^{\underline{a}}$ Renata Vieira da Motta a relativa às bases gráficas, ambas oferecidas na Banca de Qualificação desta tese. 


\section{Referenciais teóricos}

Ainda que o cerne da pesquisa seja formado pelo par arquitetura e museus, procuro neste estudo que o aprofundamento das discussões seja apoiado por princípios e entendimentos a eles vinculados e deles expansivos. Assim, pensando em variados leitores, introduzo os fundamentos teóricos sobre os quais é erigido este doutorado, a fim de traçar um mapa de relações entre conceitos que guiaram minha aproximação ao objeto de estudo da pesquisa e sustentam a tese aqui apresentada, entre os quais destaco os de espaço, recepção, representação e dispositivo. ${ }^{12}$

Observo o espaço arquitetônico a partir da relação entre os conceitos de autores como Bruno Zevi $i^{13}$ e Milton Santos ${ }^{14}$. $O$ primeiro vê como elemento principal da arquitetura o espaço interior e o espaço da cidade, e propõe, a seu momento, uma revisão da crítica da Arquitetura com base no pressuposto de que "[...] a interpretação espacial constitui o atributo necessário de toda possivel interpretação se esta quiser ter um sentido concreto, profundo, compreensivo em matéria de arquitetura." (2009, p. 192). Sugere desta maneira não disputar caminho com as outras disciplinas que do espaço se ocupam, afirmando que o conteúdo social, o efeito psicológico e os valores formais se materializam todos no espaço. Interpretar o espaço, para o autor, significa por isso incluir todas as realidades de um edifício, inclusive a continuidade da experiência ${ }^{15}$ espacial desde o interior na direção dos espaços externos configurados pelas ruas, praças, parques das

12. Contribuíram de forma definitiva à compreensão e aprofundamento dos conceitos teóricos que aportam a tese aqui defendida a companhia e o debate valiosos dos colegas nas visitas técnicas a museus, leituras e séries de Seminários Regulares do Grupo Museu/ Patrimônio da Faculdade de Arquitetura e Urbanismo da Universidade de São Paulo - GMP FAUUSP, do qual sou membro desde o ano de 2010, coordenado pela Prof $\underline{a}$ Dra Maria Cecília França Lourenço.

13. Bruno Zevi (1918-2000), arquiteto italiano, formado na Graduate School of Design da Universidade de Harvard, em 1942, sob a direção de Walter Gropius, construiu importante crítica ao racionalismo defendido por arquitetos modernos, como Le Corbusier e Gropius, disseminando o pensamento de Frank Lloyd Wright acerca da arquitetura orgânica. Zevi fundou em Roma a revista La Cultura della Vita, em 1946, juntamente com Carlo Pagani e Lina Bo. Em 1954 publicou na revista L'espresso o texto "A moda lecorbusiana no Brasil", no qual corrobora as críticas de Max Bill à reprodução indiscriminada das formas do edifício do Ministério da Cultura no Rio de Janeiro pelos arquitetos brasileiros.

14. Milton Santos (1926-2001), graduado em Direito pela Universidade da Bahia, doutor em Geografia pela Universidade de Estrasburgo, na França, após a instauração da Ditadura Militar no Brasil, ensinou em diversas universidades na Europa, na África e na América do Sul e do Norte. Foi consultor da Organização das Nações Unidas (ONU) e da Organização Internacional do Trabalho (OIT), de cujo Comitê para o Estudo da Urbanização e do Emprego foi membro diretor. Doutor Honoris Causa por universidades do Brasil, Itália, França, entre outras. Foi professor da Universidade de São Paulo. Fonte: (Santos, 2017).

15. Conforme Agamben em seu texto "Infância e história: ensaio sobre a destruição da experiência" (2008) 
cidades, resguardando ao espaço interior da arquitetura a condição de fato arquitetônico que não pode ser conhecido e vivido senão por experiência direta.

A compreensão de Zevi considera que as arquiteturas de Frank Lloyd Wright e Alvar Aalto responderam de forma mais complexa às exigências funcionais, incluindo, entre os fatores determinantes de projeto, a psicologia do homem para além da técnica e da utilidade, concorrendo a uma humanização da arquitetura, a seu ver, carente no funcionalismo preconizado por Le Corbusier. O pós-funcionalismo, que ele representa, ultrapassa nesta medida a resposta às exigências mecânicas da civilização industrial europeia que proclamou, segundo Zevi, "[...] os tabus do utilitarismo, isto é, da adesão ao objetivo prático do edifício e à técnica, e da casa de todos, padronizada e anônima." (2009, p. 125). Suas observações foram feitas em 1984, período em que a crítica arquitetônica procurava replicar ao esgotamento do projeto moderno com a teoria pós-moderna de caráter historicista, contrapondo-se a esta justamente por conferir à produção de certos arquitetos modernos um lugar de continuidade da experiência espacial na História da Arquitetura, posição que havia sido negada pela tábula rasa do funcionalismo corbusiano.

A casa, objeto desta investigação, é a casa preenchida de significados, não apenas aqueles atribuídos por meio de reconstituição original imbuída frequentemente de objetivo mitificador ou de edição da personagem que ali habitou, mas sentidos enquanto fato arquitetônico, a saber, o espaço formado de objetos técnicos, como concebido por Milton Santos, composto pelo conjunto indissociável de sistemas de objetos e sistemas de ações ${ }^{16}$. A diferenciação que Santos faz entre paisagem e espaço, fornece instrumental adequado para se observar as casas-museu.

\footnotetext{
A paisagem é o conjunto de formas que, num dado momento, exprimem as heranças que representam as sucessivas relações localizadas entre homem e natureza. O espaço são essas formas mais a vida que as anima. (2007, p. 103)
}

Santos vê o espaço como síntese de variáveis complementares: paisagem e sociedade e afirma que: "[...] cada lugar é, à sua maneira, o mundo." (2007, p. 314), reconhecendo que a categoria do cotidiano

16. Milton Santos amplia a tese marxista que considera o conjunto de forças produtivas e de reações sociais de produção no sentido de qualificar o espaço como uma expressão da dinâmica entre sistema de objetos, que condicionam a forma como se dão as ações, e o sistema de ações, que leva à criação de objetos novos ou se realiza sobre os preexistentes. Este pensamento na obra de Santos conflui para o par analítico fluxos e fixos em suas últimas obras. 
é capaz de oferecer novos significados aos lugares no mundo atual. Santos propõe pensar a cidade latino-americana como local da mobilidade e dos encontros, onde os deslocamentos são inúmeros e é intensa a geração de relações interpessoais, reconhecendo o movimento como

[...] potencializado nos países subdesenvolvidos, graças à enorme gama de situações pessoais de renda, ao tamanho desmesurado das metrópoles e ao menor coeficiente de racionalidade na operação da máquina urbana. (2007, p. 319)

Reconhece a partir deste ponto a cidade contemporânea como jogo de tensões, que pode ser subvertido pela presença dos pobres que abrem, segundo o autor, um novo debate com as populações e as coisas já presentes na cidade, reavaliando e encontrando "[...] novos usos e finalidades para objetos e técnicas e também novas normas na vida social e afetiva [...] é na esfera comunicacional que eles, diferentemente das classes ditas superiores, são fortemente ativos." (Santos, 2017, p. 326). Ao reconhecer a mobilidade como regra, reputa à circulação potência criadora maior que à produção, amparando seu conceito de desterritorialização, sinônimo para ele de desculturação, estranhamento.

"Quando o homem se defronta com um espaço que não ajudou a criar, cuja história desconhece, cuja memória lhe é estranha, esse lugar é sede de uma vigorosa alienação." (Santos, 2017, p. 328)

\begin{abstract}
A memória olha o passado. A nova consciência olha para o futuro. $\bigcirc$ espaço é um dado fundamental nesta descoberta. Ele é o teatro dessa novação por ser, ao mesmo tempo, futuro imediato e passado imediato, um presente ao mesmo tempo concluído e inconcluso, num processo sempre renovado. (2017, p. 330)
\end{abstract}

A cotidianidade alterada, da residência ao museu, subverte práticas e implica naquilo que Michel de Certeau ${ }^{17}$ denominou táticas e estratégias cujo norte deveria ser o público do museu, o visitante. Neste sentido, utilizo, neste trabalho, aspectos da Teoria Estética da

17. Michel de Certeau (1925-1986), historiador e erudito francês que se dedicou aos estudos de Psicanálise, Filosofia e Ciências Sociais, liderou pesquisa entre 1974 e 1978, na França, e publicou seus resultados em dois volumes sob o título A invenção do cotidiano - volume 1: As artes do fazer; volume 2: Morar, cozinhar. Referência em estudos de História, Ciências Sociais, Psicanálise, temas da pluralidade de enfoques e resistência, em especial contra o que denomina estratégias do poder e as táticas para afrontá-las. Entre seus outros livros se encontram História e psicanálise: entre ciência e ficção, A escrita da História e A cultura no plural. Disponível em: <https://www.historiadahistoriografia.com.br/revista/ article/viewFile/459/327/>. Acesso a: 18/11/2018. 
Recepção, concebida por Hans Robert Jauss ${ }^{18}$, pois a partir da Teoria dos Efeitos, ela torna eficiente e central a mudança do eixo de análise da obra de arte na direção de seu receptor. De acordo com Jauss, a recepção, entendida como fato social, condiciona a produção da obra de arte que ocasiona, por sua vez, um esgarçamento no que o autor chama de horizonte de expectativas do receptor. Desta maneira, compõe uma metodologia para análise da obra a partir de sua recepção, que inclui conceitos como diferença hermenêutica, sincronia e diacronia. Na defesa da Estética da Recepção, surgida no calor das mudanças ocorridas na Europa no final dos anos 1960, Jauss cita uma frase de R. G. Colingwood, que corrobora seu programa de ação: "[...] compreende-se o texto quando se compreendeu a pergunta a que ele dá a resposta." (Apud Zilbermann, 1989, p. 37).

Ao museu compete estar apto às questões da contemporaneidade e ampliar a gama de públicos a serem atendidos. Para que esta missão se cumpra, é preciso que se tornem o foco da ação museal, e que esta busque, de acordo com as teses de Jauss, ampliar os horizontes de expectativas destes visitantes e da obra, em afinidade dialética. Dado o potencial de desempenho alcançado pelas instituições museais, no contexto deste século XXI, elas não deveriam ser apenas reprodução ou reflexo dos eventos sociais, mas, sim, desempenhar um papel ativo na pré-formação e motivação do comportamento social.

Para Jauss a visita ao museu pode ser pensada como propiciadora da emancipação do sujeito, uma vez que, potencialmente, liberta o ser humano dos constrangimentos e da rotina cotidiana; precede a experiência, implicando na incorporação de novas formas, importantes para a compreensão da vida prática; e projeta vivências futuras e reconhecimento retrospectivo, ao preservar o passado e permitir a redescoberta de camadas invisíveis. Vivenciar a casa-museu poderia nos levar a compreender as perguntas às quais ela respondeu à época, editada para tanto, na perspectiva de que ela possa dar conta das questões do presente, procedendo à atualização da recepção de seu acervo.

Importante ferramenta para se pensar a casa-museu e suas possiblidades em mundo distópico é a ampliação, por Giorgio Agamben, do conceito de dispositivo, indicado por Michel Foucault, para o qual ele seria como uma rede, que se estabelece entre diversos elementos heterogêneos incluídos no mesmo título: discursos, instituições,

18. Hans Robert Jauss (1921-1997) foi professor de Teoria e História da Literatura na Universidade de Constança na Alemanha. 
edifícios, leis, proposições filosóficas, entre outros, com função estratégica e inserida numa relação de poder. Conforme Agamben: "O dispositivo é qualquer coisa que tenha de algum modo a capacidade de capturar, orientar, determinar, interceptar, modelar, controlar e assegurar os gestos, as condutas, as opiniões e os discursos dos seres viventes." (2005 B, p. 40)

Desta maneira o autor compreende a fase extrema da consolidação capitalista que estamos vivendo como uma gigantesca acumulação e proliferação dos dispositivos. Como força adversa a tais capturas, Agamben propõe a profanação como possibilidade de ação em contradispositivo capaz de restituir ao uso comum aquilo que dele foi separado e dividido, de modo análogo, também o faz a identificação e reconhecimento da materialidade da casa-museu e sua avaliação enquanto testemunho da cidade, na tentativa de escapar ao caráter de ilustração do enredo ou de mera cenografia da vida privada. A contribuição do filósofo italiano na compreensão do que é o contemporâneo também é utilizada nesta pesquisa pelo protagonismo atribuido à percepção do que não está claro em nosso tempo, fenômeno corrente na casa-museu ao sobrepor categorias como enredo, mitificação, história editada à potência de seu testemunho material. 


\section{Os capítulos da tese}

Os capitulos da tese encadeiam-se de forma a apresentar casos selecionados para análise, permitindo debater diferentes feições relativas às casas-museu estudadas em cada um deles e as relações que suscitam e problematizam à luz de referenciais teóricos.

No primeiro capítulo, "Casa-museu: espaço e lugar", a relação entre Museu e coleção é transposta ao tipo específico avaliado na tese. O tema da relação entre a casa e a cidade é abordado pelo cotejo de atributos de casas-museu inglesas, francesas e japonesas em suas especificidades.

No segundo capítulo, "Enredos em disputa", a Casa-museu Magdalena e Gilberto Freyre, em Recife, PE, é citada à maneira de prólogo ao debate relativo às casas-museu em imóveis tombados. Apresento questões atinentes ao tombamento da Casa do Conselheiro Rodrigues Alves, em Guaratinguetá, SP, semelhante a outras situadas em núcleos urbanos de diferentes densidades e escalas, tombadas pelo Instituto do Patrimônio Histórico Nacional (IPHAN). Nesta investigação em particular, procuro debater a sobreposição de significados atribuídos às casas-museu, fundamentado nas categorias espaço e lugar. tendo como referencial teórico as asserções de Françoise Choay, a par das formuladas por Maria Lúcia Bressan Pinheiro e Maria de Lourdes Londres Fonseca, aliadas às premissas estabelecidas pelo Prof. Milton Santos e compreendendo o objeto da pesquisa como fato arquitetônico, na acepção de Bruno Zevi, em cooperação com as asserções de Michel de Certeau relativas ao espaço como efeito produzido pelas operações que o orientam, circunstanciam e temporalizam.

No terceiro capítulo, "Por um museu da casa", duas das casas-museu paulistanas, Casa Guilherme de Almeida, no bairro do Sumarezinho, e a sede da Fundação Maria Luísa e Oscar Americano, no Morumbi, são consideradas como documentos de extensa e complexa rede para relações na produção da cidade, dado material, arquitetônico e de articulação com o urbano, dado simbólico ${ }^{19}$, verificando como os processos de musealização destas casas, imbuídos da intenção de reiterar uma edição idealizada sobre a vida dos patronos, promovem o esquecimento ativo ${ }^{20}$ da arquitetura. $\bigcirc$ protagonismo do urbano, como categoria de pensamento da cidade, nas casas-museu pode

19. Henri Lefebvre conceitua a distinção entre cidade, categoria material, e urbano, como categoria de pensamento.(2016, p. 58)

20. Conceito proposto por Jean-Louis Déotte no âmbito de sua análise sobre as articulações entre esquecimento e a lembrança na formação de uma nação. 
ser observado nos dois casos, seja no bairro do Sumarezinho, no final dos anos 1940, e no Morumbi, no início dos 1950, inferindo a construção destas casas, seja durante a Ditadura Militar no Brasil, período em que foram musealizadas e abertas à visitação pública ${ }^{21}$. Nestes dois exemplos se enunciam relações com o tempo que serão tratadas no quarto capítulo.

Em "Arte contemporânea na casa-museu", quarto capítulo da tese, escala urbana e domesticidade são trabalhadas na zona de fronteira que se deseja estabelecer na conjunção entre casa-museu/arte/ tempo, como possibilidade de ativação das categorias intrínsecas à materialidade dos acervos, conflagrando temporalidades em fricção. Analiso as diversas relações com o tempo, presentes nestes exemplos, e suas especificidades enquanto tipologia museal, a colaborar com novas percepções e recepções da cidade e do urbano. A sede da Fundação Eva Klabin, no Rio de Janeiro, RJ, e a Casa de Vidro22, sede do Instituto Lina Bo e P.M. Bardi, em São Paulo, SP, são observadas, por incluir, de maneira mais ou menos sistemática, obras de arte contemporânea em suas programações temporárias. Amparo nos estudos de caso o debate sobre a arte site-specific em casas-museu.

Estudos de caso visam analisar distintas probabilidades nesse complexo conjunto e para propiciar novos trabalhos são aqui acompanhados de fichas que contêm informações e cotejamento de representações gráficas relativas à casa e à cidade em que se encontra; plantas da residência e da adaptação à função museal; e mapas de inserção na malha urbana nos dois tempos. Pretende-se que o conjunto de elementos observados no volume da investigação confirme a proposta defendida na tese sobre o interesse na constituição de rede representada por nova camada de observação ao conjunto de casas-museu existentes, qualificadas como fato arquitetônico.

21. A materialização de narrativas do poder instaurado, frequentemente durante regimes autoritários, apoia-se na construção de monumentos, na nomeação de obras de arte de engenharia, ruas e avenidas a citar, inclusive, a construção de memoriais e casas-museu No último período da Ditadura Militar brasileira (1964-1985), entretanto, embora tenham sido criadas, entre outras, estas duas casas-museu em São Paulo, não se musealizou casa de presidentes militares no Brasil, talvez por não haver entre eles nenhum natural do estado.

22. Originalmente Lina Bo Bardi denominava sua casa como Casa do Morumbi. A nomeação Casa de Vidro dada à residência da arquiteta foi posteriormente atribuída em uma exposição na FAUUSP, em 1989, pelos organizadores e assumida pela arquiteta a partir de então, segundo entrevista dada por Marcelo Ferraz à Tese de Doutorado de Maíra Teixeira apresentada à UnB (Pereira, 2014, p. 7). 



\section{CASA-MUSEU: ESPAÇO E LUGAR}

\section{Casa-museu, museu-casa}

Neste capítulo estabeleço alguns marcos com o intuito de balizar as questões debatidas nesta pesquisa, entre elas a relação entre casa- museu e cidade, iniciando por esclarecer a opção aqui adotada, pela locução casa-museu²3, em vez de museu-casa, sendo esta última de uso mais corrente no Brasil em denominações autoatribuídas pelas instituições, por títulos de encontros, congressos, publicações e trabalhos acadêmicos sobre o tema, de maneira a conferir-lhe precisão, desnaturalizando a constante variação a que esta denominação é submetida.

Admitindo que o desempenho em Museu24 possa ser visto como um processo, a acompanhar mutações no pensamento museológico que procuram alinhar práticas e procedimentos às expectativas de diversos públicos. Nesta investigação reconhece-se sua dimensão simbólica e condição de continuada transformação, e que a Casa ${ }^{25}$ é, neste caso, um dado permanente, item do acervo, que precedeu, prescinde e infere a ação museal a ela relacionada. Assim reconheço entre os dois substantivos, quando compostos, uma relação de qualificação expressa por Museu ao dispositivo ${ }^{26}$ Casa.

Casa-museu confere precisão à denominação das relações entre a Casa e os processos nela instaurados pelo Museu. Desta maneira, no plural casas-museu, varia somente o primeiro substantivo,

23. Casa-museu é comumente utilizada pelos autores lusófonos; casa-museo, por autores italianos; house-museum, pelos anglófonos; Hausmuseum, pelos alemães; e casa museo, pelos de língua espanhola, aproximando assim a opção adotada aos idiomas predominantes na bibliografia sobre o tema

24. Utilizo nesta pesquisa o Museu com a inicial maiúscula sempre que referente ao fenômeno de modo amplo, como forma de diferenciá-lo de suas manifestações em casos específicos

25. O substantivo Casa é utilizado aqui com letra maiúscula como forma de significar dimensões além da edificação em si correspondente a certo programa arquitetônico, a incluir seu entorno imediato, jardins e lote urbano.

26. Dispositivo a partir do debate proposto por Giorgio Agamben sobre a concepção do termo por Michel Foucault, como uma rede que se estabelece entre diversos elementos de um conjunto heterogêneo formado por discursos, instituições, edifícios, leis, proposições filosóficas etc., com função estratégica e inscrita numa relação de poder destinada a positivar a natureza das coisas. 
correspondendo entre o segundo e este uma relação de finalidade ${ }^{27}$ desafiada pela predominância da nomeação comumente utilizada no Brasil, que, embora não faça parte específica deste estudo, poderia sinalizar certa delimitação de área de atuação da disciplina Museologia.

\section{Museu e coleção}

Meses antes da recente chamada à Conferência Geral do ICOM 2019 (International Council of Museums), realizada em Kyoto, Japão, o comitê organizador convidou os membros a discutir e atualizar a definição de museu, por meio de um fórum na internet, propondo como reflexão o texto que reproduzo aqui:

\footnotetext{
Os museus são espaços democratizantes, inclusivos e polifônicos para um diálogo crítico sobre o passado e o futuro. Reconhecendo e enfrentando os conflitos e desafios do presente, eles guardam artefatos e espécimes para a sociedade, salvaguardam diversas memórias para as futuras gerações e garantem direitos iguais e acesso igual ao patrimônio para todos os povos

Os museus não são lucrativos. Eles são participativos e transparentes, e trabalham em colaboração ativa com e para várias comunidades, a fim de coletar, preservar, investigar, interpretar, expor e expandir os entendimentos do mundo, com o propósito de contribuir para a dignidade humana e justiça social, para igualdade mundial e bem-estar planetário.28
}

Esta proposta de definição alternativa foi colocada em votação na Conferência e até aquele momento não houve consenso sobre sua inclusão no Estatuto do ICOM, seguindo o recebimento de contribuições por meio de vários canais. A definição anterior, aprovada em 2007, que se pretende substituir, tem a seguinte redação:

\footnotetext{
Museu é uma instituição permanente, sem fins lucrativos, a serviço da sociedade e de seu desenvolvimento e aberto ao público que adquire, conserva, estuda, expõe e transmite o patrimônio material e imaterial da humanidade e do seu meio, com fins de estudo, educação e deleite. ${ }^{29}$
}

27. É consenso entre autores que se ocupam da gramática da língua portuguesa ser o substantivo composto formado por justaposição de radicais, a pressupor dominância conceitual, usualmente, o segundo substantivo qualifica o primeiro operando uma adjetivação, por exemplo: homem-rã, pedra-sabão. (Maria Helena de Moura Neves. Gramática dos Usos da Língua Portuguesa. São Paulo: Unesp, 2000.)

28. Conforme consulta em dezembro de 2019 pelo link: http://www.icom.org.br/?p=1863

29. Trecho da definição de museu do Conselho Internacional de Museus (ICOM) em 2007. Disponível em http://icom-portugal.org/2015/03/19/definição de museu/> Acesso em 12/07/2016 
Recente encontro promovido pelo ICOM Brasil, em São Paulo ${ }^{30}$, destinado a colher uma sugestão à proposta de definição, mostrou a preocupação dos seus membros tanto com a questão formal como de conteúdo que ela contém. Historicamente as definições de museu do ICOM têm sido importante instrumento de orientação da política museal em muitos dos países-membros, por oferecer, entre outras possibilidades, um eficiente instrumento de afirmação e negociação dos museus com os governos. A definição vem sendo alterada ao longo dos encontros do ICOM, sinalizando e acompanhando modificações vivenciadas pelo setor, frequentemente por meio da introdução de um ou outro termo, entretanto, esta, apresentada meses antes da Conferência de Kyoto, propõe texto que se aproximaria de uma missão, ao se compor de dois parágrafos que praticamente abandonam os termos utilizados anteriormente e introduzem conceitos polêmicos e de complexa operação a nível mundial, considerando que são centenas de países membros, com realidades muito diversas. ${ }^{31}$

Embora associado ao espaço da antiguidade em Alexandria, por Denis Diderot (Schaer, 1993), o museu como instituição ocidental contemporânea tem seu início creditado por vários autores ${ }^{32}$ na passagem dos gabinetes de curiosidades da Idade Média para a instituição fundada na Universidade de Oxford, a partir da coleção de Elias Ashmole. No texto "El hombre sin contenido" (2005), Giorgio Agamben afirma que na Wunderkammer (câmara das maravilhas) parece reinar a desordem, mas não se trata de um caos, pois "[...] para a mentalidade medieval era uma espécie de microcosmo animal e vegetal"33, associando a passagem da Wunderkammer medieval para os museus modernos à aparição do homem de bom gosto que marcou o ingresso da obra de arte no terreno da estética. Agamben busca reconhecer no espaço do museu um sinal do momento em que a arte se constituiu como esfera autônoma, com identidade específica, transformada em objeto de coleção, estabelecendo, assim, distância em relação às outras coisas, afirmando sua retirada do espaço comum a todos os homens.

30. O encontro promovido pelo ICOM se deu em 15/10/2019, na Japan House, em São Paulo, SP, com a presença do então presidente do Instituto Brasileiro de Museus (IBRAM), Paulo Amaral, da presidente do ICOM Brasil, Renata Vieira da Motta, e de Carlos Brandão, membro do comitê executivo do ICOM, além de representantes brasileiros nos diversos comitês específicos da instituição como o Icofom - museologia, Ceca - educação.

31. Na reunião extraordinária convocada para votação da definição durante a Conferência de Kyoto, a intervenção da representante do Irã externou sua preocupação em ter que apresentar aos dirigentes do governo daquele país uma definição institucional que contém o termo democratizante.

32. Georges Henri Riviére e Roland Schaer, entre outros.

33. "Mas o caos que parece reinar na Wunderkammer é apenas aparente: para a mentalidade do sábio medieval, era uma espécie de microcosmos, em seu fantasma harmonioso, o macrocosmo animal, vegetal e mineral." (Agamben, 2005 A, p. 54, tradução nossa). 
Roland Schaer atesta a criação do Museu dos Monumentos Franceses, por Alexandre Lenoir, no período posterior à Revolução Francesa, paralelamente à apropriação dos chamados bens nacionais, a uma reação ao desejo de afrontar a antiga monarquia. Assim afirma que os objetos, ao serem recolhidos ao museu, que era um espaço neutro ${ }^{34}$, faziam esquecer (faisse oublier) sua significação religiosa, monárquica ou feudal.

O Museu, desde sua gênese, foi uma ocupação amigável para prédios históricos, segundo Ayşen Savaş35. Para a pesquisadora, à medida que os museus passaram a demandar certos parâmetros relativos à preservação e exposição de suas coleções, pesquisadores e visitantes também aumentaram suas exigências. As novas regras edilícias contemporâneas tornaram obrigatórios elevadores, saídas de emergência e outras facilidades que precisam de espaço, incluindo outras necessidades como cafés, lojas, bibliotecas, auditórios, etc. tornando os edifícios históricos inadequados e vulneráveis, obrigando os museus a construírem anexos ou mesmo novos edifícios para viabilizar suas atividades. E a casa-museu? Como enfrentar esta realidade num edifício que é acervo?36

A conexão entre Museu e Coleção, reconhecida por diversos autores, é abordada de forma essencial por Aurora León37, ao afirmar que, embora o Museu opere uma mutação qualitativa fundamental no objeto ao retirá-lo de seu uso, não desqualifica sua validade objetiva como produto útil e submetido a mudanças históricas.

Walter Benjamin, ao reconhecer como decisivo na coleção o desligamento de todas as suas funções primitivas, identifica a nova relação em que se insere o objeto de coleção como de completude, termo definido pelo autor como:

34. A neutralidade citada por Schaer foi, em tempos de convulsão, uma narrativa oportuna encontrada por Alexandre Lenoir na promoção da salvaguarda dos testemunhos do Ancien Régime, que de outro modo haveria, como tantos, desaparecido. A revisão do termo neutralidade no espaço museal é contestada e analisada em trabalhos de autores ligados à Nova Museologia, como Charles Summarez Smith, quando da edição por Peter Vergo do livro New Museology, em 1989, editado pela Reaktion Books, no Reino Unido.

35. Ayşen Savaş é professora associada na Faculdade de Arquitetura da METU (Midle East Technical University), na Turquia, e esteve no Brasil como professora no curso oferecido pelo Demhist de capacitação de pessoal para casas-museu.

36. É esta a alternativa usada na Casa de Rui Barbosa, no Rio de Janeiro, e de forma análoga na Casa do poeta José Régio, em Vila Nova do Conde, Portugal. No Rio de Janeiro, a construção de um edifício nos fundos do terreno da antiga chácara no bairro de Botafogo possibilitou a instalação de biblioteca, auditório e áreas administrativas da Fundação Casa de Rui Barbosa. Já na casa do poeta português, a aquisição de uma residência próxima propiciou a reedição dos espaços domésticos da residência e na casa nova foram instalados o centro de documentação, auditório e áreas administrativas.

37. Aurora León Alonso (1948-1999), professora de História da Arte na Universidade de Sevilla, autora do livro El Museo: teoria, práxis, utopia. Madri: Ed. Cátedra, 1990. 
[...] uma grandiosa tentativa de superar o caráter totalmente irracional de sua mera existência através da integração em um sistema histórico novo, criado especialmente para este fim: a coleção. (2009, p. 239)

Benjamin afirma que "[...] o verdadeiro método de tornar as coisas presentes é representá-las em nosso espaço (e não nos representar no espaço delas)" (2009, p. 240), opondo ao colecionador o homem chamado profano e comparando a coleção ao dicionário em sua relação com uma ordem natural. O sagrado e o profano protagonizam vários textos relacionados aos museus, sendo o sagrado, aquilo que é separado, transposto a uma nova ordem, e profano, o do mundo comum, do ordinário.

Giorgio Agamben estende e aprofunda o termo Museu em texto recente, associando-o a uma dimensão separada "[...] à qual se transfere o que em um tempo era sentido como verdadeiro e decisivo, e agora já não é" (2007, p. 73), cita o Museu também como cidades inteiras (Veneza, Évora) ${ }^{38}$, regiões ou parques, dos quais temos vários em território brasileiro ${ }^{39}$, e grupos de indivíduos ou formas de vida que desapareceram. $\bigcirc$ autor afirma que "[...] de forma mais geral, tudo pode tornar-se Museu, na medida em que esse termo indica simplesmente a exposição de uma impossibilidade de usar, de habitar, de fazer experiência." (2007, p. 73).

A lucidez do filósofo italiano sobre o tema é lançada sobre o fenômeno ligado à explosão das instituições museais que se dá desde o final do século XX em diante no ocidente, objeto de estudo de Andreas Huyssen ${ }^{40}$, entre outros, que considera suas razões como reação à compressão do espaço-tempo operada pela pós-modernidade.

Huyssen, em 2000, se baliza no argumento de filósofos alemães conservadores ${ }^{41}$ que descrevem, na década de 1980, a musealização como central para o deslocamento da sensibilidade temporal do nosso tempo afirmando que a musealização não era mais privilégio

38. A incluir Paraty, Tiradentes e outras cidades brasileiras do período colonial, cujas políticas de preservação não contemplam a população e suas práticas sociais vigentes para além dos edifícios e traçados urbanos, de modo que se apartam de seu uso como os objetos museais.

39. Notável é o ocorrido em territórios das reservas indígenas, cujas dilapidações sistemáticas têm sido operadas desde o momento mesmo em que foram estabelecidas, intensificando-se por meio de recentes políticas públicas que desfavorecem a representação de minorias étnicas.

40. Andreas Huyssen (1942) é professor de língua alemã e literatura comparada na Universidade de Columbia, autor de Seduzidos pela memória: arquiteturas, monumentos, mídia (2000) e Culturas do passado-presente: modernismos, artes visuais, políticas da memória (2014). 
da instituição museu, mas havia se infiltrado na vida cotidiana, resultando desta convicção seu diagnóstico:

[...] precisa-se da memória e da musealização, juntas, para construir uma proteção contra a obsolescência e o desaparecimento, para combater a nossa profunda ansiedade com a velocidade de mudança e o contínuo encolhimento dos horizontes de tempo e de espaço. (2000, p. 28)

Em texto recente ${ }^{42}$, o autor aprofunda sua análise do que chama o impasse da memória, visto por ele como um embate travado entre a memorialização e o esquecimento na perspectiva de uma traição dupla ao passado e ao presente, na comparação que faz entre o memorial do World Trade Center, em Nova Iorque, em homenagem aos mortos no atentado de 11 de setembro de 2001, projetado por Michael Arad e Peter Walker, e o Monumento aos Judeus Assassinados da Europa, em Berlim, projetado por Peter Eisenman.

Museu e coleção estão intrinsecamente ligados, como afirma o seminal texto de Krzysztof Pomian ${ }^{43}$, sobre as oferendas colocadas nos templos em que afirma:

[...] ainda que sejam intermediárias entre o mundo de cá de baixo e o do além, entre o profano e o sagrado, as oferendas podem ser, no mundo profano, objetos que representam o longínquo, o oculto, o ausente. Noutros termos são intermediárias entre o espectador que as olha e o invisível de onde veem. (1984, p. 64)

Pomian amplia a compreensão da potência do objeto em coleção, para conexão com o invisível, o que já não está mais lá, fundamentando a operação envolvida na ação dos museus, dada a representação social que adquiriram na atualidade, substitutos dos templos como espaços de concepção e reprodução de valores éticos para além dos estéticos.

A analogia entre sacrifício e a operação de introdução dos objetos em uma coleção torna-se possível ao ser qualificada por Agamben como um dispositivo que estabelece a passagem de algo profano para o sagrado e, na musealização, opera-se no sentido de subtrair os objetos do livre uso e comércio dos homens.

42. "A cultura da memória em um impasse: memoriais em Berlim e em Nova Iorque" in: Culturas do passado-presente: modernismos, artes visuais, políticas da memória. Rio de Janeiro: Contraponto. 2015, p. 139-152.

43. Krzysztof Pomian (1934), filósofo, historiador e ensaísta, diretor acadêmico do Museu da Europa em Bruxelas. 
Ao se investigar a similaridade entre duas situações, é admissível caracterizar algumas entre tantas ações dos museus contemporâneos: a primeira delas seria, conforme descrita pelo autor italiano, a promiscuidade entre as duas operações no sacrifício romano, no qual uma parte da própria vítima consagrada acaba profanada por contágio ao ser consumida pelos homens, enquanto outra é entregue aos deuses; a segunda circunstância seria a condição do objeto de coleção contemporâneo articulado entre Museu e Mercado. Atesta a referida contaminação a representação dos colecionadores privados na composição dos conselhos dos museus de arte públicos, fenômeno observado em todo o Ocidente capitalista. $\bigcirc$ papel de salvaguardar o capital simbólico e a participação na pré-formação da consciência social das comunidades assumido pelos museus na atualidade se vê ameaçado, no caso dos museus de arte de maneira mais expressiva pelo referido processo de composição de seus conselhos. ${ }^{44}$

De acordo com Walter Benjamin, o sentido subjetivo do colecionador teria se transformado em mercadoria (2009, p. 241). Este fenômeno é relacionado por León ao tempo em que a coleção se torna indicador de riqueza e diferença social e o colecionismo toma corpo de autêntico mercado ampliando, segundo a autora, definitivamente seu conceito: a coleção como inversão de capital. León associa a Marco Agripa ${ }^{45}$, em Roma, a "[...] primeira declaração explícita do valor de uma coleção como patrimônio cultural de todos." (1990, p. 19).

Pomian, ao final de seu texto "Coleções" afirma: "[...] ao colocar objetos nos museus expõem-se ao olhar não só do presente, mas também das gerações futuras, como dantes se expunham outros aos deuses." (1984, p. 84). A utilização de termos, como democratizantes, inclusivos ou dignidade humana, na definição alternativa proposta em 2019 pelo ICOM, parece procurar nortear o papel das instituições que representa como espaços de resistência, embora possa revelar, como paradoxalmente cogitado por Agamben, uma lista de impossibilidades contemporâneas que se abrigariam nesta separada dimensão a que chamamos Museu.

44. O debate sobre este tema tem sido objeto de discussão em grupos acadêmicos e tem tido veiculação na imprensa conforme atesta a recente artigo publicado pelo jornal estadunidense New York Times, em crítica à composição do conselho do Museu de Arte Moderna de Nova Iorque. Disponivel em: <https://www1.folha.uol.com.br/ilustrissima/2020/01/ como-os-super-ricos-assumiram-o-controle-do-mundo-dos-museus.shtml>. Acesso em: 2/02/2020. Outro artigo no mesmo jornal, comenta a situação nos museus brasileiros de processos similares. Disponivel em: https://www1.folha.uol.com.br/amp/ilustrissima/2020/01/ecossistema-das-artes-merece-as-vaias-que-recebe.shtml. Acesso em: 2/02/2020.

45. Marco Vispânio Agripa (62 - 12 a.C.), cônsul romano. 
Embora a Museologia como apontada por León, entre outros autores, em sua gênese, enseje a abolição das fronteiras sociais e o livre e voluntário acesso de toda a sociedade ao Museu, a autora reconhece que este surge a partir das coleções reais e aristocráticas cujo acesso público se deu a partir do século XVI apenas.

[...] partimos de un hecho: aristocracia e burguesía son las que han permitido la creación del museo que hoy visitamos, un museo actual que, lejos de caracterizarse por una nivelación social y una participación colectiva, sigue siendo el coto cerrado de una clase privilegiada (ampliada con el capitalismo contemporáneo) que en un modo o en otro obstaculiza a muchos el acceso a la cultura. ${ }^{46}$ (1990, p. 54)

Museu se apresenta então, no trabalho de Aurora León, como espaço destinado à mediação entre homem e objeto, coletando, identificando, catalogando, preservando e exibindo. Mas é ainda muitas vezes reconhecido no Brasil ${ }^{47}$ como espaço intelectualizado, elitizado, sem conexão com a vida cotidiana das pessoas, fato que a afirmação de León talvez nos ajude a compreender.

O papel dos museus vem se modificando ao longo do tempo à medida que assumiram protagonismo, outrora atribuído aos templos, na salvaguarda ${ }^{48}$ de capitais simbólicos referentes às comunidades em que estão inseridos. Hoje, a aceleração do tempo e o crescente processo de urbanização a que estamos submetidos, aliados à mobilidade das populações, produtos, imagens e ideias, possibilitados pela difusão de novas tecnologias, têm sido responsabilizados por diversos

46. "[...] Partimos de um fato: foram aristocracia e burguesia que permitiram a criação do museu que hoje visitamos, um museu atual que, longe de se caracterizar por um nivelamento social e uma participação coletiva, segue sendo a reserva fechada de uma classe privilegiada (ampliada com o capitalismo contemporâneo) que de uma forma ou de outra dificulta o acesso à cultura a muitos." (tradução nossa).

47. Entre outras a pesquisa intitulada $\bigcirc$ "não público" dos museus: levantamento estatístico sobre o "não ir" a museus no Distrito Federal, feita pela Coordenação de Pesquisa em Processo Museal do Departamento de Museus do Instituto Brasileiro de Museus CPIM/ DEPMUS/IBRAM, em 2012, identificou que 77\% da população do Distrito Federal nunca havia ido a um museu e detectou esta parcela de cidadão como de renda e escolaridade mais baixa. O resultado da pesquisa sugere "[...] políticas públicas macrossociais como aumento da escolarização e renda de segmentos sociais subalternos, devem ser concomitantes com ações em nível microssocial, como por exemplo, programas de integração entre escolas e museus para poderem ter o efeito de fornecer os recursos simbólicos necessários para a fruição de bens culturaismusealizados". Disponível em: <https://www. museus.gov.br/wp-content/uploads/2013/09/naopublico.pdf>. Acesso em: 16/01/2019.

48. De acordo com a Recomendação de Nairóbi de novembro de 1976, a Unesco entende salvaguarda como "a identificação, a proteção, a conservação, o restauro, a reabilitação, a manutenção e a revitalização dos conjuntos históricos, e do seu enquadramento.". Incluindo entre os conjuntos históricos os edifícios isolados com importância histórica e/ou arquitetônica para as comunidades. 
autores $^{49}$ como motivadores de processos de desterritorialização e desculturação, que operariam radical alienação do homem urbano, a demandar dos museus novas articulações em diálogo com a cidade. Ocorre observar de que maneira certos tipos de instituições e equipamentos culturais voltados à preservação de memórias, no Brasil e em outros países, vêm pautando suas práticas em relações e procedimentos anacrônicos, aderidas a conceitos que reproduzem modos de visualização do passado, incapazes de realizar suas potencialidades na construção de relacionamentos com distintos segmentos em comunicação e trocas. A casa-museu, nesta visada, tem atributos específicos que podem tornar esta conexão possível.

\section{Casas-museu e cidades}

Transpostas estas considerações iniciais ao tipo específico de Museu de que trata esta pesquisa, nascido também como continente de coleções, as casas-museu aparecem no Ocidente, da forma como hoje as reconhecemos, por meio da preservação da residência do professor da Royal Academy de Londres, Sir John Soane ${ }^{50}$, cujos propósitos eram inicialmente acadêmicos. Sir John Soane preencheu sua casa, mais duas vizinhas que anexou entre 1796 e 1837, com sua extensa coleção composta por fragmentos arquitetônicos, maquetes, desenhos, pinturas e objetos, organizados de maneira aproximada à Wunderkammer ${ }^{51}$, como um instrumento de apoio didático a sua função no curso de Arquitetura, e mantinha, também, nestes espaços que eram interligados, seu gabinete de trabalho, no qual concebeu e detalhou inúmeras obras do chamado período georgiano ${ }^{52}$, a maioria delas em Londres. O Sir John Soane's Museum foi tornado público por ato do parlamento, em 1833, preocupado que estava o professor com a autonomia financeira e continuidade de sua iniciativa.

49. Milton Santos, Henri Lefebvre e Néstor Canclini, entre outros.

50. Em dissertação de mestrado que apresentei à FAUUSP, em 2013, o Capítulo III, "Casa-museu horizonte de expectativas", inclui extensa descrição desta instituição londrina.

51. No final do século XVI, na Europa, se difunde, segundo Roland Schaer, "[...] uma outra forma de coleção: o gabinete de curiosidades, chamado nos países germânicos de Kunst und Wunderkammer. O modelo organiza junto com antiguidades e peças históricas novos tipos de objetos: curiosidades naturais ou artificiais e raridades exóticas." (1993, p, 21)

52. No período georgiano da Arquitetura Britânica, descrito por John Summerson entre 1720 e 1840, predominou a produção de edifícios públicos e privados nas Ilhas Britânicas e em suas colônias: Estados Unidos, Canadá, marcados por uma estrutura de base clássica e bastante simétrica adornada por ornamentos provindos de períodos anteriores como o rococó, o neoclassicismo e o paladiano (Summerson, 1953). 
Fig. 1 - Sir John Soane's Museum, Londres, Reino Unido. Fachada. 2012. Foto A

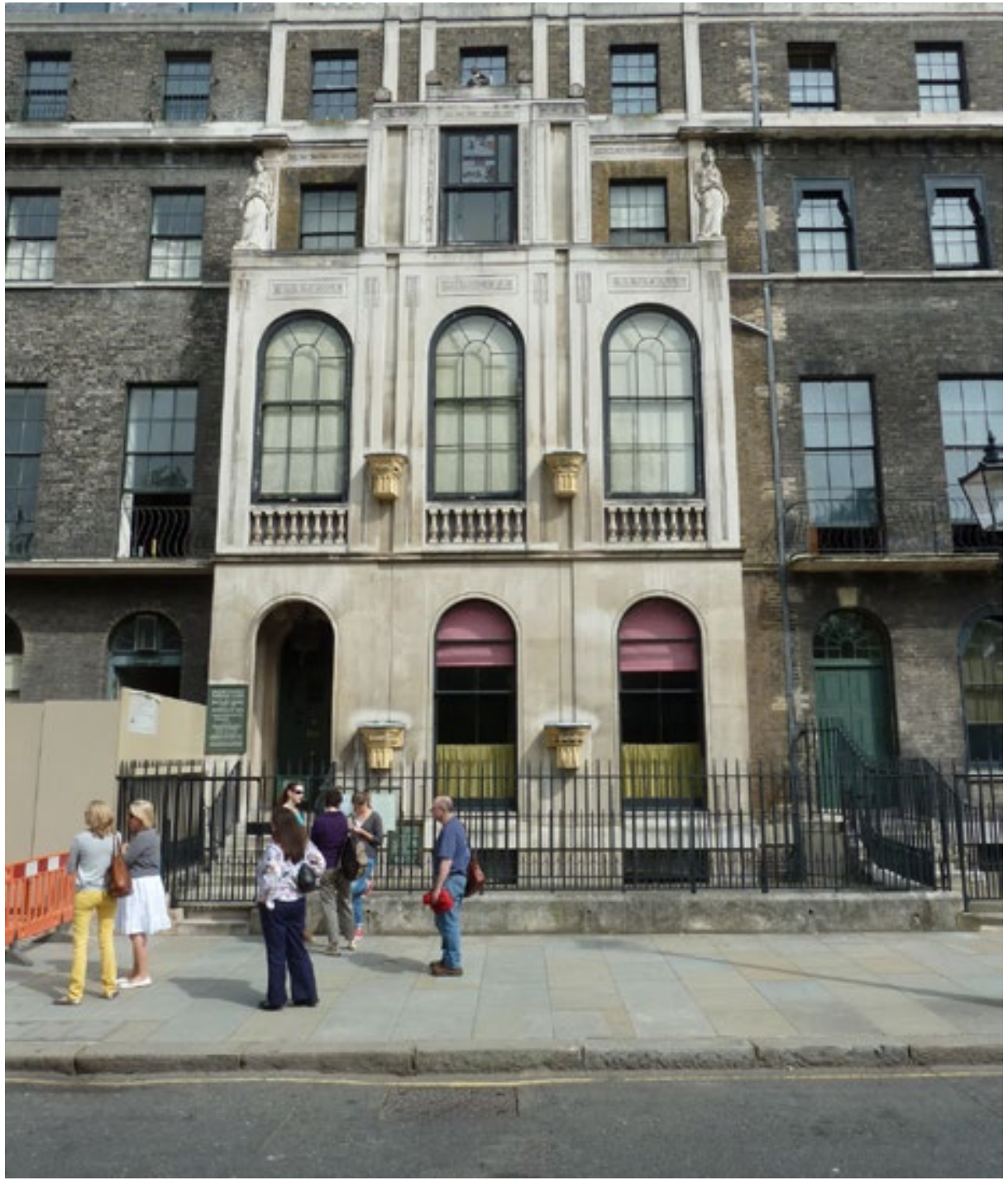

Embora o Sir John Soane's Museum surja até o momento como provável primeira casa-museu ocidental, seu estatuto de fundação é de curiosa exemplaridade, estabeleceu gestão submetida a consetho curador, formado por instituições que deveriam designar seus membros por prazo determinado. Seu propósito acadêmico paulatinamente deu lugar a outras funções, por sua longevidade. Reconstituíram-se áreas íntimas e de serviço da residência, conforme estavam na passagem do século XVIII para o XIX, tendo por base os desenhos dos alunos de Soane, dado o crescente interesse no modo de vida que se sobrepôs aos propósitos iniciais. A relação entre esta peculiar edificação e as mudanças da cidade de Londres pode ser atestada nos inúmeros mapas e documentos do seu acervo. Como todas as casas-museu existentes, concebida inicialmente como residência e posteriormente transformada em museu, a especificidade de suas coleções, em que se encontram testemunhos do crescimento urbano de Londres, objeto de trabalho do patrono, revelam o desenvolvimento da cidade. 
Sir John Soane inaugurou, ao final do século XVIII, a casa tornada museu por intenção de seu proprietário, empreitada frequente nas casas-museu de colecionadores. Se podemos observar na criação das casas-museu, ao longo dos últimos séculos, a predominância do intuito de homenagear personagens, os chamados patronos, estas casas são inegavelmente expressão material e imaterial de um urbano que as constrói e ajudaram a construir. Seja nos materiais e técnicas, na distribuição dos espaços e funções, seja em sua escala e proporções, na ocupação no lote, em sua relação com o entorno imediato, com o bairro e identificada com a cidade.

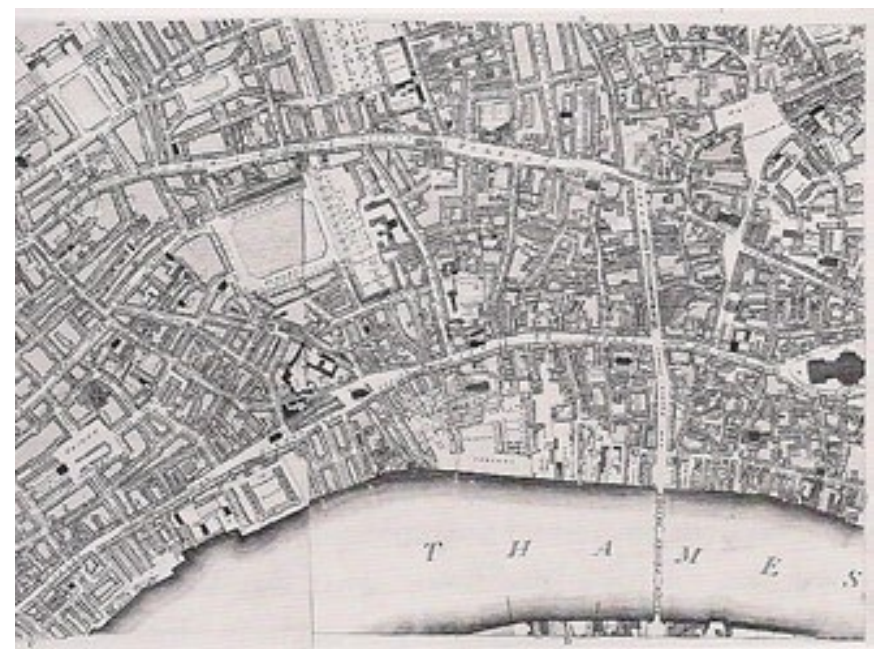

É evidente, na visita à casa de Honoré de Balzac ${ }^{53}$, em Paris, a possibilidade de entendimento da cidade que se abre a partir da observação dos dois tempos deste museu que homenageia o autor francês. A casa situa-se no XVIéme que, à época, era um arrabalde malcheiroso à beira do Sena, quando Balzac alugou parte deste imóvel e nele habitou por muitos anos, escrevendo sobre a cidade de Paris e suas transformações. O museu, intitulado Maison de Balzac, hoje ocupa área bem maior do que originalmente a casa de seu homenageado, e seu entorno tornou-se a partir dos anos
Fig. 2 - Mapa de Lincoln Inn Fields, Londres, Reino Unido. 1799 Arquivo Sir John Soane's Museum.

53.Visita técnica, efetuada em 26/12/2013, em que entrevistei o diretor do museu, Yves Gagneux. Sua explanação sobre a ação do museu incluiu uma descrição detalhada dos espaços originais ocupados pelo escritor francês e os que foram sendo incorporados pelo museu ao longo do tempo. 
Fig. 3 - Maison de Balzac, Paris, França. 2016. Foto A.

Fig. 4 - Maison Victor Hugo, Paris, França. 2016. Foto A.

1950, principalmente, um dos bairros mais sofisticados da capital ${ }^{54}$. O ofício museológico é centrado na divulgação da obra do escritor e na produção de pensamento acerca dela, por meio da promoção de cursos, conferências e reedições críticas.
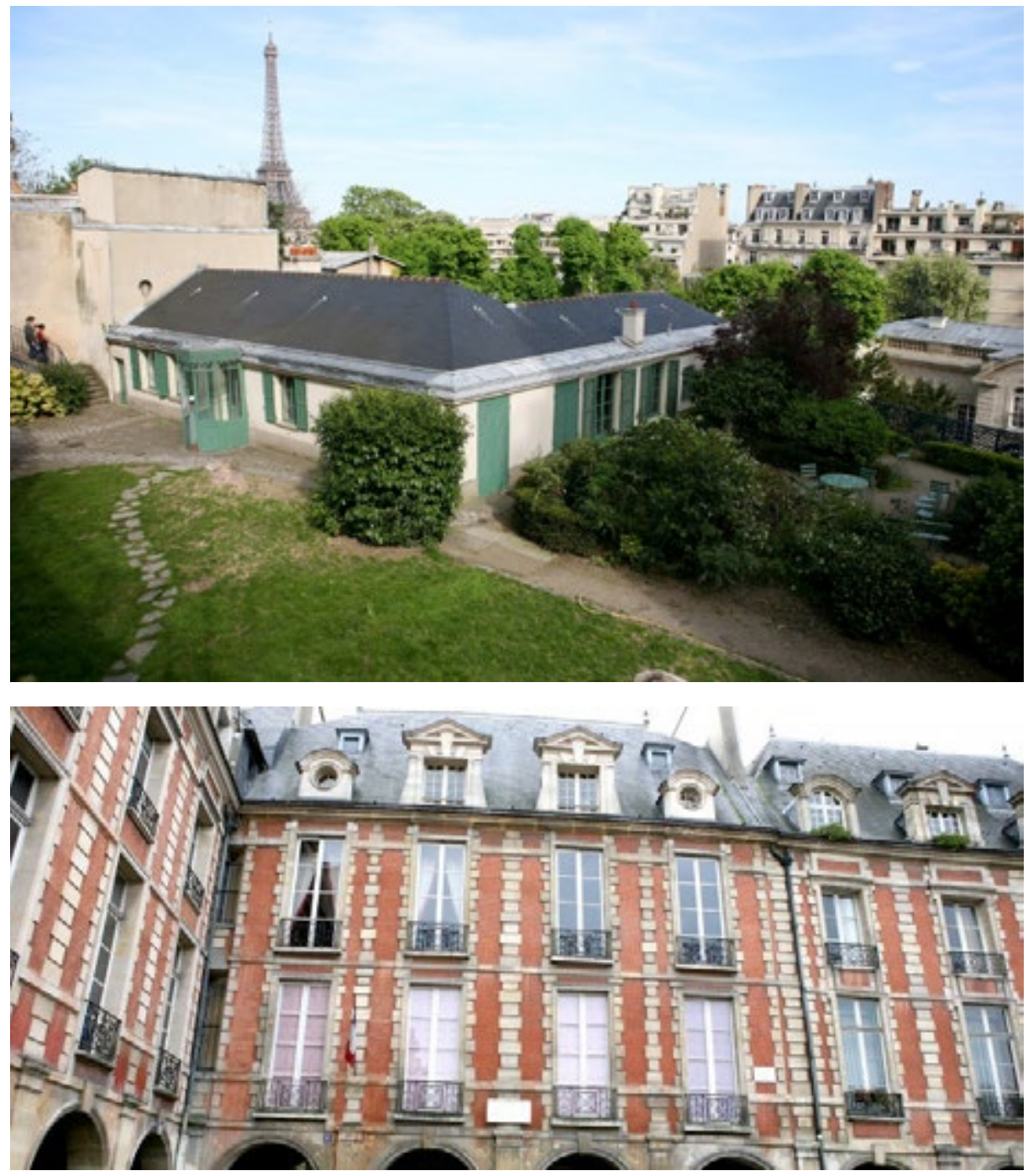

54. Há que se observar a intensa relação entre Museu e gentrificação nas cidades contemporâneas, marcada pela expulsão das populações autóctones, que em princípio deveriam ser o foco principal de trabalhos de requalificação urbana instrumentados pela implantação de museus em áreas degradadas nas regiões centrais das grandes cidades, por força de sua valorização financeira. Em São Paulo, o projeto Luz Cultural norteou a criação da Sala São Paulo, articulada com a Pinacoteca do Estado de São Paulo e o Museu da Língua Portuguesa, na Estação da Luz. Estas instituições desenvolvem programas de inserção da população do entorno, cujo alcance, de maneira isolada, não têm conseguido fazer diferença significativa, na medida em que poder público, comerciantes, e pessoas em situações de vulnerabilidades atuam em violento jogo de tensões no bairro reforçando o defendido nesta tese de que há uma lacuna a ser preenchida pelos trabalhos focados na sedimentação e fortalecimento de identidades em busca de resistir aos processos de alienação urbana. 
Na mesma cidade, a Maison Victor Hugo ${ }^{55}$, situada num dos vértices da Place des Vosges, no bairro do Marais, também não corresponde exatamente aos ambientes habitados pelo escritor, mas se instala atualmente em área muito maior por meio da anexação de espaços contíguos, procura relacionar sua obra a outras vertentes das artes como pintura, escultura e teatro. Desta maneira, essas casas parisienses ocupam um certo lugar dos homenageados, conquanto não se interessem pela reprodução do ambiente doméstico, mas sim, numa ação ampliada que leva em conta de maneira preponderante o locus. Há evidente prioridade dada à relação entre a memória e o lugar antropológico, no sentido histórico, relacional e identitário (Augé, 1994, p. 73).

Diferentemente das casas de Balzac e Hugo, casas-museu de personagens abastados, como o Musée Jacqmart-André56e o Musée Nissim de Camondo ${ }^{57}$, se alojam, também em Paris, em Hôtels Particuliers, imóveis de grandes dimensões construídos na virada do século XVIII para o XIX, mantidos em toda sua arquitetura, jardins, mobiliário e decoração da maneira determinada em testamento por seus proprietários, imbuídos, como em muitos casos, pela fantasia da permanência de sua memória nas coleções. A seu modo, também testemunham em seus dois tempos, de residência a museu, uma cidade tornada possivel pela concentração de capital da burguesia do século XIX. A construção destas duas residências burguesas em Paris se insere no plano de reforma da cidade de Paris, promovida pelo Barão Haussmann no século XIX.

55.Visita técnica, efetuada em 27/12/2013, em que entrevistei o diretor do museu, Gérard Audinet. $\bigcirc$ depoimento versou sobre a atuação da Maison Victor Hugo na difusão do pensamento do autor focada na relação entre este e outras formas artísticas. Naquele período o museu apresentava a exposição La Cime du Rêve ( $O$ cume do sonho), justapondo de maneira inédita cerca de 50 desenhos de Hugo e grandes obras de Max Ernst André Masson, Yves Tanguy, Francis Picabia, René Magritte e outros expoentes do movimento surrealista.

56. Visita técnica, efetuada em 29/12/2013, em que entrevistei o conservador do museu, Pierre-Nicolas Sainte Fare Garnot. O conservador falou sobre entre outros tópicos da história da formação do museu e de sua especial situação no terreno que permitiu a preservação da fachada principal que se encontra voltada para o Parque, em detrimento da fachada secundária que é lindeira ao Boulevard Haussmann.

57. Visita técnica, efetuada em 30/12/2013, em que entrevistei a conservadora do museu, Sylvie Legrand-Rossi, que me descreveu as ações de pesquisa e projeto que culminaram na restauração da área de cozinha e empregados do museu. 
Fig. 5 - Museé Jacqmart-André, Paris, França. 2016. Foto A.

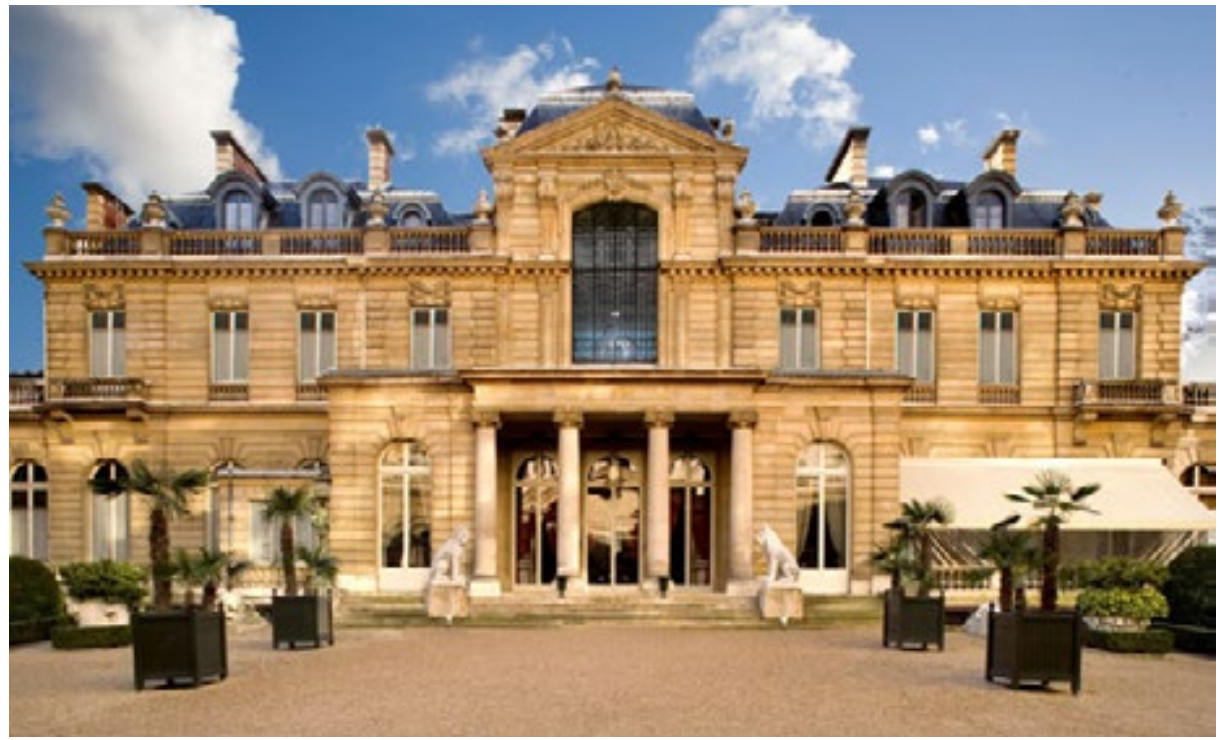

Fig. 6 - Museé Nissim de Camondo, Paris, França. 2016. Foto A.

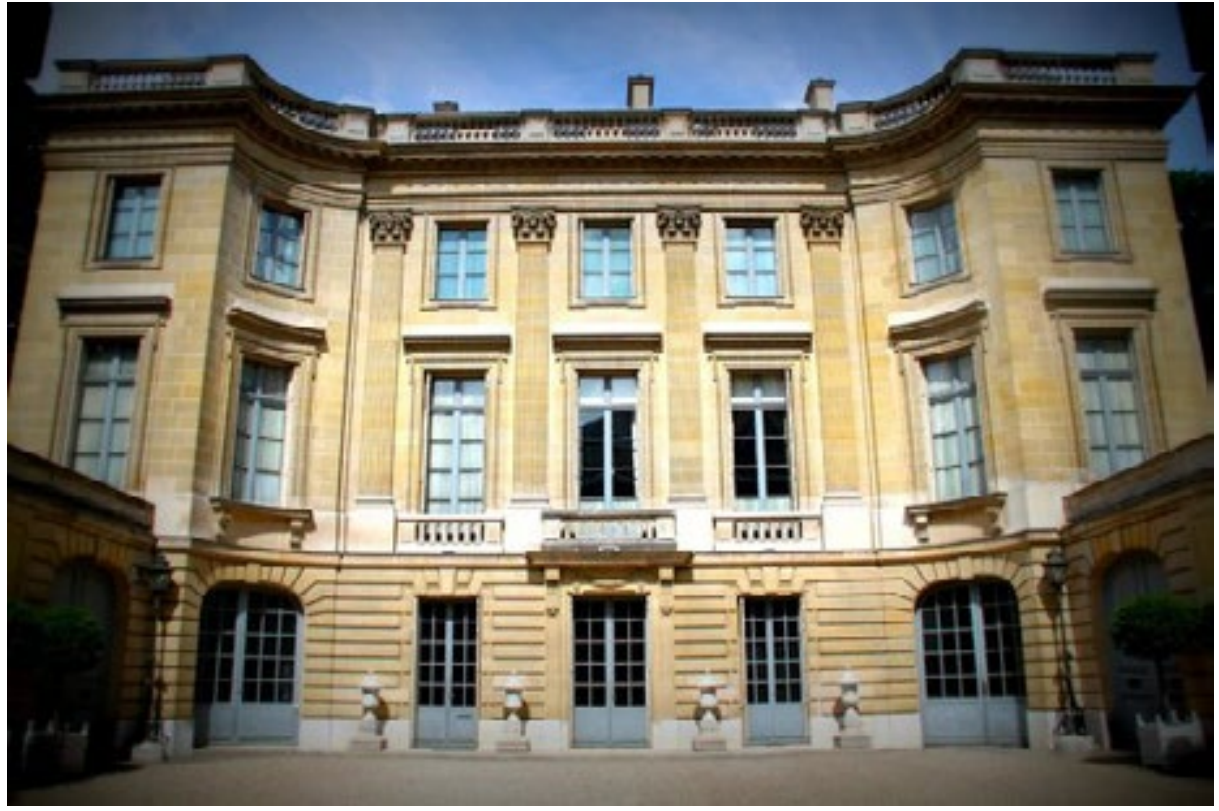

Casas-museu japonesas ${ }^{58}$, visitadas durante esta pesquisa, exploram em sua expografia, sua relação com as cidades em que estão inseridas por meio de elementos gráficos e maquetes. Em Kanazawa, as casas-museu Nishi Chaya Shiryokan Museum e Muro Saisei Kinenkan Museum e, em Kyoto, Kawai Kanjiro Memorial Museum, atestam diversidade no modo de vida oriental expresso no espaço doméstico e na sua musealização. Todas as casas-museu japonesas visitadas são geridas por familiares dos homenageados e exprimem uma motivação centrada no lugar, na posição na cidade. 


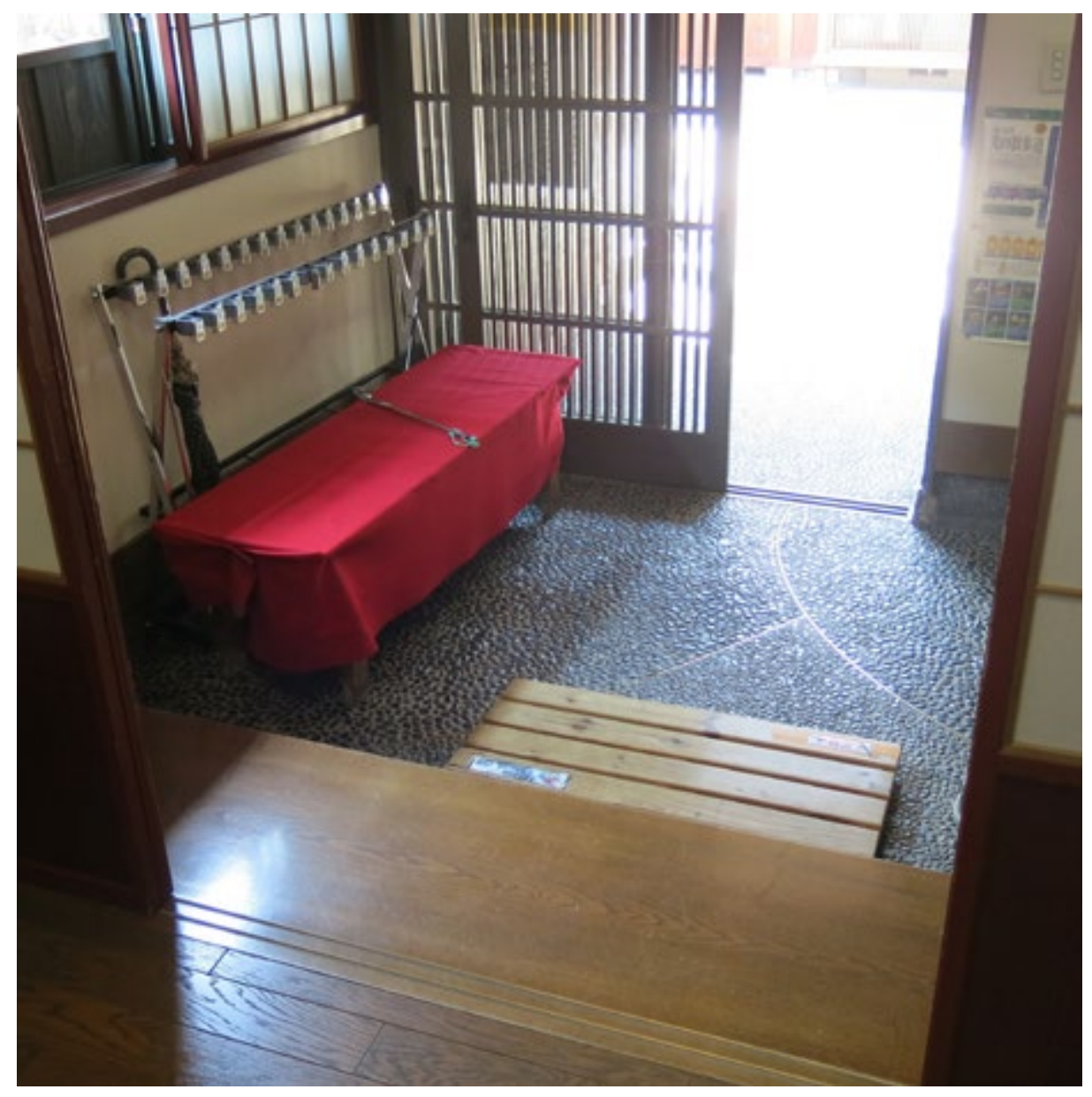

Fig. 7 - Nishi Chaya Shiryokan Museum, Kanazawa, Japão. Genkan. 2019 Foto A.

Característica específica da casa tradicional japonesa, a espacialidade $\mathrm{Ma}^{59}$, expressa-se de forma simplificada no genkan ${ }^{60}$, espaço de transição entre a cidade e a casa, tendo seu piso frequentemente revestido com o mesmo material do exterior, que possibilita o recuo abrigado na mesma cota de nível da rua. Uma pequena elevação diferencia o espaço interno da casa, que deve ser acessado sem os sapatos. "Não há uma delimitação nem uma função preestabelecida para o espaço privado na arquitetura residencial tradicional japonesa" (Okano, 2012, p. 82). Os espaços internos da casa tradicional japonesa têm sua função definida pelo mobiliário, que é sempre passível de ser guardado para que outra função se estabeleça no mesmo local. Assim o mesmo lugar pode ser usado como quarto, sala ou eventualmente local de cozinhar. Esta prática cotidiana do espaço tradicional japonês soma-se à concepção de origem budista que privilegia a permanência da forma à materialidade. "O dilema ocidental, conservar ou restaurar não existe" (Hartog, 2006, p. 267). A lógica é a da atualização.

59. "Ma é uma noção que não faz parte da lógica linear ocidental, mas daquela coordenada por relações: ele não se apresenta como conceito, porém como um modus operandi vivo no cotidiano dos japoneses. Presente em todas as manifestações culturais japonesas, - Ma possui múltiplas semânticas: uma delas é a do espaço de possibilidade e outra é a de espaços intervalares, que desconstrói o pensamento dual e aposta na possiblidade de um espaço que pode ser concomitantemente as duas coisas." (Okano, 2012, p. 1).

60. Hall de entrada da residência tradicional japonesa. 
Fig. $8-$

Muro Saisei Kinenkan Museum, Kanazawa, Japão. Fachada. 2019. Foto A.
Assim, em contraposição à noção de patrimônio ocidental em que protagonizam as noções de original, cópia, autenticidade, impondo circunstâncias específicas à preservação, templos, casas e outros exemplares da arquitetura nipônica são desmontados e remontados periodicamente. Concorrem técnica construtiva e ritualização a esta prática tradicional ${ }^{61}$

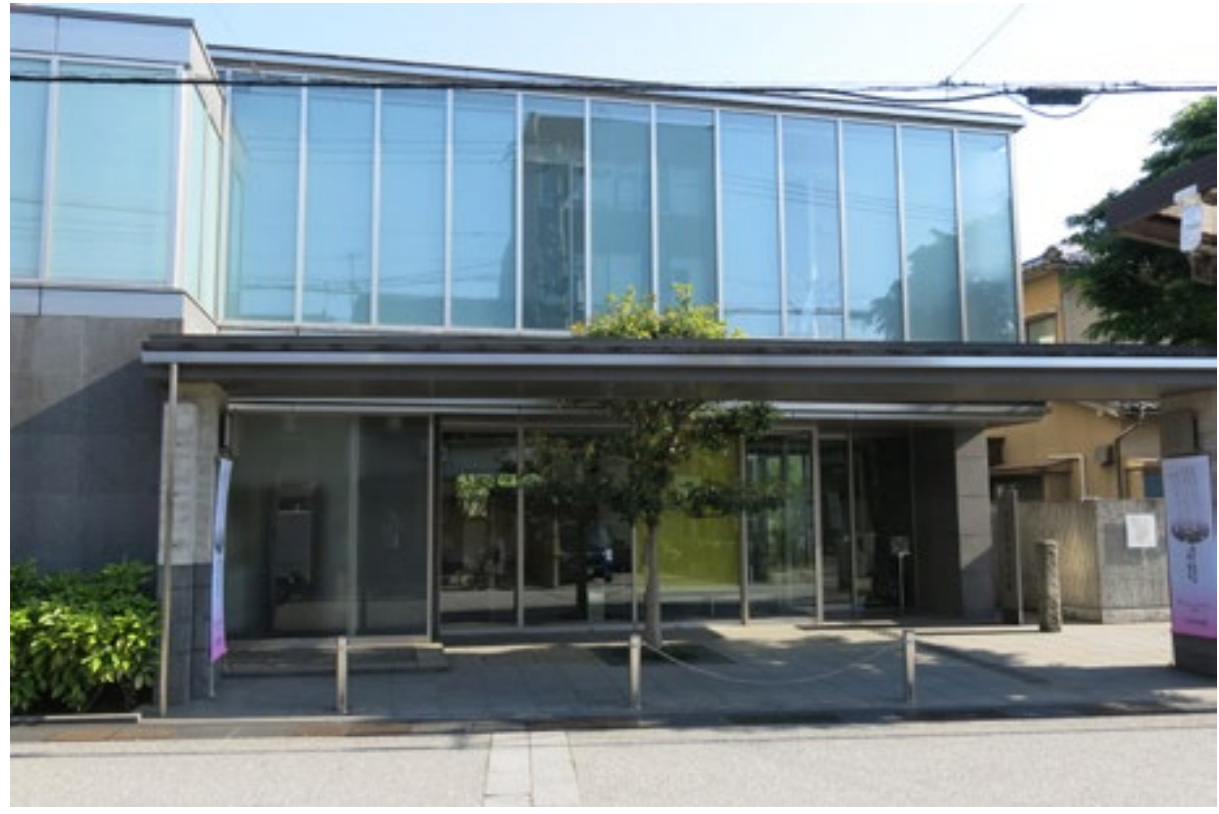

Por vezes, como no caso da casa-museu dedicada ao poeta Muro Saisei, a edificação é contemporânea, e incorpora alguns elementos simbólicos do local em que está construída, como uma lanterna de pedra ${ }^{62}$ na composição de seu jardim e espelho d'água. $\bigcirc$ poeta nunca habitou esta casa, mas, sua mãe verdadeira, que não conviveu com ele, morava neste local, descrito em sua literatura. É a partir do registro literário que o poeta faz da cidade a concepção deste pequeno museu que não reproduz ambiente doméstico algum, mas, rende homenagem ao lugar dos fatos descritos pelo poeta como lar materno. Seus objetos pessoais de várias fases da vida estão expostos em vitrines, em local discreto, no segundo pavimento da edificação, em estrutura metálica e vidro, cuja coleção preponderante é a obra literária e suas relações com outros autores japoneses documentadas por biblioteca, filmes e série de seminários organizados pelo museu.

61. A reconstrução periódica de certos edifícios religiosos é comum no Japão.

62. O torô é a lanterna japonesa de pedra que se utiliza no jardim tradicional. Objeto de decoração ou fonte de luz, está ligada a espiritualidade. Sua luz ilumina a mente, mostrando com mais clareza o caminho correto. As lanternas de pedra são parte fundamental do jardim japonês (fonte: Okano, 2012) 


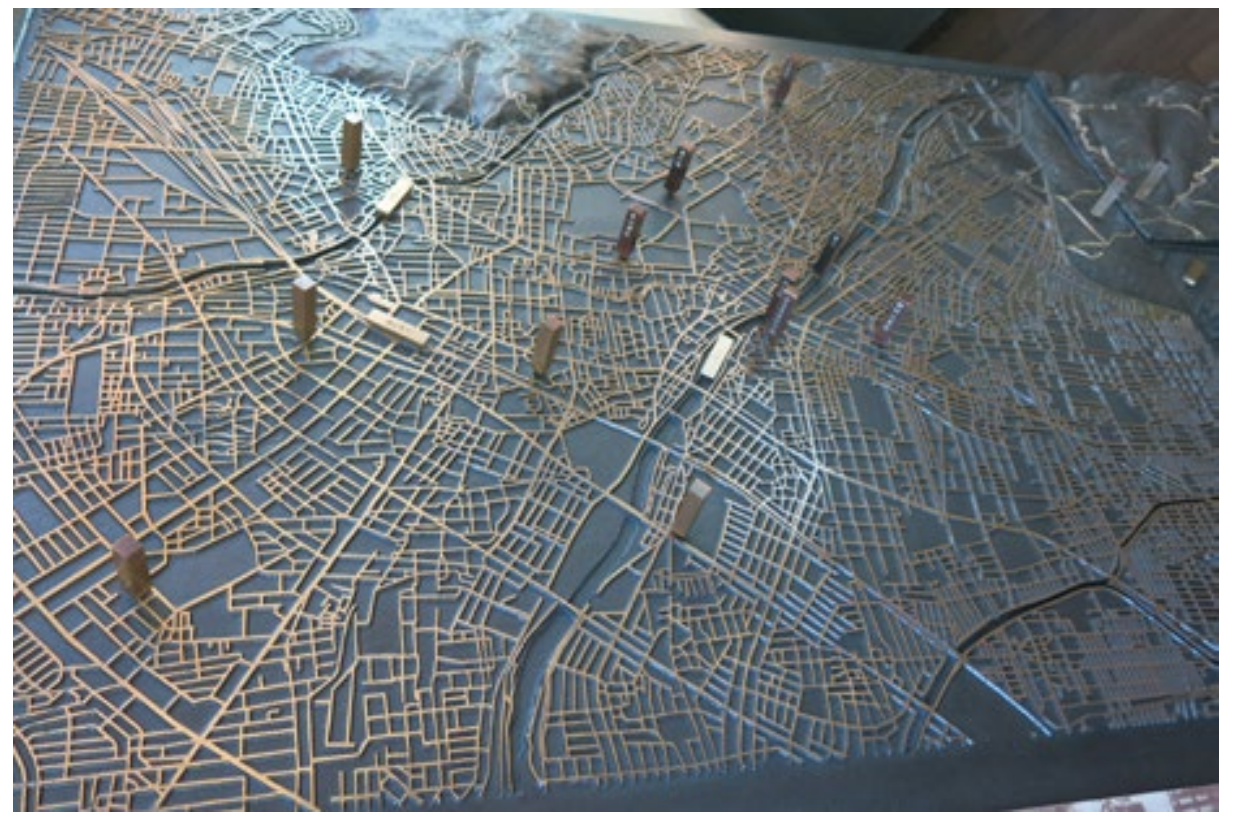

Fig. 9 - Muro Saisei Kinenkan Museum, Kanazawa, Japão. Mapa de Kanazawa. 2019. Foto A.

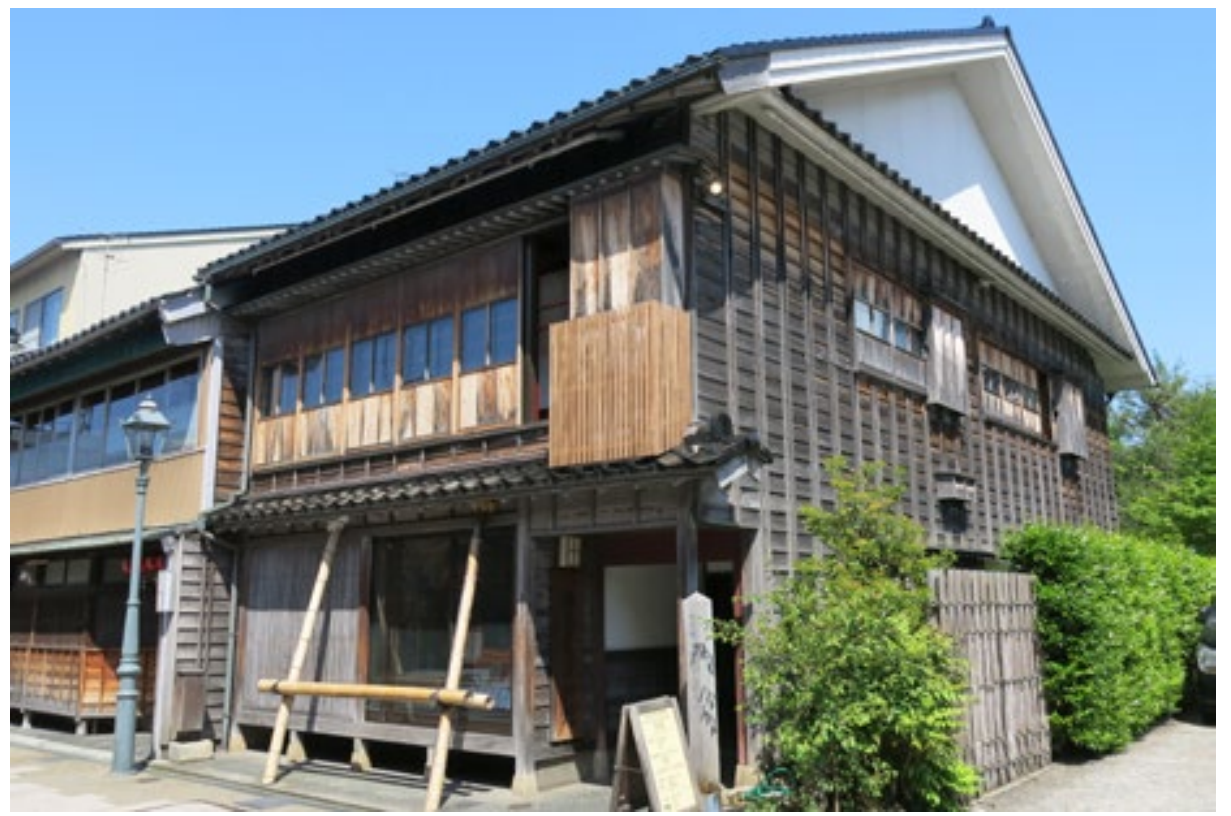

Fig. $10-$

Nishi Chaya Shiryokan Museum, Kanazawa, Japão. Fachada. 2019. Foto A.

Nishi Chaya Shiryokan Museum é uma pequena casa de madeira, no bairro tradicional de Kanazawa, em que viveu Shimada Kiyojiro, escritor do início do século XX. Sua história é contada em painéis repletos de fotos nesta tradicional construção japonesa que preserva o Ma, área de transição entre o espaço público e privado da casa e também um jardim por ele concebido, em que há a lanterna de pedra votiva. São muitas as referências à cidade neste museu, em que os mapas do município são pontuados por locais que ampliam a compreensão de sua obra literária. 
Fig. $11-$

Kawai Kanjiro Memorial Museum, Kyoto Fachada. 2019 Márcia Rossi.

Fig. $12-$

Kawai Kanjiro Memorial Museum, Kyoto. Tornos do ateliê 2019. Márcia Rossi
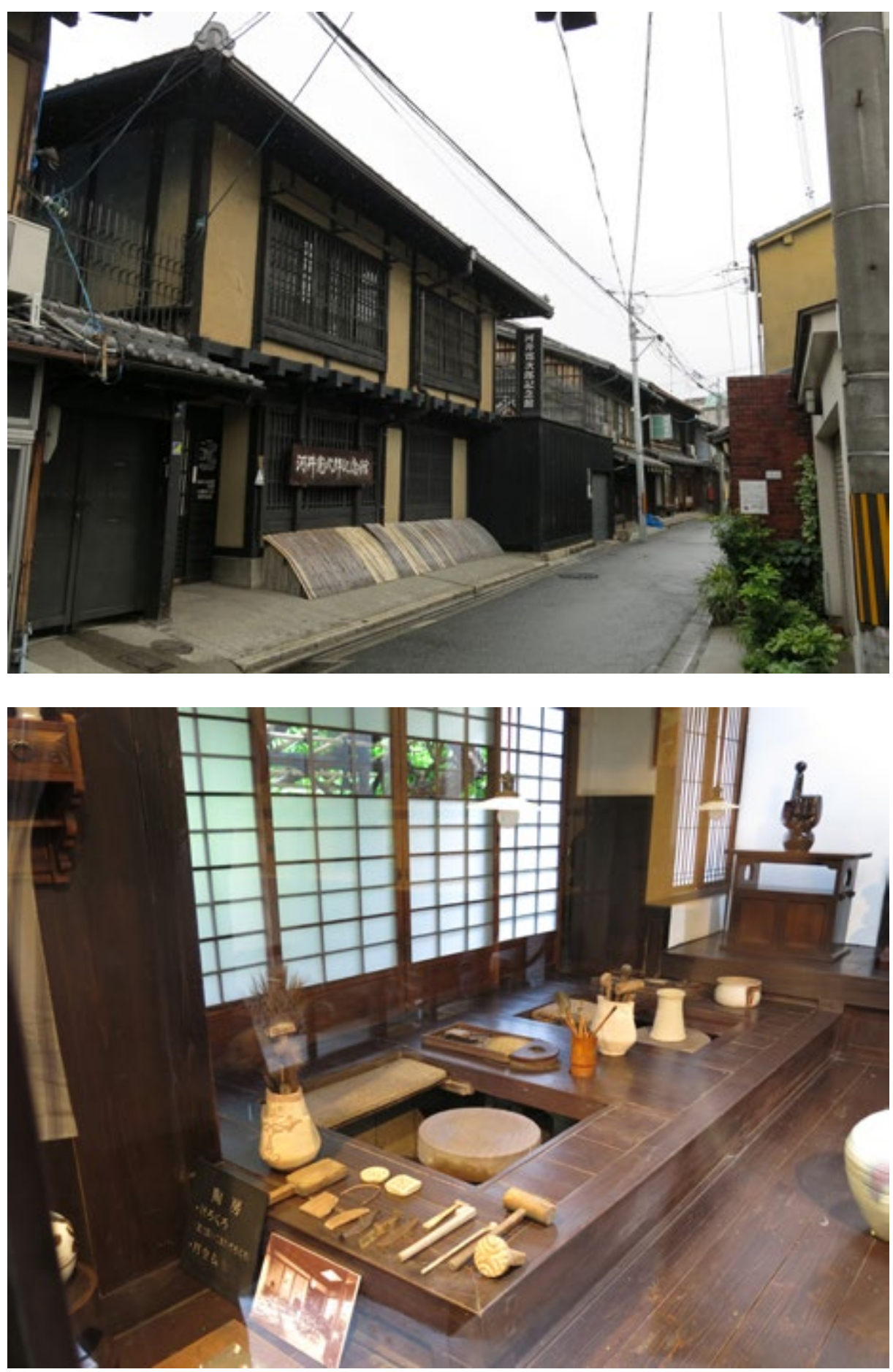

A casa de Kawai Kanjiro, ceramista que viveu em Kyoto entre 1890 e 1966, é operada por seus descendentes e preserva, utilizando seu espaço de trabalho, todos os ambientes domésticos da casa e também o grande forno Noborigama, ainda em atividade, por meio de intensa programação de cursos que disseminam o ofício do artista homenageado. ${ }^{63}$ Segundo Hartog, diferentemente do ocidente, no Japão “De

63. The National Museum of Modern Art, Kyoto apresentava à época da visita a exposição com obras de Kawai Kanjiro pertencentes à Kawakatsu Collection com 250 peças do ceramista e mais 175 de seus discípulos, em cartaz entre 26 de abril e 2 de junho de 2019. 
um tempo que não era linear, derivava uma outra figuração da permanência e uma outra relação com o vestígio." (Hartog, 2006, p. 267).

No Brasil, a referência à cidade na casa-museu não é frequente, embora a pesquisa tenha permitido identificar pela ação de algumas instituições como o Museu Casa de Guimarães Rosa, que explora marcos urbanos referenciados à vida e à obra do autor mineiro, por meio de circuitos de visitação pela cidade de Cordisburgo, MG, e também, numa das instalações da nova museografia do Museu Casa de Portinari, em que no piso de um dos quartos da residência adesivou-se um mapa da cidade de Brodósqui, SP, assinalando as conexões com a história da vida do pintor. Ambos os museus citados, entre outros, se valem de iniciativas da ação museal como instrumentos de dinamização desta relação e podem ser evidenciadas como experiências de conjunção casa-museu/cidade.
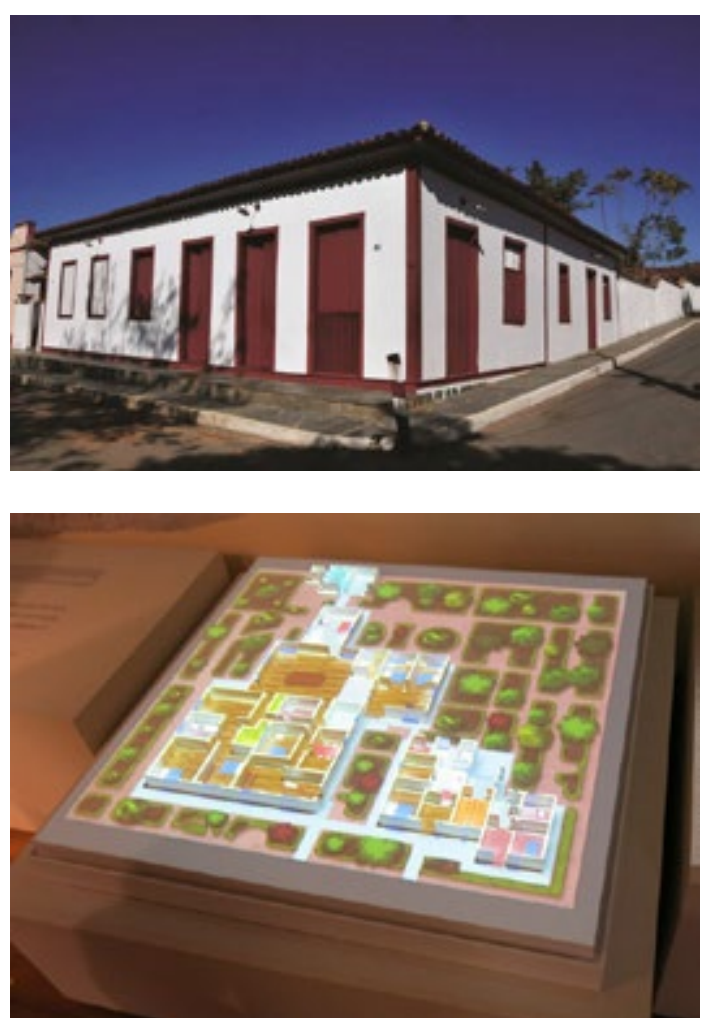

Fig. 14 - Museu Casa de Portinari, Brodósqui, SP. Maquete virtual da casa. 2018. Foto A
Fig. 13 - Museu Casa de Guimarães Rosa Cordisburgo, MG Mapa de Cordisburgo. 2017. Foto A.

Museu Casa de Porti-
A ação destas casas-museu, potencializada por seus dirigentes e pessoal técnico, tem se mostrado uma alternativa de leitura das cidades em que se inserem tendo por base a história dos seus patronos. A investigação empreendida ao longo desta pesquisa mostrou que outros vínculos entre casa-museu e cidade, entre eles o aqui sugerido a partir de sua materialidade, podem testemunhar o urbano como processo, constituindo outras camadas de observação desta tensão. 


\section{CASADO}

\section{CONSELHEIRO}

\section{RODRIGUES}

ALVES

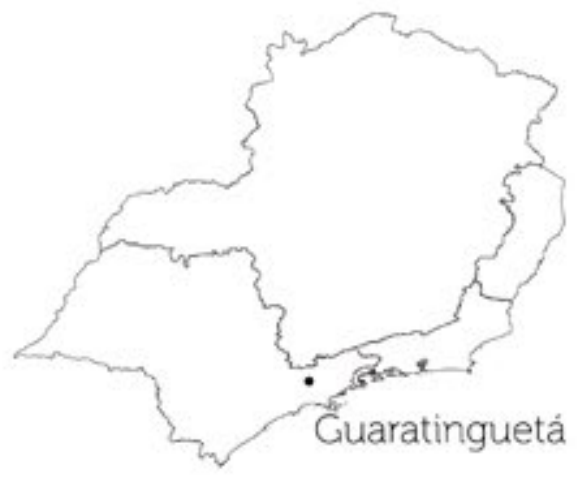
Endereço:
Rua Dr. Moraes Filho, 41 - Centro Histórico.
Cidade:
Guaratinguetá

Arquiteto:

Data de construção:

meados séc. XIX

\section{Periodo(s)}

de reforma:

2009-2017

Técnicas

construtivas

Taipa de pilão.

Dados da casa-museu

Inauguração do museu:

Área do terreno:

Pavimentos:

$\mathrm{T}+1$

Área do térreo

$315,15 m^{2}$

Área do $1{ }^{\circ}$ pav:

$315,15 \mathrm{~m}^{2}$

Área total:

$630.3 m^{2}$

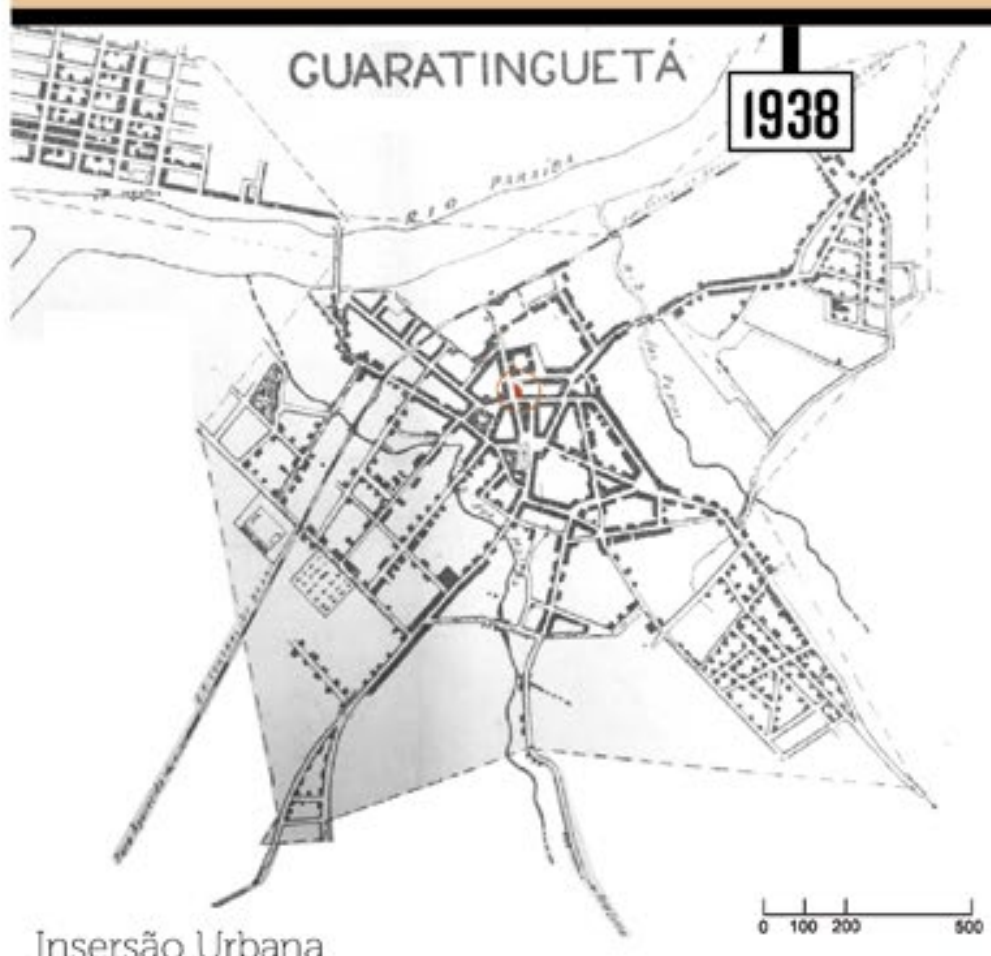



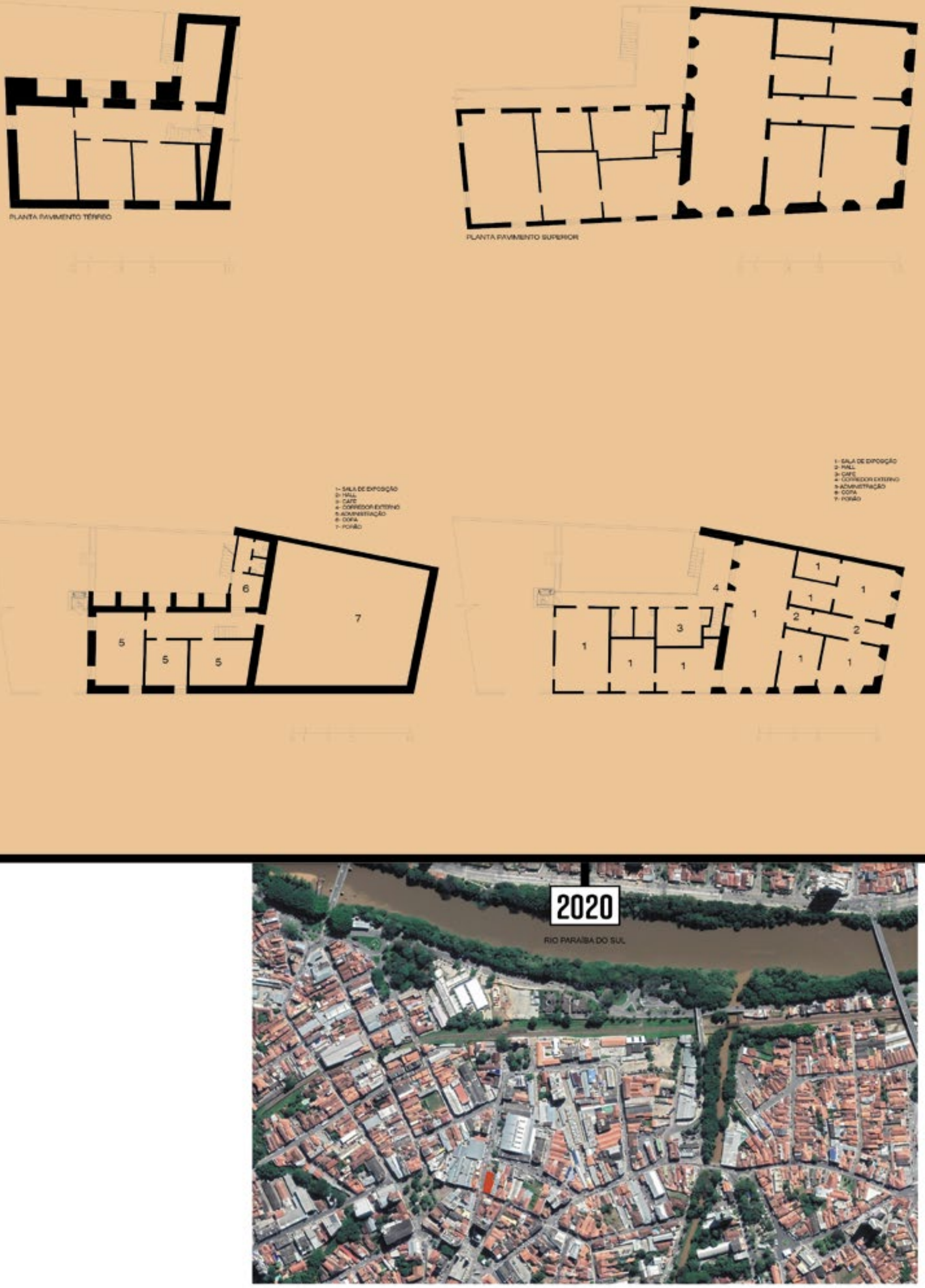



\section{ENREDOS EM DISPUTA}

Procuro aqui debater alguns vieses da relação casa/espaço urbano expressos nas casas-museu, considerando as categorias espaço e lugar, compreendendo a casa-museu como fato arquitetônico a informar tensões em diversas escalas, seja a do ambiente doméstico, da interação entre casa e lote urbano, entre o imóvel e o bairro e entre a casa e a cidade, especialmente em imóveis tombados, tendo em vista a capacidade de ressemantização do bem ${ }^{64}$ implícita na operação.

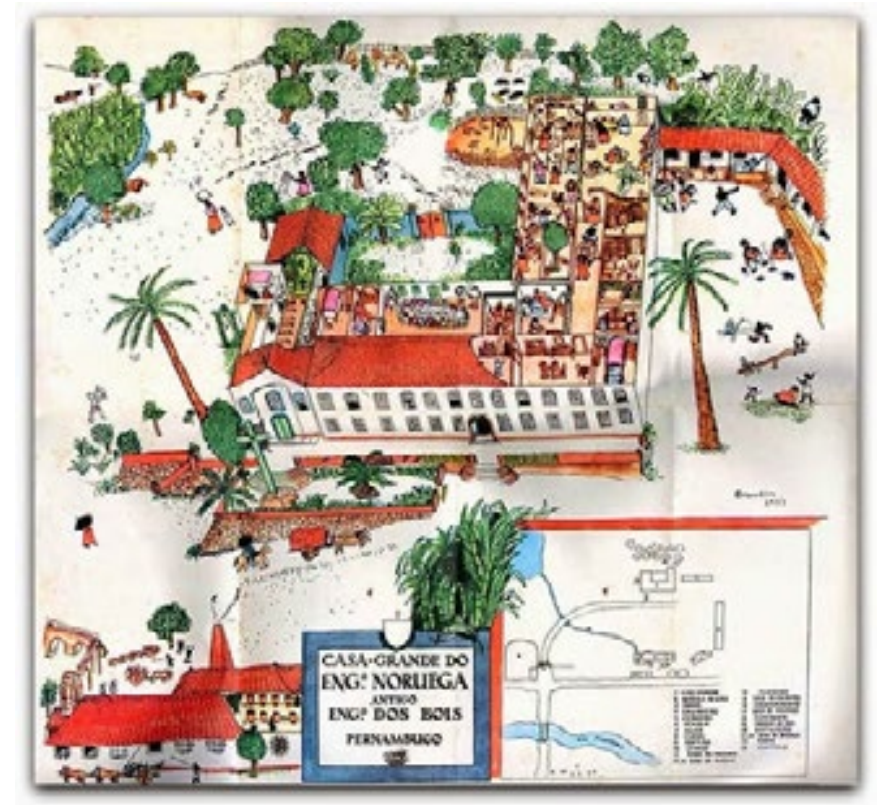

Gilberto Freyre cita o autor do Declínio do Ocidente visando atribuir à casa-grande brasileira do século XVI caráter identitário e complementando com "[...] à energia do sangue que imprime traços idênticos através da sucessão dos séculos deve-se acrescentar a força cósmica, misteriosa, que enlaça num mesmo ritmo os que convivem estreitamente unidos" (2006, p. 36). Casa-grande e senzala foi publicado três anos depois da abertura da considerada primeira casa-museu brasileira, a Casa de Rui Barbosa, na rua São Clemente, no Rio de Janeiro. Para além da importância da inflexão que se impõe nos rumos do país naqueles anos 1930 no Brasil, há nesta proximidade de datas, a da publicação do livro do autor pernambucano e a da musealização da casa do Águia de Haia, uma divergência de propósitos que ainda permanece. Embora seja senso comum a importância da arquitetura residencial para a compreensão histórica, como anuncia o texto de Gilberto Freyre, a preservação destes exemplares está quase sempre
Fig. 15 - Ilustração em aquarela e bico de pena feita por Cícero Dias para - livro Casa Grande \& Senzala. Acervo da Fundação Magdalena e Gilberto Freyre.

64. Expressão usada por Maria de Lourdes Londres Fonseca citada no texto. 
condicionada a homenagear figuras públicas, exceto raros casos cuja mitificação do arquiteto autor do projeto substitui a personagem que as habitou. A materialidade da casa, entretanto, permanece, a despeito de propósitos, intenções e planos, como documento da cidade que produz e da qual é produto.

No comentário de Freyre, o sentido do convívio comunitário referia-se aos habitantes que coexistiam em espaço não só de moradia, mas, que representou "[...] todo um sistema econômico, social, político: de produção [...]; de trabalho [...], de religião [...]" (2006, p. 36). A casa musealizada, situada na cidade, também assume características específicas a cada lugar em que se implanta. Constrói a cidade e é construída por ela.

\section{Casa-museu Magdalena e Gilberto Freyre, Recife, PE}

A Casa Museu Magdalena e Gilberto Freyre, no bairro de Apipucos, em Recife, PE, conhecida também como Vivenda Santo Antônio de Apipucos, foi transformada em Fundação em 11 de março de 1987. Casa-grande pernambucana do século XIX, adquirida pelo antropólogo em 1930, abriga a Fundação Gilberto Freyre, destinada a preservar e divulgar o acervo documental coletado e produzido por Gilberto Freyre como escritor e estudioso do homem das áreas tropicais ${ }^{65}$. Situada em meio à densa mata que pertence ao terreno da Fundação, a casa desenvolve diversos programas de ação cultural. Frequente em outras casas-museu, a inexistência de controle das condições de temperatura e umidade adequados compromete a conservação das peças, tanto na extensa biblioteca como os quadros, gravuras e objetos de arte da coleção. $\bigcirc$ extenso jardim que envolve as edificações do complexo composto por remanescente de mata atlântica atua à maneira de uma barreira aos efeitos nocivos do intenso fluxo de veículos fruto da urbanização da região, enquanto a ação museal se dá centrada na articulação com a rede de ensino local. ${ }^{66}$

\footnotetext{
65. Disponível em: <http://fundacaogilbertofreyre.blogspot.com/>. Acesso em: 15/06/2016.

66. Em visita à Fundação, em 15/08/2017, fui recebido pelo Serviço Educativo da Casa-museu que me forneceu as informações aqui descritas.
} 


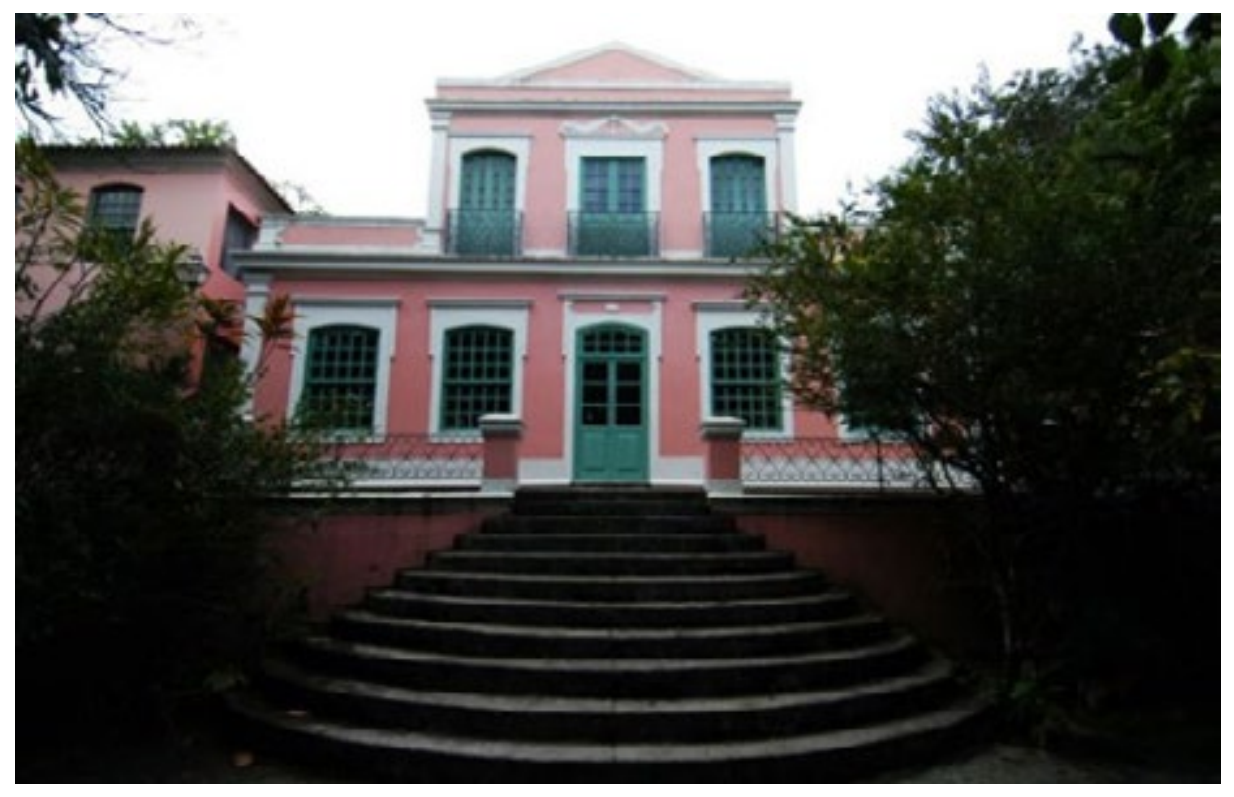

Fig. $16-$ Casa-museu Magdalena e Gilberto Freyre, Recife, PE. 2018 Foto A.

A presença do antropólogo é simulada de forma singela por meio uso de um boneco em escala natural feito em papier mâché, sentado em cadeira de balanço dentro da biblioteca com trajes de época, que o caracterizam de forma idealizada. Tal recurso encontra-se utilizado em várias casas-museu, como ponto extremo da mimese, somando a personagem à possibilidade de testemunho da vida privada, congelada naquele momento preciso com o qual o projeto museológico fantasia.

A centralidade do cotidiano e das práticas dele decorrentes justificam pensar a casa-museu e sua relação com a cidade a partir do trabatho de Michel de Certeau, cuja conceituação de espaço pode assim ser sintetizada: existe sempre que exista movimento. Para o autor, o espaço é o efeito produzido pelas operações que o orientam, o circunstanciam e o temporalizam. O lugar para De Certeau é uma configuração instantânea de posições. Para ele o espaço está para o lugar como a palavra está para o ato de fala. Em suma, o espaço é um lugar praticado.

De Certeau, que considera a ida a uma casa-museu uma visita consentida num espaço que contribuiria para revelar o segredo e a intimidade da personagem, reconhece, entretanto, que, a habitação torna visível a ambição social e o nível de renda de seus ocupantes, distinguindo neste documento, para além da disposição das peças, dos equipamentos de conforto e estado de manutenção, a sua situação na cidade. É assim que a casa de Gilberto Freyre informa, por meio de seu mobiliário austríaco de madeira vergada e palhinha, por sua implantação no terreno a articular edifícios em função de lógica de produção, por sua posição na malha da cidade, o antropólogo e a cidade mutuamente. 
A casa é produto de técnicas, neste estudo, compreendidas na acepção dada ao termo por Milton Santos, como conjunto de meios instrumentais e sociais com os quais o homem realiza sua vida, produz e ao mesmo tempo cria espaço. A cidade seria a conjunção destas diversas técnicas, de diferentes temporalidades de cada ponto próprio do espaço a estabelecer um tempo do lugar. A casa de moradia erige a ideia do espaço urbano como resultado de uma acumulação, em que edificações permanecem, outras são demolidas, novas surgem, na cidade, palco de tensões entre agentes públicos e privados.

Para Santos, o espaço "[...] seria o conjunto indissociável de sistema de objetos, naturais ou fabricados, e de sistemas de ações, deliberadas ou não" (2013, p. 46). Desta maneira a alienação do homem urbano se processaria, entre outras razões, também por uma contínua perda referencial, e, em tempos de acelerada mobilidade, geraria demanda por novas relações de pertencimento, fundadas em experiências e repertórios exógenos.

"O território é o chão e mais a população, isto é, uma identidade, o fato e o sentimento de pertencer àquilo que nos pertence" (Santos, 2001, p. 47), afirmação que esclarece alguns dos sintomas da alienação urbana, dentre os quais os referidos nas missões de instituições museais, cujos objetivos, preconizados pelo International Council of Museus (ICOM), preveem o atendimento à crescente diversidade de públicos, contribuindo com a construção de novas identidades, fundadas na experiência da cidade ${ }^{67}$.

A tensão entre casa e cidade pode ser evidenciada naquelas casas-museu em que o imóvel é tombado por órgãos oficiais de patrimônio de diversas instâncias, com a justificativa centrada na vida de seus patronos.

Esta investigação, embora não se limite a imóveis oficialmente tombados, quando os inclui, o faz por conta da sobreposição de narrativas específica à tipologia analisada e propõe a partir de outra visada estabelecer novas redes em conjunto edificadas à maneira de uma coleção.

67. Referência acadêmica na área de Educação, o projeto Cidades Educadoras, que se apoia nas teorias educacionais de José Pacheco, da Escola da Ponte, em Santo Tirso, Portugal, propõe a cidade como espaço de aprendizado. 


\section{Memória edificada}

Indivíduos e sociedades não podem preservar e desenvolver sua identidade senão pela duração e pela memória. (Choay, 2006, p. 112)

Françoise Choay afirma que os monumentos históricos funcionam como

[...] introdução a uma pedagogia geral do civismo, e que [...] cidadãos são dotados de uma memória histórica que terá o papel efetivo de uma memória viva, uma vez que mobilizará o sentimento de orgulho e superioridade nacionais. (2006, p. 117)

Entende a autora o tombamento como um processo de atribuição de valor cognitivo, quando embasado em critérios históricos. Os comitês, após a Revolução Francesa, já no início do século XIX, fizeram dos monumentos históricos propriedade, por herança, de todo o povo. "Dotavam-nos assim de um valor nacional e thes atribuíam novos usos, educativos, científicos e práticos" (Choay, 2006, p. 119). A criação, por François Guizot, em 1830, na França revolucionária, do cargo de inspetor dos monumentos históricos abre espaço para a utilização, pelo Estado, do patrimônio edificado como parte concreta do discurso da nação, pois segundo ele, "[...] os edifícios antigos já não contribuem para fundar um saber, aquele que é construido por sua disciplina, mas para ilustrar e com isso servir a um determinado sentimento, o sentimento nacional" (Choay, 2006, p. 129).

Entre 1840 a 1849, ou seja, em apenas nove anos, o Comitê dos Trabalhos Históricos, de 1830, e a Comissão dos Monumentos Históricos, estabelecida em 1837, já haviam tombado 3.000 imóveis. A primeira lei sobre os monumentos históricos na França data de 1887, completada por uma regulamentação em 1889. Em 1913, foi criado o Serviço dos Monumentos Históricos, um órgão estatal centralizado, dotado de uma poderosa infraestrutura administrativa e técnica (Choay, 2001. p. 148).

No Brasil, a regulamentação federal nesta área da proteção do patrimônio, segundo Maria Lúcia Bressan Pinheiro (2011), iniciou-se, com manifestações relativas à defesa do patrimônio histórico e artístico, no ano de 1920, com o anteprojeto de lei de autoria do Prof. Alberto Childe, conservador de antiguidades clássicas do Museu Nacional, e com a fundação, em 1922, do Museu Histórico Nacional (MHN), com o projeto de lei de Luiz Cedro de 1923, este citando abertamente o exemplo da França revolucionária. 
Seguiram as tentativas de implantação de uma política preservacionista sistematizada no âmbito do Estado com o projeto de Augusto de Lima, de 1924, o ofício de Nereu Sampaio à Diretoria do Patrimônio Nacional, de 1925 , "[...] órgão subordinado ao Ministério da Fazenda encarregado do arrolamento e manutenção dos bens de propriedade do governo federal, e nada tinha a ver com a salvaguarda do patrimônio histórico e artístico nacional" (Pinheiro, 2011, p. 143), a iniciativa de Fernando de Mello Vianna, governador de Minas Gerais, também em 1925, a criação da Inspetoria Estadual de Monumentos Nacionais na Bahia, em 1927, e da Inspetoria Estadual dos Monumentos Nacionais de Pernambuco, em 1928. Prosseguiram outras iniciativas, como a mobilização criada pelas comemorações do bicentenário do Aleijadinho, em 1930, as preocupações com a decadência e a descaracterização de Ouro Preto, MG, e o projeto do deputado José Wanderley de Araújo Pinho, de 1930, que seria a base do Decreto Lei $n$ - 25 de 30 de novembro de 1937. Além destas disposições citadas, a autora aponta ainda a instituição de Ouro Preto em Monumento Nacional, em 1933, e a implementação da Inspetoria de Monumentos Nacionais do Museu Histórico Nacional, em 1934, como as ações precursoras do então Serviço do Patrimônio Histórico e Artístico Nacional (SPHAN), instaurado em 1936 pelo Ministro da Educação Gustavo Capanema com base no anteprojeto elaborado por Mário de Andrade.

O protagonismo de Mário de Andrade na antevisão que continha seu anteprojeto evidencia-se atualmente por meio de sua presença nos trabalhos acadêmicos recentes na área do patrimônio ${ }^{68}$ e também pela constituição de casa-museu em sua homenagem à rua Lopes Chaves, no bairro da Barra Funda, em São Paulo, inserida na rede de museus literários de São Paulo69.

Desde sua oficialização pelo governo Getúlio Vargas, em 1937, o atual Instituto do Patrimônio Histórico e Artístico Nacional (IPHAN) desenvolveu instrumentos legais e práticas de preservação do patrimônio edificado, como parte do projeto de construção de uma ideia de nação brasileira. Uma análise da relação de bens tombados pelo órgão faz parecer que a estratégia (De Certeau) utilizada seria a de promover um apagamento das diferenças regionais em favor de uma unidade nacional, muito identificada com o projeto do Estado Novo, que incluía, entre outras iniciativas, a negação do período chamado de Primeira República, por meio de um esforço de modernização da pátria.

68. Entre outros trabalhos acadêmicos, a dissertação de mestrado defendida na FAUUSP por Bianca Maria Abbade Dettino, intitulada Mario de Andrade colecionador: olhar para além de seu tempo, explora a sua coleção de arte referenciada à casa onde morou.

69. A rede de museus literários será descrita mais adiante nesta pesquisa. 
O Estado brasileiro promoveu, assim, a implantação de diversos monumentos e símbolos que visavam identificar o que seriam o povo brasileiro, sua tradição, sua história. Segundo Sérgio Miceli:

\begin{abstract}
O SPHAN é um capítulo da história intelectual e institucional da geração modernista, um passo decisivo da intervenção governamental no campo da cultura e um lance acertado de um regime autoritário empenhado em construir uma "identidade nacional" iluminista no trópico dependente. (1987, p. 44)
\end{abstract}

Assim, os bens tombados, passam a compor um conjunto de elementos associável a uma coleção, na medida em que pode revelar, em sua contemplação, o invisível ou a abstração de um conceito de nação.

Se, durante muitos anos, a gestão do IPHAN tem sido, por vários autores, associada à construção de uma "unidade" nacional, aparando arestas, reconfigurando monumentos, de forma a justificar uma visão preponderante de um passado arquitetônico legítimo e que, neste processo, promoveu o esquecimento ativo ${ }^{70}$ de muitas manifestações, que poderiam compor o patrimônio cultural brasileiro, já nos anos recentes, o órgão tem se utilizado de outras ferramentas legais e de renovação das suas práticas, com o intuito de operar a construção de um discurso que parece procurar se pautar pela diversidade, alteridade e respeito às condições locais. Assim, a chancela da paisagem cultural, o patrimônio imaterial e, mesmo, o investimento do IPHAN em capacitação de mão de obra e desenvolvimento de comunidades, dentro do programa de Ação das Cidades Históricas, são práticas que, ao marcarem uma ação politicamente diversa daquela primeira, acompanham a ampliação do conceito de patrimônio expresso nas cartas patrimoniais e evidenciam também mudança no conceito de nação, no sentido de um âmbito apto à inclusão dos diversos setores que a compõem ${ }^{71}$.

Este movimento é anunciado por François Hartog para quem: "[...] hoje, o privilégio da definição da história-memória nacional tem a concorrência ou é contestado em nome de memórias parciais,

70. Ver nota 20.

71. O Governo Federal, recentemente, vem providenciando demissões de técnicos e contratações sem base adequada ao IPHAN, parte da possivel estratégia de desestabilização dos órgãos ligados ao extinto Ministério da Cultura, conforme afirma Renata Vieira da Motta: "No IPHAN, a ausência de critérios técnicos nas nomeações dos cargos comissionados, somada aos inúmeros dilemas na área de gestão de pessoas na administração pública nacional, definem uma arena altamente conflitiva e uma preocupação quanto o agravamento, no curto e médio prazo, dos riscos na gestão do patrimônio e cultura nacionais" apontando para uma situação de profunda incerteza nos rumos da preservação do patrimônio. Disponivel em: <https://www.clp.org.br/guerra-cultural-e-os-impactos-na-gestao-publica-da-cultura-mlg2/>. Acesso em: 15/02/2020. 
Fig. 17 - Casa de Rui Barbosa Rio de Janeiro, RJ. Fachada. Fonte: www. casaruibarbosa.gov.br

setoriais, particulares (de grupos, associações, empresas, coletividades, etc.) que querem se fazer reconhecer como legítimas, tão legítimas, até mesmo mais legítimas." (2006, p. 267).

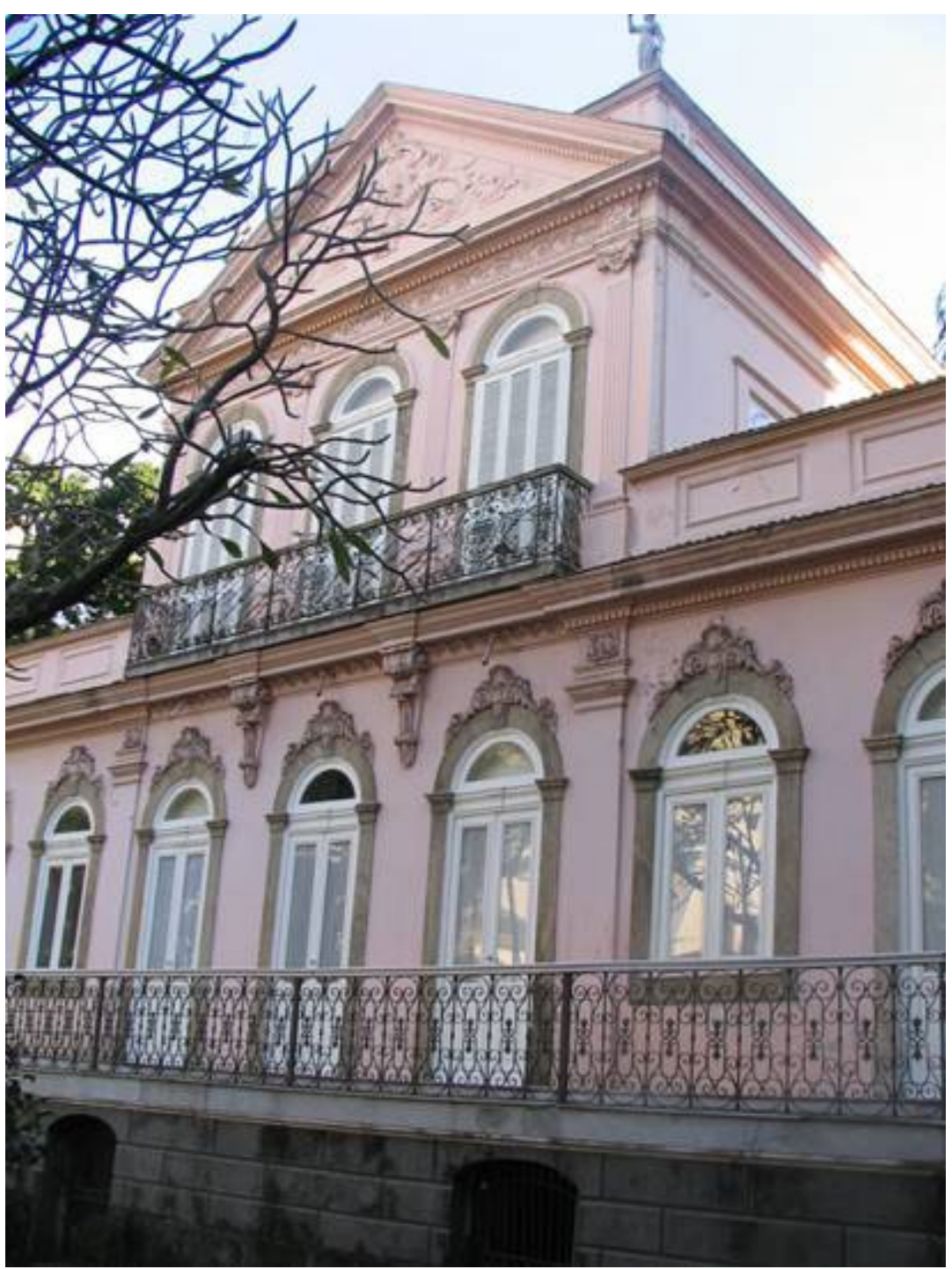

Casa de Rui Barbosa, Rio de Janeiro, RJ

Situada no bairro de Botafogo, no Rio de Janeiro, RJ, em lote de grandes dimensões que atesta a antiga ocupação do bairro com chácaras, no final do século XIX, o imóvel senhorial fundou a primeira casa-museu brasileira por decreto, em 1928, e abriu-se ao público em 1930.

A casa, circundada por extenso jardim, possui edifício de quatro andares anexos ao fundo do terreno, instalados em 1972, destinados às áreas administrativas, acervo, centro de pesquisa e auditório. Concebida originalmente em função da extensa biblioteca como expressão do gênio intelectual do patrono, a casa de Rui Barbosa foi sendo montada aos poucos, a partir da recompra dos itens de mobiliário e 
peças originais que haviam sido vendidas em leilões, e complementadas com outras de maneira a reconstituir cada cômodo à maneira do período em que ali viveu a família Rui Barbosa, de 1895 a 1923. É assim que, como afirma Cláudia Reis, "o estudo do acervo deu um enfoque mais universal aos objetos, de forma a permitir seu uso educativo, como também uma abordagem sociológica." (2010, p. 67).

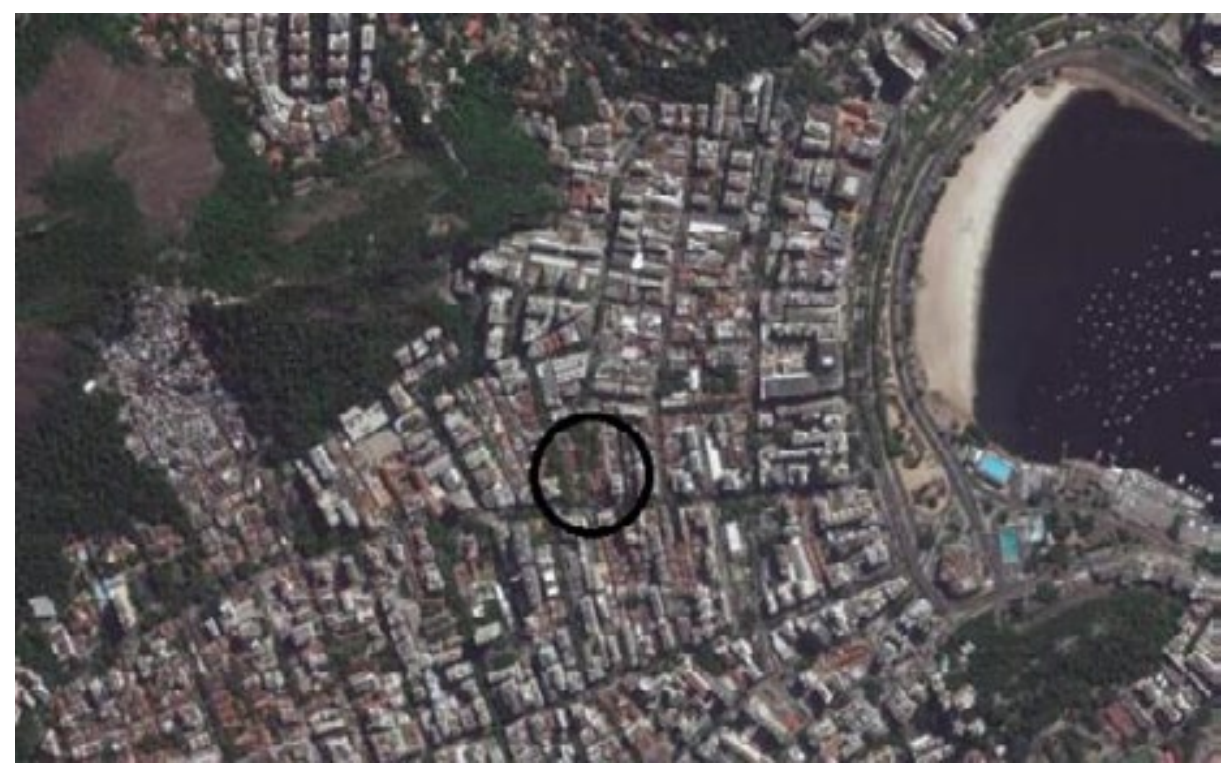

Encontra-se hoje a casa-museu num enclave entre as tensões impostas pela proximidade a comunidades de baixa renda, densidade no tráfego de veículos e pedestres, mantendo importante Centro de Pesquisas em História, Direito, Filologia e Políticas Culturais, arquivo de literatura, laboratório de conservação e de restauração de documentos e laboratório de digitalização para defesa e difusão de acervos bibliográficos e documentais, promovendo frequentes atuações de estímulo à pesquisa crítica em sua coleção, encontros científicos na área de conservação. ${ }^{72}$

\section{Casa do Conselheiro Rodrigues Alves, Guaratinguetá, SP}

A Casa do Conselheiro Rodrigues Alves, em Guaratinguetá, SP, solar em que o ex-presidente da república viveu com a família, na rua Dr. Moraes Filho, situada no centro da cidade, foi edificada em taipa de pilão, recebeu, posteriormente, encamisamento de tijolos em sua parte externa. Objeto de tombamento pelo Instituto do Patrimônio

\section{Fig. 18 - Casa de Rui Barbosa Rio de Janeiro, RJ. Imagem aérea. 2020. Desenho do autor sobre imagem Google maps.}

72. Em continuidade ao desmantelamento do sistema de cultura e museus promovido pelo novo governo federal brasileiro, a Fundação Casa de Rui Barbosa sofreu recentemente (07/01/2020), com a demissão de vários pesquisadores, consequente descontinuidade de projetos, pela substituição de sua direção por profissional não qualificado tecnicamente, estranho aos estudos ruianos. 
Fig. 19 - Casa do Conselheiro Rodrigues Alves, Guaratinguetá, SP. Fachada. Foto A.

Artístico Nacional (IPHAN), em 1969, por meio de processo repleto de controvérsias entre o governo e os técnicos do instituto, no início do período da Ditadura Militar no Brasil, a casa foi doada à Secretaria de Estado da Cultura, em 1979, teve sua museografia modificada e foi reaberta ao público, em 13 de junho de 2017, após oito anos de fechamento. Medidas previstas pela atual direção da casa preconizam mitigar os efeitos da intensa deterioração da região central do município, comum em centros urbanos de cidades médias do estado de São Paulo, por meio de restrições que excluiriam possibilidades de ampliação de seu público.

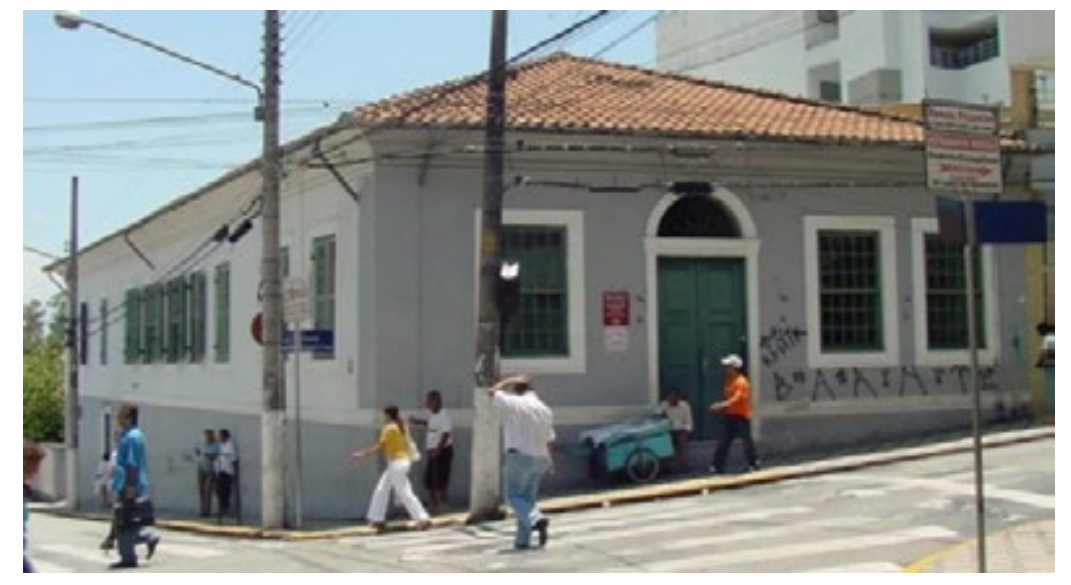

Ao analisar documentos relativos ao tombamento da casa do ConseIheiro Rodrigues Alves, enviados pelo Ministério da Cultura e trocados entre o então diretor do Instituto do Patrimônio Histórico e Artístico Nacional (IPHAN), Rodrigo Melo Franco de Andrade, e o Chefe do 4 distrito do órgão em São Paulo, Luís Saia, cuja inscrição do bem no Livro Histórico se dá em 1969, a partir de fontes documentais do arquivo do IPHAN/SP, observa-se a sobreposição de duas camadas de significação ou de atribuição de sentido à materialidade da casa. Uma primeira camada, operada pelo Governo Federal, desde o Estado Novo, período de implantação do então denominado SPHAN, em 1937, até o final da chamada "fase heroica"73, com suas tensões implícitas na participação da construção de uma ideia de nação brasileira;

73. De acordo com o portal do IPHAN, o período "em que Rodrigo Melo Franco de Andrade esteve no comando, é conhecida como a fase heroica, já que além de contribuir para o fortalecimento da instituição, também foi necessário estabelecer uma série de medidas para preservar o patrimônio histórico e cultural do Brasil. Foi nesse momento que ele recebeu a colaboração de importantes nomes brasileiros, como Oscar Niemeyer, Luiz de Castro Faria, Sérgio Buarque de Holanda, Heloísa Alberto Torres, Vinícius de Morais, Gilberto Freyre, Carlos Drummond de Andrade, Renato Soeiro e Lúcio Costa. Também se dedicaram á instituição Lígia Martins Costa, Sílvio Vasconcelos, Augusto Carlos da Silva Teles, Alcides da Rocha Miranda, José de Sousa Reis, Edson Motta, Judith Martins, Paulo Thedim Barreto, Miran de Barros Latif, Luís Saia, Airton Carvalho e Edgar Jacinto da Silva, entre outros". Disponivel em: <http://portal.iphan.gov.br/pagina/detalhes/173>. Acesso em: 8/03/2017. 
e uma segunda, operada por agentes da preservação da memória republicana e civil paulista, representada pela valorização da imagem da oligarquia cafeeira, aqui, neste episódio específico, pela iniciativa de criação dos Museus Histórico Pedagógicos no Estado de São Paulo, inicialmente capitaneado por Sólon Borges dos Reis, então diretor do Departamento de Educação da Secretaria de Estado dos Negócios da Educação, e por Vinício Stein Campos, diretor da Divisão de Museus, da Coordenadoria do Patrimônio Cultural da Secretaria de Cultura, Esportes e Turismo do Estado, a partir de 1956 até o ano de 1973.

Esta sobreposição compõe cenário para a avaliação de aspectos constitutivos das casas-museu, com suas especificidades, que contemplam, entre outras, a elevação de sua arquitetura à condição de acervo ${ }^{74}$, criando condicionantes singulares para a adequação do edifício ao público receptor e à função museal, elaborando um enredo que se utiliza do esquecimento ativo como ferramenta de construção de memórias e que pode ser analisado a partir do ponto de vista de sua recepção. Neste estudo, verifico inicialmente o processo de tombamento, por sua potência de expressar as tensões entre os diversos agentes envolvidos: IPHAN, em que os pareceres dos técnicos deixavam de ser, no final dos anos 1960, documentos determinantes para as decisões no âmbito do Conselho Consultivo, procedimento que contribuiu para a longevidade do órgão; setores conservadores comprometidos com a ideia da nação paulista e que articulavam a elevação de determinados monumentos à condição de patrimônio nacional; e a historicidade da construção de uma ideia de nação brasileira a partir da eleição, no patrimônio edificado, de um conjunto de obras que compõem uma "coleção", no sentido da sua capacidade de tornar visível aspectos intangíveis da ideia de nação.

\section{A construção da nação paulista}

O Museu Histórico Pedagógico Rodrigues Alves, na cidade de Guaratinguetá, no Vale do Paraíba, foi fundado no contexto da criação dos Museus Históricos e Pedagógicos (MHP) ${ }^{75}$ no Estado de São Paulo, iniciativa de Sólon Borges dos Reis, diretor do Departamento de Educação da Secretaria de Estado dos Negócios da Educação,

74. Ver nota 8 da Introdução, sobre a distinção entre acervo e coleção adotada nesta pesquisa

75. "Os primeiros MHP foram designados à memória dos primeiros presidentes republicanos civis e paulistas da primeira República (1890 - 1930): MHP Prudente de Morais (1894 - 1898) em Piracicaba; MHP Campos Salles (1898 - 1902) em Campinas; MHP Rodrigues Alves (1902 - 1906), em Guaratinguetá; e MHP Washington Luís (1926 - 1930), em Batatais." (Misan, 2008, p. 181) 
concretizada pelo Diretor do Departamento de Museus, Vinício Stein Campos $^{76}$, a partir do ano de 1956.

A implantação da rede de Museus Históricos e Pedagógicos no Estado de São Paulo respondeu a uma estratégia de consolidação de uma memória paulista protagonizada por várias instituições ${ }^{77}$, entre elas o Instituto Histórico e Geográfico de São Paulo (IHGSP). Exemplo é a sobreposição dos mapas de localização dos MHPs às rotas das tropas na Revolução Constitucionalista de 1932, ou às ferroviárias do estado, como ilustrado por Simona Misan, que afirma:

[...] talvez, o possivel planejamento elaborado por Stein para a implantação das diversas unidades dos MHP no estado possa ter levado em conta a importância de enlaçar os museus com a cartografia histórica do estado. Dessa forma pode-se concluir que o caráter histórico pretendido à rede de museus por Stein, além de perpetuar a memória de seus patronos, também se relaciona à história da ocupação geográfica do estado, em especial a das regiões onde os museus estão instalados [...] Tais museus, então, em certa medida, também tiveram uma outra incumbência: a de preservar as características naturais e culturais das diferentes localizações geográficas das respectivas cidades que integraram a rede de museus. (2008, p. 186)

Fig. 20 - Museus Históricos Paulistas (1956 - 1970). Fonte: (Campos, c. 1970)

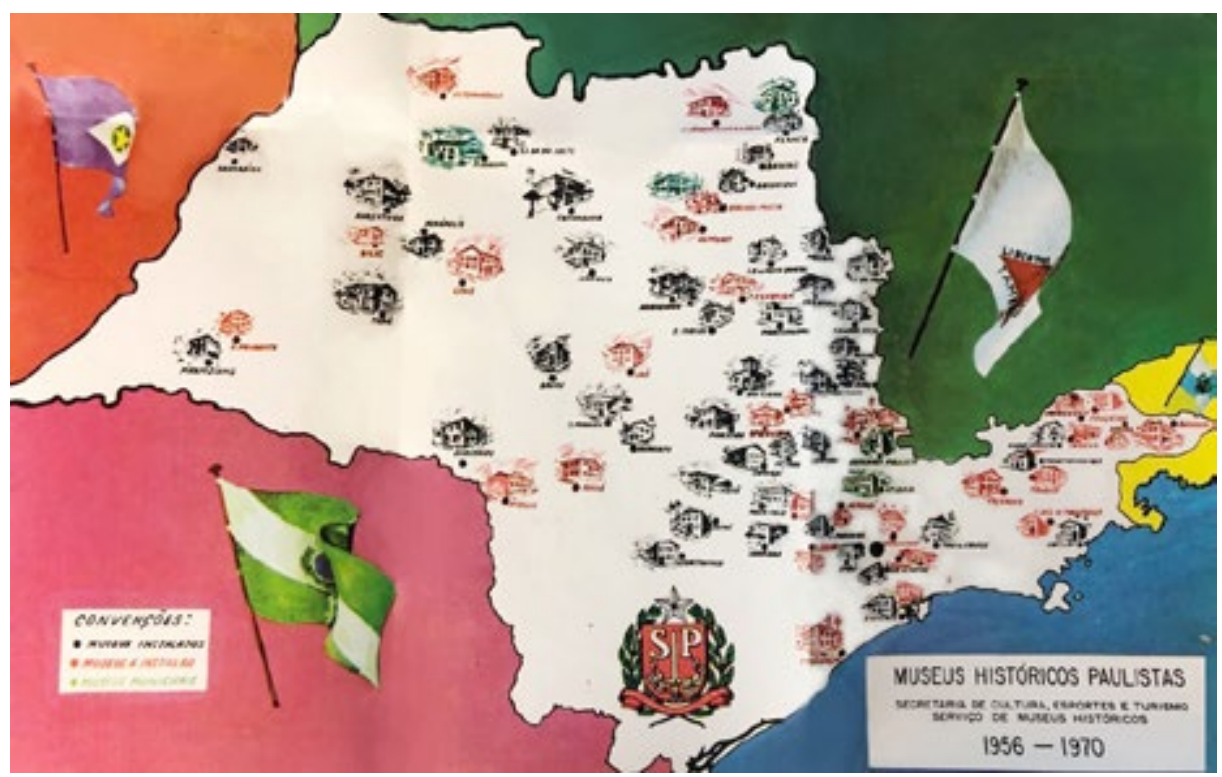

76. Vinício Stein Campos (1908 - 1990), diplomado em pedagogia em 1932, em Santa Bárbara d'Oeste, SP, onde lançou o semanário O Constitucionalista. Sócio do IHGSP (1952 - 1990). Diretor da Divisão de Museus, da Coordenadoria do Patrimônio Cultural da Secretaria de Cultura, Esportes e Turismo do Estado de São Paulo, Conselheiro do Condephaat, membro da Associação dos Cavaleiros de São Paulo, do Atheneu Paulista de História e do Centro de Ciências, Letras e Artes da Academia Campinense de Letras. Autor de Elementos de Museologia (Ca. De 1970) (Misan, 2008).

77. A saber: Academia Paulista de Letras, o Departamento de Cultura da Prefeitura da capital, dirigido por Mário de Andrade, e a própria Universidade de São Paulo. 
Para escolha dos prédios que seriam sedes dos MHPs, Stein priorizava edifícios com valor histórico e quando possível, que tivessem relação direta com seus patronos, ou mesmo abrigado grupos escolares com o nome destes. Após a abertura dos museus, agia com forte presença para que estes prédios fossem tombados pelos órgãos preservacionistas. (Grigoleto, 2009, p. 49)

Segundo Simona Misan, Vinício Stein Campos:

[...] procurava priorizar a instalação dos MHPs em construções onde nasceram ou viveram os patronos dos museus. Para tanto, muitas vezes recorria ao Conselho de Defesa do Patrimônio Histórico, Artístico e Arqueológico e Turístico do Estado de São Paulo (Condephaat) de que foi membro conselheiro (1967 1975) na tentativa, em grande parte bem sucedida, de obter o tombamento do edifício para em seguida instalar o museu. (2008, p. 193)

O Museu Histórico e Pedagógico Conselheiro Rodrigues Alves de Guaratinguetá, apesar de ter sido criado por decreto em 1956, teve sua primeira instalação prevista no Instituto de Educação em 1958, porém não funcionou naquele local. Em 1965 foi instalado à Rua Visconde de Guaratinguetá, sendo posteriormente transladado para a Biblioteca Municipal, em 1969, onde encerrou suas atividades por falta de recursos. Em 1979, por iniciativa da Secretaria de Estado da Cultura, foi reaberto no prédio do Museu Municipal, no bairro do Pedregulho, com documentação reunida junto aos familiares. Finalmente em 1982, foi transferido para o atual imóvel, casa onde viveu Rodrigues Alves. $\bigcirc$ Prédio foi construído em taipa de pilão, pelo Dr. José Martiniano de Oliveira Borges, filho do Visconde de Guaratinguetá, e passou a ser moradia do Conselheiro Rodrigues Alves quando de seu casamento, em 1891. Em 1932, o prédio sediou a base da Cruz Vermelha e também de tropas federais. ${ }^{78}$

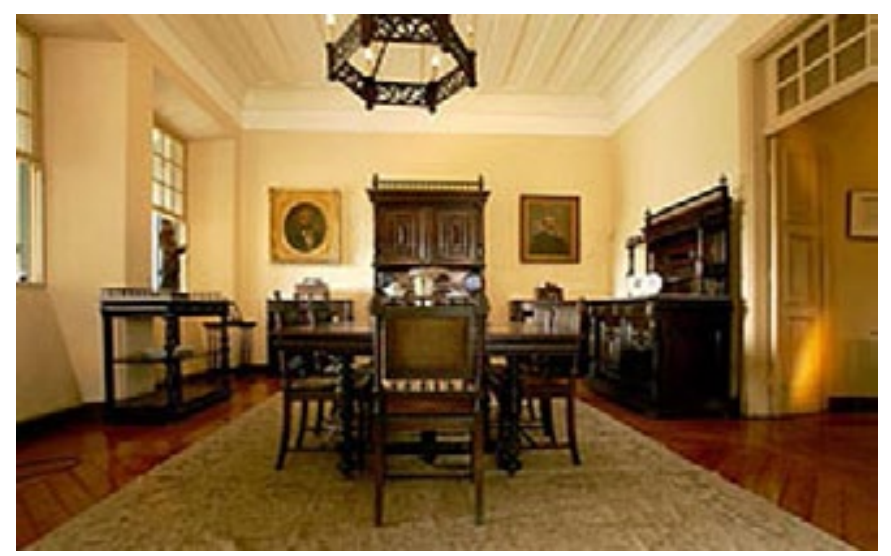

Fig. $21-$

Casa do Conselheiro Rodrigues Alves, Guaratinguetá, SP. Sala de estar da antiga museografia. Arquivo Casa do Conselheiro Rodrigues Alves.

78. Ver: Memorial Descritivo do projeto de reforma do Estúdio Sarazá, (IPHAN, 2003) (arquivo IPHAN). 
Tantas mudanças revelam que há, na cidade, intensa disputa pela "memória oficial" relativa ao Conselheiro Rodrigues Alves em que são agentes o poder público municipal e membros da elite local. Recente reforma possibilitou a reabertura do museu, municipalizado. Entretanto, em visita ao arquivo "Memória de Guaratinguetá"79 pudemos observar que a última intervenção feita na casa-museu, a destituiu dos móveis e lustres e outros elementos que ainda identificavam o espaço com a moradia do Conselheiro, deslocando também todos os arquivos que lá se encontravam para a Secretaria de Cultura do Município, onde funciona o Museu Frei Galvão.

\section{O enredo}

O patrono, no caso do MHP de Guaratinguetá, é o Conselheiro Rodrigues Alves, ex-presidente da República, representante da oligarquia cafeeira paulista, cuja biografia foi escrita por Afonso Arinos de Melo Franco, em 197380, conselheiro do IPHAN, presente à sessão que votou pelo tombamento do imóvel, em 1969.

Advogado pela Faculdade de Direito do Largo São Francisco, em São Paulo, depois da formação no Colégio Pedro II, no Rio de Janeiro, Francisco de Paula Rodrigues Alves foi promotor público, juiz de direito, deputado provincial, deputado geral, em 1885, presidente de São Paulo, deputado constituinte, deputado federal por São Paulo, ministro da Fazenda de Floriano Peixoto, senador por São Paulo, ministro da Fazenda de Prudente de Morais e presidente da República, entre 1902 e 1906.

Durante seu período presidencial, Rodrigues Alves centrou suas atenções no programa de remodelação urbana e de saneamento da capital da República. O engenheiro Pereira Passos foi nomeado prefeito da cidade do Rio de Janeiro, com plenos poderes para implantação das reformas de modernização. O porto foi ampliado, os antigos quarteirões com seus cortiços foram demolidos e os moradores deslocados para a periferia, abrindo espaço para o alargamento de ruas e a construção de novas avenidas, entre elas a avenida Central, atual avenida Rio Branco. O cientista e médico Oswaldo Cruz, que até então dirigia o Instituto de Manguinhos, foi nomeado diretor geral de Saúde Pública, implementado o combate às epidemias, como a peste bubônica e

79. A visita foi feita em 06/02/2020, com acompanhamento de Alice Bitencourt, bisneta do Visconde de Guaratinguetá.

80. Rodrigues Alves: apogeu e declínio do presidencialismo. Rio de Janeiro: J. Olympio; São Paulo: Ed. da Universidade de São Paulo, 1973. 
a febre amarela. Em 1904, a obrigatoriedade da vacinação contra a varíola levou a população carioca ao protesto nas ruas, no dia 10 de fevereiro, movimento que ficou conhecido como a Revolta da Vacina.

Rodrigues Alves enfrentou a primeira greve na capital da República, em 15 de agosto de 1903, iniciada pelos operários da indústria têxtil que reivindicavam aumento de salários e jornada diária de oito horas para todas as categorias de trabalhadores. No seu governo foi celebrado o Tratado de Petrópolis, cujas negociações foram dirigidas pelo Barão do Rio Branco, definindo os limites entre o Brasil e a Bolívia, cabendo ao Brasil a posse do Acre. A Bolívia recebeu uma compensação no valor de dois milhões de libras esterlinas, além da construção da estrada de ferro Madeira-Mamoré. No último ano de governo, apesar da oposição de Rodrigues Alves, foi concluído o Convênio de Taubaté, com apoio do Congresso Nacional. Assinado pelos estados de São Paulo, Minas Gerais e Rio de Janeiro, o convênio instituiu a estabilização cambial e a proteção aos cafeicultores, cabendo ao governo central comprar as safras com recursos financeiros externos e estocá-las para vendê-las no momento oportuno (Franco, 2001).

\title{
O tombamento do imóvel pelo IPHAN
}

\author{
Como afirma Maria Cecília Londres Fonseca
}

[...] além de instrumento jurídico com implicações econômicas e sociais, o tombamento tem sido considerado e utilizado, tanto por agentes oficiais como por grupos sociais, como o rito, por excelência, de consagração do valor cultural de um bem. (2005, p. 180)

Sobre as tensões implícitas na condução dos processos de tombamento, Maria Cecília Londres Fonseca ressalta que:

\footnotetext{
[...] em função, portanto, da natureza conflitante dos interesses em jogo no caso de proteção aos bens imóveis, e do peso dos monumentos no patrimônio histórico e artístico nacional, os processos de tombamento constituem espaços de expressão desses confrontos, onde se podem captar as várias vozes envolvidas na questão da preservação e sua influência na condução dos processos. (2005, p. 181)
}

A autora avalia o processo de tombamento como a ressemantização de um bem, de maneira análoga a Antonio Augusto Arantes, ao comentar os efeitos do processo de tombamento sobre os imóveis que aponta: 


\begin{abstract}
Através de acréscimos de significado e transformações simbólicas, esses bens são como que recriados pela "preservação" passando a carregar consigo inclusive as marcas do processo que os transformou em "bens do patrimônio" (separação do cotidiano, maior visibilidade, uma certa aura de importância e sacralidade). (1987, p. 52)
\end{abstract}

Data de 10 de junho de 1964, oito anos após o decreto que estabeleceu o Museu Histórico Pedagógico Conselheiro Rodrigues Alves, e apenas 70 dias depois da deflagração do golpe que daria início aos mais de 20 anos de Ditadura Militar, o ofício do Ministério da Educação e Cultura, assinado pelo Coronel Luiz Tenório de Brito, ao então diretor do IPHAN, Rodrigo Melo Franco de Andrade, pleiteando urgência no tombamento do prédio que abriga o Museu Histórico e Pedagógico Rodrigues Alves, solicitado pelo IHGSP a partir de proposta de Vinício Stein Campos ${ }^{81}$

Os ofícios que constam no processo de tombamento deixam claro que apesar da insistência do diretor do IPHAN, Rodrigo Melo Franco de Andrade, o processo caminhou durante os dois anos iniciais de forma morosa, culminando num parecer contrário aos tombamentos, alegado pelo diretor da 4a região do IPHAN, Luís Saia ${ }^{82}$, como resposta a um "[...] ultimato pedido de celeridade de tom incisivo" de parte de Rodrigo M.F. de Andrade, pelo parecer relativo aos tombamentos da casa de Rodrigues Alves, em Guaratinguetá, e da casa de Prudente de Morais, em Piracicaba. Pelo que escreve Franco de Andrade, na carta 375 de 5 de outubro de 1966, a decisão não caberia a ele ou à "Diretoria da DPHAN e sim ao Conselho Consultivo".

○arecer enviado por Luis Saia contém uma convincente argumentação desfavorável ao tombamento federal. Ressalta a insignificância do imóvel do ponto de vista arquitetônico e reitera suas convicções na necessidade da implantação de um órgão de preservação estadual, que a seu ver seria o âmbito mais adequado para o tombamento.

81. Este é o documento inicial arquivado no processo nํ 0738-T-64, que somente se concluiria em 2/12/1969, com a inscrição do bem no Livro Histórico sob o nํ de inscrição 419, vol. 1 , folha 68 .

82. Luis Saia (1911-1975), graduado em engenharia e arquitetura pela Escola Politécnica da Universidade de São Paulo, participou em 1936 do curso de Etnografia e Folclore do Departamento de Cultura da prefeitura paulistana, ministrado por Dina Dreyfus, quando passa a ser colaborador do Departamento de Cultura e do então Serviço do Patrimônio Histórico e Artístico Nacional, onde substitui Mario de Andrade na Chefia do 4음 Distrito, cargo que exerceu por 40 anos. Disponível em: <http://www.museudacidade.sp.gov.br/ bandeirante-luissaia.php>. Acesso em: 12/09/2016. 
O ofício n 1738 de 1 de novembro de 1966, em que o diretor do IPHAN responde ao parecer desfavorável de Luís Saia, solicitando que remeta documentação complementar para a apreciação do Conselho Consultivo, tem um teor de recusa ao enviado e prevê a aprovação do processo de tombamento pelo Conselho Consultivo do IPHAN, diferentemente do que afirma Maria de Lourdes Londres Fonseca, que seria o usual da parte do Conselho, durante a chamada "fase heroica" do órgão em que "o Conselho Consultivo, enquanto representação da sociedade junto ao SPHAN, teoricamente vinha legitimar a orientação imprimida pelos técnicos do órgão à proteção do patrimônio nacional" (2005, p. 118), este episódio demonstra o enfraquecimento da posição do técnico em função da injunção política a que se expunha o Conselho Consultivo do IPHAN naquele momento da história brasileira.

A notificação ${ }^{83}$ ao representante dos proprietários do imóvel, Francisco de Paula Rodrigues Alves Neto foi assinada por Renato Soeiro, que assumiu a diretoria do IPHAN após a morte de Rodrigo Melo Franco de Andrade.

\section{O IPHAN e as casas históricas}

A solicitação de tombamento de que trata o documento do Ministério da Cultura, assinada pelo Coronel Luiz Tenório de Brito, em 1964, contempla a casa natal do Conselheiro Rodrigues Alves e a do também ex-presidente Prudente José de Morais Barros. Diferentemente do primeiro, a conclusão do processo relativo à casa de Prudente de Morais, em Piracicaba, se deu muitos anos mais tarde (2004), como descrito na dissertação de mestrado de Maria Cristina Grigoleto, na qual avalia que a partir deste processo, os critérios para tombamento de casas natais no IPHAN tiveram que ser revistos para se adequarem às novas práticas do órgão:

\footnotetext{
Devido aos novos enfoques que foram dados no processo de tombamento, começou a ser levado em consideração a possibilidade de tombar, além do imóvel, o acervo do Museu Prudente de Morais. Na 11a reunião do Conselho Consultivo do IPHAN, em 28 de abril de 1997, ficou definido que para o tombamento de casas natais (imóveis que foram habitados por personagens ilustres e que por este motivo, tornaram-se
}

83. De acordo com o ofício no 1028-C de 8 de outubro de 1969 do processo nํ 0849/69 Tomb. Res. de 23/04/1970, publicado no D.O. em 24/04/1970. 
foco das ações preservacionistas) seria necessário que estas possuíssem elementos que permitissem a contextualização do personagem homenageado. (Grigoleto, 2009, p. 123)

Avaliando-se as datas firmadas nos processos de tombamento, segundo dados do arquivo do IPHAN-SP, observa-se que 50\% dos imóveis tombados, caracterizados como casas históricas (natais ou não), aconteceram entre 1938 e 1952. De acordo com os dados gerais de tombamento do órgão federal, este é o padrão, ou seja, a maioria dos tombamentos se deu naquele período específico, reforçando a tese de que o tombamento teria sido eficiente instrumento jurídico da Ditadura Vargas na construção de uma materialidade a justificar a nação.

Maria Cecília Londres Fonseca aponta o que para ela significa "uma concepção extremamente avançada para o seu tempo" implícita no anteprojeto de Mário de Andrade para o SPHAN:

[...] Interessa preservar como obras de arte histórica aquelas que, independentemente de seu valor artístico, constituem documentos para a história política ("criadas para um determinado fim que se tornou histórico"; "se passaram nela fatos significativos da nossa história"; "viveram nelas figuras ilustres da nacionalidade"..."que devem ser conservadas tais como estão ou recompostas na sua imagem histórica". (Fonseca, 2005, p. 100)

No livro IPHAN Patrimônio: 70 anos em São Paulo, de 2008, o arquiteto Carlos Lemos, em seu texto intitulado "Introdução aos monumentos arquitetônicos paulistas", procura explanar as possíveis dificuldades do IPHAN em compatibilizar o discurso da nação autenticamente brasileira com a São Paulo dos imigrantes e descreve a inscrição da casa de Rodrigues Alves no Livro Histórico:

Nas cidades, também encontramos a modéstia arquitetônica sempre atrelada às limitações da taipa de pilão e às modinaturas vagamente neoclássicas [...] Essa moradia, da segunda metade do séc. XIX, segundo nos relatou o historiador Carlos Eugênio Marcondes de Moura, foi construída pelo Visconde de Guaratinguetá [...] No acervo das construções oitocentistas residenciais da cidade é um exemplar que não se sobressai em nada. Paredes mestras de taipa de pilão e divisórias de taipa de mão; janelas de vergas retas à moda antiga e porta de entrada de verga de arco de pleno cinto, própria do estilo neoclássico chegado ao Rio imperial e que caracterizou todas as construções do café, inclusive as campineiras ou ituanas. Sua planta é típica da época, com duas salas da frente de intermediação entre o público e o privado, a da direita com duas alcovas destinadas a eventuais 
hóspedes. Por tudo que foi dito, o tombamento desta residência deu-se por motivos históricos porque foi a morada de um grande brasileiro, o conselheiro Rodrigues Alves. (2008, p. 119)

A casa de Rodrigues Alves em Guaratinguetá foi posteriormente tombada também pelo Condephaat (Conselho de Defesa do Patrimônio Histórico, Arqueológico, Artístico e Turístico do Estado de São Paulo) $)^{84}$.

O instrumento do tombamento quando aplicado em imóvel ocupado por casa-museu insere outras variáveis na construção da narrativa, parte do processo museal, que se encontram expressas em sua operação cotidiana. $\bigcirc$ conhecimento destes pode contribuir para uma ação mais estruturada destas instituições e ademais constituem material exponencial para estudantes em várias modalidades, em especial de arquitetura. ${ }^{85}$

A localização central da casa-museu dedicada a Rodrigues Alves assiste hoje à deterioração dos parâmetros de qualidade urbana comuns às cidades do interior de São Paulo, do vale do Paraíba, com a precarização dos espaços públicos e poluição visual e sonora propiciados por intensa atividade comercial.

84. De acordo com o processo no 0849/69 Tomb. Res. de 23/04/1970, publicado no D.O. em 24/04/1970

85.Em minha atividade docente, pude dialogar com os alunos experimentando a visita a algumas destas casas musealizadas na cidade de São Paulo, de modo, a surgir desta prática profissional, a constatação de que, embora os sistemas de representação em Arquitetura estejam se modificando rapidamente no sentido da simulação cada vez mais próxima do real, não há substituto à experiência física da Arquitetura, fundamental no aprendizado de Projeto e na compreensão da cidade como fenômeno. Os cursos de graduação em Arquitetura e Urbanismo frequentemente oferecem viagens de estudo e visitação a obras exemplares, de acordo com a seleção de certas historiografias, entretanto, a possibilidade de propiciar ao aluno a experiência de conhecer residências comuns, muitas vezes feitas por não arquitetos, e, eventualmente, soluções vernaculares, oferecendo a Casa à percepção por meio de todos os sentidos e em todas as suas dimensões, capaz de atestar a cidade que a produziu e que ajudou a produzir, foi o que motivou esta pesquisa. 


\section{CASA}

\section{GUILHERME}

DE ALMEIDA

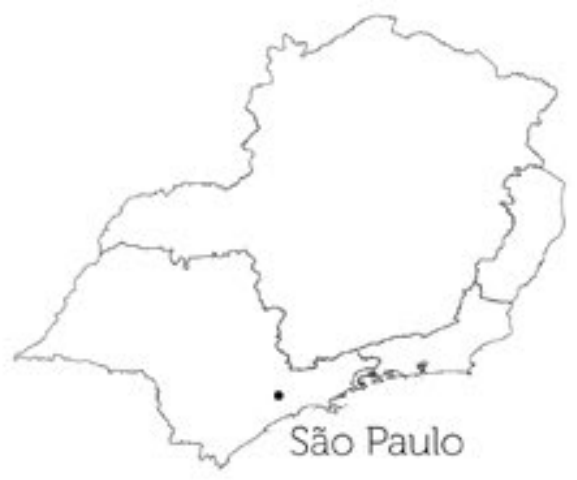

$\begin{array}{ll}\text { Endereço: } & \text { R. Macapá, 187 - Perdizes } \\ \text { Cidade: } & \text { São Paulo } \\ \text { Arquiteto: } & \text { Silvio Jaguaribe Eckman } \\ \begin{array}{l}\text { Data de } \\ \text { construção: }\end{array} & 1946 \\ \begin{array}{l}\text { Periodo(s) } \\ \text { de reforma: }\end{array} & 2011 \\ \begin{array}{l}\text { Técnicas } \\ \text { construtivas }\end{array} & \begin{array}{l}\text { Estrutura de concreto e } \\ \text { alvenaria de tijolos. }\end{array}\end{array}$

Dados da casa-museu

Inauguração

1979

Área do terreno: $\quad 377,81 \mathrm{~m}^{2}$

Pavimentos: $\quad T+2$

Área do térreo $\quad 111,98 \mathrm{~m}^{2}$

Área do $1^{\circ}$ pav: $\quad 89,42 \mathrm{~m}^{2}$

Área do $2 \%$ pav: $\quad 31,47 \mathrm{~m}^{2}$

Área total:

232,87

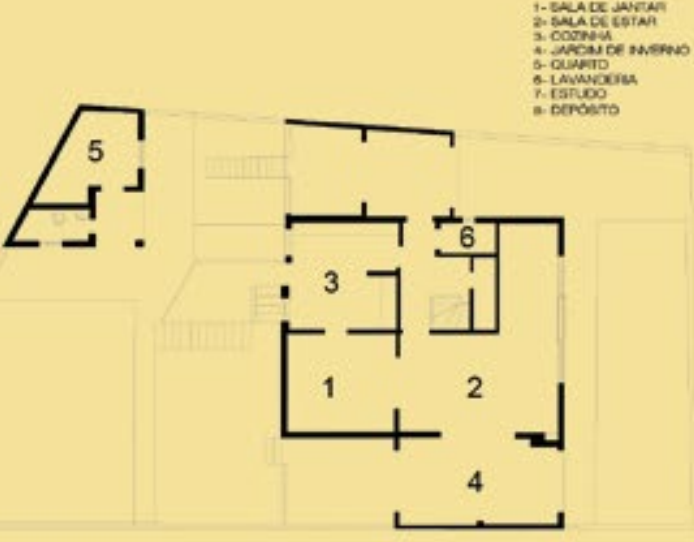

TEหreo oneceves
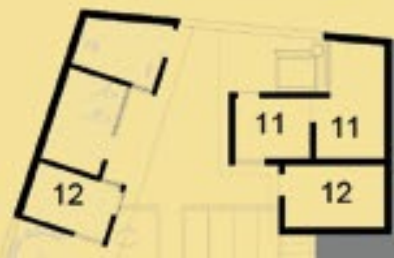

SUbSOL POS Ruroeve

0135

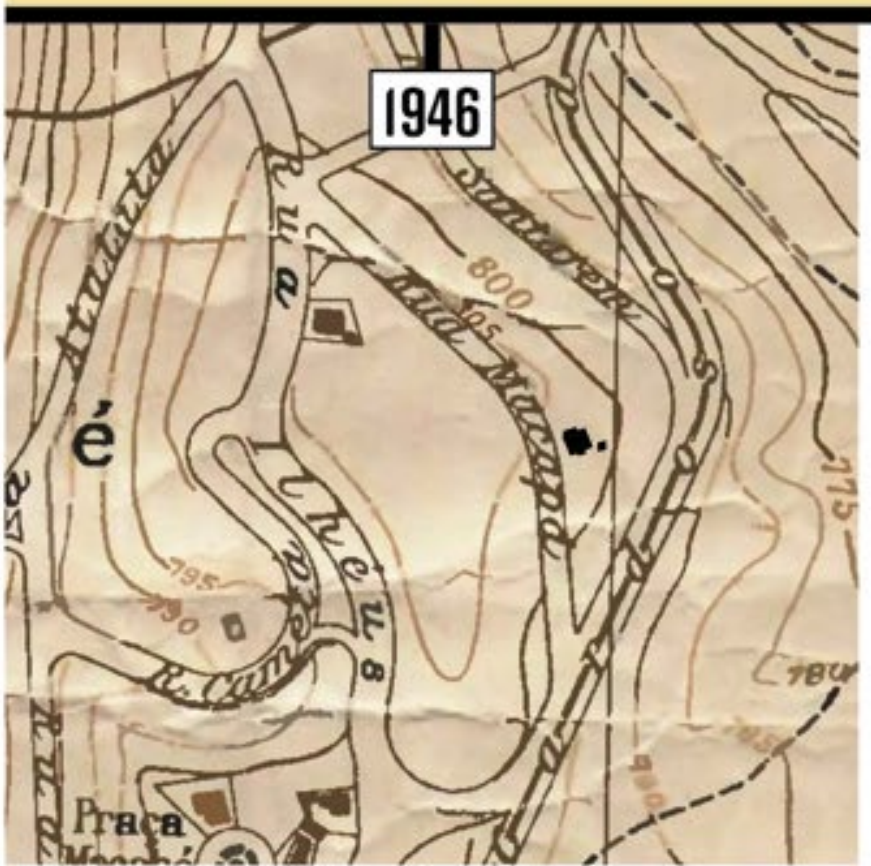



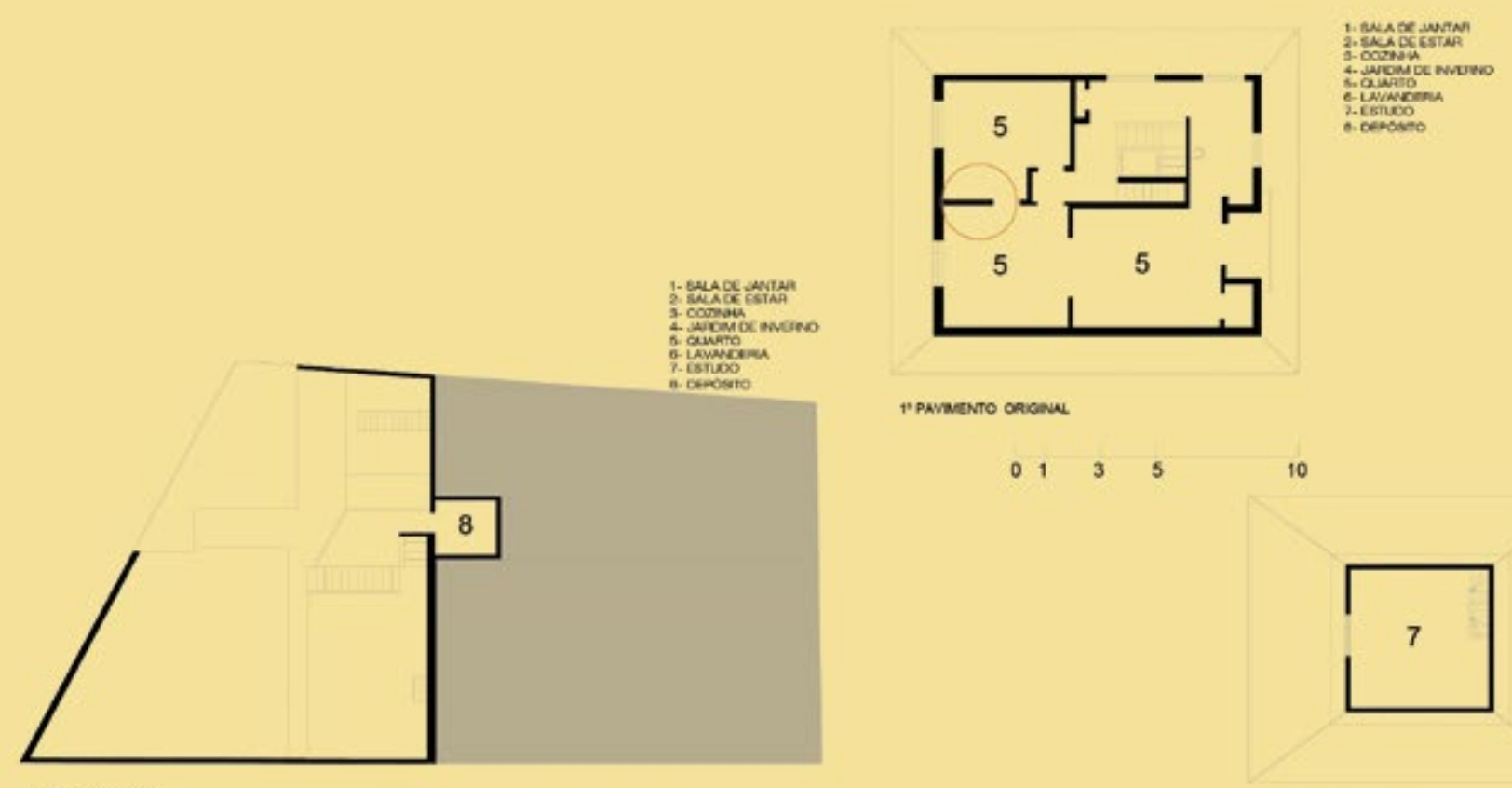

S.s6soco orvanus

10

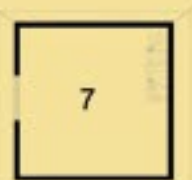

1. SWA of witur i. Whatrom
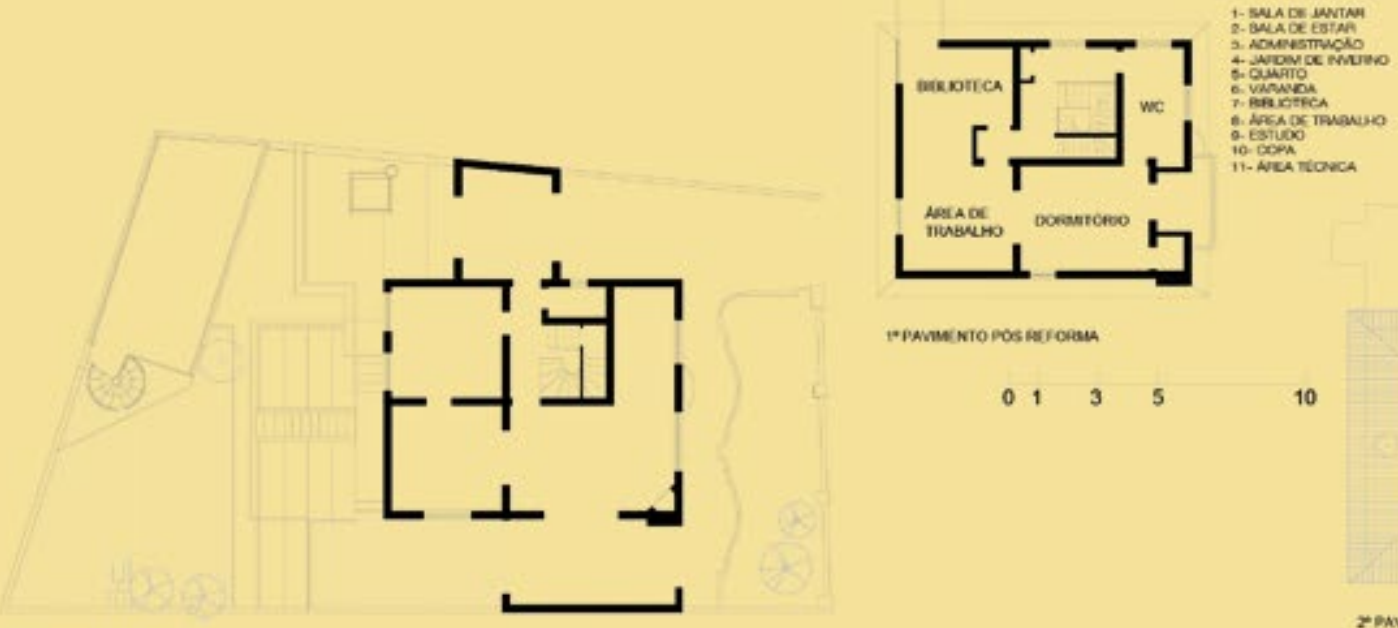

TrReropos arroesu

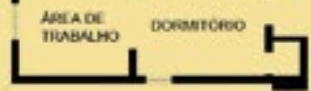

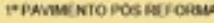

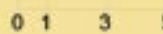

$\begin{array}{lll}0 & 1 & 3\end{array}$

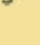

Fenverento pos percesus

0135

10

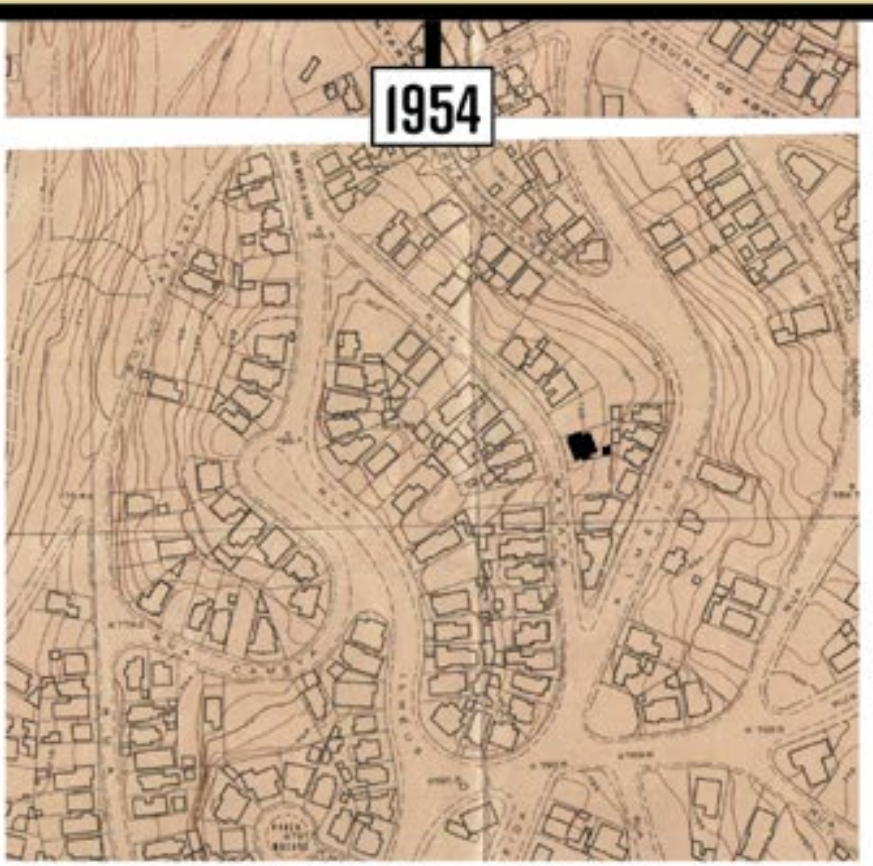

Insersão Urbana
2020
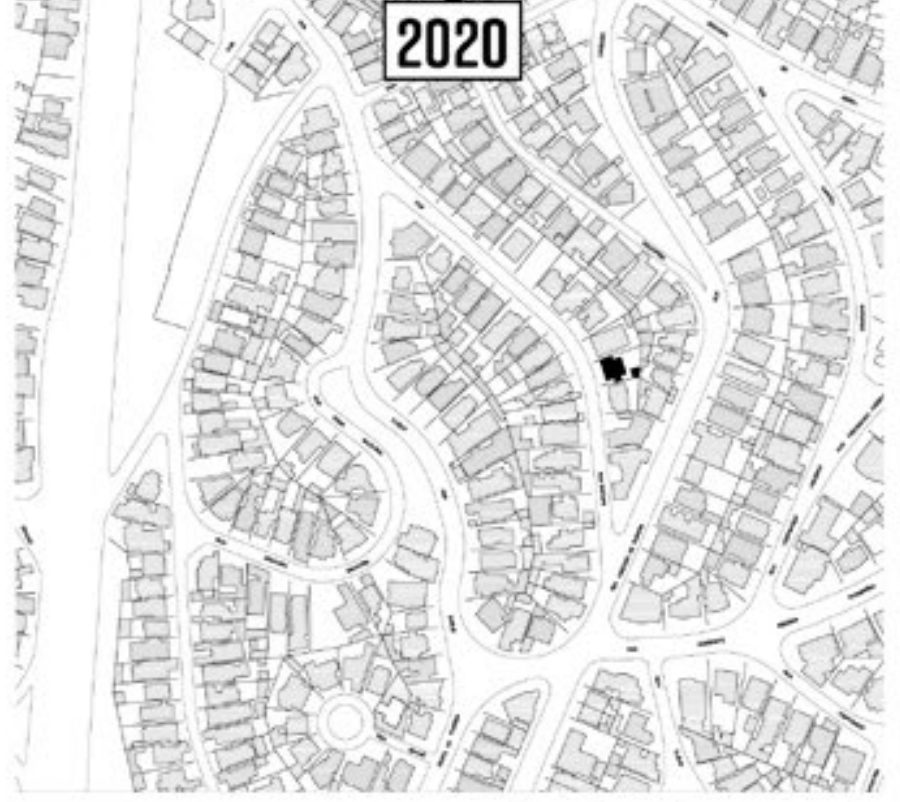

200 

CAPÍTULO 3

\section{POR UM MUSEU DA CASA}

Neste capítulo busco desnaturalizar a arquitetura da casa-museu ao analisar estudos de caso que a contemplam como documento de extensa e complexa rede de relações de produção da cidade, dado material arquitetônico e de sua articulação com o urbano adotado como dimensão simbólica. Verifico aqui como o processo de musealização destas casas se esquiva da intenção de criticar uma edição edulcorada sobre a vida do homenageado, por promover o esquecimento ativo da arquitetura e, também, agenciar a heroicidade de personagem, espaço museal doméstico e, em certos exemplos, de criadores em distintas áreas, a incluir literatura, música, teatro, cinema, artes visuais ou arquitetura.

\section{Desnaturalizando a casa-museu}

Às casas-museu acorrem diversos públicos, fonte de dados que baseiam projetos museológicos e políticas institucionais a atestar que, frequentemente, o visitante da casa-museu é movido pela biografia do homenageado e, não raro, a visita uma única vez. Inúmeras motivações justificam a procura, entre as quais, na perspectiva voltada à humanização do mito, pelo conhecimento dos espaços em que orbitou na sua vida privada, ou interessado na coleção exposta. Esta compreende grande variedade, seja de objetos de arte, quadros, tapetes, mobiliário que revelam o gosto, a operar a inserção da personagem em grupo social específico por meio de escolhas materiais, contextualizando a figura, corroborando ou desafiando a compreensão de uma dimensão pública da vida, ou, ainda, atraído pela exemplaridade da edificação inserida na historiografia arquitetônica. Casas-museu se valem frequentemente da ação cultural expressa em programação de eventos como concertos, palestras, exposições temporárias, embora raramente em rede com outras instituições e equipamentos culturais.

Nas casas-museu, usualmente, como já apontado neste trabalho, arquitetura e recomposição dos ambientes domésticos reafirmam uma narrativa proposta pelo projeto museológico, cujos objetivos, por força de procedimentos específicos referentes à citada disciplina, se sobrepõem à materialidade à custa de viabilizar enredos. Para além das hipóteses relativas aos motivos que trazem visitantes aos museus, 
verificadas e listadas pelas investigações da Museologia, interessam a esta pesquisa características emanadas pela natureza alusiva ao objeto casa, próprias ao âmbito da Arquitetura e Urbanismo, contemplados em múltiplas escalas das quais a casa-museu é documento.

Arranjo interno, distribuição, percursos, usos dos materiais, móveis, objetos e adornos informam hábitos, cultura e arquitetura, situando a personagem homenageada em determinado grupo social e informando, por meio das técnicas, as relações de produção do período da construção. A solução de implantação no terreno, seus recuos, orientação e cotas de nível inferem a relação de vizinhança estabelecida com entorno imediato a constituir, configurar e significar o bairro, unidade de proximidade onde se desenrola a vida cotidiana. Contribuem estas categorias à construção de identidade espacial de cada bairro. A localização da casa e sua inserção na malha urbana evidenciam processos de conformação da cidade e os procedimentos utilizados na urbanização. Considerando-se que, na América Latina, a cidade vem sendo, como aponta Angel Rama, "[...] um parto da inteligência", ou a encarnação de um sonho de ordem fazendo-se o lugar central na edificação, em especial na era capitalista, embora o sonho de cidade, no caso brasileiro, tenha sido substituido pelo que Darcy Ribeiro ${ }^{86}$ chamou de "contraparte dialética do projeto colonial", representada pelo crescimento anárquico e socialmente irresponsável dos núcleos urbanos, a obrigar improvisações que deem conta desta realidade. Embora as instituições públicas dedicadas ao planejamento das cidades historicamente não sejam recentes, desde a implantação da cidade da Bahia, capital da colônia no Brasil'7, a formação das cidades brasileiras sempre esteve além das suas instâncias normativas.

Os estudos de caso que apresento neste capítulo referem-se a duas casas-museu paulistanas, a casa Guilherme de Almeida, no Sumarezinho, e a sede da Fundação Maria Luísa e Oscar Americano, no Morumbi. O primeiro, focado no binômio casa-museu e domesticidade analisa a espacialidade a serviço da estratificação do enredo, por meio de projeto arquitetônico que altera elementos da casa para favorecer a sua acessibilidade e de museografia, que reserva espaços específicos a diferentes traços da personalidade do escritor. Já no caso

86. Darcy Ribeiro (1922-1997), formado em Ciências Sociais na Escola de Sociologia e Política de São Paulo, em 1946, construiu uma brilhante carreira intelectual de projeção internacional, notadamente nas disciplinas Antropologia e Etnologia. Destacou-se como escritor, educador e político, além de ter sido figura presente nos momentos políticos da segunda metade do século XX. Foi senador da República, entre 1991 e 1997, e membro da Academia Brasileira de Letras (Ribeiro, 2015).

87. Antônio Risério em seu A cidade no Brasil (2012), dedica capítulo específico ao processo de normatização da construção em Salvador, no século XVII 
da sede da Fundação Maria Luísa e Oscar Americano procura-se identificar o potencial de narrativa sobre o tempo, indicativo de momento histórico, período local, igualmente incidindo em sua condição específica de momento latino-americano. Os exemplares considerados neste capítulo encontram-se ambos em áreas da cidade de São Paulo cujas restrições edilícias estabelecem densidade mínima, permitindo a construção de uma residência unifamiliar ${ }^{88}$ por lote urbano, com restrições de gabarito, taxa de ocupação, recuos e coeficiente de aproveitamento para além do uso, característicos dos chamados bairros-jardim. Estas áreas, muito valorizadas e centralmente localizadas na metrópole paulistana, oferecem-se como barreiras à mobilidade urbana e têm se caracterizado pela resistência organizada, por meio de agenciamento político com viés ambiental, ao processo de adensamento almejado nas diretrizes dos recentes planos diretores que preconizam a multifuncionalidade e o adensamento em áreas centrais e com ampla oferta de infraestrutura, como meta de qualificação do espaço urbano. A legislação municipal em vigor prevê pouquíssimas atividades não residenciais consideradas aptas ao impacto que geram em certas vias públicas destas áreas, entre elas a instalação de museus ${ }^{89}$.

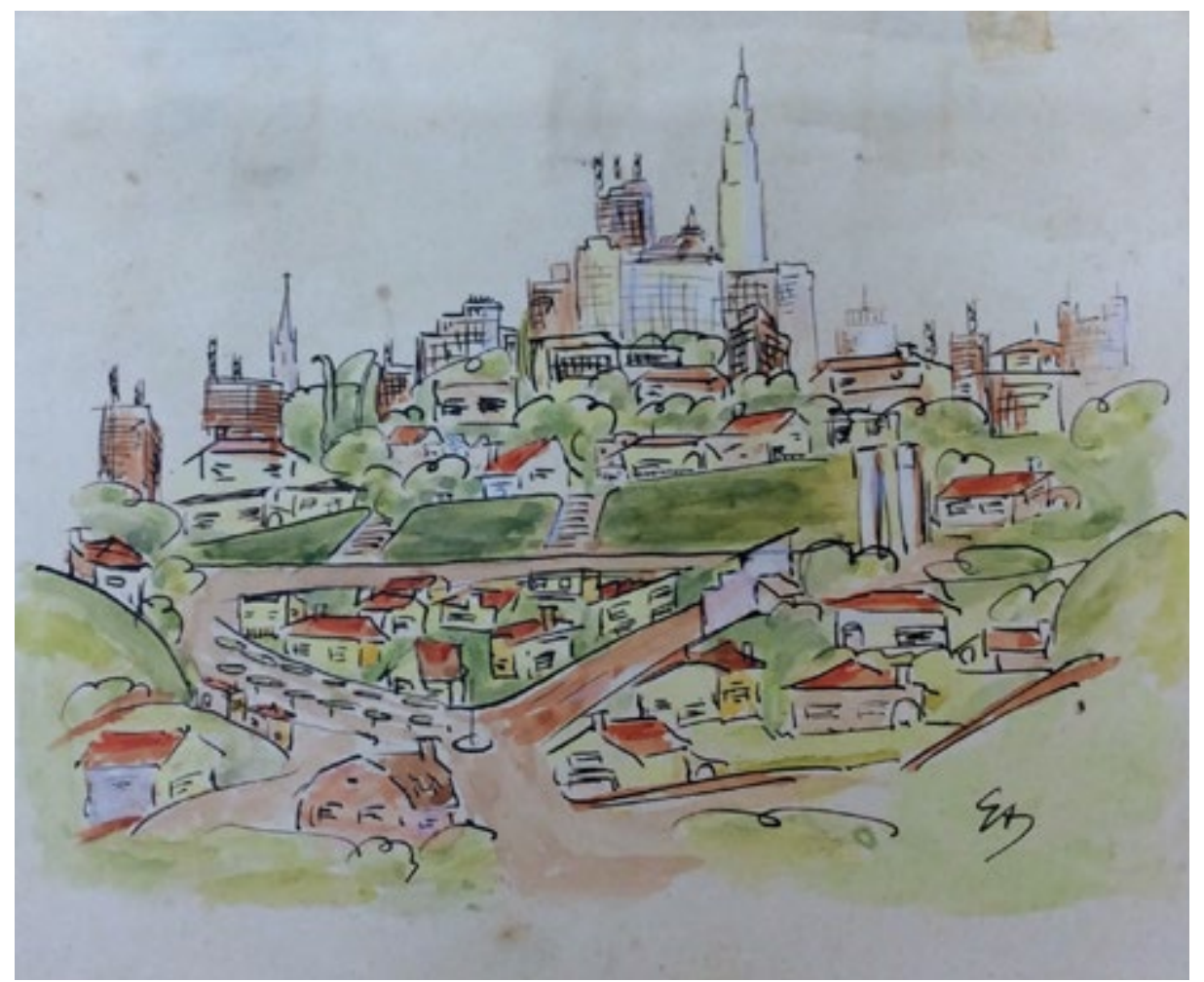

88. Categoria denominada Zona Estritamente Residencial (ZER).

89. Contribuiu para formulação de questões nesta investigação no âmbito dissociação entre museus e cidade o debate proposto pela tese de Renata Vieira da Motta Museu e cidade: o impasse dos MACs, no escopo dos museus de arte contemporânea (2009).
Fig. 22 - Vista do bairro do Pacaembu a partir da janela da mansarda. Guilherme de Almeida. Aquarela sobre papel canson. Década de 1940. Arquivo Casa Guilherme de Almeida. 


\section{Casa Guilherme de Almeida, São Paulo, SP}

\section{Casas-museu e domesticidade}

Frequentemente, a constituição de casas-museu está a serviço da afirmação de identidades, sejam elas nacionais ou de âmbito mais local, como os museus históricos. Para Magaly Cabral, neste sentido, "[...] a casa-museu é uma subcategoria do museu histórico"90 (2003, p. 60). Em 1974, período em que a musealização de casas era ainda incipiente, a ideia, nunca concretizada de fundar um Museu do Modernismo foi aludida como motivação para a argumentação oficial na justificativa de compra da residência e pertences que compunham o ambiente da casa em que viveu o poeta Guilherme de Almeida. Esta carta oficial atesta o afirmado anteriormente relativo ao protagonismo sobre enredo e construção de uma materialidade que justifique a transformação da casa de Guilherme de Almeida em museu.

Fig. 23 - Casa Guilherme de Almeida, São Paulo, SP. Fachada. Foto A.

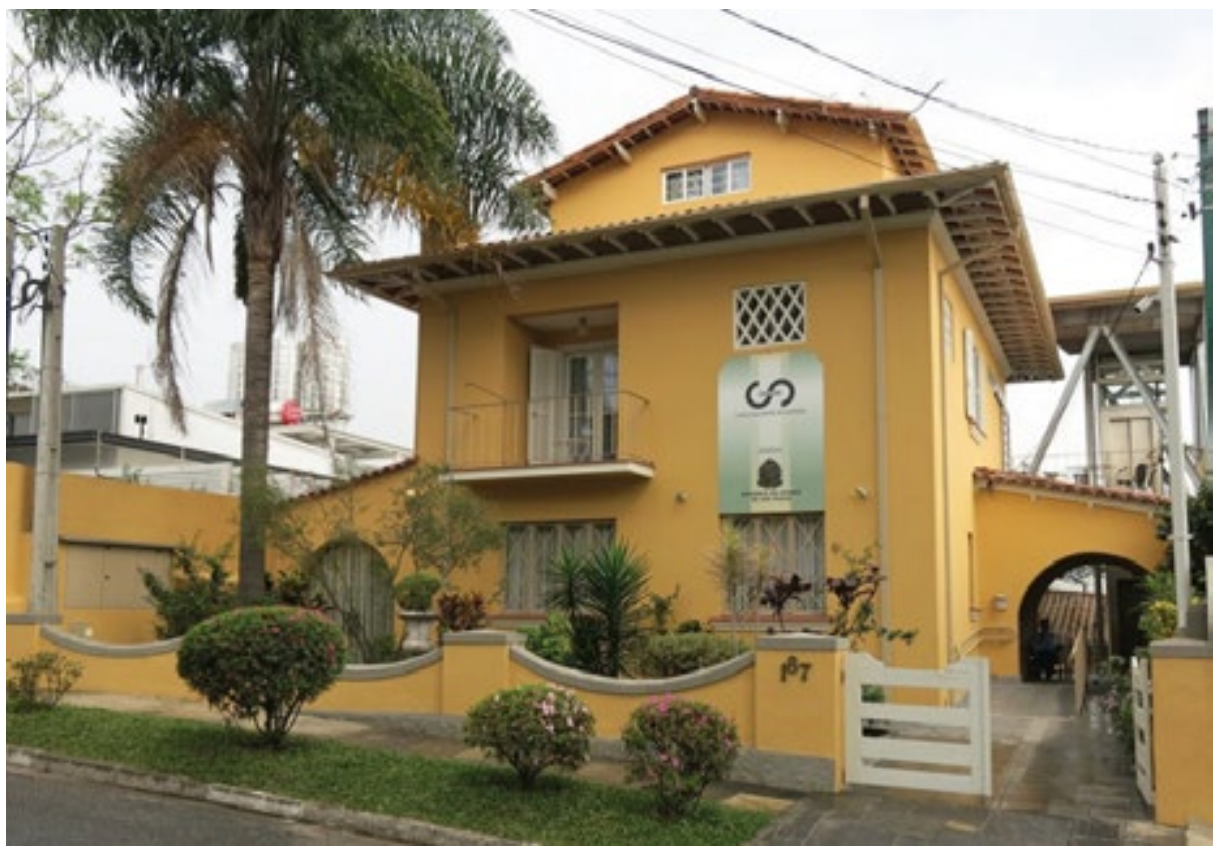

Excelentíssimo Senhor Secretário, é intenção de Vsa. Excia., criar nesta capital, por sugestão da Câmara de Letras do Conselho Estadual de Cultura, o Museu do Modernismo. Perpetuará, esta instituição, na metrópole em que o movimento modernista eclodiu, em 1922, a lembrança desse evento fundamental na nossa evolução estética. Através dele, poderão as gerações jovens dispor harmonicamente de um conjunto orgânico de documentos, atualmente dispersos, e

90. $\bigcirc$ artigo, de autoria de Magaly Cabral, "The role of Historic House Museum in Local and National Identities: the House of Rui Barbosa" foi apresentado à 3a Conferência Anual do Demhist, em outubro de 2002, em Amsterdam, cujo tema era Historic House Museums as witnesses of National and Local Identities. 
que incumbe às entidades culturais do Estado preservar, relativos aos idealizadores e participantes da famosa "Semana".

Nesta ordem de ideias, não poderia haver acervo de maior valor que o deixado pelo poeta Guilherme de Almeida, uma das principais figuras do movimento de 1922. Acumulados em sua residência da Rua Macapá no bairro do Pacaembu, os móveis, quadros, objetos, livros, originais fotografias, correspondências e demais peças colecionadas constituem um raríssimo conjunto do maior interesse para a cultura nacional. Todavia, no caso de Guilherme de Almeida, dadas as características pessoalíssimas da residência em que viveu e trabalhou durante longos anos, o próprio imóvel deveria ser desapropriado, a fim de que a mansarda do poeta, cenário amorosamente por ele composto, se preservasse intacta a exemplo de tantas residências ilustres, conservadas na Europa, nos Estados Unidos, e de que há magníficos exemplos também entre nós, como a casa de Rui Barbosa no Rio de Janeiro. ${ }^{91}$

A edificação na rua Macapá, construída em 1944, pode ser identificada como um exemplar remanescente de certa arquitetura, por possuir traços da linguagem neocolonial simplificada, predominante na ocupação de bairros paulistanos como Perdizes e Higienópolis. Comprada pelo poeta diretamente da Companhia Sumarezinho, responsável pela criação daquele loteamento, a casa estava sendo construída para venda como chamariz da constituição de um bairro a sinalizar um "novo jeito de morar". Guilherme de Almeida recomendou a execução da famosa mansarda, com a intenção de criar um gabinete isolado de trabalho.

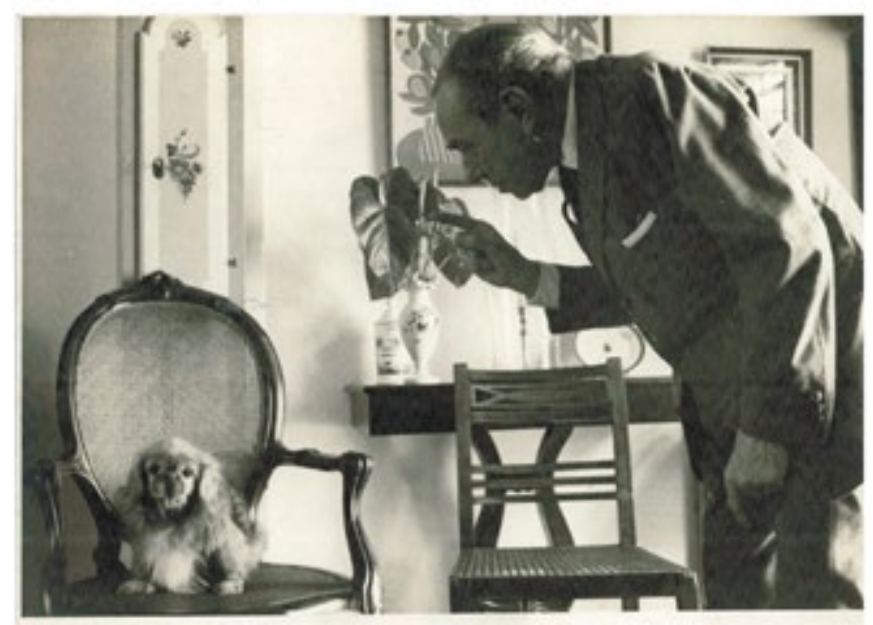

91. Trecho da carta escrita por José Geraldo Nogueira Coutinho, secretário geral do Conselho Estadual de Cultura, pag. 8 do processo de aquisição do acervo do poeta Guilherme de Almeida da Secretaria de Cultura, Esportes e Turismo do Estado de São Paulo - Departamento de Administração, datado de 9 de dezembro de 1974. (Arquivo Casa Guilherme de Almeida)
Fig. 24 - Guilherme de Almeida em casa com seu cachorro Ling Ling, São Paulo, SP. c. 1960. Arquivo Casa Guilherme de Almeida 
Segundo o levantamento feito pelo engenheiro civil José Guilherme de Aranha Moura, em 27/12/1974, que consta no processo de compra da casa pelo Governo do Estado de São Paulo, a casa está situada em um terreno de 360,93 $\mathrm{m}^{2}$, possui quatro pavimentos (contando com subsolo e mansarda) e somando $230 \mathrm{~m}^{2}$ de área construída distribuídas entre subsolo, térreo, primeiro e segundo pavimentos.

O chamado estilo neocolonial, cada vez mais tem sido objeto de estudos acadêmicos ${ }^{92}$, porquanto reflete a produção de período anterior ao da construção da residência de Guilherme de Almeida, na rua Macapá, servindo à análise como representação de um espírito de época em que diversos grupos disputam a autoria daquilo que deveria ser expressão estética da nova brasilidade, nos primeiros anos da República, e nesta busca transita entre o avanço e a tradição, entre o novo e o que se poderia chamar de identitário. É entre estes grupos que circulava, com diferença de poucos anos, Guilherme de Almeida.

Assim como Guilherme de Almeida, Ricardo Severo, pai do neocolonial brasileiro esteve também próximo do Instituto Histórico e Geográfico do Estado de São Paulo (IGHSP), do jornal O Estado de S. Paulo e, com alguns anos de antecedência, foi o arauto da valorização das raízes portuguesas, que mais tarde, no final da década de 1920, resultaria na mitificação do "bandeirante" e todo o imaginário que cercaria o movimento constitucionalista.

A Casa Guilherme de Almeida, como outras casas-museu aqui citadas, reformada em 201093, após quatro anos de fechamento, foi ampliada e teve sua cozinha original suprimida para instalação de áreas administrativas, assim como a eliminação de paredes no andar superior para possibilitar a adaptação da casa às exigências de acessibilidade ${ }^{94}$, por meio da instalação de um elevador. Embora a casa-museu seja uma instituição destinada à uma visitação mais restrita em termos numéricos por sua condição espacial, o regime de funcionamento da Casa Guilherme de Almeida, com frequentes aberturas de exposições

92. Entre os estudos destacam-se a tese de doutorado em Arquitetura e Urbanismo, defendida por Luciana Pelaes Mascaro, na Escola de Engenharia de São Carlos da Universidade de São Paulo, em 2008, intitulada Difusão da arquitetura neocolonial no interior paulista, e o livro da Profa da Faculdade de Arquitetura e Urbanismo da Universidade de São Paulo (FAUUSP), Maria Lúcia Bressan Pinheiro, Neocolonial, Modernismo e preservação do patrimônio no debate cultural dos anos 1920 no Brasil, de 2011

93. Todas as plantas, cortes e elevações referentes à reforma de 2010 constam da dissertação de mestrado que apresentei à FAUUSP, em 2013 (Barbosa, 2013, p. 131-145).

94. Conforme a Norma Federal NBR 9050/94. O atendimento às condições de acessibilidade previstos na norma federal está entre os grandes desafios do projeto de adequação das casas-museu, porquanto sempre implica dimensões e formas de circulação que via de regra não constavam da edificação original. 
e eventos aos quais acorrem públicos específicos, alterou a dinâmica do bairro residencial em que está inserida, obrigando seus dirigentes a negociar frequentemente com a Associação de Moradores do bairro garantias a seu funcionamento.

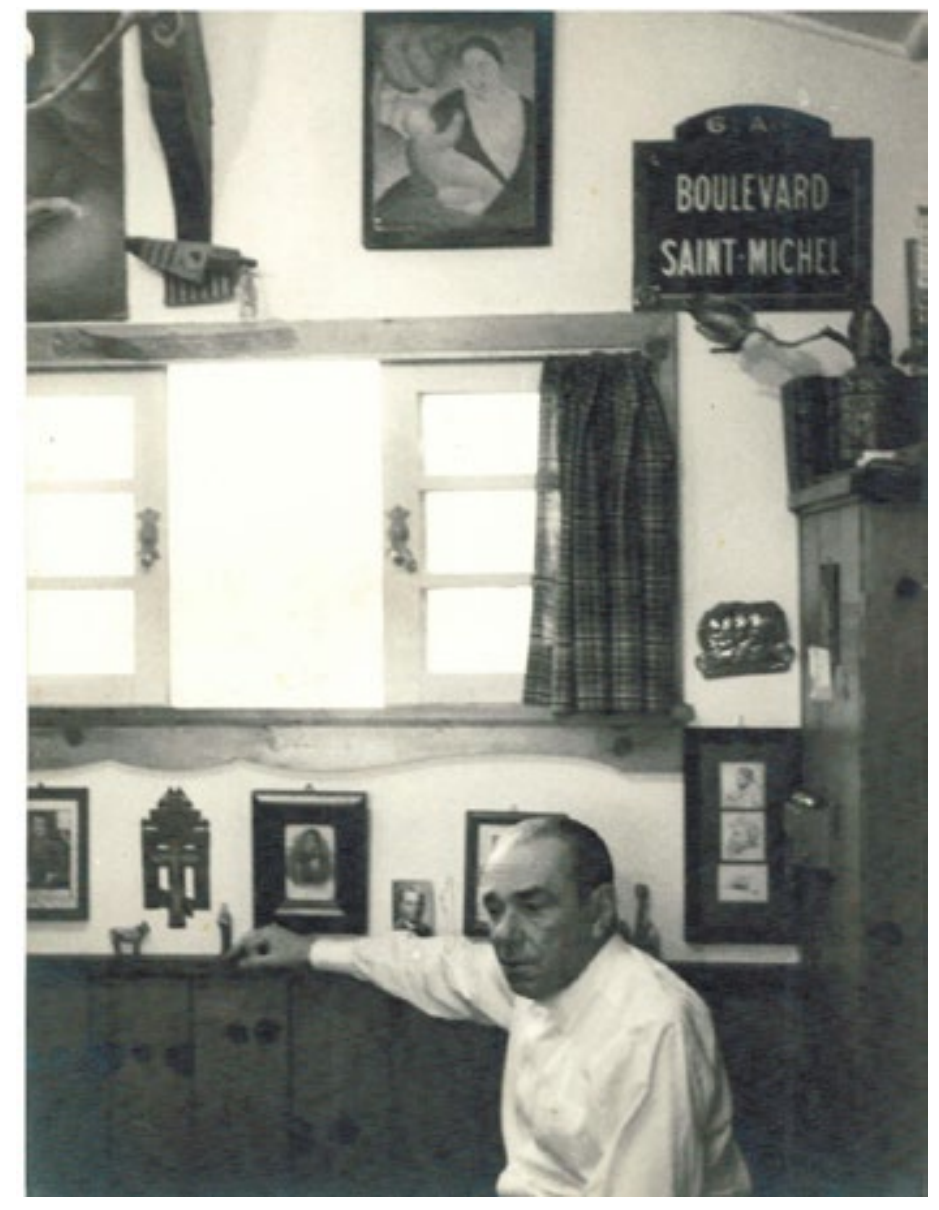

Sua recomposição de espaço doméstico baseou-se em fotografias e no inventário que acompanha o processo de aquisição pelo governo do Estado de São Paulo, fazendo notar que o pavimento térreo valoriza a participação de Guilherme de Almeida no movimento modernista acentuando a exibição de pinturas e esculturas dos anos 1920, na mansarda, objetos do Movimento Constitucionalista dos anos 1930, e o mobiliário percorre datas que atravessam do final do século XIX ao ano de 1970, concorrendo para certa naturalidade na cenarização da vida privada do poeta paulista.

A ocupação dos ambientes da casa, ao reproduzir os espaços domésticos, obedeceu a curiosa estratificação, aludindo no pavimento térreo ao caráter modernista de Guilherme de Almeida por meio das obras de arte de autoria de "Emiliano Di Cavalcanti, Tarsila do Amaral, Anita Malfatti, Antonio Gomide, Moussia Pinto Alves e, entre muitas outras, a célebre escultura Soror Dolorosa, de Victor Brecheret." (Barbosa, 2013, p. 128).
Fig. 25 - Guilherme de Almeida no interior da mansarda, São Paulo, SP. c.1960. Arquivo Casa Guilherme de Almeida. 
Fig. $26-$

Sala de estar da

Casa Guilherme de Almeida musealizada. 2016. Arquivo Casa Guilherme de Almeida.
Fig. 27 - Mansarda musealizada da Casa Guilherme de Almeida, São Paulo, SP. 2016. Arquivo Casa Guilherme de Almeida.

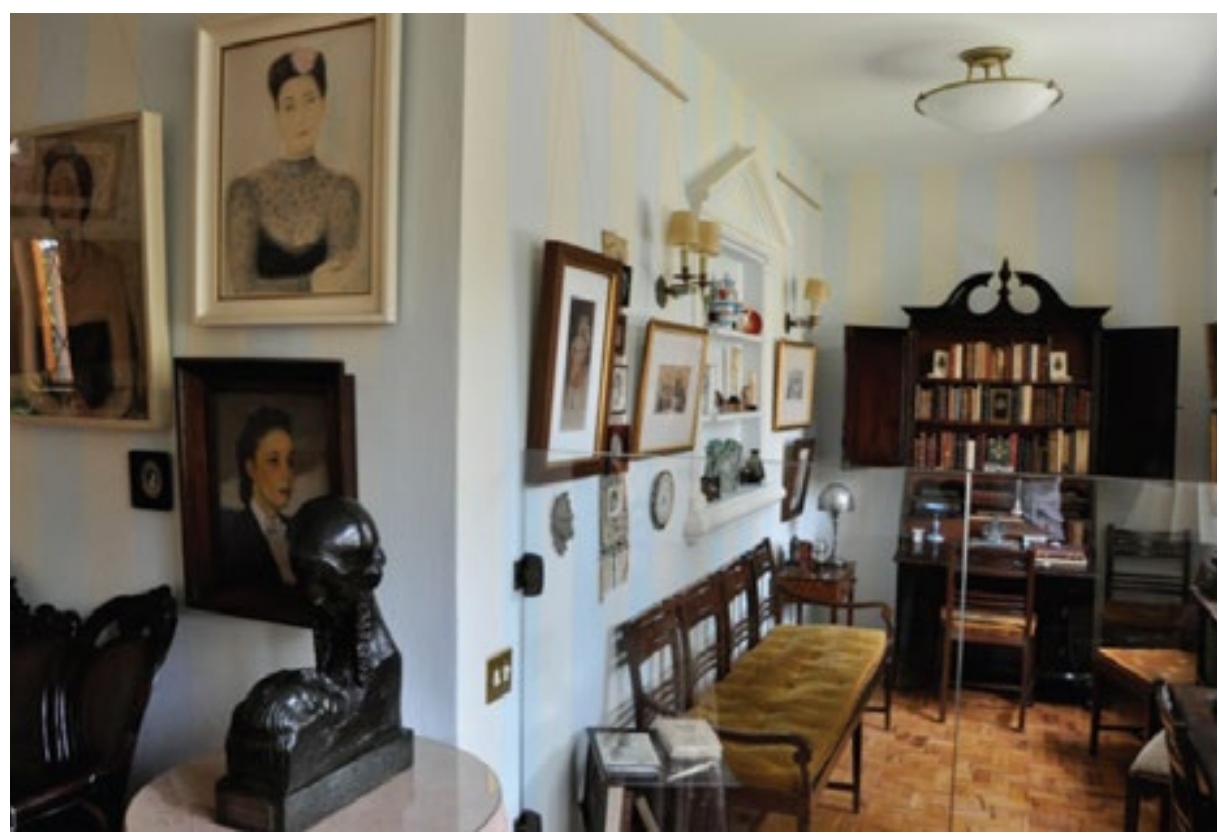

Atente-se ao fato de que a cozinha, situada neste pavimento, foi reformada para dar lugar a área administrativa da casa-museu ${ }^{95}$, reforçando a musealização das casas focada na edição edulcorada da história da personagem, que abre mão do testemunho da arquitetura que a materialidade da casa oferece pelo potencial de ampliar as possibilidades de ação museal, ao revelar o modo de vida e a cotidianidade é preterido em função de resolver outras demandas do projeto.

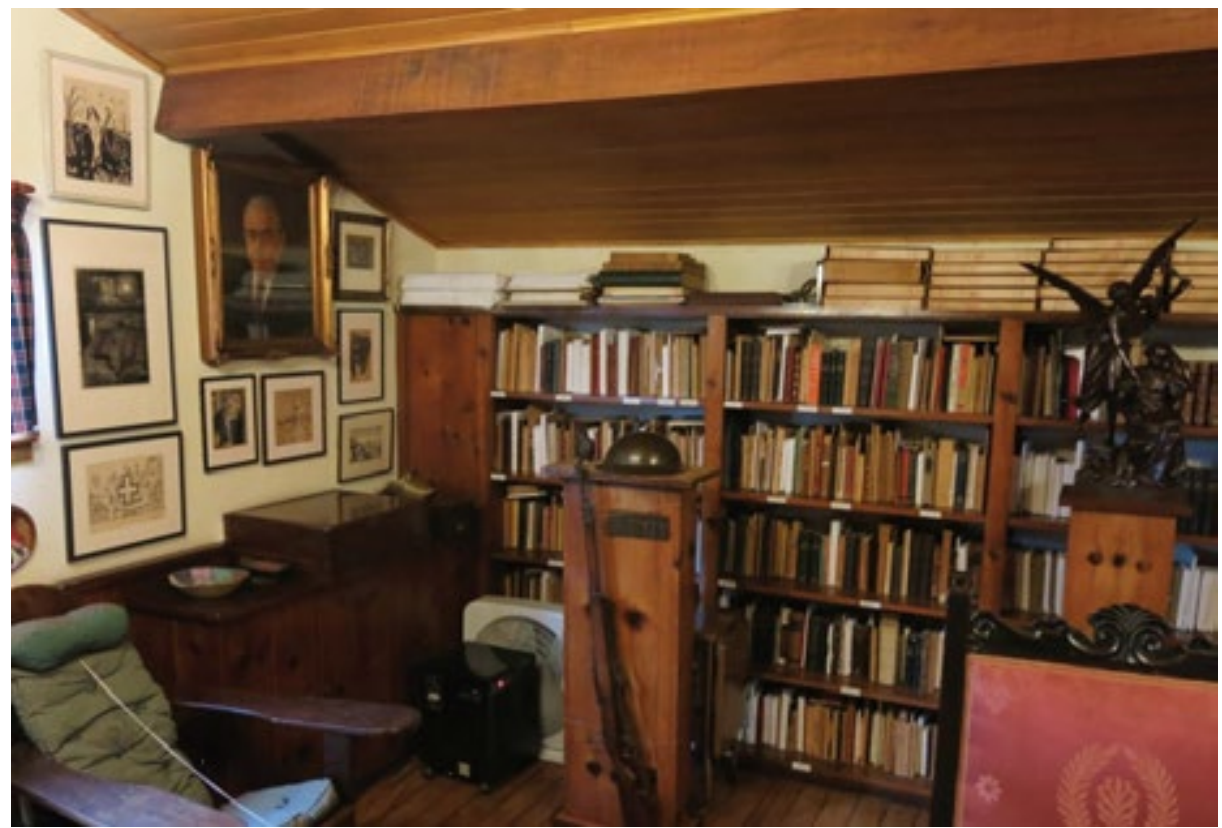

No último pavimento, a mansarda que o escritor mandou construir durante a obra da casa, objetos referenciam-se ao Guilherme constitucionalista, cenografando local denso de elementos ligados

95. A operação de supressão das áreas destinadas aos serviços em casas-museu é frequente como se demonstrará mais adiante nesta tese. 
à participação nos conflitos de 1932, como armas, capacetes, insígnias, além de compor o espaço de escrita predileto do patrono com escrivaninha e máquina de escrever. $\bigcirc$ pavimento intermediário da residência foi o mais alterado por meio da instalação de acesso de deficientes por elevador. A reforma deste pavimento qualificou o espaço com uma biblioteca, aberta ao público mediante agendamento, e restaurou o quarto do casal, destinando o banheiro da suíte ao uso como depósito. O recuo de fundos também teve modificação expressiva para capacitar a ação cultural em área externa.

Desta maneira, expõem-se nesta casa museu, que abriga um Centro de Traduções Literárias, aspectos da personalidade do patrono evidenciados em diferentes pavimentos, por meio da cultura material selecionada. No térreo, Guilherme modernista; no pavimento superior, Guilherme escritor e tradutor; e na mansarda, Guilherme constitucionalista. Modernista que elegeu morar no neocolonial, escolha a ser motivo de pesquisa, ao passo que circulava entre vários arquitetos representativos para o período. $\bigcirc$ projeto da residência é de autoria do engenheiro Silvio Jaguaribe Eckman ${ }^{96}$.

A biblioteca é outro item peculiar das casas-museu, muitas delas pertencentes a escritores e intelectuais, que configura espaço protagonista na ação cultural da instituição, haja vista as existentes na Casa de Rui Barbosa, no Rio de Janeiro; na Casa de Jorge de Lima, em Maceió; na Casa-museu Magdalena e Gilberto Freyre, no Recife; na Casa das Rosas e na Casa de Vidro, sede do Instituto Lina Bo e P.M. Bardi, em São Paulo. No exterior, durante a pesquisa, pude visitar a Maison de Balzac e a Maison Victor Hugo, em Paris, ambas dotadas de extensas bibliotecas. ${ }^{97}$

A supressão de ambientes domésticos para instalação de áreas técnicas ou de exposição é frequente nas casas-museu e operam na expressão significativa criada por Jean-Louis Déotte denominada "esquecimento ativo", ao promover escolhas entre o lembrar e o esquecer. As casas-museu apresentam em sua grande maioria os ambientes sociais da residência da personagem homenageada. Os dormitórios, quando

96. Silvio Jaguaribe Eckman (1900 - 1977), engenheiro formado pela Escola Mackenzie, era filho de Carlos Eckman, responsável pelo projeto da Vila Penteado, uma das sedes da Faculdade de Arquitetura e Urbanismo da Universidade de São Paulo (FAUUSP), a partir de 1948, e mantinha escritório em São Paulo e em Fortaleza, tendo entre suas obras mais destacadas a sede do Ideal Clube da capital cearense, publicada na revista Acrópole (janeiro 1945, ano 7, no 81).

97. Ambas as bibliotecas das casas-museu francesas possuem extensa coleção separada em diversos fundos e guardam raras edições originais, nova edições em todas as línguas além de documentos e trabalhos acadêmicos e críticos sobre os autores homenageados. 0 acervo é disponibilizado de acordo com regras específicas a cada casa. 
exibidos, conferem grau de intimidade almejado na expectativa do visitante. As áreas de cozinha, destinadas aos serviços domésticos e, quando existentes, as acomodações de funcionários da casa são exibidas em casos bastante raros e específicos, como se buscará elucidar nesta tese, predominantemente para atender a uma demanda de conhecimento dos modos de morar do passado. A reconstituição destes espaços responde a alterações no horizonte de expectativas na recepção pelo público, fruto de mobilidade processada por mecanismos voltados à diversificação nas possibilidades de acesso a grupos sociais, outrora ignorados. Acrescente-se que com o passar dos anos, decresce o interesse original na personagem e em seu enredo, e o motivo da visitação tende a se apoiar mais na materialidade da casa e suas potencialidades em testemunhar o modo de vida distinto para dado período.

\section{Entre arquitetura e personagem}

A Casa Guilherme de Almeida é potencialmente exemplar como testemunho da transformação operada na musealização de residências, pois, no momento de sua concepção e construção, com o objetivo de acolher o poeta modernista e sua família, representou escolha fundada na perspectiva de uma cidade em crescimento acelerado pela industrialização posterior ao ciclo cafeeiro, em que famílias abastadas se instalavam em bairros estritamente residenciais, porém, ainda em zonas centrais, num movimento iniciado a partir do final do século XIX, como é o caso de loteamentos executados pela Companhia City, em atividade em São Paulo desde o início do século XX, introdutores do conceito de bairros- jardim a partir das premissas dos urbanistas ingleses Ebenezer Howard e Barry Parker. O bairro em que se situa a nova residência do poeta, feito pela Companhia Sumarezinho, é vizinho do Pacaembu, obra da Companhia City, que se concretizará em grande parte no início dos anos 1950, seguindo o mesmo traçado urbano em curvas que se adequam à declividade do terreno, em contraposição à malha quadrangular de origem pombalina de características homogeneizantes. $\bigcirc$ conjunto de regras edilícias à época se fazia constar em escritura pública, complementando a escassa legislação municipal e garantindo uma atividade estritamente residencial e com recuos obrigatórios ${ }^{98}$ que buscavam um resultado formal de baixa densidade.

98. Durante a pesquisa descobri que o imóvel se tornou irregular perante a Prefeitura Municipal desde que o projeto de musealização cobriu o recuo lateral para incorporar o jardim de inverno no ambiente interno do museu, obra sem possibilidade de aprovação por força da exigência na escritura primitiva do loteamento. Esta situação poderá se alterar em função da Lei de Anistia, aprovada e sancionada em outubro de 2019 pela Prefeitura Municipal de São Paulo e que entrará em vigor no início do ano de 2020. 
Testemunha a residência desta maneira, para além do pertencimento social do seu proprietário, urbanidade vinculada à dinâmica de assentamento no território, deslocado o vetor de crescimento da zona dos Campos Elísios em direção ao oeste cruzando o vale do Pacaembu. O período entre guerras implicou importante desenvolvimento da indústria voltada à construção civil, com adaptações locais, destinada a suprir a crescente demanda por componentes de serralheria e elementos decorativos cuja importação estava restrita.

Guilherme de Almeida faleceu em 11 de julho de 1969, sua casa foi comprada pelo Governo do Estado de São Paulo em 1970 e o museu aberto em 1979, permaneceu durante anos com uma visitação numericamente pouco expressiva, sob agendamento, responsabilidade direta da Secretaria de Estado da Cultura. Uma reforma para adaptação do espaço fez com que ficasse fechado ao público para obras de 1999 a 2004. Reaberto em 2004, é ainda hoje gerido por uma Organização Social (OS), acompanhando a política de parcerias da Secretaria de Estado da Cultura.

Em 2008, o museu passou a ter o anexo na rua Cardoso de Almeida, onde disponibilizaram-se então espaços para cursos, além de área administrativa, reserva técnica e laboratório de restauro. Esta alternativa criadora de áreas funcionais do museu em imóvel vizinho é frequente nas casas-museu, por permitir que os espaços internos não sofram alterações em relação à configuração original na musealização, ou mesmo outro momento escolhido para editar enredo em face do projeto museológico, permitindo inclusive a eventual reconstituição de ambientes domésticos. ${ }^{99}$

Nos arquivos da Casa Guilherme de Almeida há um documento exemplar do debate das casas-museu no que tange aos desafios a serem enfrentados na musealização de residências. Na transformação do espaço para sua capacitação à função museal, o trabalho multidisciplinar, envolvendo Arquitetura e Museologia, tem se mostrado a melhor maneira de atingir um nível de interferência na estrutura física das residências que, ao torná-las acessíveis aos diversos públicos e capazes de realizar os objetivos traçados por planos museológicos, não elimine características que identifiquem os imóveis com seu uso inicial. 
Em ofício datado de 11 de janeiro de $1978^{100}$, a museóloga Waldisa Rússio, à época assistente técnica da Secretaria Municipal de Cultura ${ }^{101}$, assinou a resposta ao então diretor do Museu da Casa Brasileira, ao qual a Casa Guilherme de Almeida se subordinava, que trata da retirada de um armário que dividia dois quartos no pavimento superior da casa. $\bigcirc$ texto itenizado responde à acusação, feita à época pelo diretor, de que a remoção era "[...] obra que modificava a estrutura da casa de modo a desfigurá-la, mesmo que levemente" (1978, p. 27), propondo uma argumentação sob o prisma da museologia e que assume considerar o testemunho histórico, a interpretação adequada e o efeito estético desejado. Assim a museóloga chega à pergunta:

\footnotetext{
que se deve preservar é a casa, o edifício em que viveu o Poeta, ou a casa, em seu conjunto e, sobretudo o espírito que norteou a vida do homem, do cidadão e inspirou sua obra literária e artística? (1978, p. 27)
}

Ao fazer a pergunta acima, Rússio toca no ponto fundamental da musealização destas residências, cujo objetivo, cumprindo os planos museológicos que as apoiam, se incumbe de homenagear uma personagem por meio da cenarização de uma dimensão íntima e privada de sua vida, muitas vezes fetichizada.

Em sua argumentação cita autores como William T. Anderson, Stanislaw Lorentz, Ian Finlay e Gwyn $O$. Jones, que discutem por meio de artigos publicados na revista Museum, no período dos anos 1970, posturas a serem adotadas na conservação e adaptação de casas no caso do Hermitage, casa de fazenda senhorial que pertenceu a Andrew Jackson, sétimo presidente americano, localizada em Nashville, Tenesse, EUA. Essas fontes a permitem afirmar que:

Semelhantemente, o que se deve preservar, na Casa de Guilherme de Almeida, a meu ver, não é um espécime arquitetônico ou um exemplar da casa de um poeta, qualquer que seja ele. Antes, o que se deve preservar e a casa DO poeta Guilherme de Almeida. (Rússio, 1978, p. 28)

E finalmente argui utilizando a comparação entre mausoléu e museu vivo a museóloga afirma que:

100. O processo identificado como DACH - 82.887/77 páginas 26-34, da Secretaria de Estado da Cultura, Ciência e Tecnologia, foi-me disponibilizado durante esta pesquisa nos arquivos da Casa Guilherme de Almeida.

101.Neste período a Secretaria de Cultura do Estado de São Paulo era chefiada por Max Feffer e o governador do estado era Paulo Egydio Martins. 
[...] nosso verdadeiro objetivo de conservação, restauração e interpretação deve ser coerente com o objetivo fundamental de auxiliar o visitante a compreender Guilherme de Almeida como pessoa, cidadão, erudito e poeta. (1978, p. 29)

E, citando exemplos como a casa em que nasceu Hans Christian Andersen, em Odense, a cujo edifício principal se construiu um anexo destinado a abrigar trabalhos de outros artistas, ilustrando a obra do escritor dinamarquês, acréscimos e deslocamentos dos museus Tolstói, na então União Soviética, e reformas de coberturas dos museus diocesanos na Polônia, termina a carta que sucedeu em permissão para a retirada do tal armário que dividia dois quartos que já não continham móveis à época de aquisição do imóvel pelo Estado de São Paulo.

A última reforma, terminada em 2010, demostra a mudança na condução de casos semelhantes ao logo do tempo por parte da Secretaria de Estado da Cultura. A adequação da casa às normas de acessibilidade e segurança por meio da instalação do elevador implicaram em importante alteração na estrutura da casa, na distribuição do espaço interno e em sua fachada lateral.

Charles Summarez Smith discute o poder superior dos museus e defende a transparência nos critérios de exposição e de montagem de acordo com os preceitos da Nova Museologia ${ }^{102}$, no final dos anos 1980. Os documentos relativos às alterações por que passou o imóvel da Casa Guilherme de Almeida constituem ferramenta de compreensão de processos urbanos, entre eles a mudança nos parâmetros de aprovação de procedimentos relativos à preservação patrimonial.

O funcionamento do museu subverte o uso estritamente residencial previsto para a casa no bairro embora esta nova função do imóvel implique em negociar frequentemente com associações de moradores e vizinhos a procura de viabilizar suas ações. Assim, estabelece, por meio de sua atuação, uma nova cartografia do bairro a construir outras urbanidades, desafiando a condição de trincheira

102. No contexto das profundas alterações promovidas em instituições europeias e norte-americanas, nos anos 1960, o Museu passa a ser visto como importante ferramenta de realização do projeto e do ideal político de democratização cultural e por meio da eleição do Museu e suas práticas como espaço de reflexão teórica e epistemológica. Entre os autores centrais a este debate estão Georges H. Riviére. A denominação Nova Museologia, entretanto, surge na Declaração do Quebec, em 1984, cujo subtítulo é: "princípios de base para uma nova museologia", na criação do Movimento Internacional pela Nova Museologia (Minom), em 1985, e com a publicação do livro de Peter Vergo The New Museology, em 1989 (Alice Duarte. Nova Museologia: os pontapés de saída de uma abordagem ainda inovadora. Revista Museologia e Patrimônio, PPG-PMUS Unirio/MAST, vol. 6, nำ1, 2013). 
urbana garantida pelo agenciamento da associação de moradores do bairro, interessada na manutenção de privilégios na utilização do território da cidade, utilizando para tanto, argumentos centrados na preservação ambiental.

\section{Rede de museus literários}

A Secretaria de Cultura e Economia Criativa do Estado de São Paulo promoveu a formação da Rede de Museus-Casas Literários ${ }^{103}$ de São Paulo, composta pela Casa Guilherme de Almeida, Casa das Rosas, que abriga o acervo literário do poeta Haroldo de Campos, e Casa Mário de Andrade. A articulação destas três casas em torno de um tema potencializou suas gestões e atuações para seus públicos. Hoje a rede congrega outras seis instituições que veem muito ampliadas suas possibilidades de atuação nas comunidades que atendem.104

A formação de redes de museus ${ }^{105}$ em torno de temas comuns é uma estratégia capaz de equacionar a articulação premente na atualidade, a saber, entre as dimensões global e local como preconizadas por Stuart Hall, na medida em que possibilitam tensionar a atuação singularizada por meio de vieses exógenos, livrando-as da pejorativa rotulação de depósitos a que as instituições museais são frequentemente submetidas, dados seus desempenhos limitados, qualificando suas relações com públicos diversificados. Ademais as redes propiciam profícua produção e troca de conhecimentos, técnicas e procedimentos entre membros, aprofundando questões específicas levantadas em outras redes mais genéricas, como, por exemplo, a do Sistema Estadual de Museus (SISEM-SP) ${ }^{106}$ ou do Instituto Brasileiro de Museus (IBRAM).

A Casa Guilherme de Almeida, localizada em bairro nobre da capital paulista, tem dimensões modestas quando comparada à casa-museu

\footnotetext{
103. http://www.museusliterarios.org.br/ Acesso em 15/01/2018

104. Conforme entrevista realizada com o Marcelo Tápia, diretor da rede de museus literários de São Paulo na Casa Guilherme de Almeida em 12/11/2019.

105. Ver a tese de doutoramento de Ana Cristina Carvalho defendida na Escola de Comunicações e Artes da Universidade de São Paulo - ECAUSP no Programa de Pós Graduação em Artes Visuais em 2008 "Gestão do Patrimônio Museológico: As Redes de Museus".

106. O Sistema Estadual de Museus - SISEM SP foi criado em 1986 por meio do Decreto $n^{\circ}$ 26.634, assinado em 13 de janeiro pelo então Governador Franco Montoro, pelo Secretário de Estado da Cultura, Jorge da Cunha Lima e pelo Secretário de Governo, Luiz Carlos Bresser Pereira, é o primeiro sistema de museus do país. Juntos SISEM e Demhist, em 2010 promoveram por meio do Acervo dos Palácios do Governo do Estado de São Paulo, curso específico de capacitação aos trabalhadores em casas-museu com a presença de professores estrangeiros.
} 
que analiso a seguir, evidenciando a diversidade do conjunto que a categoria abrange capaz de conferir qualidade ao potencial de documento da relação casa/cidade proposto nesta pesquisa, entretanto, valem-se ambas da musealização da arquitetura e de suas representações para promover projetos estético-político-ideológicos, legados para a comunidade, embora difiram fundamentalmente na composição de seus acervos.

acervo da Casa Guilherme de Almeida, à maneira de outras casas-museu de escritores e artistas, compõe-se de móveis, objetos e obras de arte, que localizam a personagem num universo temporal e num grupo específico vinculado à sua produção artística e intelectual. Diferentemente, a sede da Fundação Maria Luísa e Oscar Americano possui acervo composto parte pela coleção de arte feita pelo casal, a incluir os móveis, e outra, por coleções adquiridas posteriormente à morte de Oscar Americano, fruto de política de aquisição possibilitada por dotação de fundo específico destinado em testamento.

Os registros dos usos deste edifício, concebido originalmente como residência de uso privado e posteriormente utilizado como museu aberto ao público, são documentos que também atestam a dinâmica da cidade. Sua materialidade, para além do enredo proposto pelo projeto museológico que a edita, pode ser objeto a serviço da compreensão do urbano como categoria de pensamento da cidade, como proposto por Henri Lefebvre ${ }^{107}$, pensar o fenômeno urbano a partir da distinção entre sua materialidade, dado arquitetônico e sua expressão conceitual. É assim que a casa, concebida como locus das práticas cotidianas relacionadas à sobrevivência, como sono, alimentação, higiene, lazer e sociabilidade, propiciada por meios técnicos e geratriz de vínculos a atender atavismos humanos, entre estes permanência, segurança, memória, é aqui observada como manifestação material de um processo de transformação. Tais fatores atestam o potencial de representação em escala íntima da mediação entre pessoa e mundo, matizando o olhar propiciado pela disciplina Arquitetura, frequentemente pautado pela valorização do excepcional, do raro, do puro, em detrimento à casa como fenômeno ordinário, cenário do cotidiano.

107.Para Lefebvre "A cidade e o urbano não podem ser compreendidos sem as instituições oriundas das relações de classe e de propriedade." (2016, p. 62). Sua afirmação de que a cidade, embora sempre tenha tido relações com a sociedade no seu conjunto, com sua composição e seu funcionamento, com seus elementos constituintes, com sua história, as transformações por que passou não são resultados passivos da globalidade social, de suas modificações. Ele a situa a meio caminho de uma ordem próxima e outra distante, similar às relações percebidas por Milton Santos ao conceber o jogo de tensão entre verticalidades e horizontalidades. 
Milton Santos afirma que "O território é o chão mais a população, isto é, uma identidade, o fato e o sentimento de pertencer àquilo que nos pertence" (2001, p. 47). A construção desta identidade, por vezes, no caso latino-americano, esteve também à cargo da literatura. Segundo Antonio Candido, no livro Formação da literatura brasileira, de 1959, os autores latino-americanos responderam a uma dupla missão de criar, ao mesmo tempo, uma pátria e uma literatura. Este conceito tem permeado trabalhos acadêmicos acerca da produção literária latino-americana nas chamadas correntes pós-colonialistas que identificam esta construção da ideia de América Latina a partir do campo da literatura ${ }^{108}$. $\bigcirc$ urbano, a urbanidade, são conceitos construídos por meio da representação ${ }^{109}$, incluindo a literatura, o cinema, as artes plásticas e a música.

As casas-museu, espaços de memória instalados em edificações cuja proposta de uso inicial era residencial, ofereceriam contribuição qualificada ao orientar suas ações no sentido de historicizar o fenômeno urbano enquanto documentos da cidade como sobreposição de temporalidades. Santos considera que o espaço se define como "[...] um conjunto de formas representativas de relações sociais do passado e do presente e por uma estrutura representada por relações sociais que estão acontecendo diante dos nossos olhos e que se manifestam através de processos e funções" (Santos, 1978, p. 122). A casa tornada casa-museu, dada a nova função pública a que se propõe, documenta e infere novas relações entre vizinhança e de construção de um território a partir de sinergias a construir paisagens naturais e culturais, instrumentando a aludida resistência às chamadas verticalidades de que fala Santos ao conceber uma nova ordem mundial que relaciona global e local. Para o geógrafo a ordem global serve-se de uma população esparsa de objetos regidos por lei única que os constitui em sistema, característica essencial do período técnico científico e informacional, produtor de verticalidades. A ordem local, à qual reputa uma posição de possível resistência, se refere a uma população contígua de objetos, reunidos pelo território regidos pela interação, denominada de horizontalidades.

Milton Santos opõe as horizontalidades, construídas pelas contiguidades, pelos vizinhos, às verticalidades, expressões de lugares distantes

108. Discussão sobre o tema da literatura baseia-se no artigo de Leyla Perrone-Moisés, "Paradoxos do nacionalismo literário na América Latina", publicado na Revista de Estudos Avançados da USP, v. 11, no 30, 1997.

109. Roger Chartier analisa práticas e representações tendo como objeto de estudo o livro, e afirma o protagonismo da forma na construção dos sentidos. 
que se ligam por formas e processos sociais afirmando que "[...] os territórios são formas, mas o território usado são objetos e ações, sinônimo de espaço humano, espaço habitado." (2012 B, p. 38).

São muitas as escalas das quais a casa-museu é documento. Desde aquela dos ambientes domésticos, em que sua organização, percursos, funções, mobiliário e equipamentos atestam gosto e universo de pertencimento social dos moradores, passando pela escala de sua implantação no lote, determinada por posturas edilícias municipais. Estas objetivam garantir densidades determinadas aos bairros, a desenhar o mapa socioeconômico das cidades, até a escala regional expressa nas soluções técnicas e de enfrentamento das condicionantes de projeto, concernente à materialidade disponível.

No centro da experiência urbana contemporânea e sintoma da profunda transformação por que o urbano, como categoria de pensamento da cidade apresenta, encontram-se as instituições culturais voltadas à preservação de memórias, entre elas, os museus, aos quais se reputa na atualidade, papel central na sedimentação de identidades, capaz de atenuar processos de desterritorialização, de desculturação, elencados por autores como Milton Santos, Marc Augé e Stuart Hall, como motores de profunda alienação do homem urbano contemporâneo.

É preciso debater aspectos que possam contribuir à compreensão de práticas, relações e procedimentos utilizados por estas instituições no intuito de realizar suas potencialidades construindo relações com distintos segmentos sociais em diálogos e trocas. Não estariam museus, centros de memória e, mais especificamente, as casas-museu, anacronicamente, aderidos a modos de visualização do passado expressos em certezas e totalidades que perderam sentido na atual relação que o homem estabelece entre o tempo de hoje e outros tempos?

A virtualidade, a mediar a relação entre habitante e espaço urbano, tem possibilitado uma vivência não presencial da cidade e operado alterações no papel dos museus, desafiando-os a modificar procedimentos em busca de alinharem suas premissas àquelas constantemente redesenhadas pelos órgãos reguladores, entre eles o International Council of Museums (ICOM). Observe-se que esta virtualização, expressa na desmaterialização de percursos e experiências na cidade ${ }^{110}$, tem se afirmado

110. Entre as experiências de virtualização da relação com a cidade encontram-se os inúmeros aplicativos de celulares operando singular transformação na vida urbana restrita a certas camadas como Uber, Ifood, Maps, Tinder, Loggi e outros. 
gradativamente excludente, impondo-se à maneira das verticalidades como afirma Milton Santos, agindo de acordo com uma ordem global que se pretende homogeneizadora, asseverando um sistema de características que definem um período técnico-científico-informacional que está expresso inclusive em práticas museais, a atuar mais como diafragma entre público e acervo que propriamente instrumento de mediação.

Neste cenário, a resistência plausivel a esta uniformização buscada pelas tais verticalidades se opera, entre tantos, em lugar, dinâmica da ordem local, relações de contiguidade, vizinhança, escalas em que certas articulações promovidas por instituições de memória tem um tributo essencial. Igualmente contribuem decisivamente na construção de identidades e oferta de probabilidades de conexão entre memórias individuais e coletivas profundamente alteradas pelo ritmo dos ciclos contemporâneos.

Na compreensão dada ao fenômeno da globalização e sua relação com as identidades culturais, Stuart Hall alertou para a complexidade destes processos considerando que "[...] ao invés de pensar no global como substituindo o local seria mais acurado pensar numa nova articulação entre o global e o local" (2006, p. 77). Ao examinar a aceleração dos fluxos culturais contemporâneos sobre as identidades nacionais, Hall observa três possíveis consequências: sua desintegração como resultado da homogeneização cultural, seu reforço pela resistência à globalização e seu declínio ou substituição por novas identidades híbridas que tomam seu lugar.

Ao analisar o que denomina o impacto da globalização sobre as identidades culturais, Hall afirma que tempo e espaço são coordenadas básicas para todos os sistemas de representação e são categorias profundamente alteradas pelos processos em curso, transformando profundamente a forma como as identidades são localizadas e representadas. Segundo Hall, todas as identidades estão localizadas no espaço e tempo simbólicos e possuem suas geografias imaginárias, "[...] seu senso de lugar, de casa/lar, ou Heimat ${ }^{111}$, bem como suas localizações no tempo" (2006, p. 71), que seriam tradições inventadas a ligar passado e presente expressas em mitos e narrativas que conectam memórias individuais às coletivas. Desta forma, propõe o autor que as identidades têm se tornado mais e mais desvinculadas

111. Heimat é uma palavra alemã que, embora não tenha tradução exata para o português, significa pátria, lar, lugar onde se nasceu e foi criado. Na Alemanha, Heimat assume significados de delimitação social, tornando-se um referencial para movimentos nacionalistas para os quais a Heimatschutz (proteção da Heimat) é uma defesa contra o multiculturalismo e os refugiados. Disponível em: <https://www.dw.com>. Acesso em: 12/06/2016. 
de tempos, lugares, histórias e tradições específicas à medida que o mercado de imagens e comunicação global mediam a vida social.

Entre os fenômenos apontados por Stuart Hall produzidos pela tensão entre global e local, estaria a fascinação com a diferença expressa na mercantilização da etnia e da alteridade como nichos de mercado, a incluir o de arte. A ideia de que as sociedades periféricas do capitalismo tardio são puras e culturalmente tradicionais e intocadas não seria senão uma "fantasia ocidental sobre a alteridade, uma fantasia colonial sobre a periferia" (2006, p. 80), a negar que as bordas do sistema também estão sujeitas aos seus efeitos pluralizadores. A proposição de Hall centra-se na instabilidade a que se sujeitam de maneira articulada as identidades culturais submetidas a alteração das noções e práticas de tempo e espaço, e o que se pretende aqui é oferecer a este debate certas alternativas de atuação da casa-museu, modelo específico de instituição museal, e suas articulações com outras instituições na malha da cidade.

De que maneira a virtualização da experiência urbana poderia ser cooptada no processo de sedimentação identitária inferido pela casa-museu? A recepção, fenômeno socialmente constituído, alterada por esta nova configuração, demanda do museu novas camadas de leitura de seus acervos e de relacionamento com a cidade a alcançar os objetivos contidos na missão do ICOM. Como torná-lo mais acessivel, democratizante, lançando mão de novas tecnologias dada a lógica excludente que as produz?

Em Milão, na Itália, as casas-museu encontram-se mapeadas e georreferenciadas, compondo um site com interatividade bastante amigável contendo informações completas sobre as casas listadas e inseridas na malha da cidade, propiciando entradas diversas de acordo com a demanda do visitante. A iniciativa do site https://casemuseo.it/ testemunha as várias possibilidades de interlocução institucional a serem exploradas entre a casa e a cidade por meio das tecnologias digitais. ${ }^{112}$

Segue a fundamentar a tese da casa-museu como testemunho material da dinâmica da cidade e suas temporalidades o estudo de caso da sede da Fundação Maria Luísa e Oscar Americano no bairro do Morumbi em São Paulo.

112.Agradeço a sugestão desta inclusão à Profa . Dra. Renata Vieira da Mota em Banca de Qualificação deste trabalho. 


\section{FUNDAÇÃO MARIA LUISA \\ E OSCAR}

AMERICANO

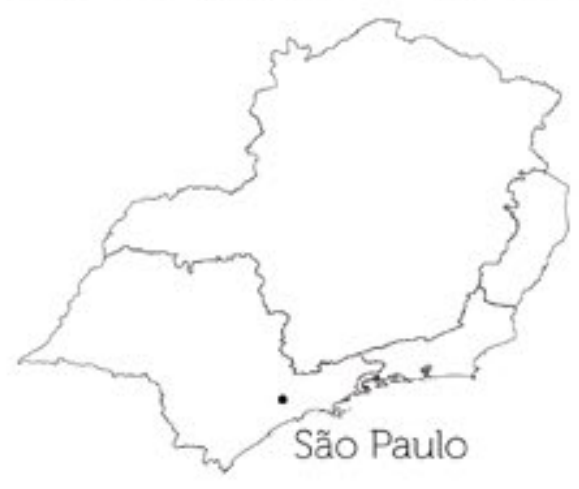

$\begin{array}{ll}\text { Endereço: } & \begin{array}{l}\text { Av. Morumbi, } 4077 \\ - \text { Morumbi }\end{array} \\ \text { Cidade: } & \text { São Paulo } \\ \text { Arquiteto: } & \text { Oswaldo Bratke } \\ \begin{array}{l}\text { Data de } \\ \text { construção: }\end{array} & 1953 \\ \begin{array}{l}\text { Periodo(s) } \\ \text { de reforma: }\end{array} & - \\ \begin{array}{l}\text { Técnicas } \\ \text { construtivas }\end{array} & \begin{array}{l}\text { Estrutura de concreto e } \\ \text { alvenaria de tijolos. }\end{array}\end{array}$

Dados da casa-museu

Inauguração do museu:

1974

Área do terreno: $\quad 75.000 \mathrm{~m}^{2}$

Pavimentos: $\quad T+1$

Área do térreo $\quad 795,26 \mathrm{~m}^{2}$

Área do 1ำ pav: $\quad 800 \mathrm{~m}^{2}$

Área total:

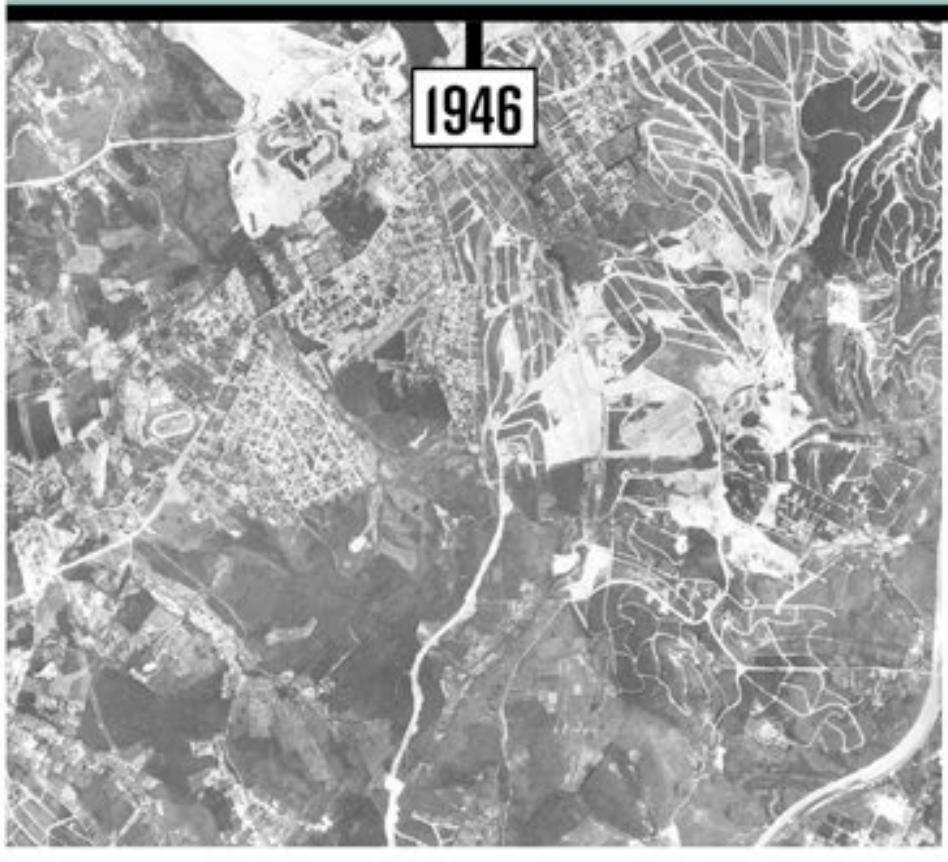

Vista aérea do Morumbi. 


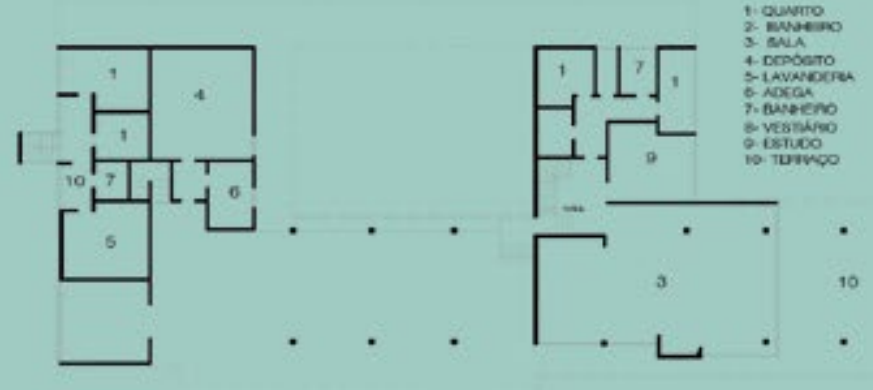

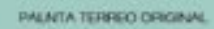
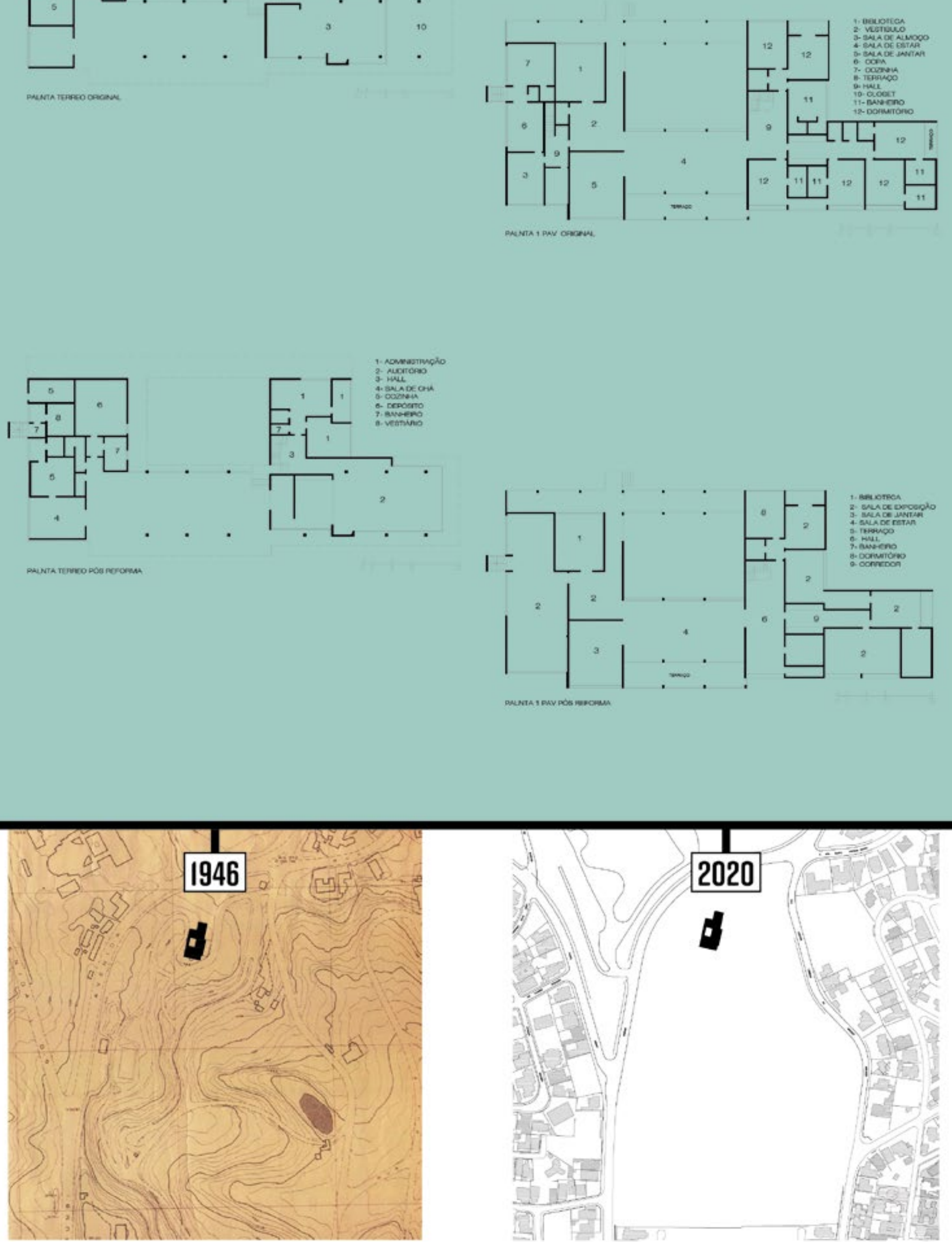

Insersão Urbana
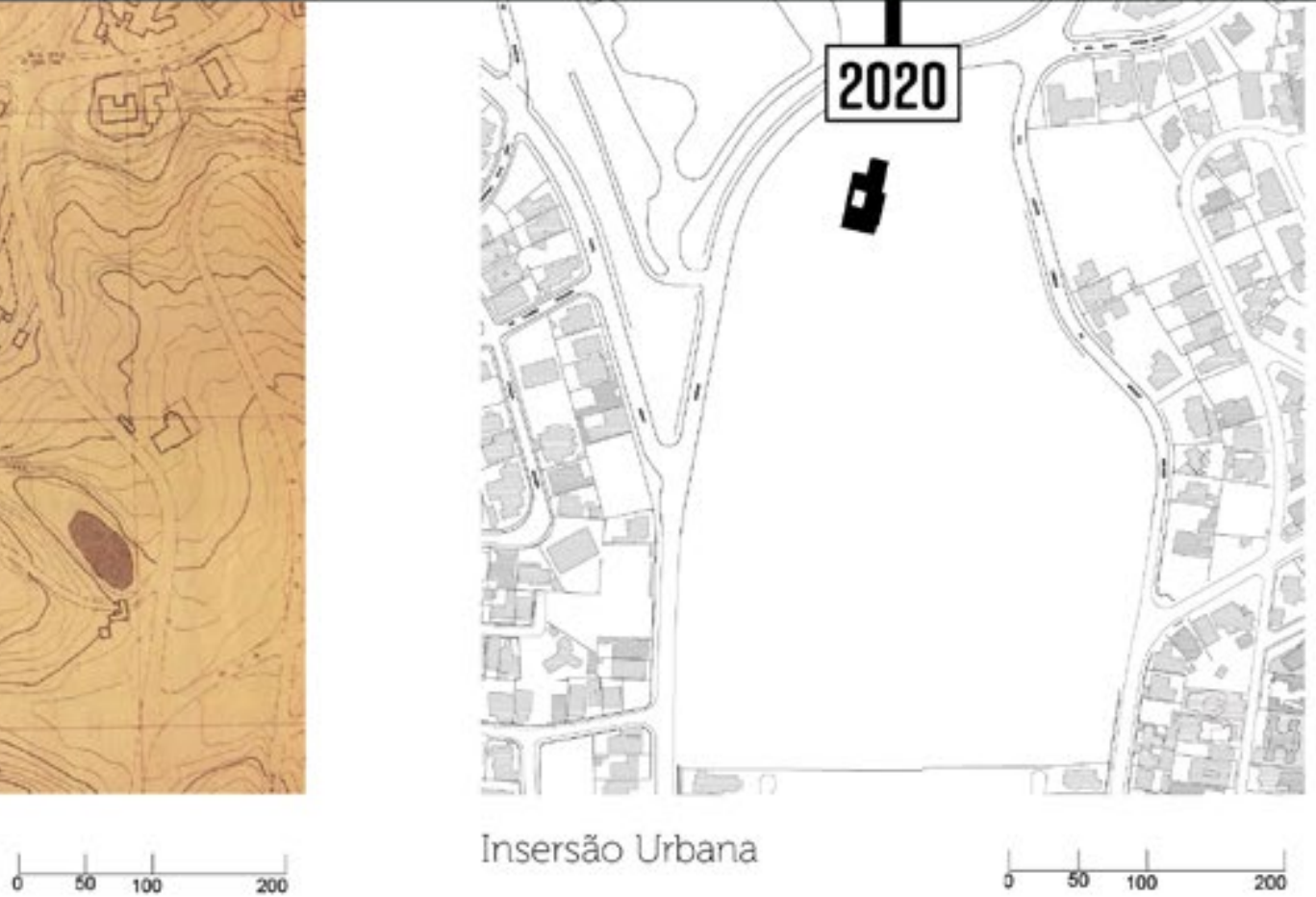

Insersão Urbana

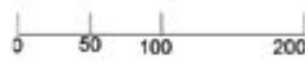




\section{Fundação Maria Luísa e Oscar Americano, São Paulo, SP}

\section{Casa-museu latino-americana}

Nesta casa, arquitetura, coleção e paisagismo, concebidos e executados em âmbito privado no início da década de 1950, tornaram-se públicos em 1974 e, hoje, se expõem à recepção113, esta aqui entendida como composta por distintas interpretações sociais construídas culturalmente e impregnada de seu tempo. $\bigcirc$ universo pregresso do receptor, segundo Hans Robert Jauss ${ }^{114}$, compõe seu horizonte de expectativas condicionado pelas relações de grupo que estabelece, em determinado espaço social, espaço este de tensões em que se determina a posição social dos agentes.

Fig. 28 - Fundação Maria Luisa e Oscar Americano, São Paulo, SP. Fachada. 2017. Foto A.

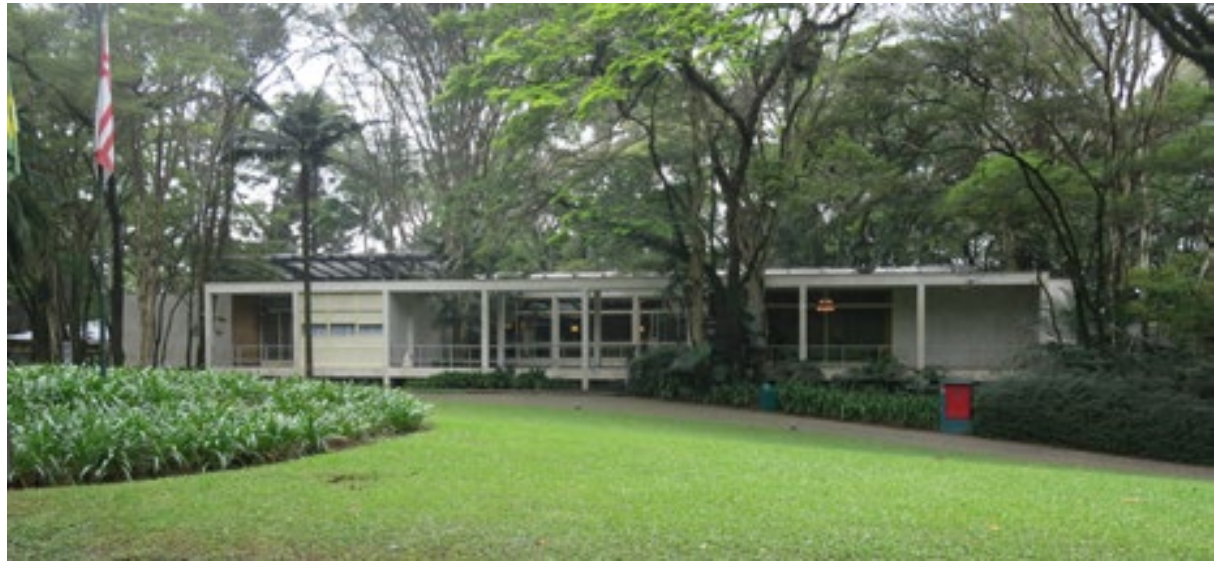

A abertura ao público da sede da Fundação Maria Luísa e Oscar Americano implica em transição da residência à casa-museu empreendida por meio de intervenções que preteriram a salvaguarda voltada a elementos de significativo conjunto com interesse plástico, rico em características identificadas com a expressão do modernismo

113. Conceito que, utilizado por Hans Robert Jauss (1921 - 1997), no final dos anos 1960, possibilitou formular a metodologia da Estética da Recepção destinada à análise da obra de arte, deslocando seu eixo do objeto artístico na direção de sua recepção, associada às distintas interpretações suscitadas.

114. Hans Robert Jauss (1921 - 1977) desenvolveu estudos em Filologia do Romance, Filosofia, História e História e Cultura Germânicas. Foi aluno de Martin Heidegger e Hans-Georg Gadamer e professor de Teoria e História Literária na Universidade de Constança na Alemanha. Em 1967, abriu o semestre letivo da universidade alemã com a palestra "O que é e com que fim se estuda a História da Literatura", em que verifica que nem o marxismo nem o formalismo transpõem o desafio da disciplina e propõe levar em conta a recepção como forma de entender a permanência das obras ao longo do tempo. A partir destes estudos desenvolveu a Estética da Recepção, que altera os critérios de análise da obra literária (Jauss, 1994 [1967]). 
brasileiro associado ao chamado desenvolvimentismo ${ }^{115}$ dos anos 1940-1950. Tal solução favorece a ambientação do acervo dividido em três principais núcleos: Brasil-Colônia, formado por pinturas do século XVII, incluindo excepcional coleção de quadros do pintor holandês Frans Post ${ }^{116}$, e objetos e imagens do século XVIII; Brasil-Império, com retratos a óleo dos membros da Família Imperial portuguesa, objetos e documentos relativos à época; e Mestres do Século XX, com pinturas e esculturas criadas por artistas brasileiros, desde aqueles provenientes de Academias em várias tendências, em especial paisagistas, porém apenas até modernistas. A escolha da composição do acervo evidencia a associação de períodos históricos a certo modernismo brasileiro conferindo-lhe específica historicidade.

À ausência do mobiliário moderno original da casa somam-se modificações diversas na arquitetura, como a troca das luminárias formadas por desenho duplo cônico da fachada por lanternas em diálogo com o período colonial, revestimento de mármore travertino aplicado aos pilares em substituição às pastilhas de porcelana, ou mesmo a mudança da secção circular original dos pilares metálicos do pavilhão da piscina em quadrada. Esta, de excepcional desenho assimétrico, teria sido enterrada por questões de manutenção. Algumas destas alterações já haviam sido empreendidas pelo proprietário, antes mesmo da casa se tornar sede da Fundação ${ }^{117}$. Os procedimentos desta transição acompanham alteração de critérios de significação destes itens arquitetônicos cujas razões poderiam ser associadas ao momento brasileiro do final dos anos 1980, corroborando a ausência de um ethos a permitir que, em 1940-1950, o capital privado reproduzisse o papel do Estado como promotor do movimento moderno em busca de sua representação, episódio comum a outros países latino-americanos como ressaltado em recente revisão historiográfica ${ }^{118}$.

115. No caso latino-americano o conceito de desenvolvimentismo está associado ao processo de industrialização por substituição de importações cf. Pedro Cezar Dutra Fonseca "Desenvolvimentismo: a construção do conceito" in "Presente e futuro do desenvolvimento brasileiro" (IPEA, 2014).

116. Frans Post (1612-1680) pintor holandês em cujos quadros, pintados em sua maioria na Holanda a partir de esboços feitos aqui no Brasil, retratam a paisagem do nordeste brasileiro no século XVII.

117. Conforme constam nas imagens das fotos no acervo da FMLOA.

118.Entre as revisões historiográficas encontram-se as empreendidas pelo grupo Modernidade/Colonialidade, composto majoritariamente por acadêmicos latino-americanos que lecionam em Universidades norte-americanas, canadenses e europeias. 


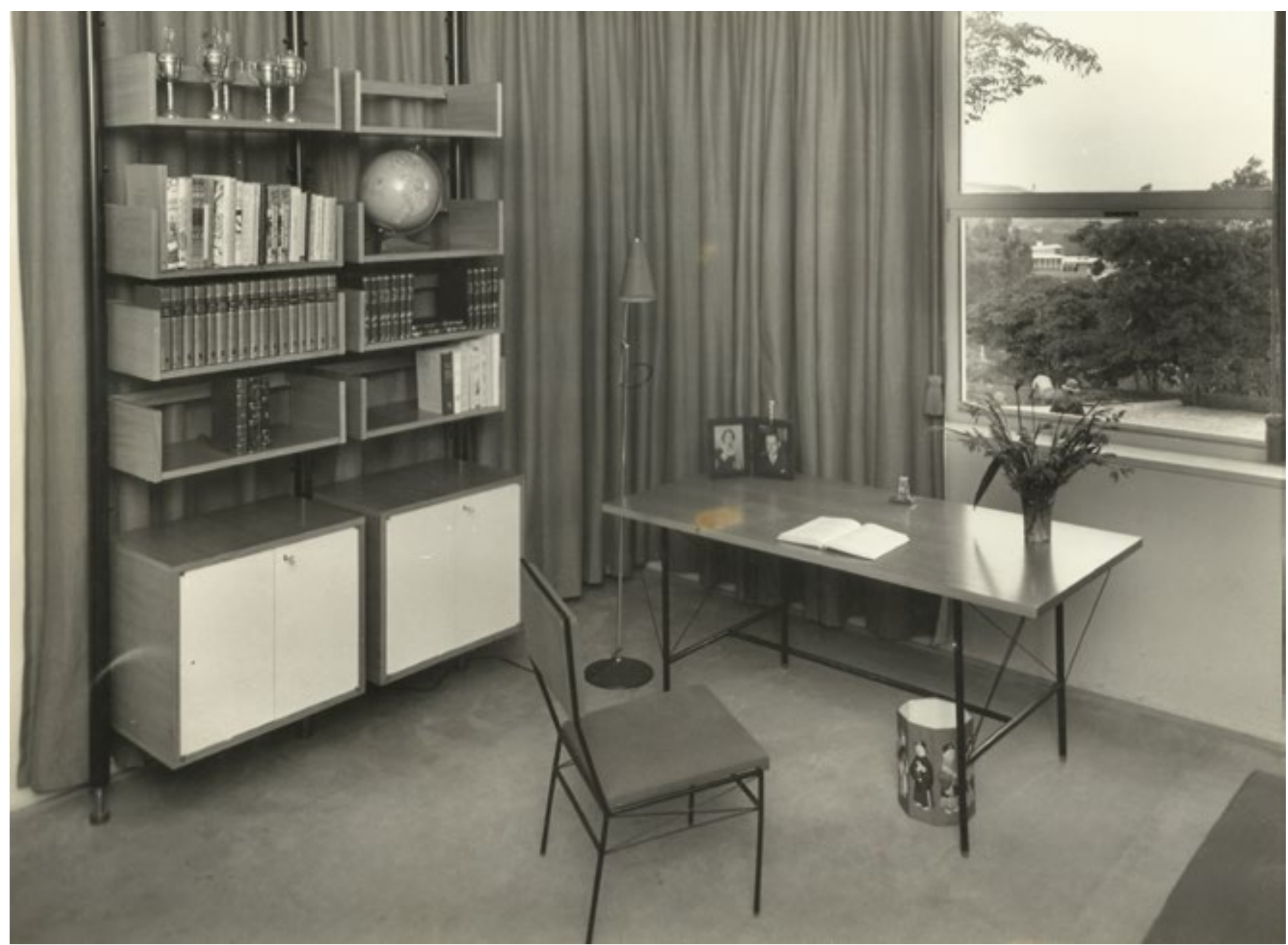

Fig. 29 - Escritório da residência Oscar Americano. Arquiteto Oswaldo Bratke/ interiores: Branco e Preto. 1956. Foto: Peter Scheier. Arquivo da Fundação Maria Luísa e Oscar Americano.

Fig. 30 - Fundação Maria Luísa e Oscar Americano. gabinete do escritório da casa musealizada. 1980. Foto Renato Leary. Arquivo da Fundação Maria Luísa e Oscar Americano.

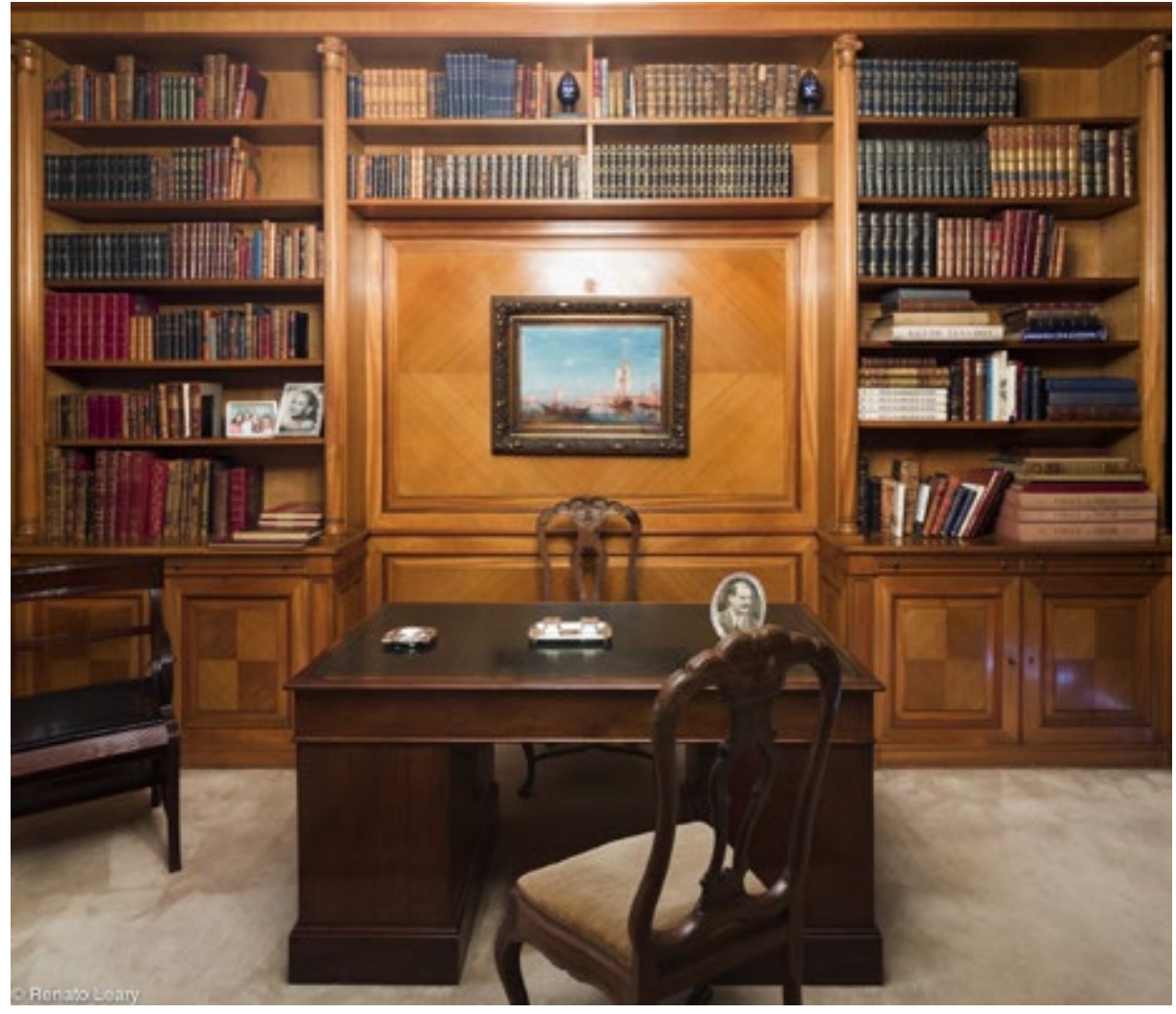


Poderia se considerar o mesmo conceito operativo a elaborar a composição do acervo por meio da aproximação de períodos históricos como motor das interferências promovidas na arquitetura original de Oswaldo Bratke, inserindo materiais e elementos que se pode associar a certa nobreza, mármores, latão, na substituição de outros que remetem à concepção funcionalista e de caráter industrial como pastilhas de porcelana e elementos de serralheria.

\section{Projeto modernista em 1950 - síntese das artes}

A casa e seu pavilhão anexo, idealizados pelo arquiteto Oswaldo Arthur Bratke ${ }^{119}$, construídos em 1951, em terreno com paisagismo de Otávio Augusto Teixeira Mendes ${ }^{120}$, está, desde 1980, aberta à visitação pública. $\bigcirc$ interesse que move o visitante da Fundação parece variar entre os cativados pelo jardim, ou a casa de chá que funciona no pavimento inferior, apreciadores da arquitetura moderna, atraídos pela coleção de arte, motivados ante o conjunto composto por objetos do período Brasil Colônia e Império ${ }^{121}$ e o público que acede à programação cultural de concertos aos finais de semana.

119. Oswaldo Arthur Bratke (1907 - 1997), considerado pela historiografia um dos reconhecidos arquitetos do modernismo brasileiro, projetou, entre outras obras, residências e os núcleos urbanos de Serra do Navio e Amazonas que se tornam referências na busca de soluções tecnológicas e espaciais adequadas a situações específicas. Foi colega de turma de Oscar Americano de Caldas Filho, na Escola de Engenharia Mackenzie, e sócio junto com Eduardo Kneese de Mello em escritório de topografia no final dos anos 1920. Oscar Americano Filho assume cargo no Escritório Técnico Oscar Americano após o falecimento de seu pai, em 1930, abandonando a sociedade com os engenheiro-arquitetos, mantendo, porém, relações estreitas com Bratke durante toda a vida. Bratke constrói importante carreira de arquiteto e urbanista tendo sido o único arquiteto brasileiro a ter uma obra publicada pela revista Arts \& Architecture, em 1948, seu estúdio e residência na rua Avanhandava, no centro de São Paulo.

120. Otávio Augusto Teixeira Mendes (1907 - 1988), engenheiro agrônomo, egresso da Escola de Agronomia Luiz de Queiroz, mestre em paisagismo pela Universidade de Columbia, em Nova Iorque, nos EUA, foi responsável pela concepção do Parque do Ibirapuera, em São Paulo.

121.Segundo pesquisa de público da FMLOA. 

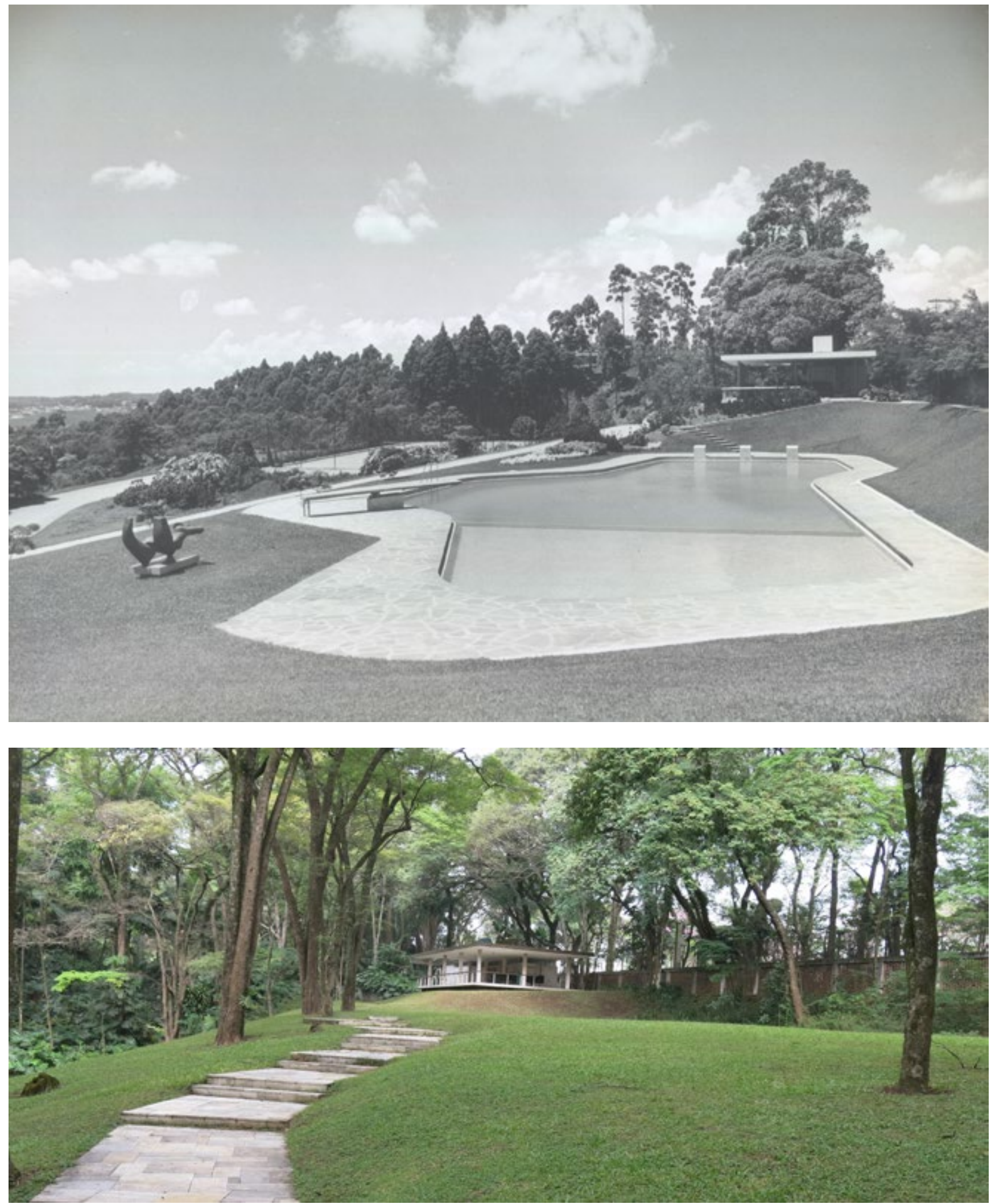

Fig. 31 - Piscina e pavilhão da residência Oscar Americano. Arquiteto Oswaldo Bratke/ paisagista Otávio A.T. Mendes. 1956. Foto: Peter Scheier. Arquivo da Fundação Maria Luísa e Oscar Americano.

Fig 32 - Fundação Maria Luísa e Oscar Americano, pavilhão e piscina soterrada. 2016. Foto Márcia Rossi. 
A materialidade arquitetônica em suas diversas dimensões, a incluir edificações e jardins, exprime neste caso singular temporalidade preterida pelo plano museológico apoiado na ideia da visita à casa de colecionador. Há, porém, inúmeras outras possibilidades de atualização de questões e diálogos com o tempo presente em vários outros setores para além da arquitetura, a citar a museologia, arte, comunicação e tecnologia.

A obra de Oswaldo Bratke obteve grande reconhecimento no meio arquitetônico brasileiro e internacional, em 1951, com a premiação na 1a Bienal de Arquitetura de sua casa no bairro do Morumbi, região da cidade que o arquiteto frequentava e participava na aquisição de áreas junto com Oscar Americano para constituição do futuro bairro Paineiras do Morumbi.

O projeto da casa de Oswaldo Bratke, construída um ano antes da Casa Oscar Americano, com grande rigor formal, por contemplar solução estrutural racionalizada ${ }^{122}$, combinada com inovações e experimentações tecnológicas permitiriam a execução da cobertura plana e de espessura delgada. Hugo Segawa ${ }^{123}$ confere as apropriações formais de Oswaldo Bratke tanto à Residência Farnsworth ${ }^{124}$, às Case-Study Houses, de Richard Neutra, a impressões de sua viagem à Califórnia, em 1947, ou admiração ante à Escola Takeshi Suzuki, afirmando que "É possivel encontrar uma estirpe wrightiana na arquitetura da Califórnia, sobretudo em Richard Neutra, admirador confesso do mestre norte-americano, bem como, indiretamente, identificar as raízes nipônicas na formação de Wright [...]" (2012, p. 51). Segundo Segawa, além de uma das casas brasileiras mais publicadas dos anos 1950, a residência do arquiteto no Morumbi se notabiliza por ter sido visitada por expoentes da arquitetura moderna como Walter Gropius, Marcel Breuer, Alvar Aalto, Kenzo Tange, Siegfried Giedion, Ernesto Rogers, corroborando a tese de que o trânsito de ideias e intelectuais no final dos anos 1940 e início de 1950 estaria ligado à visão da América Latina como espaço de realização do moderno que não se pode concretizar em outras terras, contando para isso com inúmeras "[...] frentes abertas, desde exposições, eventos, cursos, diversificação nas atuações, integração das artes, conquista do espaço urbano liderada pela arquitetura e esforços para implantação de museus." (Lourenço, 1995, p. 225). Entre as iniciativas listadas por Lourenço, o IV Congresso Brasileiro de Arquitetos, em 1954.

122. Helio Herbst Jr. reconhece, com base nas formulações de Giulio Carlo Argan, traços do racionalismo metodológico didático alemão caracterizados pela modulação formal e repetição de elementos padrão na obra de Oswaldo Bratke premiada na Bienal de Arquitetura de 1951. (Herbst, 2007, p. 115).

123. Segawa, 2012.

124. Obra seminal da arquitetura moderna residencial feita no mesmo ano por Mies Van der Rohe em Illinois, EUA, também transformada em casa-museu. 


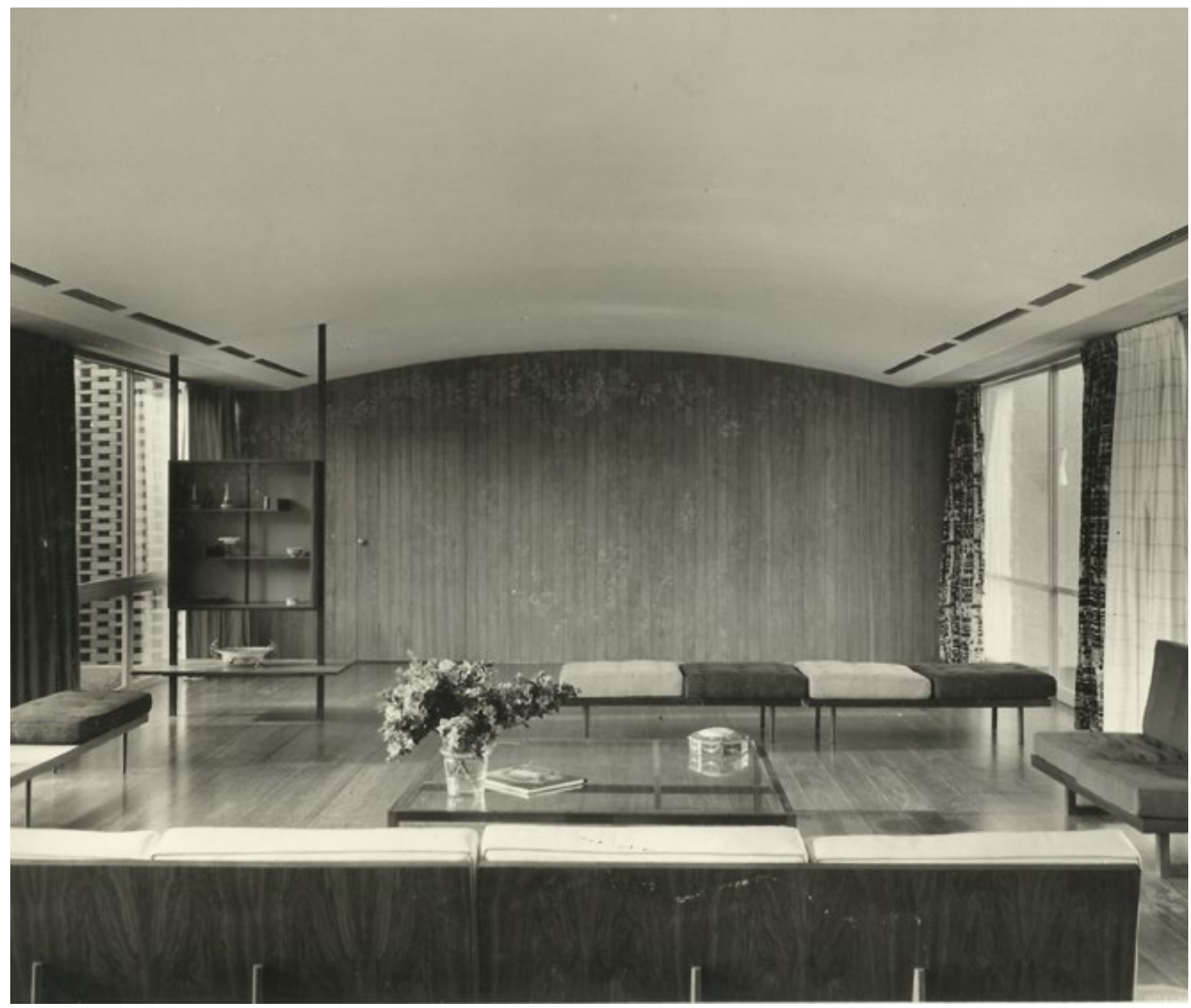

Fig. 33 - Sala de estar da residência Oscar Americano. Arquiteto Oswaldo Bratke/ interiores: Branco e Preto. 1956. Foto: Peter Scheier. Arquivo da Fundação Maria Luísa e Oscar Americano.

Fig. 34 - Fundação Maria Luísa e Oscar Americano, Sala de estar musealizada. 1980. Foto Renato Leary. Arquivo da Fundação Maria Luísa e Oscar Americano

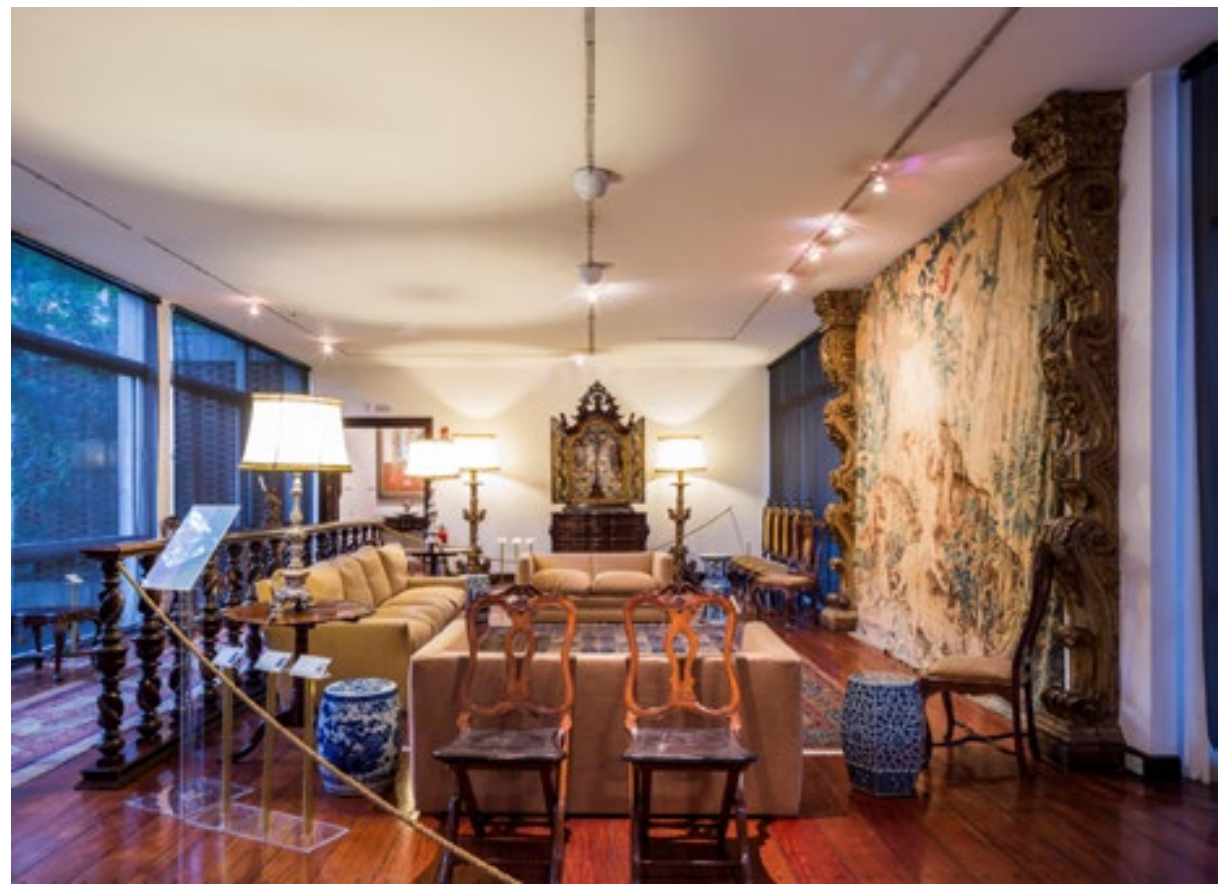


No projeto que Oswaldo Bratke faz para a Casa Oscar Americano, cujas características formais são muito próximas às da sua residência, as qualidades advêm do rigor estrutural combinado com a alternância entre cheios e vazios e soluções tecnológicas inovadoras que estarão a serviço de um extenso programa de casa burguesa. Sua singular solução de implantação e integração ao terreno, na forma de pousar sobre o declive tendo a entrada social com volume térreo e abrindo-se à paisagem com dois pavimentos, apoiada no pátio revestido com a obra de Lívio Abramo125, Foz do rio Amazonas, executada em mosaico português. O espelho d'água com cascata, que dissolve o limite entre exterior e interior fazendo o olhar transfixar-se entre pátio inferior e jardim da entrada, aliado à delicadeza da austera proporção horizontal, propiciada por inovações técnicas, fruto de pesquisas de Bratke, remete ao projeto orgânico wrightiano, solucionando a setorização tripartida ${ }^{126}$ de modo homogeneizado em seu aspecto externo e absolutamente diferenciado, adequado a cada função, internamente. Os planos de vedação nas fachadas exploram a geometria compositiva dos materiais utilizados e efeitos de luz e sombra que produzem compõem visualidade que poderia ser atribuída ao neoconcretismo nas artes plásticas do mesmo período.

\section{Casa-Cidade}

Em ambos os projetos, vale esclarecer, residência do arquiteto e Casa Oscar Americano, é notável a conexão com o momento da cidade que se aproxima de seu IV Centenário, consolidando um caldo cultural que teve seu ápice no desenvolvimentismo dos anos 1950. Desenvolvimentismo do qual Oscar Americano foi protagonista, tendo sua empresa - Construtora Comercial Oscar Americano127 - sido responsável pela execução de obras de engenharia para a expansão urbana da cidade de São Paulo a partir do Plano Avenidas de Prestes Maia, incluindo a malha rodoviária do estado, participando ativamente na construção das rodovias Anchieta, Anhanguera, Castelo Branco.

Momento de extraordinária expansão urbana da cidade de São Paulo, a implantação do bairro do Morumbi torna-se espaço adequado à

125. Lívio Abramo (1903 - 1992), gravador, ilustrador e desenhista, estudou gravura em metal em Paris, em 1951, com prêmio do Salão Nacional de Belas Artes, ganhou, em 1953, prêmio de melhor gravurista nacional na $2^{\underline{a}}$ Bienal Internacional de Arte de São Paulo.

126. Referência às divisões entre área social, íntima e de serviço no programa arquitetônico da residência.

127. Em 1945, o Escritório Técnico Oscar Americano muda sua razão social para Construtora Comercial Oscar Americano, em 1949, para Companhia Brasileira de Pavimentação e Obras (CBPO) e, em 1967, definitivamente, para Companhia Brasileira de Projetos e Obras (CBPO) (Paes, 2008, p. 59). 
materialização de anseios presentes no momento do IV centenário da cidade São Paulo. Conjugam nesta vizinhança, a construção, iniciada em 1954, da sede da Universidade Conde Francisco Matarazzo, projeto de 1938 do arquiteto Marcelo Piacentini, comprada posteriormente em 1963 para transferência da sede do Governo do Estado de São Paulo ao que se chamou então de Palácio dos Bandeirantes ${ }^{128}$, a Capela do Morumbi129, projeto de revitalização empreendido por Gregori Warchavchik, em 1950, a pedido da Companhia Morumby responsável pelo loteamento do bairro, sobre ruínas e taipa de pilão cuja função original é ignorada e as casas de Oswaldo Bratke e a de Lina Bo e Pietro Maria Bardi, construída entre 1950 e 1951. A antiga residência, projetada pela arquiteta hoje sedia o Instituto Lina Bo e P.M. Bardi. Imigrantes italianos com expressivo sucesso e tradicionais famílias paulistanas estabelecem-se no bairro. Fundem-se os objetivos já acionados no movimento constitucionalista, no qual Oscar Americano teve ativa participação ${ }^{130}$, aos da fundação do mito Bandeirante e das comemorações do IV Centenário da cidade de São Paulo ${ }^{131}$.

A relação entre Brasil e EUA ${ }^{132}$, pode ser testemunhada na arquitetura de Oswaldo Bratke, na prosperidade de Oscar Americano e também no projeto paisagístico de Otávio Augusto Teixeira Mendes. Os esforços de aproximação entre EUA e os países latino-americanos estavam em continuidade ao New Deal que poucos anos antes da Segunda Guerra, na chamada Política da Boa Vizinhança, procurava, segundo os economistas que escreveram sobre o período ${ }^{133}$, reconquistar a simpatia dos outros estadunidenses, de modo a tê-los como aliados

128. A partir de 1970 sob o governo Abreu Sodré, iniciou-se a aquisição de obras de arte com o intuito de transformar o Palácio dos Bandeirantes em centro de cultura. A extensa coleção é hoje administrada pelo Acervo Artístico Cultural dos Palácios do Governo do Estado de São Paulo.

129. A propriedade da Capela do Morumbi passou foi transferida à municipalidade em 1975. Revitalizada em 1979, entrou em uso em 1980 como espaço cultural com programação diversificada. Desde 1991 faz parte do Museu da Cidade de São Paulo e abriga primordialmente exposições de arte contemporânea.

130. Oscar Americano alistou-se no Batalhão Piratininga e, logo após a rendição em outubro, assumiu a direção do Escritório Técnico Oscar Americano, após a morte repentina de seu pai.

131. Segundo Maria Cecília França Lourenço, "[...] o 4ํ centenário impulsiona uma série de artistas engajados com o seu tempo, sejam pintores, escultores, bailarinos escultores ou arquitetos" (Lourenço, 1995, p. 236).

132. A empresa de Oscar Americano adquiriu máquinas no final da Segunda Grande Guerra que the possibilitaram atender de maneira única no país à velocidade e qualidade requeridas à implantação das rodovias (Paes, 2008 p. 57).

133. Entre os economistas que escreveram sobre o periodo estão Fernando Henrique Cardoso, Enzo Faleto, Celso Furtado, herdeiros do pensamento conhecido como Tese Prebisch-Singer dos economistas Raúl Prebisch, argentino e Hans Wolfgang Singer, alemão, que versa sobre a deterioração das condições de comércio de produtos primários e bens manufaturados e as diferenças de preço que fazem parte desta troca desigual (Tulchin, 2016, p. 43). 
no conflito bélico que se aproximava. Estas aproximações geram, na cidade, na arquitetura, em instituições culturais, marcas do tempo.134

\section{O jardim}

Os jardins das casas-museu, juntamente com outros elementos materiais e projetuais, constituem elemento fundante para o acervo por possibilitarem a compreensão de certa zona de intermediação entre a arquitetura da residência e a cidade em sua escala mais aproximada, a do bairro e dos habitantes. As restrições edilícias compostas pela regulação concernente às leis municipais contribuem à formação da paisagem urbana e determinam a densidade na ocupação das diversas regiões. Os índices de densidade urbana, diferenciados entre bairro a bairro, inferem identidade paisagística ao espaço da cidade.

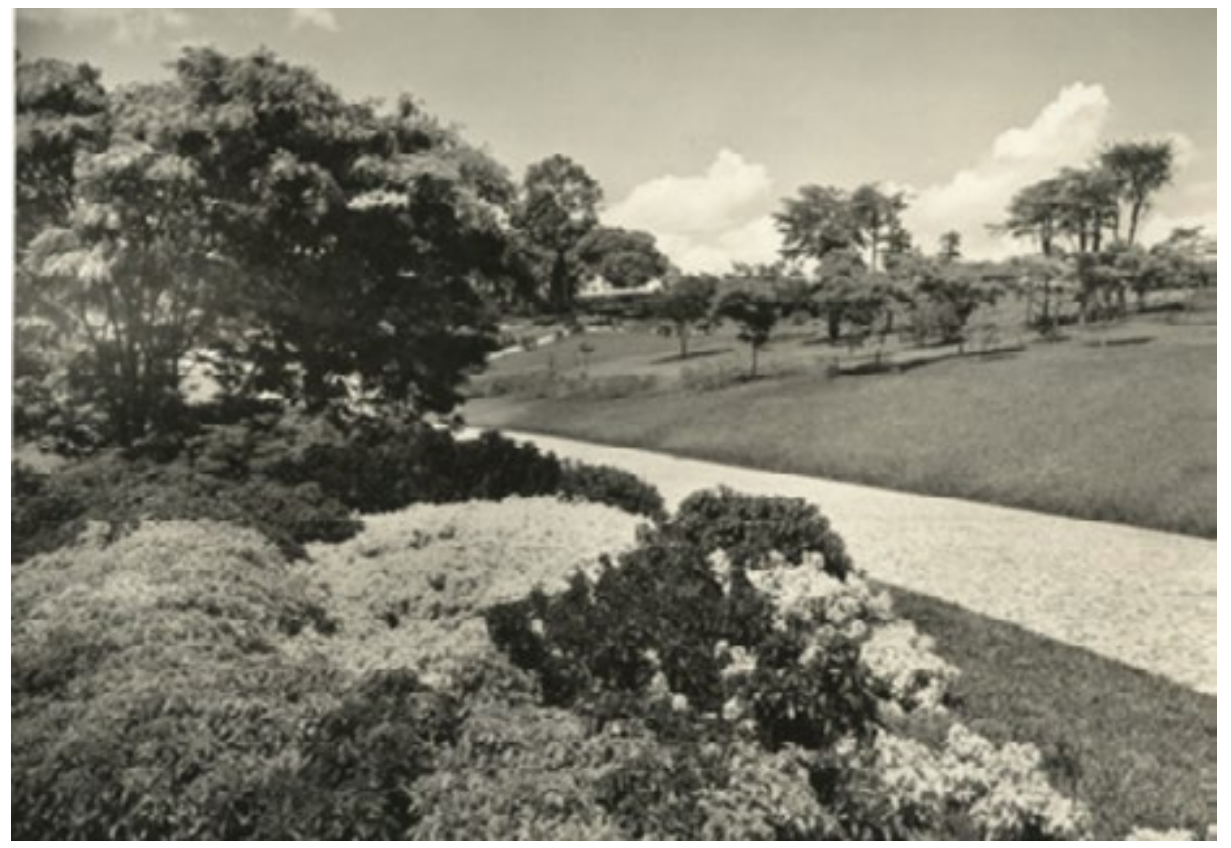

Otávio Augusto Teixeira Mendes, responsável pelo projeto paisagístico da Fundação Maria Luísa e Oscar Americano (FMLOA), foi egresso da Escola Superior de Agronomia Luiz de Queiroz (ESALQ), de Piracicaba, em 1939, e pós-graduado na Universidade de Columbia, em
Fig. 35 - Jardim da residência Oscar Americano. Paisagista: Otávio A. T. Mendes. 1956 Foto: Peter Scheier. Arquivo da Fundação Maria Luísa e Oscar Americano

134. Até o momento da finalização desta pesquisa, novo esforço de aproximação tem sido feito pelo governo federal brasileiro, a partir de 2019, no sentido dos EUA, atestado pelo emblemático acordo de exploração da base militar de Alcântara, MA. Entretanto, dado que a alteração de rumo da política externa brasileira seja bastante recente, os rastros desta ainda não se fizeram perceber nas cidades. 
1950 ${ }^{135}$. Sobrinho de Raymundo Teixeira Mendes ${ }^{136}$, positivista convicto, defensor das doutrinas de Augusto Comte, filho de Octávio Teixeira Mendes ${ }^{137}$, engenheiro da Escola Politécnica da Universidade de São Paulo (USP) e constitucionalista, Otávio replicou, em sua gestão à frente ao Serviço Florestal do Estado de São Paulo as políticas americanas oriundas do New Deal de Roosevelt voltadas à preservação ambiental, determinando medidas de uso e conservação do solo e políticas de criação e gestão de parques. Conjugou sua expertise em agronomia à um dado senso estético ${ }^{138}$, se autointitulando arquiteto-paisagista.

Não foi a primeira e nem a única oportunidade de trabalharem juntos, Otávio e Oscar Americano. São de autoria do agrônomo diversos projetos de identidade e recuperação paisagística nas obras de estradas feitas pela Companhia Brasileira de Pavimentação e Obras (CBPO). Mas sem dúvida, o grande trabalho desta parceria são os jardins da Fundação. Antiga fazenda de chá, a Chácara Clarice, como se chamava era uma extensa área que foi adquirida por Oscar Americano, em 1940. No projeto para o lote de 111.307,70m², Otávio utilizou espécimes nativas paulistas associando conceitos de vida ao ar livre, esportes e recreação ao habitar, alguns entre os preceitos do modernismo

[...] rompendo entraves históricos de desenvolvimento na condição urbana, e para isso revisitando o que sempre caracterizou o país, sua flora e sua paisagem, no período uma faceta do nacionalismo ainda muito pouco explorada. (Mariano, 2005, p. 148)

Otávio instalou um horto no terreno e cuidou deste jardim por mais de dez anos após a sua execução, proporcionando um espaço de identidade arbórea único com a utilização de diversidade de espécies que caracterizam a flora da região do estado de São Paulo. $\bigcirc$ resultado é completamente diferente do jardim também plantado à mesma época por Lina Bo Bardi cuja concepção se funda na recriação de Mata Atlântica, de aspecto bastante próximo ao da mata virgem natural. Dois jardins, dois modernismos.

\footnotetext{
135. Período em que a Universidade era dirigida por Dwight Eisenhower (Mariano, 2005, p. 53). 136. Raymundo é tido como responsável pelo desenho da bandeira nacional, em 1889, em parceria com Miguel Lemos. É atribuida a ele a autoria da inscrição "ordem e progresso" na bandeira nacional brasileira.

137. Cássia Mariano refere que "[...] relatos prenhes de orgulho apontam Octavio, pai, como inventor da matraca, armamento militar utilizado na Revolução Constitucionalista de 1932 [...]" (2005, p. 49).

138. "A paisagem como arte, em tese poderia materializar a musicalidade no espaço" (Mariano, 2005 p. 144)
} 


\section{O mobiliário}

Na casa-museu, os móveis, aqui entendidos como os elementos que não são parte da arquitetura da casa, expressam ao visitante de maneira mais clara, o modo de vida de seus habitantes, o gosto, e as dinâmicas domésticas. Certos exemplares de casas-museu, não dispondo de elementos originais, se baseiam em imagens na busca de reconstruir espaços internos, e procuram reproduzir utilizando frequentemente cópias de modo a reeditar a domesticidade dos espaços.

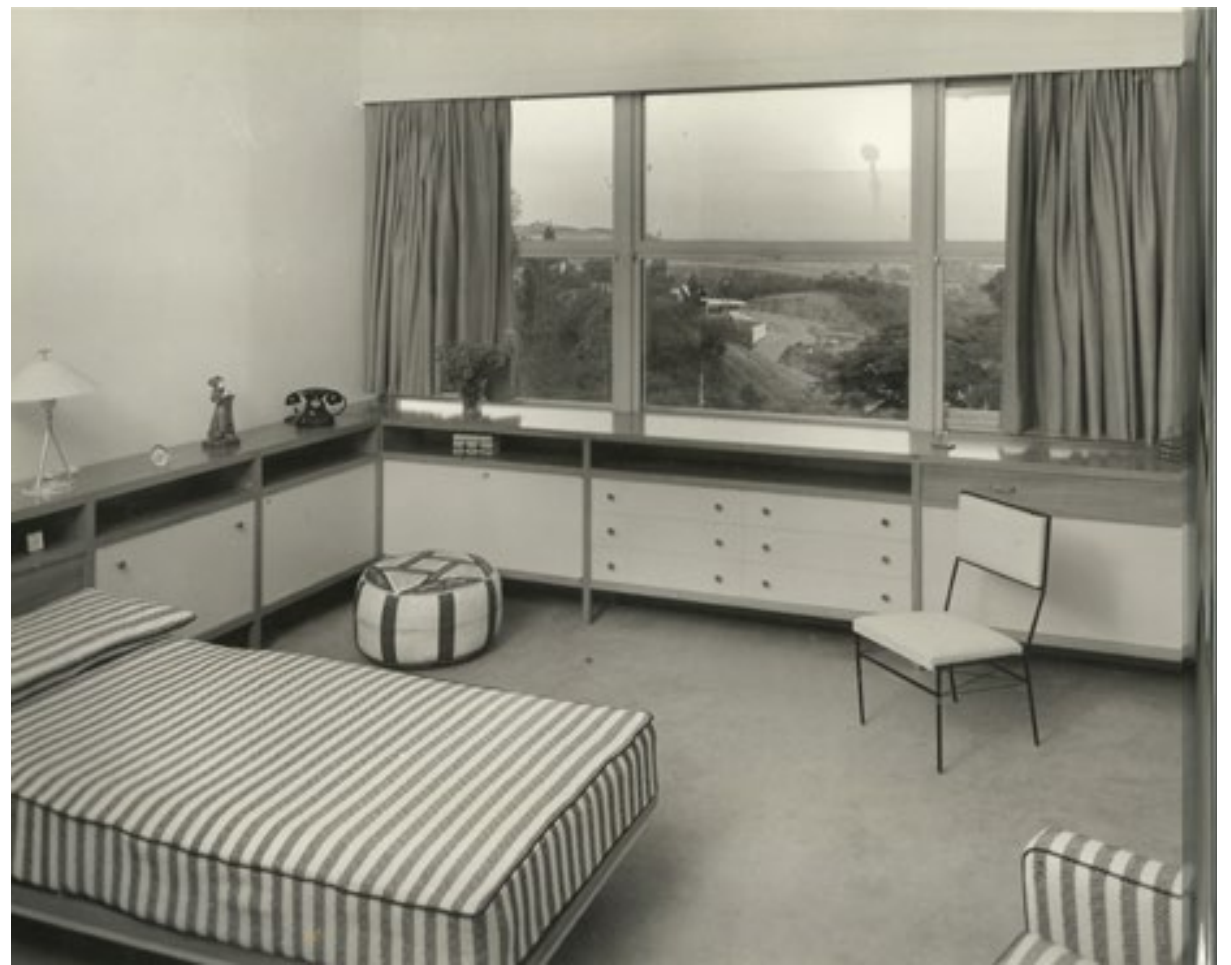

A musealização de residências implica em escolhas relativas à ordenação dos móveis a questionar conceitos de autenticidade e museu ao conferir condições de visitação aos ambientes inicialmente concebidos para a vida privada. No caso em estudo, da Casa Oscar Americano, a decoração da residência foi idealizada e executada, em 1956, pela empresa Branco e Preto ${ }^{139}$, que aliada à oficina carioca de Joaquim Tenreiro, à Unilabor, de Geraldo de Barros, e à Mobília Contemporânea, de Michel Arnoult ${ }^{140}$, envidavam esforços na criação de um mobiliário moderno brasileiro. $\bigcirc$ grupo da empresa Branco e Preto era também formado por egressos da Escola de Engenharia Mackenzie, como Bratke e Americano, e desenvolveram trabalho profundamente identificado com o design produzido nos Estados Unidos, em diálogo com professores
Fig. 36 -

Dormitório de filhos, da residência Oscar Americano. Arquiteto Oswaldo Bratke/ interiores: Branco e Preto. 1956. Foto: Peter Scheier. Arquivo da Fundação Maria Luísa e Oscar Americano.

139. Empresa do ramo de design de mobiliário criada pelos arquitetos Miguel Forte, Jacob Ruchti, Plínio Croce, Roberto Aflalo, Carlos Millan e Chen Y Hwa (Acayaba, 1994).

140. Sobre a Mobília Contemporânea ver Michel Arnoult, design e utopia: móveis em série para todos, organizado por Ethel Leon, editado pelo SESC, em 2017. 
da Bauhaus tornados emigrantes no período entre guerras, fascinados, como disse o Prof. Júlio Katinsky:

[...] pelo entusiasmo comum por Frank Lloyd Wright que advinha não só daquela mesma visão protoluterana do trabalho (tão impregnada na cultura saxônica), como da pregação democrática que o arquiteto americano exprimia em seus escritos. (apud Acayaba, 1994, p. 1)

Certo é que, a partir das exposições do Museu de Arte Moderna de Nova Iorque (MoMA), as obras dos colegas europeus radicados nos Estados Unidos passaram a ecoar para muitos modernos mundo afora. Segundo Acayaba, Jacob Ruchti e Miguel Forte, ambos da Branco e Preto, autores do edifício sede do Instituto dos Arquitetos do Brasil (IAB), em São Paulo, publicado pela Architectural Record, em 1947, empreenderam viagem aos Estados Unidos e conheceram, entre outros, Richard Neutra, Frank Lloyd Wright, Marcel Breuer e Walter Gropius, Alexander Calder, Phillip Johnson. Desta viagem trouxeram peças de Issamu Noguchi, Charles Eames e Eero Saarinen, referências para o empreendimento em direção a um móvel moderno brasileiro. O trabalho na Casa Oscar Americano não se limitou aos móveis apenas, mas também aos tecidos usados nos estofados e cortinas.

\footnotetext{
La modernidad es una tradición polémica y que desaloja a la tradición imperante, cualquiera que ésta sea; pero la desaloja sólo para, un instante después, ceder el sitio a manifestación otra tradición que, a su vez, es otra manifestación momentánea de la actualidad ${ }^{141}$ (Paz, 1994, p. 333)
}

Se tomamos o moderno como na acepção de Octavio Paz, podemos compreender o conjunto estabelecido entre os elementos que compõem esta obra arquitetônica nas tensões estabelecidas entre edifício, jardim e ambientes domésticos. Paz aposta na tradição da ruptura, numa relação entre passado e presente que não é de convivência pacífica, senão de estranhamento. A tradição é o que se repete, neste caso, um desejo de ruptura.

Oswaldo Bratke e Jacob Ruchti eram colegas professores no Instituto de Arte Contemporânea (IAC) e na Escola de Design no Museu de Arte de São Paulo, criada por Lina Bo, que iniciou suas atividades em

141."A modernidade é uma tradição polêmica e que desloca a tradição predominante, seja ela qual for; mas a desloca apenas para, um momento depois, ceder o local a outra manifestação que, por sua vez, é outra manifestação momentânea do presente". PAZ, Octavio. Los Hijos del Limo. La Casa de la Presencia (poesia e historia). Obras Completas (I). $2^{\underline{a}}$ ed. México: Fondo de Cultura Económica, 1994, p. 333. 
março de $1951^{142}$. Segundo Lourenço, o curso era bem estruturado sendo um "[...] projeto ambicioso para a realidade existente" (1995, p. 214) de maneira que compõem as propostas museológicas da instituição recém-criada a considerar a solução dos objetos cotidianos de forma artística, "[...] bastante identificadas com o Museu de Arte Moderna nova-iorquino." (1995, p. 212).

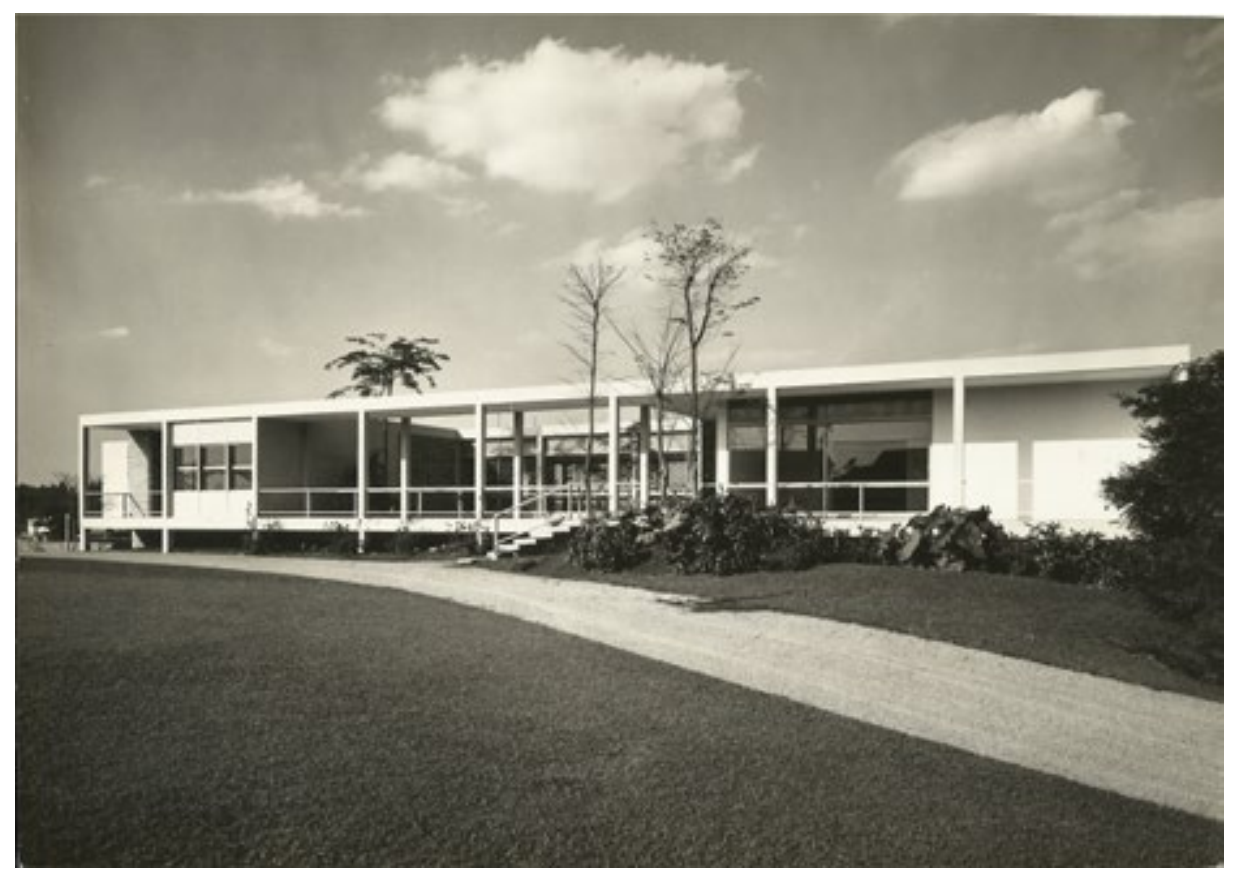

A residência Oscar Americano, trabalho conjunto de Otávio Mendes, Oswaldo Bratke e Branco e Preto, em 1956, nas imagens preservadas pelas fotos de Peter Scheier e Leon Liberman, é documento de uma elegia ao moderno, ao International Style, por obra destes profissionais contundentemente marcados pela arquitetura, urbanismo, paisagismo e design norte-americanos na expansão de uma cidade que, por meio de um desenho urbano inspirado nas cidades jardins explorando a topografia da colina do Morumbi, afirma a ordem social. Realiza o salientado por Angél Rama, relativo às cidades latino-americanas, já que mesmo abandonando o traçado em tabuleiro, instrumento de conceituação da linguagem barroca, novas características tipológicas da estrutura fundiária, com grandes lotes cujas restrições edilícias restringem a ocupação a residências unifamiliares, permitem a continuidade da trasladação da ordem social a uma realidade física:

[...] muito mais importante do que o formato de tabuleiro, que motivou ampla discussão, é o princípio reitor que funciona detrás dela e assegura um regime de transmissões
Fig. 37 - Fachada da residência Oscar Americano. Arquiteto Oswaldo Bratke/ interiores: Branco e Preto. 1956 Foto: Peter Scheier. Arquivo da Fundação Maria Luísa e Oscar Americano

142. Sobre o IAC ver também o livro de Ethel Leon, IAC primeira escola de Design do Brasil, editado pela Blucher, em 2014, a partir de sua dissertação de mestrado, sob orientação do Prof. Júlio Katinsky. 
[...] à construção física da cidade afim de que a distribuição do espaço urbano assegure e conserve a forma social. (2016, p. 26)

Torna-se exemplar a Casa Oscar Americano por conjugar neste episódio de sua criação, de forma privada a "ponte entre modernidade e modernização do país" (Martins, 2010, p. 292), revelando movimento análogo ao apontado por Adrian Gorelik a conjugar Estado e vanguarda na confluência da "[...] necessidade de construir uma cultura, uma sociedade e uma economia nacionais" (2005, p. 16), o momento moderno paulistano incluía a criação do Museu de Arte de São Paulo, em 1947, o Museu de Arte Moderna, em 1948, e a primeira Bienal de Arte, em 1951, com a 1a Exposição Internacional de Arquitetura (EIA). A esta ocasião da cidade de São Paulo correspondeu uma visualidade, composta por unidade formal própria do modernismo tardio, a ressoar um projeto de futuro estadunidense do qual a nascente metrópole teria sido posteriormente alijada segundo autores $^{143}$ que associam fenômenos urbanos das cidades latino-americanas às tensões da relação entre as Américas latina e do norte a partir de uma visada pós-colonial.

\section{A sede da Fundação Maria Luísa e Oscar Americano em São Paulo}

Em 1974, o empresário Oscar Americano criou a fundação144 cujas regulamentações regimentais preconizam a conservação de acervo, prédio e jardim, meses antes de sua morte. Esta atitude, rara entre empresários brasileiros, remete à prática usual nos Estados Unidos, onde incentivos fiscais somam-se a benesses oferecidas pelo papel da filantropia no ideário liberal norte-americano. Durante seis anos, até sua abertura definitiva à visitação pública, em 1980, o imóvel passou por reformas e adaptações para a visitação pública, ocasião em que se decidiu sobre a supressão das áreas de serviço na casa como: cozinha, copa e despensa ${ }^{145}$, e também foram adaptados os espaços destinados à exibição da coleção, ampliada após a morte de Oscar Americano de Caldas Filho. $\bigcirc$ acervo composto por peças do mobiliário português

143. Autores que participam do grupo Modernidade/Colonialidade, entre os quais, Aníbal Quijano, Boaventura Sousa Santos, Santiago Castro-Gomez e Walter Mignolo, estabelecem bases conceituais para as análises de Adrian Gorelik, Jorge Lienur, Luciana Ballestrin, Anahi Ballent, Angela Prysthon, no âmbito da arquitetura e do urbanismo.

144. A Fundação Maria Luísa e Oscar Americano foi constituída em 27/03/1974 no 4응 Cartório de Títulos e Documentos de São Paulo (Livro 1294, Folhas 111, registro no 60.172). Entre os membros do Conselho da Fundação que assinam a escritura de instituição da FMLOA estão, além de Oscar Americano Filho e seus filhos, o colecionador de arte Mário Pimenta Camargo, sua esposa Beatriz e o marchand Renato Magalhães Gouveia.

145. A supressão de ambientes destinados a serviço nas casas-museu é prática corrente nesta tipologia museal. 
e brasileiro datado do período colonial que ambientavam a casa da família na antiga Fazenda do Carmo, em Itaquera, vendida à Prefeitura de São Paulo, em 1975 146 , vem compor os ambientes ao lado da coleção modernista. Esta passa por ampliação substancial de coleções europeias adquiridas em leilões e torna-se importante documentação relativa ao Brasil Colônia e Império ${ }^{147}$. Há clara intenção em promover um encadeamento estético entre estes Brasis: colônia, império e moderno. A sedimentação de uma certa visão colonialista, de matriz europeia, própria das elites paulistas.

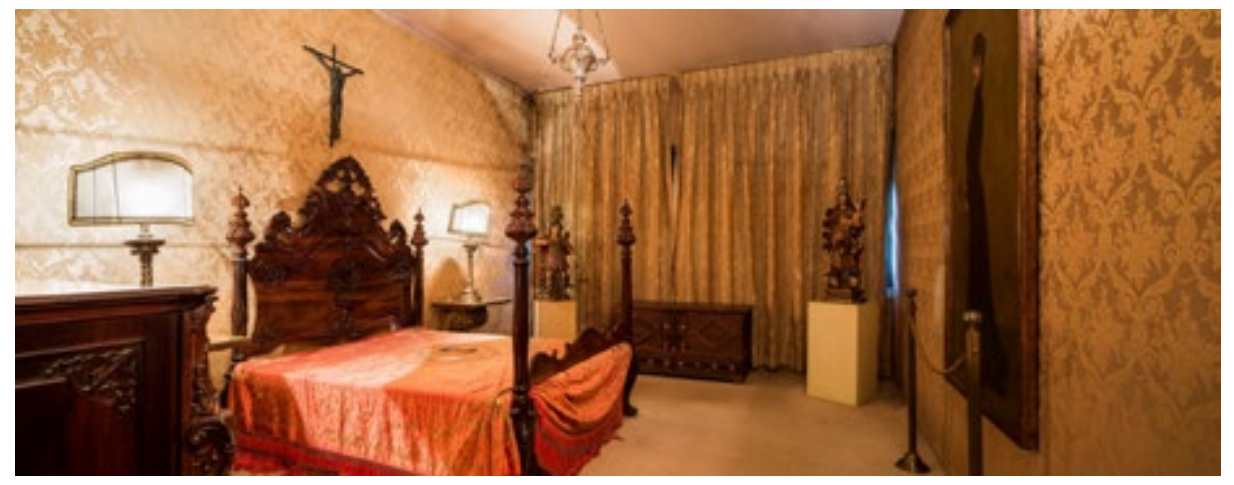

Se, como dito por Néstor Canclini, "[...] são poucos, porém, os estudos sobre as modificações das culturas latino-americanas ao deslocar-se sua relação histórica com a Europa para os Estados Unidos [...]" (2007, p. 69), a trajetória percorrida pela Casa Oscar Americano, de 1951, na direção da casa-museu sede da Fundação Maria Luísa e Oscar Americano, em 1974, poderia colaborar para "[...] identificar em cada caso as equivalências e as rupturas dos diferentes modernismos com as diferentes modernizações da região." (Gorelik, 2005, p. 31), inserindo suas diferenças e complexidades na qualificação de uma casa-museu latino-americana. Neste episódio, compreendida enquanto expressão do movimento moderno, da forma como este ressoou nos países latino-americanos, onde não só o Estado, mas também atores privados a ele vinculados, serviram-se da arquitetura do paisagismo e do design como ferramentas na criação de uma visualidade que os unia ao futuro, à ordem, inferindo sentido diverso do modernismo europeu.

A avaliação de aspectos da trajetória desta residência à casa-museu cumpre o que preconiza Gorelik na

[...] posibilidad de darle una perspectiva urbana a la historia cultural, poniendo em evidencia aquellos episodios de la vida

\footnotetext{
146. A Fazenda vendida parte à Prefeitura e parte à COHAB tornou-se área de expansão de habitação social e o Parque do Carmo, a partir do final dos anos 1970.

147. Paes, 2008
}

Fig. 38 - Fundação Maria Luísa e Oscar Americano, dormitório do casal musealizado. 1980. Foto Renato Leary. Arquivo da Fundação Maria Luísa e Oscar Americano. 
intelectual, artística o cultural en que la ciudad y sus representaciones han intensificado su mutua activación. ${ }^{148}$ (2016, p. 13)

entendendo melhor a casa e a cidade como expressão contemporânea se tomadas "também como campo de tensões" (Castro, 2013, p. 56).

Os museus, internacionalmente, em consonância com as políticas chanceladas pelo International Council of Museums (ICOM), pelo Comitê Internacional para os Museus de Casas Históricas (Demhist) e, no Brasil, em acordo com premissas editadas pelo Instituto Brasileiro de Museus (IBRAM), ocupam-se em debater, pesquisar, formular questões para orientar suas práticas no sentido de atender à crescente diversidade de seus públicos. $\bigcirc$ acesso aos museus, para além do espaço de pesquisa, conservação e divulgação de culturas materiais e imateriais, os torna polissêmicos, espaços apropriados à vivência da dimensão pública contemporânea, sinalizando anseios coletivos e propiciando formas e práticas de pertencimento social em torno destes dispositivos culturais.

Entretanto, nesta pesquisa identifico, na sede da Fundação Maria Luísa e Oscar Americano, uma dissociação entre instituição museal, arquitetura e espaço urbano, em busca de mitificar o acervo composto por espaço, jardim e coleção, à procura de permanências isoladas pelos limites do lote urbano, que significariam certa nostalgia de uma cidade e um urbano que já não existem. $\bigcirc$ diálogo proposto entre a casa-museu e seu entorno é marcado por uma fratura de sociabilidades, na medida em que não reconhece, por exemplo, a vizinha comunidade de Paraisópolis nem ao menos em suas instâncias de rede pública de ensino, focando sua programação e ação cultural numa reiteração de costumes atribuídos a sociabilidades específicas ao lançar mão de práticas anacrônicas contrariando os preceitos estabelecidos pelos órgãos reguladores da atividade museal, contribuindo com uma ficção da dimensão pública contemporânea, recusando anseios coletivos e selecionando públicos em detrimento de sua localização na cidade. mesmo isolamento se instala relativamente às outras instituições culturais do entorno ${ }^{149}$, cuja articulação não se identifica na programação ou na ação cultural até o momento da coleta destes dados. Esta inserção dos equipamentos vizinhos seria um potente instrumento de

148. "[...] possibilidade de dar uma perspectiva urbana à história cultural, destacando os episódios da vida intelectual, artística ou cultural em que a cidade e suas representações intensificaram sua ativação mútua." (tradução nossa).

149. Num raio de distância de um quilômetro e meio encontram-se a Casa de Vidro, sede do Instituto Lina Bo e P. M. Bardi, Capela do Morumbi, Palácio dos Bandeirantes, Casa de Pedra em Paraisópolis, instituições que pautam suas ações de forma isolada, sem atividades que promovam uma articulação entre elas, em benefício da comunidade que as cercam. 
desafio das práticas museais e poderia alterar a significação da sede da Fundação por meio da incorporação de novos públicos, agindo como instrumento de constituição de diversificadas redes, capazes de oferecer alternativas às camadas de interação da população do seu entorno.

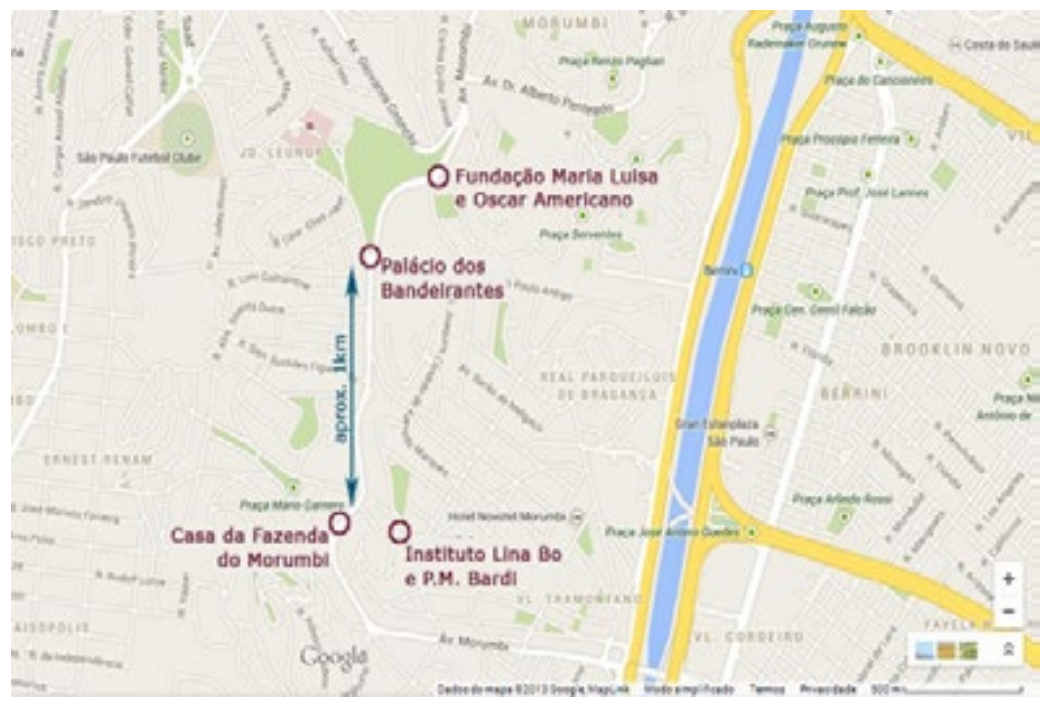

Espaço e tempo se conjugam de formas diversas nestas casas-museus. Seja na sede da Fundação Maria Luísa e Oscar Americano, em que se alternam arquitetura e nacionalismo modernista com saudosismo do período imperial, seja na Casa Guilherme de Almeida, com seu interior estratificado dentro de imóvel de características neocoloniais. Ambas as casas alteraram suas plantas apagando os espaços de serviço dada a irrelevância da arquitetura como acervo, e manipulando o tempo de maneira pouco clara ao receptor, exercendo o chamado poder superior dos museus ${ }^{150}$ à procura de naturalizar procedimentos em função de enredos preestabelecidos de caráter mistificadores, comuns à esta tipologia museal. Não é o mesmo procedimento adotado pela Casa de Vidro, casa-museu em que viveram Lina Bo e Pietro Maria Bardi também no bairro do Morumbi, em que foram mantidos a arquitetura, jardins originais, revestimentos e circuito de visitação que é o mesmo da residência.

Ambas, Casa Guilherme de Almeida e Casa Oscar Americano, atestam, entretanto, a profunda conexão entre fato arquitetônico e cidade que se constroem mutuamente, amparando a hipótese desta pesquisa centrada na ampliação das possibilidades de leitura das casas-museu. Estas, conformariam rede a oferecer conteúdo e produção de conhecimento sobre a cidade, assumindo papel preponderante na significação do espaço para o habitante, fortalecendo o sentimento de pertencimento por meio da compreensão do fenômeno urbano objetivado por práticas museais.
Fig. 39 - Mapa da região do Morumbi, São Paulo, SP. 2020. Desenho do autor sobre arquivo digital. 


\section{CASA}

DE VIDRO/

INSTITUTO

\section{BARDI}

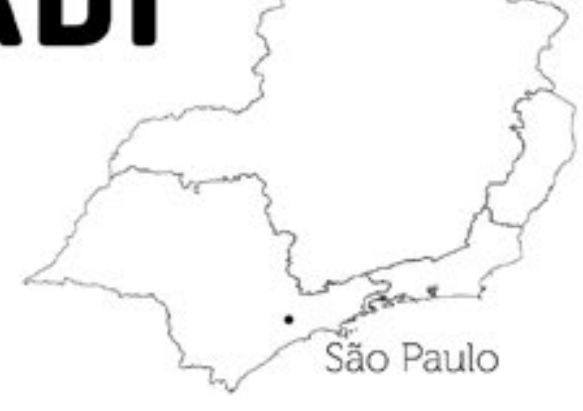

$\begin{array}{ll}\text { Endereço: } & \begin{array}{l}\text { R. Gen. Almério de } \\ \text { Moura, 200 - Morumbi }\end{array} \\ \text { Cidade: } & \text { São Paulo } \\ \text { Arquiteto: } & \text { Lina Bo Bardi } \\ \begin{array}{l}\text { Data de } \\ \text { construção: }\end{array} & 1951 \\ \begin{array}{l}\text { Periodo(s) } \\ \text { de reforma: }\end{array} & \begin{array}{l}\text { Não houve intervenções } \\ \text { Ou reformas. }\end{array} \\ \begin{array}{l}\text { Técnicas } \\ \text { construtivas }\end{array} & \begin{array}{l}\text { estrutura mista metálica } \\ \text { e concreto e alvenaria de } \\ \text { tijolos e vidro }\end{array}\end{array}$

Dados da casa-museu

Inauguração do museu:

1990

Área do terreno: $\quad 4.725 \mathrm{~m}^{2}$

Pavimentos: $\quad T+1$

Área do térreo $\quad 128,67 \mathrm{~m}^{2}$

Área do $1^{\circ}$ pav: $\quad 471,07 \mathrm{~m}^{2}$

Área total:

$599,74 m^{2}$

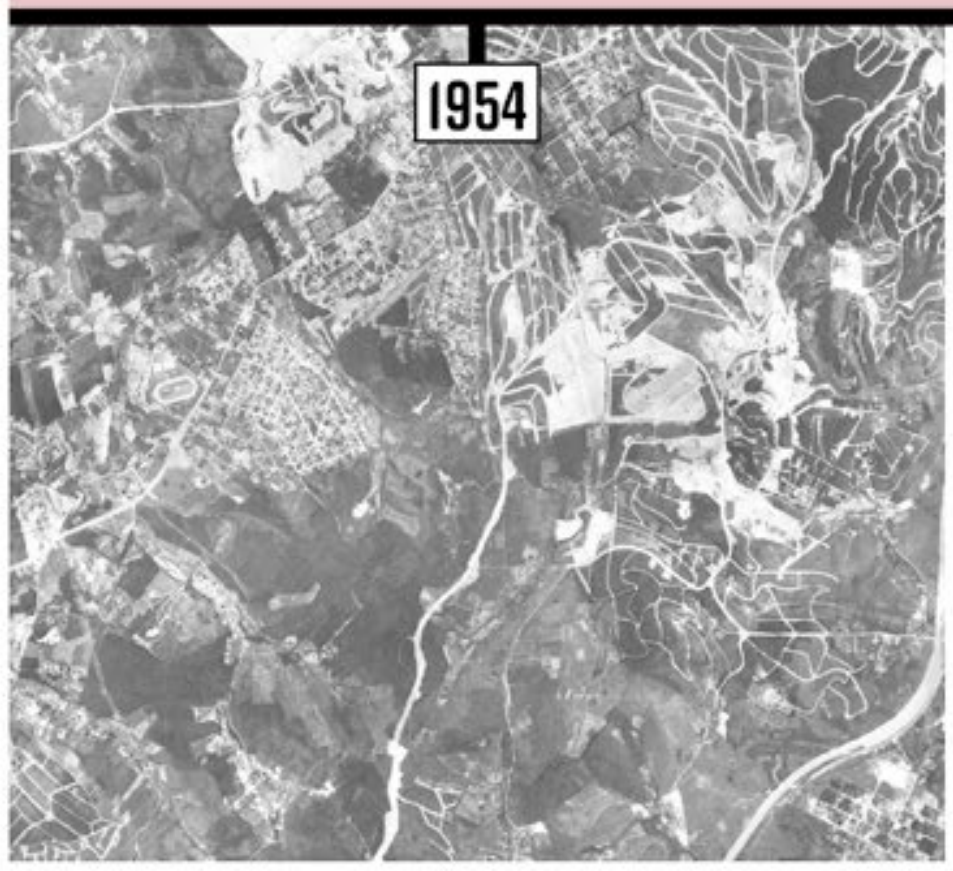




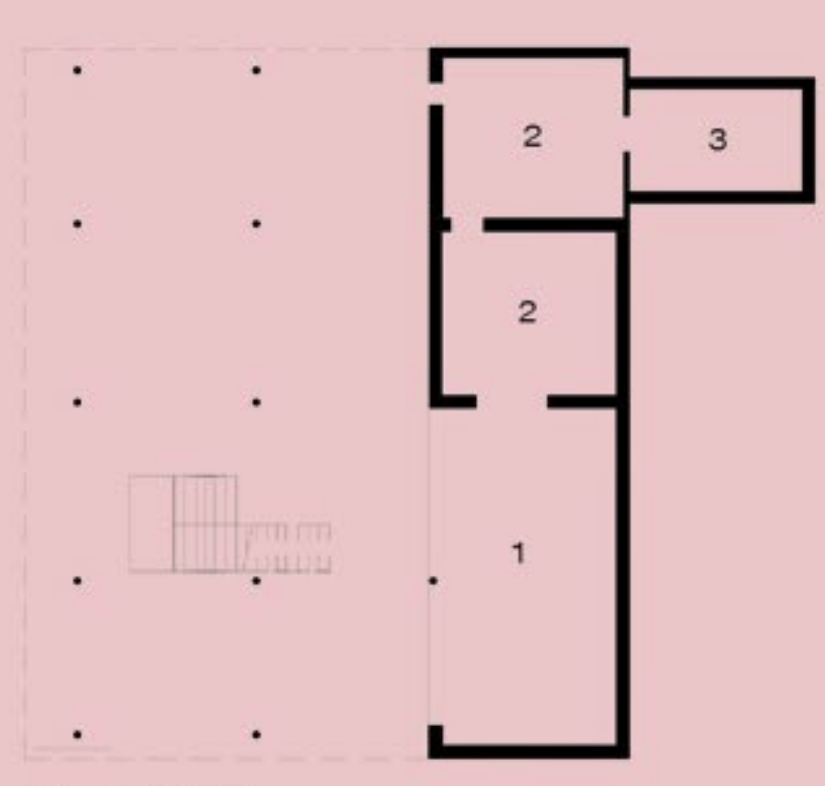

1- GARAGEM

2- DISPENSA

3- SALA DE MAQUINAS

PUNTA PAMMENTo TENCO
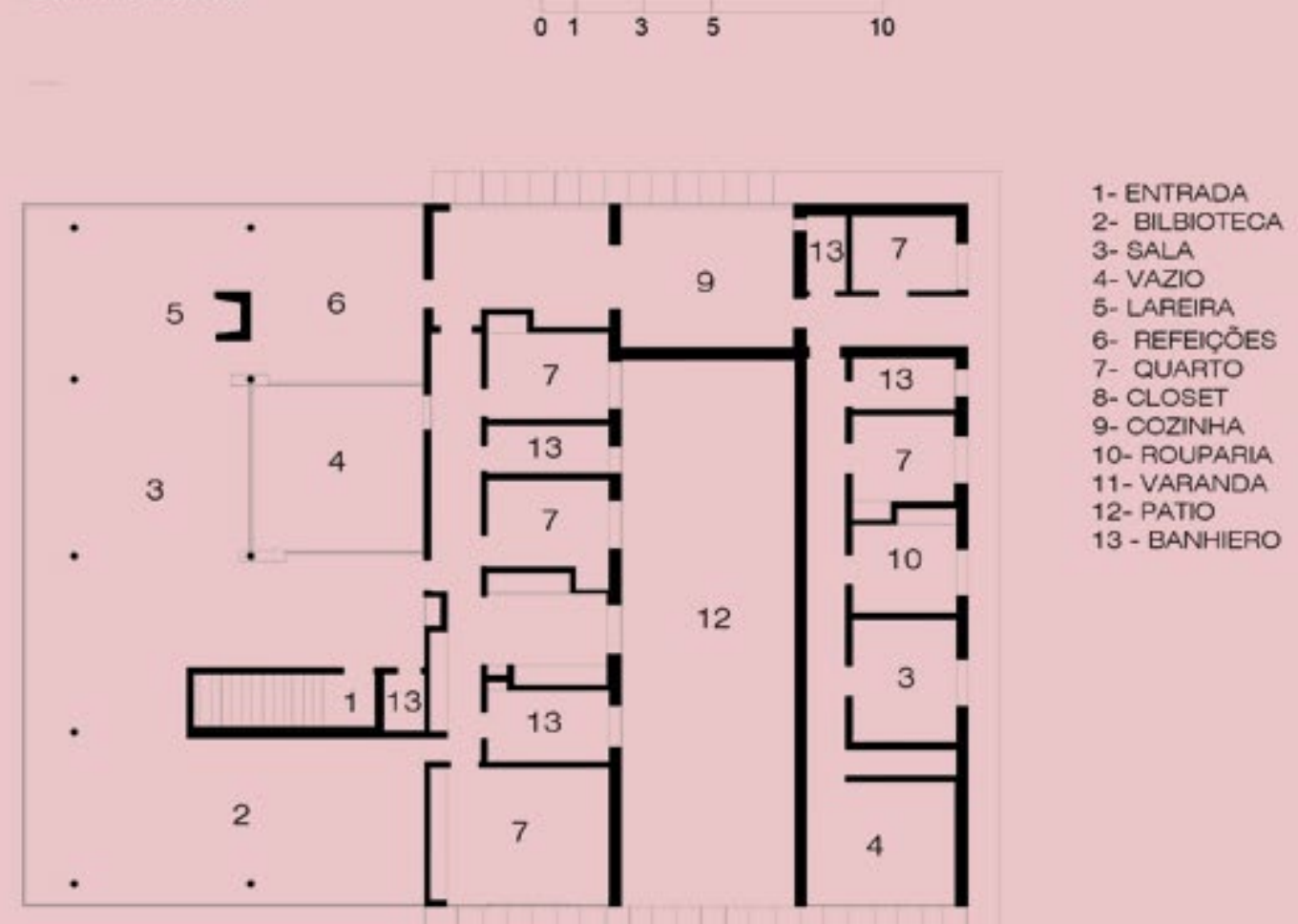

PUNTA PAVEMENTO BUPEAIOR

$\begin{array}{llll}0 & 1 & 3 & 5\end{array}$

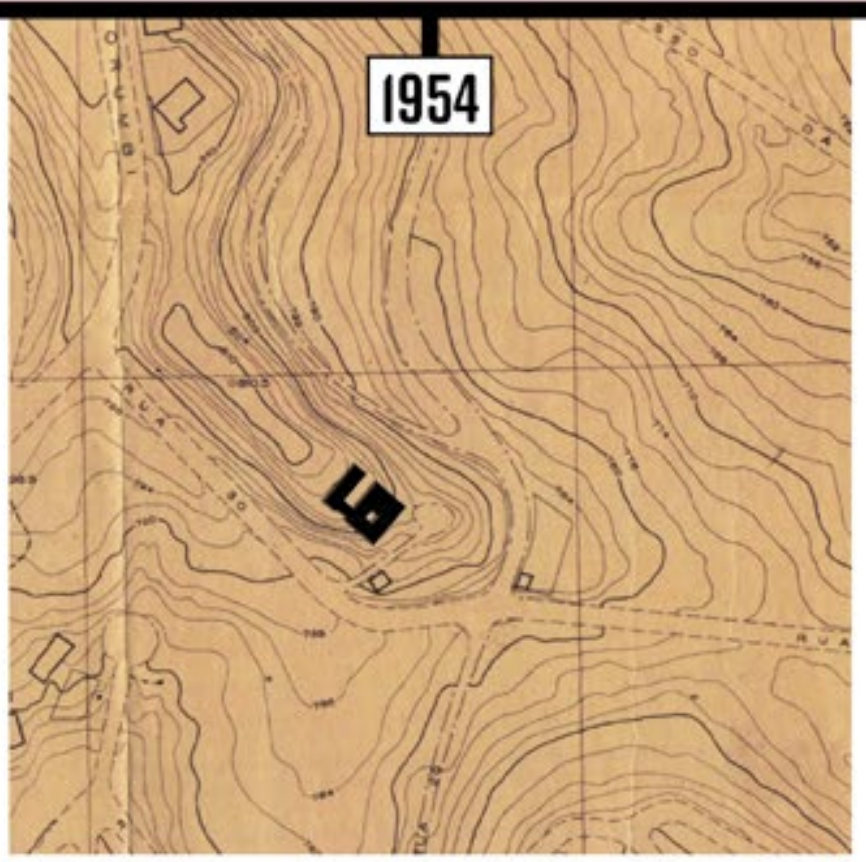

Insersão Urbana

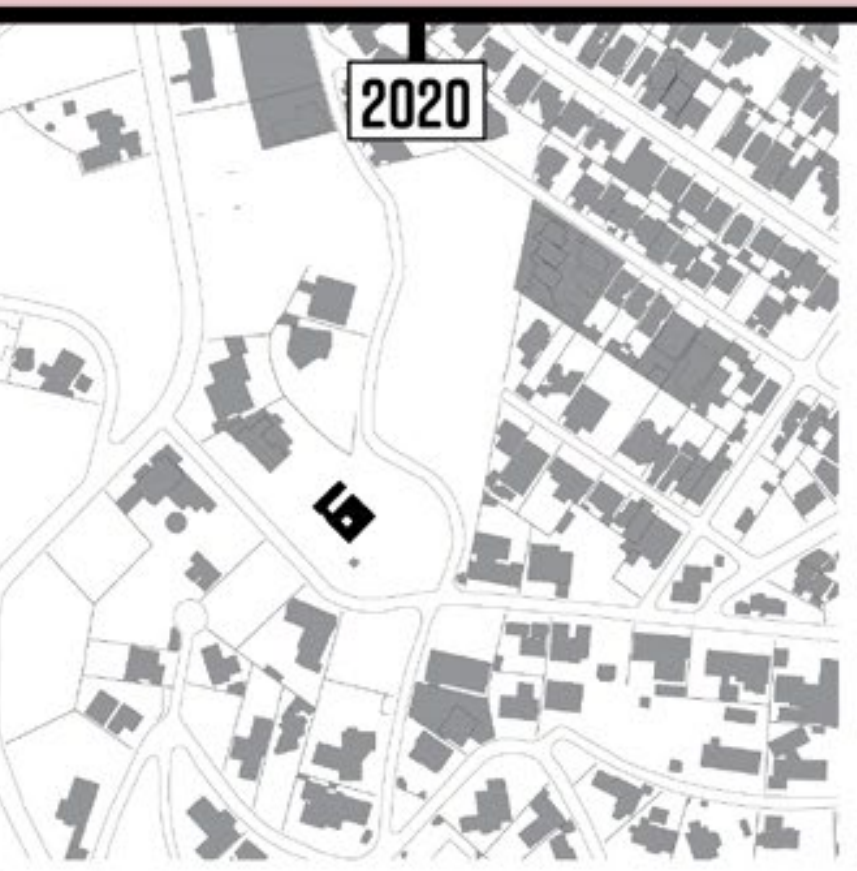

Insersão Urbana 

CAPÍTULO 4

\section{ARTE CONTEMPORÂnEA DA CASA-MUSEU}

A verdadeira matéria do museu é o tempo. (Mia Couto, 2013)

\section{Tempo}

O mote inicial deste trabalho, gestado nas inquietações da prática profissional cotidiana em arquitetura, urbanismo e docência primordialmente, posteriormente aprofundado a partir da pesquisa acadêmica, desde 2010, partiu da investigação das possíveis conexões entre a casa-museu e a disciplina Arquitetura, e tomou a direção, retomando a máxima de Antonio Machado ${ }^{151}$ "o caminho se faz caminhando", da operação do tempo nas casas-museu. Como, por meio de estratégias de musealização e dessemelhanças na construção dos tempos da arquitetura, habitação e construção das cidades, o espaço da casa-museu é agenciado? Em que medida, este mesmo espaço, submetido à presença da obra de arte contemporânea propiciaria fricção entre temporalidades? Na referida fricção residiria um dos meios de ampliação das possibilidades de fruição da experiência capaz de incluir a inalienação da casa, suporte da ação museal, como expressão em múltiplas escalas?

Para que a fricção de temporalidades possa somar-se à vivência do visitante seria preciso a renúncia da casa-museu à simples mitificação que usualmente opera, reconhecendo o implícito poder superior dos museus, consentindo assim a aposta em certa multiplicidade de

\footnotetext{
151.Caminante, son tus huellas

el camino, y nada más;

caminante, no hay camino,

se hace camino al andar.

Al andar se hace camino,

y al volver la vista atrás

se ve la senda que nunca

se ha de volver a pisar

Caminante, no hay camino,

sino estelas en la mar.
}

Antonio Machado (1875-1939) - Proverbios y Cantarse de "Campos de Castilla" XXIX (Fonte:http://www.rinconcastellano.com/biblio/sigloxx_98/amachado_prov.html/) Acessado em 12/01/2020. 
recepções e procedimentos a incluir a Arquitetura e o Urbanismo. Como se tem reiterado a cada capítulo, a pesquisa aqui empreendida procura contribuir ao lançar um olhar à casa-museu atestando que se poderia configurar positivamente uma rede de museus de habitação e modo de vida urbano em diálogo com o extenso conjunto de casas-museu existente, ampliando o foco, usualmente centrado na valorização da personagem homenageada na direção de sua arquitetura enquanto documento.

Embora esta investigação ateste múltiplas condições de transformação de residências em casas-museu, empreendidas ora pela família do homenageado, ora pelo poder público, ora por setores da comunidade, é frequente o recurso desta tipologia de museu ao congelamento do tempo, por meio da recomposição dos ambientes domésticos e pela seleção dos espaços a serem apagados. Os planos museológicos, quando existem, justificam a escolha de um momento, mesmo que ficcional, capaz de corresponder à expectativa imaginada tanto pelos herdeiros quanto por um visitante que iria à casa-museu em busca de confirmar sua compreensão do espaço/ tempo da personagem. Haveria uma alienação da experiência do visitante implícita nesta premissa. A casa-museu se destaca de outras tipologias de instituições museais por oferecer diversas possibilidades de recepção e interpretação que se ativam a partir de elementos materiais e imateriais, dado que alça à condição de coleção uma profusão de itens que, combinados, configuram o universo doméstico. Segundo Giovanni Pina ${ }^{152}$, o que singulariza a casa-museu como instituição é a sua intenção de preservação ou de reconstrução de uma atmosfera real.

Esta ação da seleção temporal, em muitos casos, perpetua estratégias $^{153}$ (De Certeau, 1994, p. 104) para consolidar representações de sistemas sociais anacrônicos afirmados por interiores suntuosos, ou compostos por antigos móveis, objetos e equipamentos, autênticos ou simulados, reduzindo a experiência do visitante à comparação de como foi, como era, propondo uma articulação simplista entre o tempo passado e o presente. Lança mão, desta maneira, de diversas metodologias que se afirmam restritas a esta categoria museal, no intuito de obter um espaço doméstico reconstituído como uma construção temporal. Neste ambiente, interrompe-se, assim, a ação transformadora impressa no tempo e uso cotidiano, as possíveis adaptações ao modo de vida, as modificações impostas ora pela

152. Paleontologista italiano, primeiro presidente do Demhist.

153. Ver nota 17 
inclusão ora pela retirada de algum móvel ou objeto decorativo, os arranjos que atendem necessidades de alterações espaciais pelas mais diversas razões. Ressaltem-se enaltecer qualidades estimadas pela sociedade, apagar desvios, heroicizar a função pública, edição biográfica ou histórica romantizadas, buscando, na materialidade do espaço privado e em sua potência, a asserção de um enredo, para tentar obter a construção de certezas. ${ }^{154}$

Fotografia, filme, pintura, literatura, entre outras artes ou formas de registro, têm sido aliadas importantes na reconstrução destes espaços, quando não determinantes, apontando localização dos móveis, objetos, quadros, em determinados momentos da história destas residências. Na falta de artefato original, autêntico, amiúde recorre-se às cópias justificadas pela demanda de reconfiguração para simular um todo essencial ${ }^{155}$, reafirmando que:

[...] o perigo das instituições monográficas sempre é o culto aos temas, obras e autores, em detrimento do trabalho de serviço à sociedade, além das limitações quanto ao preservado, pela dificuldade de serem incorporados insucessos ou críticas. (Lourenço, 1999, p. 195)

Esta remontagem da casa-museu é planificadora e se orienta por referenciais teóricos cujos vieses evolucionistas e taxonômicos norteiam a organização de objetos em muitos museus desde o século XVIII, e aos quais não caberia encontrar qualquer valor educativo em procedimentos desafiadores à autoridade superior do museu. Não há, como afirma Charles Saummarez Smith, neutralidade no ambiente museal ${ }^{156}$ Para Smith, até os anos 1960, os museus se pensavam como ambientes seguros e neutros aos quais os objetos eram removidos das transações cotidianas que levavam à decadência de sua aparência física,

154. Somem-se a outras razões, casas-museu doadas com condições de endeusar a personagem como excepcional e imortalizada na última versão. Assim, para doadores trata-se de evitar macular memória, como se observa no caso da Casa Kubitschek, Belo Horizonte, MG. Esta permaneceu por décadas em posse de outra família que a revendeu para o Estado de Minas Gerais e recebeu cenarização de época, no afã do projeto de inserção do conjunto da Pampulha, no acervo de Patrimônio Mundial da Organização das Nações Unidas para a Educação, a Ciência e a Cultura (Unesco). O processo de escolha dos sítios e imóveis considerados Patrimônio Mundial pela Unesco é um plano de proteção aos bens culturais do mundo, estabelecido a partir de 1972. Os países propõem a inclusão dos bens na lista por pesquisas que são apresentadas ao Conselho das Nações Unidas. Atualmente são 21 os locais brasileiros incluídos na lista.

155. O Museu Casa de Guimarães Rosa, em Cordisburgo, MG, usa mobiliário coetâneo ao autor que não pertenceu ao escritor no quarto que ocupava. O mesmo acontece na Casa Natal de Charles de Gaulle, em Lille, na França. Ocorre frequentemente a estes imóveis serem musealizados depois de adquiridos por outras famílias e utilizados de diferentes maneiras daquela pretendida pelo enredo da casa-museu.

156. Charles Saumarez Smith, museólogo que dirigiu o Victoria \& Albert Museum, em Londres, questiona a neutralidade atribuída aos procedimentos museais 
supondo que os museus operariam fora da zona em que os objetos mudam de proprietários e de significado epistemológico, o que é falso. Mas sua contribuição fundamental aos conceitos desta tese se dá no entendimento de que os artefatos não existem num espaço próprio, transmitindo significado ao espectador, ao contrário, são suscetíveis a construções de significado que dependem do design, do contexto, dos outros objetos, da arquitetura, urbanismo e paisagismo, da representação histórica e visual e do ambiente como um todo. Transpondo para o fato arquitetônico o que afirma Smith quanto ao significado dos objetos, "mudam não só ao logo do tempo com atribuições diferentes conferidas por instituições ou historiografias, mas a cada dia enquanto pessoas diferentes os veem e os submetem às suas próprias interpretações." (Smith, 2006, p. 19).

A casa-museu, por meio destes procedimentos, oferece resistência a propriedades da atualidade como a instabilidade, a liquidez, a fluidez, a mutação, negando-as como condição de compreensão das questões do tempo presente. Ser contemporâneo, segundo o filósofo italiano Giorgio Agamben, implica a capacidade de se ver, não as luzes, mas as trevas da atualidade, afirmando que:

\footnotetext{
[...] ser contemporâneo é antes de tudo uma questão de coragem: porque significa ser capaz não só de manter fixo o olhar na escuridão da época, mas também de perceber nessa escuridão uma luz que, dirigida até nós, afasta-se infinitamente de nós. (2015, p. 27)
}

Divergindo de museus de arte, históricos e outros, protagonistas da obsessão pela memória desde o final do século XX'157, as casas-museu ainda resistem a inovar linguagens e revisar procedimentos preconizados pela nova museologia, ativa desde os anos 80 do século passado, que sinaliza uma direção da ação museal no sentido de estar sempre "[...] consciente e explorando o relacionamento entre o sistema social e o ambiente físico tridimensional e sempre consciente da etnografia da representação" (Smith, 2006, p. 21). É usual se apresentar ambientes domésticos e jardins restaurados como instrumentos afirmadores de relatos pré-concebidos por enredos biográficos ou históricos, naturalizando temas concernentes ao design, à arquitetura, ao urbanismo e ao paisagismo quando estes são da própria natureza do objeto casa. Possíveis causas desta resistência à transformação de linguagem em casas-museu poderiam ser evidenciadas pela escassez de

157. Andreas Huyssen, diretor do Center for Comparative Literature and Society, da Universidade de Columbia, escreve sobre a obsessão pela memória que tornou o final do século $X X$, período em que proliferaram instituições museais de todo o tipo pelo mundo afora, obedecendo, segundo o autor, a um movimento de reação à compressão do tempo 
pesquisas, expressa pelo número de trabalhos acadêmicos ${ }^{158}$ a elas dedicados, exceção feita às investigações focadas majoritariamente em aspectos da conservação de acervos, já citadas nesta investigação pela Fundação Casa de Rui Barbosa, no Rio de Janeiro, primeira casa-museu brasileira ${ }^{159}$. Certas questões formuladas por Lourenço relativas aos museus de arte moderna tais como "[...] quais são as instâncias responsáveis pela formulação de valores? [...] quais as metas para garantir a continuidade do processo museológico?" (1999, p. 16) seriam aspectos entre muitos outros a serem explorados pelas pesquisas em casas-museu.

Outras pesquisas sobre casas-museu têm sido empreendidas para além de permanências próprias às origens destes museus por membros do comitê específico do ICOM a eles dedicado: o Demeures Historiques - Casas Museos (Demhist), criado no ano de 1988, motivado pela urgência na preservação dos palácios europeus. $\bigcirc$ Demhist tem tido relevante papel no Brasil na promoção de encontros, cursos de formação de pessoal e discutindo questões específicas das casas-museu. Durante anos, o comitê se ocupou de projeto de categorização das casas-museu como instrumento de aprimoramento de práticas.

As questões aqui ressaltadas não estão contempladas no projeto de classificação de casas-museu, disseminada pelo aludido Comitê, conquanto neste âmbito este tenha se ocupado em diferenciar motivos temáticos elencando priorizar o enredo no lugar de interpretar a materialidade encontrada no suporte. Seria então, por um lado, a atração exercida nos diversos públicos e centrada na interpretação de biografias, oferecida pelo compartilhamento de momentos de intimidade e na absorção da ambiência doméstica, e por outro, a contribuição que as denominações prestam à promoção dos intercâmbios, congressos e encontros cada vez mais frequentes em tempos de mundialização da cultura ${ }^{160}$, os motes da referida classificação.

158. Como apontado na introdução, contam-se menos de dez trabalhos acadêmicos nos portais de teses de universidades públicas brasileiras com tema relacionado à casa-museu.

159. Entre outros as pesquisas de Cláudia Barbosa Reis, Regina Monteiro Real e Ana Pessoa são importantes contribuições na área de conservação de casas-museu, envolvendo, inclusive, os jardins como elemento constitutivo da instituição.

160. "A mundialização da cultura redefine o significado da tradição. Temos agora dois entendimentos possíveis de um mesmo conceito. Tradição enquanto permanência do passado distante [...], que aponta para um tipo de estrutura social e [...] representa um mundo anterior à Revolução industrial [onde] a segmentação social, a demográfica e étnica é preponderante, e a presença do campo, das atividades rurais, é marcante. [...] E a tradição da modernidade, enquanto forma de estruturação da vida social [...] que possui uma história. [...] As 'novas' tecnologias - fax, satélites, avião, computadores - contrastam assim com as 'velhas' - telefone, automóveis, máquina de escrever" (Ortiz, 1994, p. 212). 
Tema frequente do referido projeto, o lugar se torna protagonista oferecendo a chance de ressignificação proposta pela fricção com as obras dos artistas concebidas para este espaço especificamente.

As poucas casas-museu que se utilizam da arte contemporânea como instrumento da ativação de seus acervos, raramente consideram a questão da casa e de seu potencial revelador da história da cidade, dos modos de morar. $\bigcirc$ visitante, quando vai à casa-museu, vai à casa de alguém e traz consigo a sua experiência doméstica. Para além de um cotejamento de experiências a ampliação de horizontes de expectativas dos diversos públicos residiria na possibilidade do conhecimento desta casa visitada como documento das escalas doméstica, de vizinhança e do urbano. Traria, nesta nova perspectiva, a experiência da visitação para a subjetivação de materialidade testemunho de processos coletivos, inserindo a dimensão pública em universo privado.

Esta tese contempla a multiplicidade de escalas das quais a casa-museu é testemunha concreta. Localização e inserção na malha urbana evidenciam processos de conformação das cidades, já a relação de vizinhança ao seu entorno imediato estabelece e significa o bairro, enquanto a solução de implantação no terreno, o arranjo interno, a distribuição, percursos, usos dos materiais, móveis, objetos e adornos documentam a citar, entre vários gostos, cultura e arquitetura. A diversidade localizada nas escalas revela, como citado na epígrafe do escritor moçambicano, a matéria prima dos museus: o tempo. Melhor seria dizer: os tempos.

A cidade é composta por conjunto de temporalidades diversas no qual a casa se imprime em determinado momento histórico, também como expressão de técnicas. Ao considerar as técnicas como um conjunto de meios instrumentais e sociais com os quais o homem realiza sua vida, produz e, ao mesmo tempo, cria espaço, Milton Santos "[...] atribui às técnicas o princípio de realidade histórica, relativizando o seu uso, integrando-as num conjunto de vida, retirando-as de sua abstração empírica e lhes atribuindo efetividade histórica" (2017, p. 58).

Trata-se de questionar como a duração, sendo o tempo a principal matéria do museu, tem sido manipulada nesta tipologia museal e que alternativas serviriam a esta operação. $\bigcirc$ tempo do ambiente doméstico recriado transforma seu conteúdo (objetos, móveis, quadros, arranjos espaciais) e seu continente (arquitetura do edifício expressa em seus materiais, escalas, distribuição dos espaços, implantação 
no terreno, orientação, jardins, etc.) em itens de coleção no sentido proposto por Krzysztof Pomian, cumprindo função de semióforo ${ }^{161}$ ao relacionar o visitante, por meio do visível em sua experiência, ao invisível, à ideia, ao enredo.

A operação de montagem na casa-museu instaura, desta forma, um modo de visualização do passado congelando um momento da dinâmica espacial doméstica. Entretanto, é sempre no presente que se dá a experiência do receptor conforme descrita por Hans Robert Jauss em sua Estética da Recepção, concebida ao final dos anos 1960, articulando conceitos como "horizonte de expectativas" e "distância estética", dada a importância neste objeto de estudo reitere-se o que antes se explanou, instituindo ferramentas metodológicas a possibilitar uma avaliação da obra de arte que desloca o eixo de análise, focado anteriormente em obra e autor para a sua recepção, permitindo observar que a perspectiva futura aquiescida por repertório pretérito, vistas por Jauss como construções sociais, instrumenta a indagação do visitante do museu ao passado, como uma chave à compreensão do tempo presente.

Objetos domésticos, móveis e quadros de uma casa-museu, dispostos ao olhar do observador e do curador atribuem sentido na unidade e no conjunto. Quando esta operação é vista à luz da Estética da Recepção, valeria dizer que os procedimentos inferidos aos elementos da casa-museu desafiariam o horizonte de expectativas do receptor, ampliando sua experiência de maneira crítica. Jauss vê a recepção como tensão entre tempo presente e tempo histórico. Caberia, entretanto, inquirir como se daria esta operação entre receptor e objeto ou conjunto de objetos, para qualificar a individuação daquilo que a recepção descreve no âmbito social.

Ao analisar as obras dos artistas minimalistas norte-americanos da década de 1960 em seus esforços para a criação de "[...] um objeto que não inventasse nem tempo nem espaço além dele mesmo", Georges Didi-Huberman (2010, p. 53) parte, entre outros, do conceito de aura de Walter Benjamin quanto à modalidade do visível. Qualifica a operação de substituição envolvida na tautologia, invocada como a recusa da aura do objeto e na crença, ou invisível previsto, categoria próxima do semióforo de Krzysztof Pomian, que tece profunda análise do conceito de coleção com base em suas origens remontadas ao neolítico, passando pela significação atribuída aos objetos sagrados.

161.Semióforo, na concepção de Krzysztof Pomian, é o objeto cuja capacidade intrínseca é, a partir do visível, ligar o homem ao invisível, ao que não está lá (1984). 
Assim, ao se considerar que a percepção do espaço e objeto doméstico pelo visitante da casa-museu estaria condicionada às diversas esferas de significação, expostas por Didi-Huberman, entre a coisidade do objeto em si e suas potencialidades de significação, a recepção se vê mediada por uma tentativa recorrente de cenarização do ambiente. Uma estratégia que reduziria as possibilidades de compreensão do objeto e seu conjunto, privados da proficuidade a eles atribuída pelos diversos olhares a que se expõem. Pois, segundo o autor:

\section{[...] ver é sempre uma operação de sujeito, portanto uma opera- ção fendida, inquieta, agitada, aberta [...] e não há que escolher entre o que vemos e o que nos olha. Há apenas que se inquietar com o entre. (2010, p. 77)}

A experiência da arquitetura, o espaço praticado de De Certeau, evidencia a espacialidade precípua da casa que se oferece à investigação sobre modos de operação do presente sobre este dispositivo espacial162, a instaurar diferentes temporalidades, apoiadas em outras linguagens como a literatura e o cinema.

À Teoria Estética da Recepção, sucede-se como aporte teórico, a ideia de representação proposta pelo historiador Roger Chartier, que, ao analisar a história do livro, procura ampliar a compreensão da construção dos sentidos, historicizada por Jauss, ao incluir no processo o suporte material. Dessa mesma maneira, proponho ampliar as possibilidades de interpretação da casa-museu ao considerá-la desde sua materialidade, como proposto por Chartier ao afirmar, em relação à obra literária, que

Contra a representação, elaborada pela própria literatura, segundo a qual o texto existe em si, separado de toda materialidade, é preciso lembrar que não há texto fora do suporte que Ihe permite ser lido (ou ouvido) e que não há compreensão de um escrito, qualquer que seja, que não dependa das formas pelas quais atinge o leitor. (1991, p. 11)

A representação, como colocada por Chartier, tem duplo sentido, aparentemente contraditório, sendo o primeiro de visibilidade de uma ausência, em que há distinção clara entre representante e representado; e, o segundo, de apresentação de uma presença, em que "uma relação decifrável é portanto postulada entre o signo visível e o referente significado - o que não quer dizer, é claro, que é necessariamente decifrado tal qual deveria ser." (1991, p. 13).

162. Na expressão de Monique Eleb, autora francesa que estuda a transformação do espaço doméstico à luz da história das mentalidades, e que ministrou palestra no Simpósio Domesticidade, gênero e cultura material organizado pelo CPC-USP, em maio de 2014. 
Roger Chartier, ao tratar das práticas e representações, afirma que, a perspectiva de uma história cultural diferente se dá contra uma redução da interpretação que estabelece correlações simplistas entre niveis e indicadores sociais, incluídos aqui os testemunhos materiais a estes associados, se desconsideradas as alterações resultantes de práticas e apropriações ao longo do tempo. Sua acepção da representação contribui nesta pesquisa com a compreensão que confere à forma na construção do sentido. Em sua pesquisa dedicada à história do livro, Chartier defende a relevância da materialidade na significação da obra. Somada à compreensão que Jauss tem do receptor como sujeito da experiência a partir de um repertório simbólico pregresso, para Chartier, forma, condições de produção e de distribuição da mensagem, inferem a recepção. O que leva a dizer: não há casa sem cidade e nem o oposto.

Novos usos culturais têm sido sugeridos a outras casas, conformando nestes espaços lugares de práticas artísticas plurais em que a arquitetura propicia a vivência da proficuidade das artes em contraposição à casa-museu, em que o uso da espacialidade quase sempre concorre à valorização de uma personagem.

Observo que a presença da arte contemporânea na casa-museu torna visíveis sistemas de representação ali instalados contribuindo à percepção do espaço vivenciado, em temporalidade atual e não apenas com nostálgico rever do passado. Experiências nessa conjunção entre casa-museu, espaço e arte contemporânea vislumbram a eficácia da citada conexão por precarizar aquilo que toca, e pela capacidade de reordenar os elementos da casa-museu, cenário da vida doméstica, germinando novas semânticas fundadas na arte contemporânea, a partir dos mesmos signos.

A arte posterior ao moderno vem dialogando de forma sensível com as diversas condições operadas em dado lugar. Estudiosa da ativação do lugar por meio da arte contemporânea, Miwon Kwon ${ }^{163}$ afirma que os artistas da chamada arte site-specific, desde o final dos anos 1960 e início de 1970, procuraram incorporar as condições físicas de um lugar particular como integrante da produção, apresentação e recepção da arte, até atingir um ponto de exaustão político e estético a promover um esgarçamento do termo, aplicado de forma indiscriminada à obras de arte, exposições em museus, projetos públicos, passando a significante automático de certa criticalidade ou progressividade pelo sistema da arte, corroborando a tese de apropriação e

163. Miwon Kwon (1961) é curadora e professora de História da Arte na UCLA Universidade da Califórnia, Los Angeles, EUA. 
domesticação das práticas artísticas de vanguarda pelo mercado. Em resposta, segundo Kwon, muitos artistas, críticos, historiadores e curadores ofereceram formulações alternativas assinalando uma tentativa de forjar possibilidades mais complexas e fluidas das relações entre arte e lugar desestabilizando este último conceito até os anos 2000.

Desta maneira, a arte site specific, como concebida por autoras como Kwon e Rosalyn Deutsche, estabelece-se à maneira de um discurso estético-urbano ou cultural-espacial combinando ideias sobre arte, arquitetura, e design com teorias da cidade, espaço social e espaço público, contemplando obras focadas no lugar e que deslocam este termo na direção de sentidos que potencializam a casa-museu por meio da fricção de temporalidades problematizando a casa, a domesticidade, o urbano e a cidade.

\section{Camondo e Soane}

Como maneira de pensar outras perspectivas da ação do tempo sobre a instituição museal e sua missão, essa pesquisa incluiu entre as instituições visitadas o estudo do Museu Nissim de Camondo ${ }^{164}$, referência entre as casas-museu francesas pela qualidade de seu acervo. Concebido originalmente por seu proprietário, Moïse de Camondo, e deixado em testamento coleção e edifício ao Museu de Artes Decorativas da França ${ }^{165}$. $\bigcirc$ museu foi nomeado em homenagem a seu filho, tenente da aeronáutica francesa morto prematuramente, em 1917, que tinha o mesmo nome do avô, banqueiro de origem sefardita na Turquia. A coleção compreende mobiliário, tapeçaria, objetos e obras de arte do século XVIII, reunidos durante sua vida, compondo um cenário de alta cultura e laico para inseri-lo na abastada vizinhança de moradores do loteamento no entorno do Parque Monceau, e na alta sociedade parisiense do final do século XIX166, dissimulando oportunamente sua origem judaica.

\footnotetext{
164. A visita técnica ao Museu Nissim de Camondo ocorreu em 30/12/2013. Fui recebido pela conservadora Sylvie Legrand-Rossi que discorreu sobre as novas áreas que o museu abriu à visitação.

165. Moïse de Camondo é um dos fundadores o Museu de Artes Decorativas da França.

166. O edifício do museu foi construído por ele, em 1870.
} 


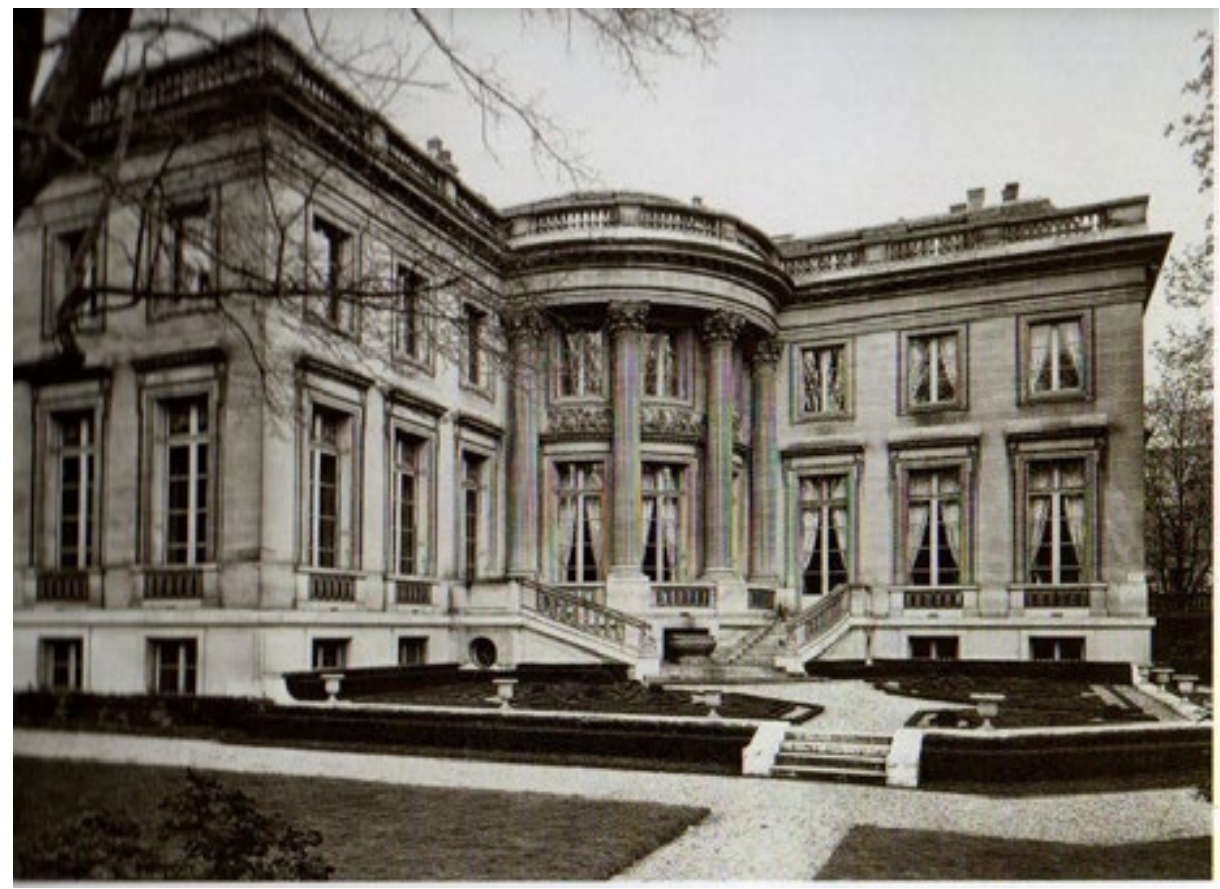

Não há nenhuma referência à origem de sua família na decoração do imóvel, exceto a indumentária seus pais em duas fotos de pequenas dimensões. Os ambientes sociais da casa foram totalmente preservados com base nas fotos feitas por encomenda de Moïse e as recomendações quanto à fidelidade da exposição do acervo constam de seu testamento. A fotografia é comumente utilizada como fonte na reconstituição dos ambientes das casas-museu, por permitir "[...] a apreensão e compreensão de diferentes tempos, em diferentes leituras ou camadas interpretativas [... ]".(Rizolli, 2017, p. 21)

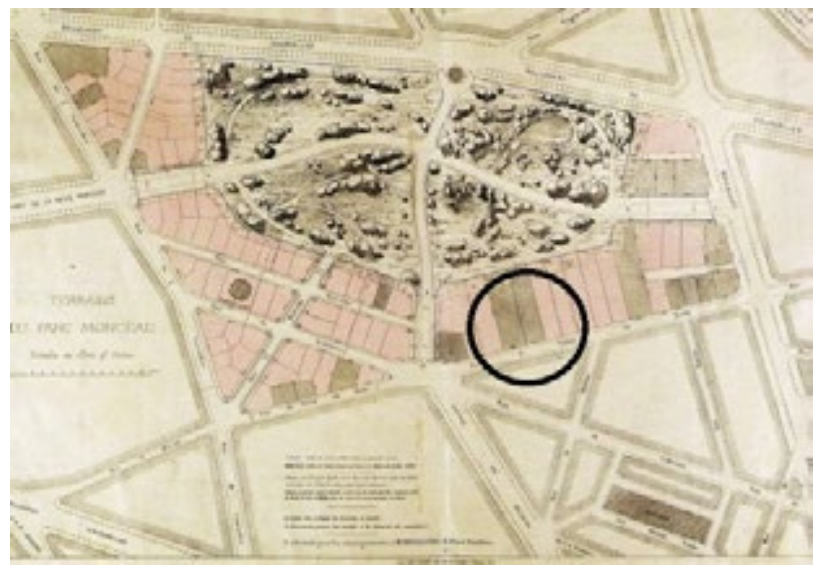

Recentemente, a partir dos anos 2010, as áreas destinadas aos serviços da residência, que não constavam da determinação original do colecionador, passaram por restauro para serem exibidas ao público, em face da demanda representada pelo interesse nos modos de vida usados no passado, confiando à cozinha da residência, aos apartamentos dos empregados, áreas de despensa e
Fig. 40 - Museé Nissim de Camondo, Paris, França. Fachada. 2016. (Museé Nissim de Camondo, 2007, p.72)

Fig. 41 - Mapa do loteamento do Parc Monceau em Paris. 2018. Desenho do autor sobre imagem digital de arquivo do Museé Nissim de Camondo. Fonte: (Museé Nissim de Camondo, 2007, p. 58) 
Fig. 42 - Planta do vestíbulo da residência Moïse de Camondo. Arquiteto René Sergent. Fonte: (Museé Nissim de Camondo, 2007, p. 79)

cavalariças a categoria de ambientes mais visitados do museu e expondo também desenhos criados para o projeto de arquitetura do imóvel com autoria de René Sergent ${ }^{167}$.

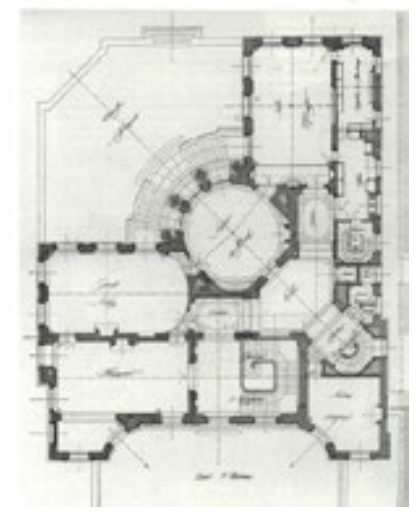

○ Museu Nissim de Camondo, em Paris, mantém a estratégia de fiel reconstrução do ambiente doméstico, que, entretanto, não recompõe o tempo de sua real vivência. A família habitou a casa desde o final do século XIX, projetada segundo preceitos arquitetônicos setecentistas e decorada por uma coleção de móveis, objetos, tapeçarias e quadros do século XVIII. É o viés do colecionismo que norteia plano museológico e ação deste museu. Entretanto, a valorização de ambientes anteriormente não visitáveis nesta casa-museu exemplifica bem o processo de deslocamento da missão institucional em relação aos postulados originais, neste caso, determinados em testamento. Há um realinhamento da casa-museu ao horizonte de expectativas do público visitante, que abre muitas outras perspectivas de ação museal. $\bigcirc$ museu Nissim de Camondo segue ampliando seus públicos e procedimentos, focando a sua ação nas possibilidades de interpretação abertas pela materialidade de seu acervo ao longo do tempo, na condição de testemunhar modos de vida, costumes e rede de relações de produção do passado sem abrir mão dos estatutos firmados por seu patrono.

Em setembro de 2011, pela primeira vez, o Museu Nissim de Camondo cedeu espaço a uma exposição de arte contemporânea em seu espaço intitulada Échos, concebida em convênio com o curso de mestrado em curadoria da Universidade Sorbonne (Paris IV)168. A proposta de curadoria feita pelos estudantes do curso instalou obras de artistas

167. René Sergent (1865 - 1927), arquiteto francês formado em Paris e autor de várias obras em seu país, Bélgica e Argentina. Em Buenos Aires, criou a residência Errázuriz-Alvea, em 1911, hoje sede do Museu de Artes Decorativas na capital argentina. Disponivel em $<$ https://www.mnad.org/index.php?subP=residencia/>. Acesso em: 12/02/2018.

168. A exposição Échos ficou em cartaz entre 14 de setembro de 9 de outubro de 2011 com obras de artistas da cena contemporânea, como Louise Bourgeois, Felix González-Torres, Maria Loboda, entre outros. Disponivel em: <www.lesartsdecoratifs.fr>. Acesso em: 15 out. 2018 . 
contemporâneos dentro do espaço do museu procurando introduzir um diálogo com a história do lugar e oferecendo, de acordo com o texto dos curadores, uma nova oportunidade de apreensão da experiência no museu na confrontação dos tempos ali expressos.

O Sir John Soane's Museum ${ }^{169}$, em Londres, no Reino Unido, considerado a mais antiga ${ }^{170}$ casa-museu do ocidente, iniciou suas atividades como museu no final do século XVIII, ao mesmo tempo que Alexandre Lenoir recolhia as obras que formariam o Museu dos Monumentos Franceses. Nasce como museu didático, espaço de docência do arquiteto professor na Royal Academy, com seu acervo composto de fragmentos que vinham em sua maioria das escavações que Johann Joachin Winckelmann ${ }^{171}$ procedia na Itália.

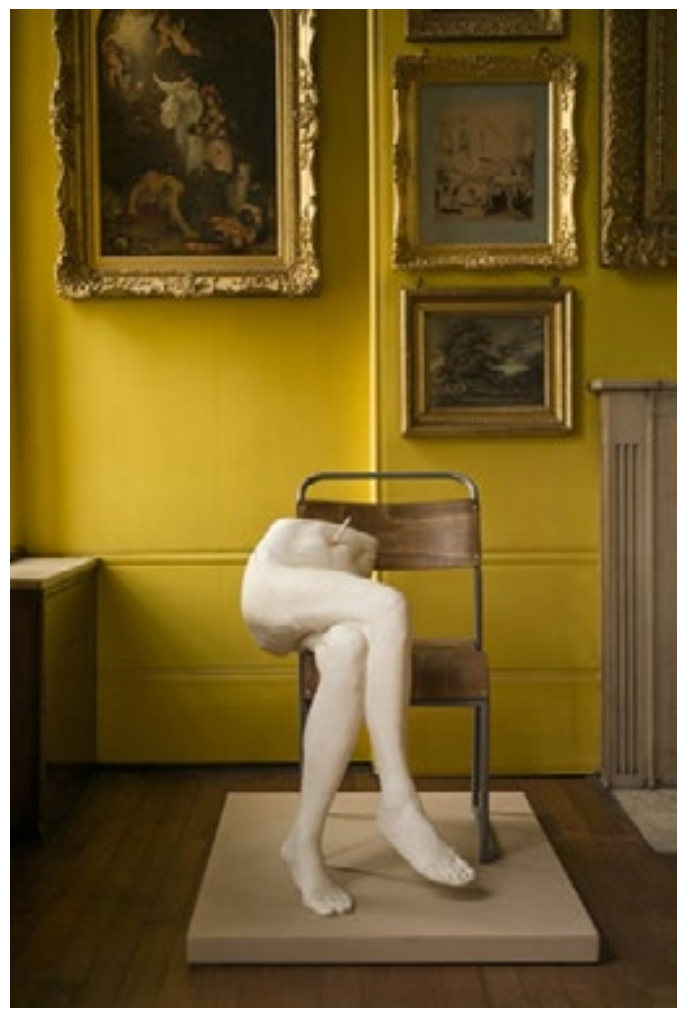

Recentemente, no ano de 2012, o Museu organizou campanha de arrecadação de fundos e restaurou todos os ambientes da área íntima de serviços da casa que nunca haviam sido mostradas ao público, com base em aquarelas feitas pelos alunos de Soane, atendendo à
Sir John Soane's Museum, exposição "Power in Woman", obra da artista Sarah Lucas. 2016. Fonte: http:// moussemagazine.it/ sarah-lucas-sir-john -soane-museum-2016/

169. As diversas alterações promovidas nos espaços do museu estão ilustradas em minha dissertação de mestrado: Arquitetura e casa-museu: conexões (Barbosa, 2013, p. 82-83).

170. Lawrence Vail Coleman escreveu Historic House Museums, em 1933, nos Estados Unidos da América, considerada uma das primeiras obras editadas sobre esta tipologia museal.

171.Johann Joachin Winckelmann (1717 - 1768), arqueólogo e historiador de arte formulou teorias sobre a relação entre arte e localização geográfica, realçando tal aspecto para valorizar o que julgava ser autêntica arte grega. Entre suas obras cito a editada em 1764, História da arte da antiguidade (Geschichte der Kunst des Altertums). 
demanda pelo interesse nos modos de vida privada do período. As novas áreas estão abertas ao público desde 2016. Este museu britânico empreende programa de ação cultural bastante amplo composto por diversas atividades direcionadas a múltiplos públicos e foi das primeiras casas-museu a se valer de exposições de arte contemporânea convidando artistas e curadores para dialogar com seu acervo. Desenvolve também programas continuados de palestras ${ }^{172}$ e pequenas mostras ligadas ao universo do design e da arquitetura conveniadas com instituições de ensino superior, colocando o museu como um lugar de leitura do futuro nestas áreas de conhecimento.

\section{Eva e Lina}

No Brasil, certas casas-museu já envidam programas sistematizados de inserção de arte contemporânea em seus espaços em ação há mais tempo, como a Casa Museu Eva Klabin no Rio de Janeiro. Outras possuem programas de arte contemporânea de frequência intermitente como a Casa de Vidro, sede do Instituto Lina Bo e P. M. Bardi. Em todas, inclusive as estrangeiras, há uma operação de atualização de questões nas propostas de site specific e de tensionamento de temporalidades, contrastando procedimentos próprios do estatuto da arte contemporânea ao tempo congelado da ambientação doméstica.

\section{Casa de vidro, São Paulo, SP}

A Casa de Vidro, segunda e atual sede do Instituto Lina Bo e P.M. Bardi173, situada no bairro do Morumbi, foi construída pela arquiteta Lina Bo Bardi entre 1950 e 1951 para servir de residência a ela e a seu marido Pietro Maria Bardi.

\footnotetext{
172. A série By Design recebeu mensalmente profissionais durante o período 2018-2019 para discutir questões ligadas ao design, as palestras são realizadas dentro do espaço do museu, em meio ao acervo de objetos colecionado por John Soane entre o final do século XVIII e início do século XIX.

173.Disponível em: <http://institutobardi.com.br/>. Acesso em: 10/01/2019.
} 


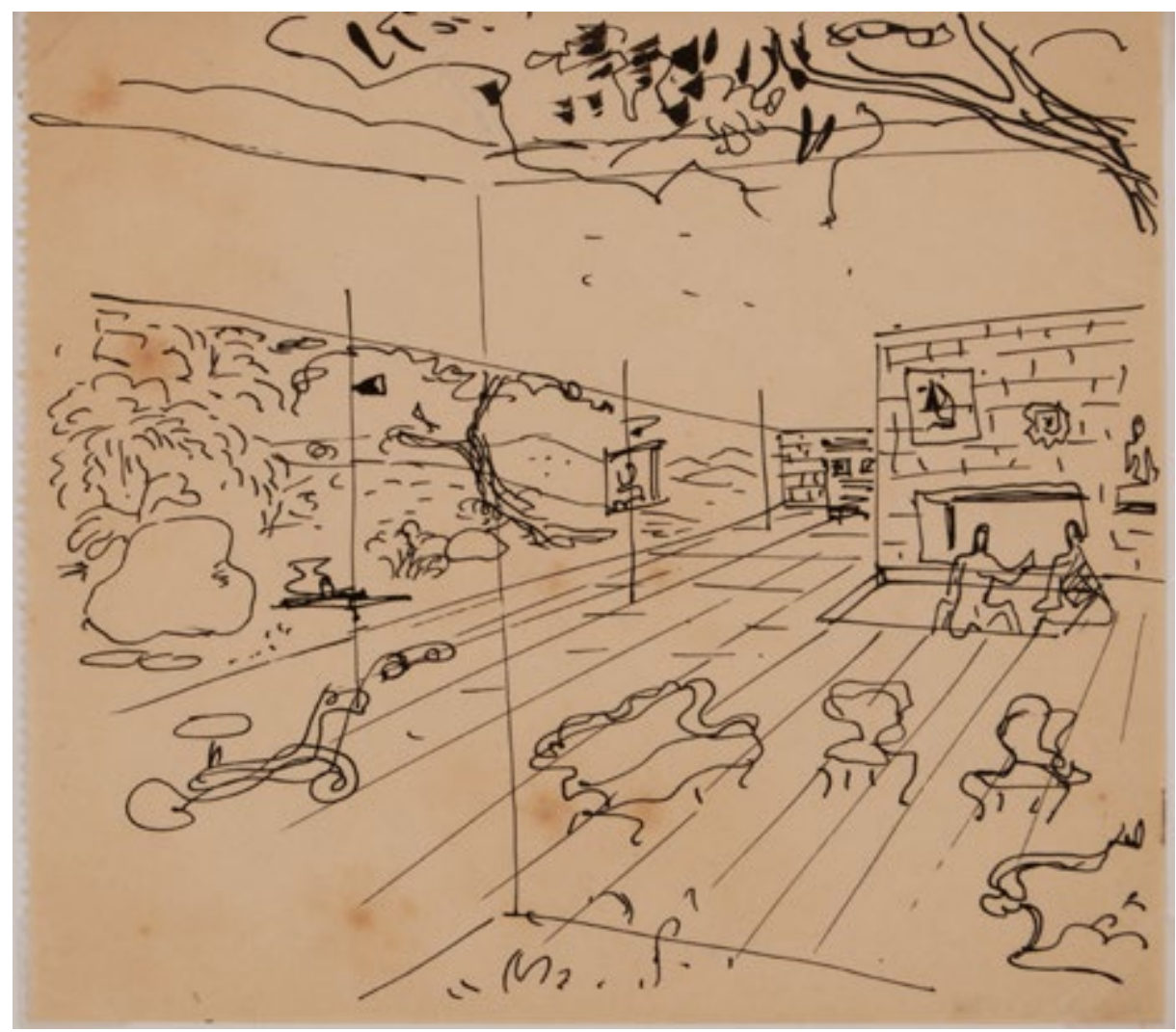

Lina Bo Bardi. Perspectiva interna da sala da Casa de Vidro, s/d. Nanquim sobre papel offset. $10,6 \times 11,8 \mathrm{~cm}$. Arquivo Instituto Bardi/ Casa de Vidro

Depois da Casa de Rui Barbosa, a Casa de Vidro é, talvez, entre as casas-museu brasileiras, a mais publicada e estudada em trabalhos acadêmicos sobre arquitetura ${ }^{174}$. Somadas a ela, a Casa Vilanova Artigas, no bairro do Brooklin; a Casa Modernista de Gregori Warchavchik, na Vila Mariana, ambas em São Paulo; a Casa de Flávio de Carvalho, na Fazenda Capuava ${ }^{175}$, em Valinhos; seguida pela Casa das Canoas de Oscar Niemeyer; e pelo sítio Burle Marx, no Rio de Janeiro, são casas-museus dedicadas a arquitetos modernos brasileiros. A segunda casa $^{176}$ do arquiteto João Batista Vilanova Artigas foi recentemente restaurada e abriga um restaurante e espaço de trabalho compartithado (co-working) à guisa de viabilização financeira. De modo oposto à casa de Lina Bo e ao Sítio Burle Marx, cujos destinos haviam sido traçados a priori por seus autores, a Casa de Flávio de Carvalho tem conseguido viabilizar manutenção mínima garantindo regime de

174.As publicações relativas à obra de Lina Bo Bardi estão listadas na Tese de Doutorado que Maíra Teixeira Pereira defendeu na UnB em 2014 (Pereira, 2014).

175. Atualmente a Casa da Fazenda Capuava, de Flávio de Carvalho, é gerida pela Associação Cultural Educacional Assistencial Capuava que desenvolve trabalhos com crianças e jovens autistas. A sede, projetada pelo engenheiro arquiteto, encontra-se em processo de tombamento pelo Condephaat e seu projeto de restauro está sendo desenvolvido pela Unicamp

176. No mesmo terreno, no bairro do Brooklin, o arquiteto construiu uma primeira casa compacta e econômica chamada de casinha, em 1949, a partir de conceitos da arquitetura orgânica de Frank Lloyd Wright. Posteriormente, em 1960, com o propósito de atender a um programa mais extenso, edificou a segunda casa de características mais racionalistas que remetem aos conceitos de Le Corbusier. No momento de coleta destes dados, a primeira casa carece de serviços de conservação. 
visitação por agendamento. A Casa Modernista de Warchavchik, da rua Santa Cruz, segue aberta em condições mínimas de manutenção, sem nunca ter tido um plano de recuperação de seu jardim, projetado por Mina Klabin, originalmente segmentado em ambientes com base em preceitos protomodernistas de vida ao ar livre e valorização do esporte. ${ }^{177}$ Já a Casa das Canoas de Oscar Niemeyer encontra-se fechada ao público e em acelerado estado de decomposição, sofrendo com os efeitos da dificuldade de viabilizar a conservação deste tipo de museu. ${ }^{178}$ Esta situação conflita com o ensejo, idealizado por Lúcio Costa e Rodrigo M.F. de Andrade à frente do SPHAN, quanto à patrimonialização de obras de arquitetura moderna brasileira, evidenciando os limites do instrumento jurídico do tombamento em face aos desafios inerentes à salvaguarda destes bens, incluindo aqueles referenciados aos seus autores.

Instituto Lina Bo e Pietro Maria Bardi, inicialmente Instituto Quadrante,

[...] foi criado em 1990 para preservar e divulgar a obra e o pensamento de Lina Bo e Pietro Maria Bardi, produzir publicações, exposições, palestras, e seminários com ênfase em arquitetura, urbanismo e design e organizar e estimular o acesso ao acervo do casal, formado por desenhos, plantas, projetos, correspondências, documentos e outros, e transformar a Casa de Vidro em um espaço de diálogo e troca de conhecimento" 179

Instituto sediado nesta casa-museu promove exposições de arte contemporânea com frequência esporádica à procura de dialogar com itens de seu acervo. Entre os eventos que promove, a exposição 0 interior está no exterior, com curadoria de Hans Ulrich Olbrist, em abril e maio de 2013, em que participaram artistas da cena contemporânea como Gilbert \& George, Dan Graham, Dominique Gonzales Forester, Ernesto Neto, Olafur Eliason, entre outros, foi a mais noticiada e que trouxe mais público à Casa de Vidro. Hans Ulrich Olbrist ${ }^{180}$ desenvolve projetos de exposições de arte contemporânea em casas-museu

177. Referência nesta área é a pesquisa de Cláudia Reis, na Casa de Rui Barbosa, no Rio de Janeiro (Reis, 2007).

178. Disponivel em: <https://www.archdaily.com.br/br/922055/casa-de-niemeyer-esta-abandonada-e-vira-palco-de-disputa-entre-familiares-e-fundacao>. Acesso em: 15/02/2020.

179.Disponivel em: <http://institutobardi.com.br/?page_id=145>. Acesso em: 14/07/2018. 0 acervo do Instituto Lina Bo e P.M. Bardi conta com 10.000 documentos, 6.633 desenhos, 15.000 fotografias e 195 obras de arte, além de itens de mobiliário, livros, prataria, objetos de arte popular de propriedade do casal.

180. Hans Ulrich Olbrist (1968) é curador de arte suiço, crítico e historiador de arte, diretor artístico da Serpentine Galleries, em Londres, autor do The Interview Project, um extenso projeto em andamento de entrevistas com personagens do mundo da arte contemporânea e museus. Ele também é coeditor da revista Cahiers d'Art. 
pelo mundo, entre elas, Sir John Soane Museum, em Londres, Reino Unido; Nietzsche Haus, em Sils Maria, Suiça; Casa Luís Barragán, na Cidade do México; Casa-museu Federico García Lorca, em Granada, Espanha. Embora não seja o único curador a fazê-lo, sua projeção no circuito de arte internacional confere credibilidade, divulgação e consequente afluxo de público.

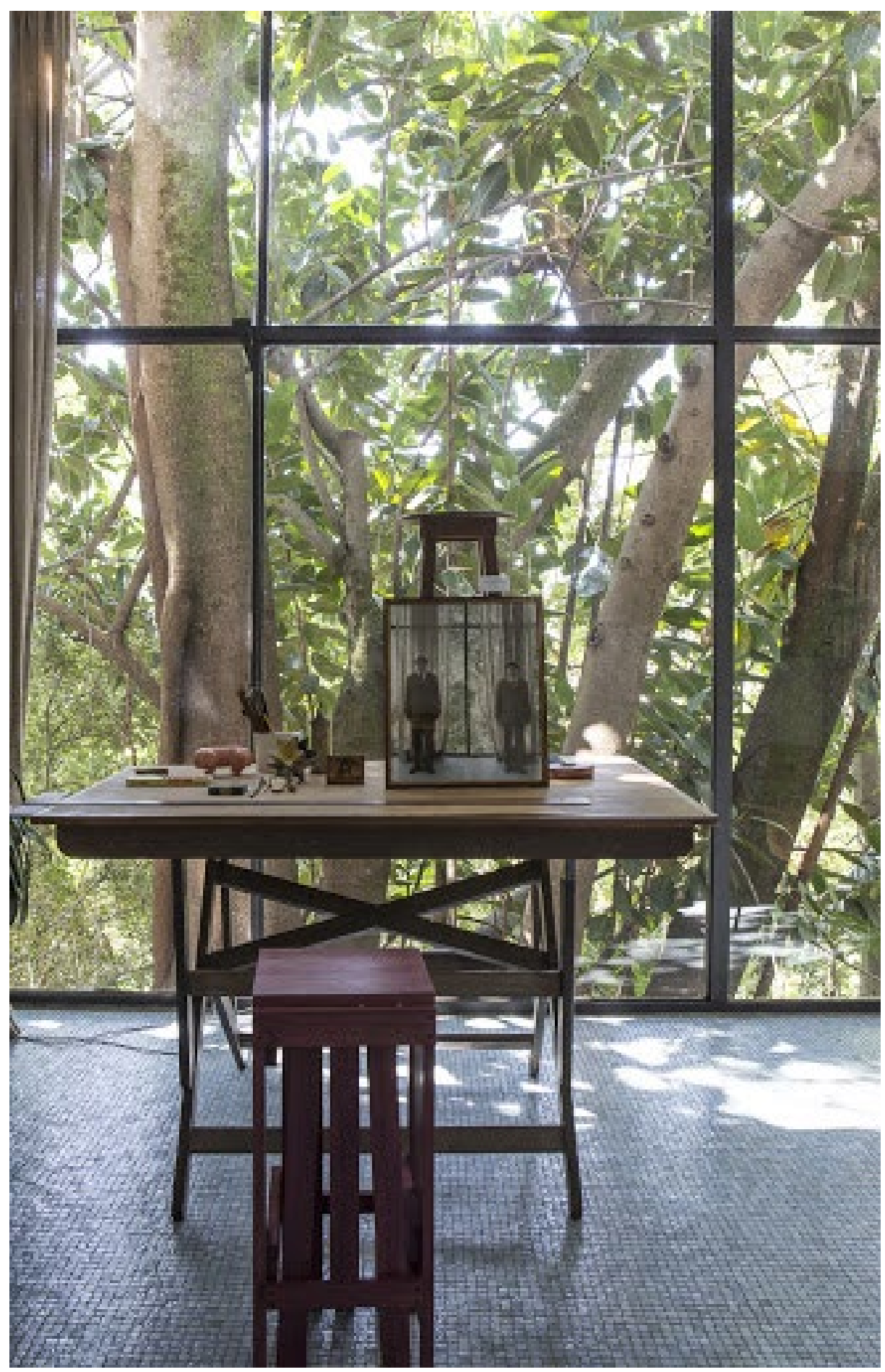

Fig. 45 - $\quad$ Casa de Vidro, exposição "O interior está no exterior" curadoria Hans Ulrich Olbrist. Instalação de Gilbert \& George. 2013. Fonte: http:// www.ovitro.com. br/2013/05/24/casa-de-vidro-_-hans-ulrich-obrist-the-insides-are-on-the-outside-_-morumbi/ 
Fig. 46 - Casa de Vidro. Fachada. 2017. Foto A.

A farta historiografia sobre a residência da arquiteta a aproxima de obras coetâneas como a residência Farnsworth ${ }^{181}$, em Illinois, obra do arquiteto alemão Mies Van der Rohe, e a Glass House, em Connecticut, do arquiteto estadunidense Phillip Johnson, ambas nos Estados Unidos da América. Em sua concepção foi dado tratamento diferenciado entre as áreas. A social, composta por sala de estar, jantar e biblioteca, conforma um volume prismático com piso em pastilha vitrica azul claro elevado sobre o terreno por pilares metálicos, cercado de grandes panos de vidros transparentes e entremeado por vazio atravessado por grande árvore.

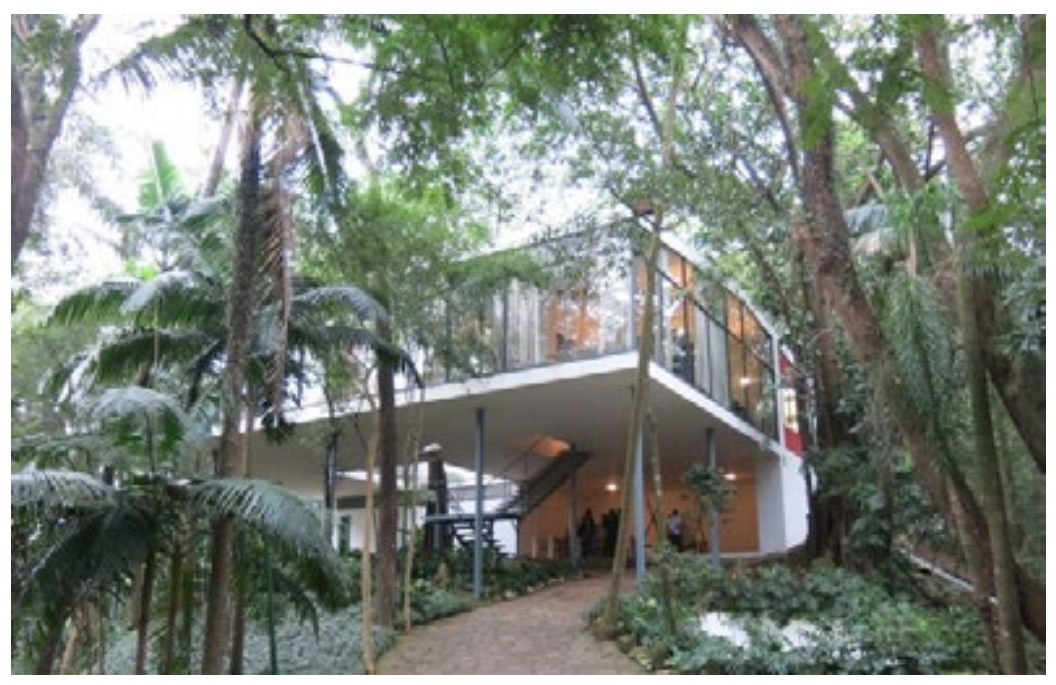

Este se oferecia à cidade como posto privilegiado de observação, hoje encoberto pela densa vegetação plantada intencionalmente para reconstituir a paisagem natural da Mata Atlântica, devastada pela atividade agrícola anterior. A cozinha torna-se área de interesse em face das originais soluções de coifa, armazenamento, mobiliário e iluminação aliadas ao uso precoce de eletrodomésticos ${ }^{182}$, e liga-se à área de serviços que conforma, assim como a área íntima da casa, volume de proporções bastante vernaculares destinado ao abrigo de funções domésticas e de empregados, apoiado no terreno reproduzindo um dado modo de morar.

181.A residência Farnsworth, próxima ao rio Fox, em que Mies conseguiu colocar em prática conceitos como: beleza, cristalinidade, rigor, ordem, regularidade e precisão, foi objeto de polêmica a partir de contenda judicial entre o arquiteto e a proprietária, que alegava não ser possivel viver na casa. Foi também usada como exemplo nas críticas que Frank Lloyd Wright teceu aos arquitetos modernistas. As frequentes inundações a que a casa está sujeita suscitaram projeto de captação de recursos para a instalação de elevadores hidráulicos destinados a sua preservação.

182. O interesse de Lina Bo Bardi no funcionamento da casa moderna se evidencia desde seus artigos publicados nas revistas italianas de que participou e em que conclamava a mulher dita moderna a enfrentar o trabalho doméstico "da mesma forma que os operários enfrentavam o trabalho de uma fábrica", de forma racionalizada. 


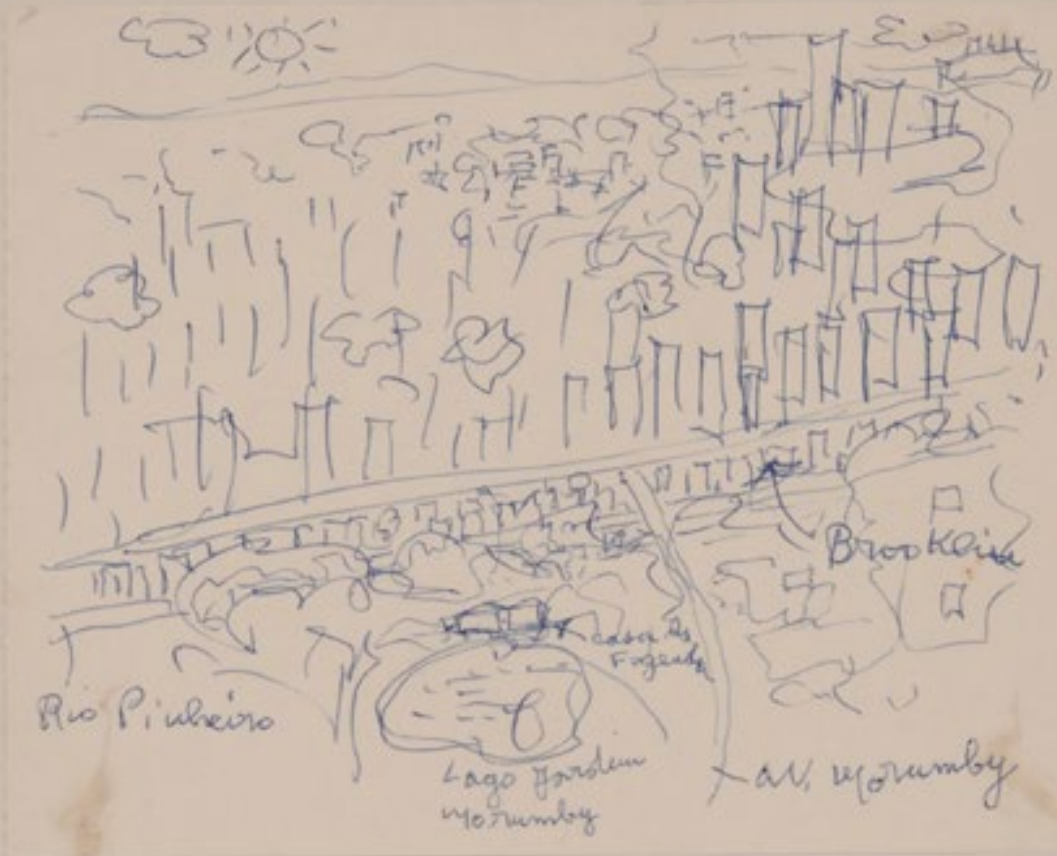
cidade de São Paulo, s/d. Esferográfica e grafite sobre papel offset. 11,5 x 14,2 cm. Arquivo Instituto Bardi/ Casa de Vidro.

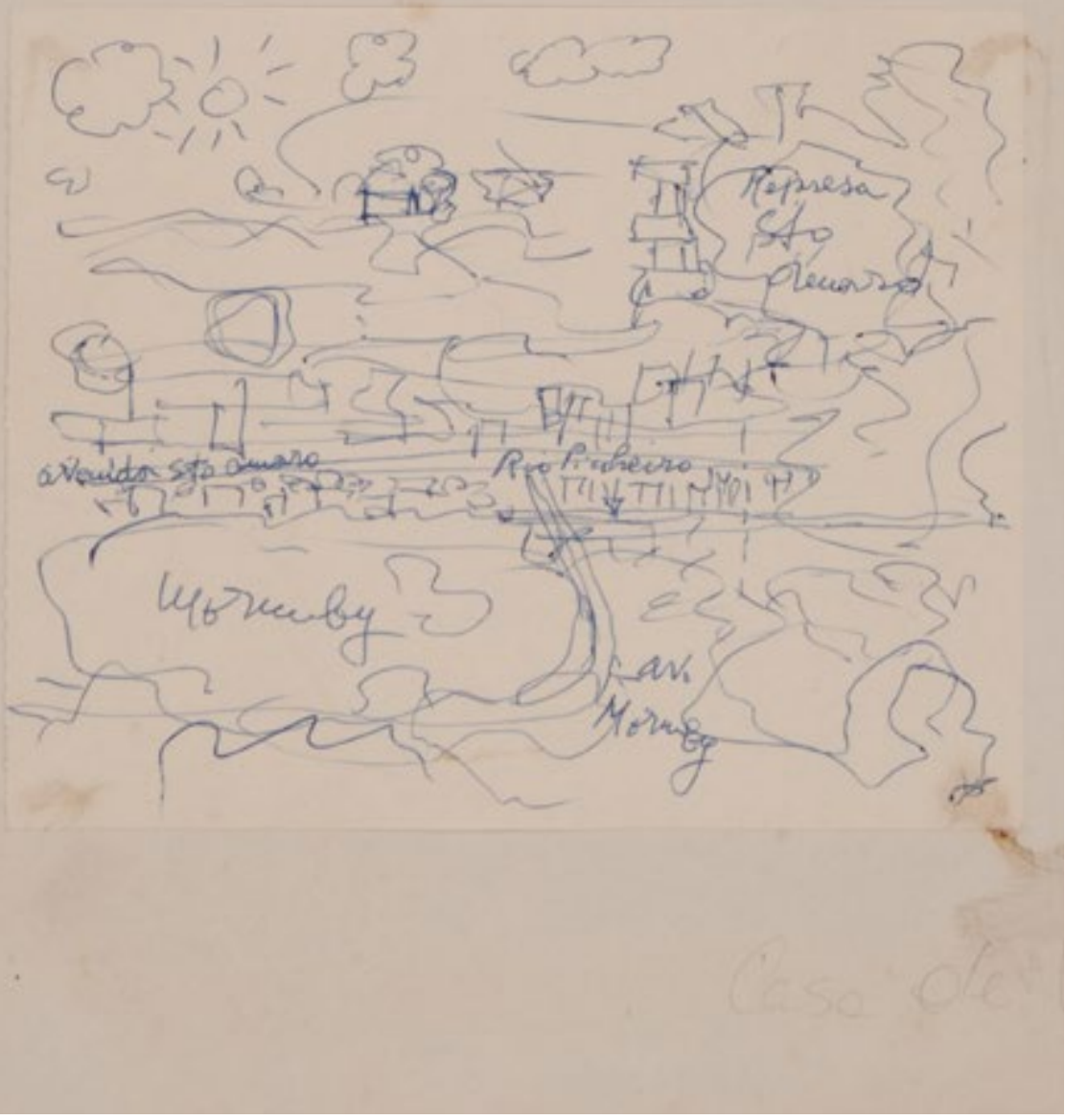


A casa, exemplar a exprimir certa visão idealizada do acesso à natureza próprio ao olhar estrangeiro do casal, centrado na ambiência e na paisagem tropical, em sua duplicidade de escalas, tem servido de espaço experimental à arte site specific, nas exposições que realiza, podendo se valer de maior regularidade no calendário destes eventos como maneira de potencializar sua ação museal.

\section{Casa da Fundação Eva Klabin, Rio de Janeiro, RJ}

Pioneira no Brasil na exposição de obras de arte contemporânea em diálogo com o espaço e o acervo, a Casa Museu Eva Klabin ${ }^{183}$ promove, desde 2004, o programa de intervenções de arte contemporânea denominado Projeto Respiração, concebido pelo curador da casa, Marcio Doctors ${ }^{184}$. Neste programa de intervenções, o mais antigo e regular no Brasil, a casa-museu, que detém uma rara e diversificada coleção de arte clássica e arqueológica, vem sistematicamente expondo seu espaço à fricção proposta por artistas contemporâneos como meio de "atualizar para as novas gerações o sentido de uma coleção - um importante legado de história da arte e de uma vida representativa de uma época" (Doctors, 2012, p. 26). As oficinas do Projeto Respirações, em convênio com a Secretaria de Estado da Cultura do Rio de Janeiro, promovem a inclusão de comunidades carentes da cidade, propondo a utilização da "arte como instrumento de reflexão e de mudança de seu entorno" (Doctors, 2012, p. 27).

Fig 48 - Fundação Eva Klabin, Rio de Janeiro, RJ. Fachada com intervenção da artista Regina Silveira. Projeto Respiração 21a edição 27 de setembro de 2016 a 29 de janeiro de 2017. Fonte: encurtador. com.br/qKLRU

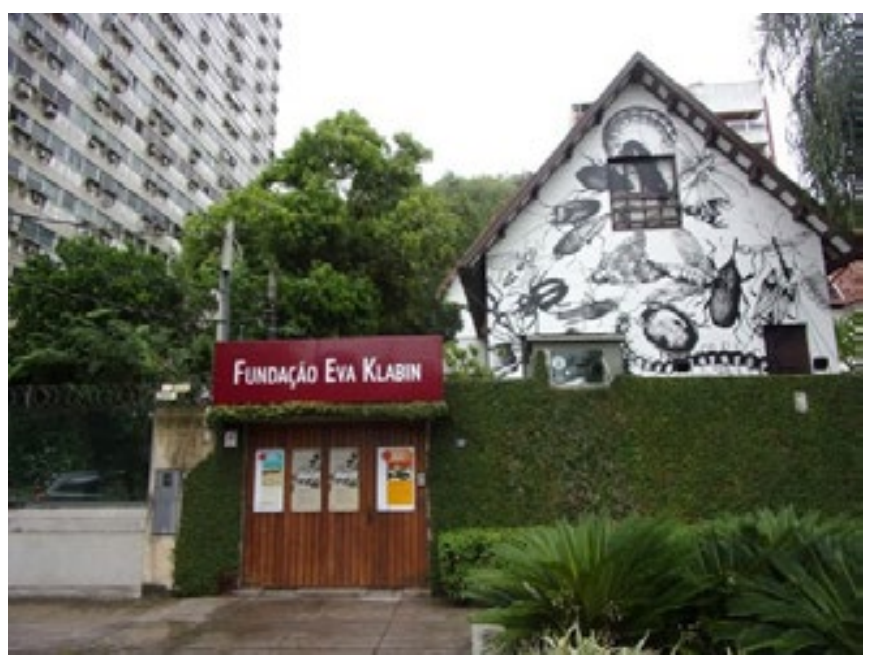

\footnotetext{
183. Uma das poucas instituições brasileiras a adotar a mesma acepção que defendo neste trabalho em detrimento das muitas que se utilizam da forma museu-casa.

184. Marcio Doctors é doutorando em filosofia pela Universidade do Estado do Rio de Janeiro, foi secretário particular do crítico Mário Pedrosa depois de seu retorno do exílio, concedeu entrevista a esta pesquisa na casa-museu Fundação Eva Klabin, no Rio de Janeiro, em outubro de 2017.
} 
A casa sede da Fundação Eva Klabin, na Lagoa Rodrigo de Freitas, no Rio de Janeiro, foi inicialmente alugada por Eva Klabin e seu marido, Paulo Rapaport ${ }^{185}$, no final dos anos 1940. Situada à beira da Lagoa situava-se numa região ainda não muito valorizada da cidade, em processo de ocupação após a abertura do Corte do Cantagalo. O casal desmembrou e comprou, em 1951, parte do terreno vizinho que era de Filinto Muller, chefe de polícia do Estado Novo, já com a intenção de ampliar a casa adquirida, em 1952, em estilo típico normando, datada de 1931. Durante os anos 1960, já viúva, Eva empreendeu grande reforma para ampliar a casa e receber sua coleção de arte, que guardava em outro imóvel, na avenida Atlântica. Os espaços são especialmente desenhados em função da coleção, o que atesta a intenção de tornar a casa um museu, pois estas opções já envolvem certa visão relativa ao circuito de visitação e de periodização da extensa coleção que percorre a História da Arte desde a antiguidade. Após a reforma, a casa conta com 1.000 m² de construção. Em 1990 criou a Fundação Eva Klabin e a deixou para a cidade do Rio de Janeiro, um ano antes de falecer. Para a presidência da Fundação, nomeou o cientista político Hélio Jaguaribe ${ }^{186}$ e, como curador, Paulo Herkenhoff ${ }^{187}$, que ao se desligar para assumir a curadoria da 18 São Paulo, Antropofagia, em 1998, indicou o curador Marcio Doctors, que permanece até hoje à frente dos projetos da Fundação.

○ Projeto Respiração, como programa de intervenções de arte contemporânea na Casa Museu Eva Klabin, é justificado também como alternativa à ampliação de público, principalmente o não especializado em História da Arte, como maneira de tornar a casa-museu espaço de visitação plural, escapando da sina de visita-única e oferecendo outras possibilidades de leitura da coleção. Doctors afirma que entre as intenções está a possibilidade de "[...] criar novas experiências

185. Paulo Rapaport era advogado, austríaco naturalizado brasileiro, e trabalhava como jornalista nos Diários Associados junto de Assis Chateaubriand.

186. Hélio Jaguaribe Gomes de Mattos (1923-2018) foi um advogado, sociólogo, cientista político e escritor brasileiro, professor em universidades brasileiras e norte-americanas, fundador do PSDB

187. Paulo Estellita Herkenhoff Filho (1949) foi o primeiro Diretor Cultural do Museu de Arte do Rio, o MAR, bem como Diretor-Geral do Museu de Belas Artes do Rio de Janeiro (20032006) e Curador-Chefe do Museu de Arte Moderna do Rio de Janeiro, o MAM-RJ (19851999). Além disso, foi Curador Adjunto no departamento de pintura e escultura do Museu de Arte Moderna de Nova Iorque, o MoMA (1999-2002), Curador Geral da XXIV Bienal de São Paulo (1997 e 1999) e Curador da Fundação Eva Klabin Rapaport. Foi Consultor da Coleção Cisneros (Caracas, Venezuela) e Consultor da IX Documenta Kassel, na Alemanha (1991). Realizou curadorias consideradas centrais para a compreensão histórica da produções em arte brasileira e latino-americana, como o Pavilhão brasileiro na 47a Bienal de Veneza (1997), exposição de formato fundador realizada em instituição de prestígio mundial; foi curador geral da 24aㅡ edição da Bienal de São Paulo (1998), Um e/entre Outros, conhecida como a Bienal Antropofágica. Disponivel em: http://www.forumpermanente. org/convidados/p_herkenhoff>. Acesso em: 12/12/2019. 


\section{Arte site-specific}

De fato, a arte site specific representou, no início dos anos 1960, um deslocamento do espaço estéril, puro e idealizado do modernismo na direção do espaço da natureza e também do espaço impuro do cotidiano. Autores que se debruçam sobre este tema afirmam que entre as razões do apego da arte a este novo estatuto estava responder, entre outras questões, a um modelo que propiciasse a experimentação corporal, vivenciada da arte, e que resistisse às forças do mercado. Embora a arte site specific tenha ao longo dos anos ampliado o conceito de site, na direção de sua desmaterialização, fazendo com que este alcançasse dimensões cada vez menos físicas, concebendo-o de forma mais textual que espacial, incluindo entre os novos sites, de acordo com Kwon, os debates culturais, conceitos teóricos, questões sociais e políticas, estruturas institucionais, comunidades ou convenções históricas, reconhece que "um impulso dominante de práticas orientadas para o site, hoje é a busca de maior engajamento com o mundo externo e a vida cotidiana." (Kwon, 2008, p. 171).

Fig. 49 - Freud Museum, Londres, Reino Unido. Intervenção de Miroslaw Balka Die Traumdeutung. 2014. Fonte: https://www.freud. org.uk/exhibitions/ miroslaw-balka-die-traumdeutung/

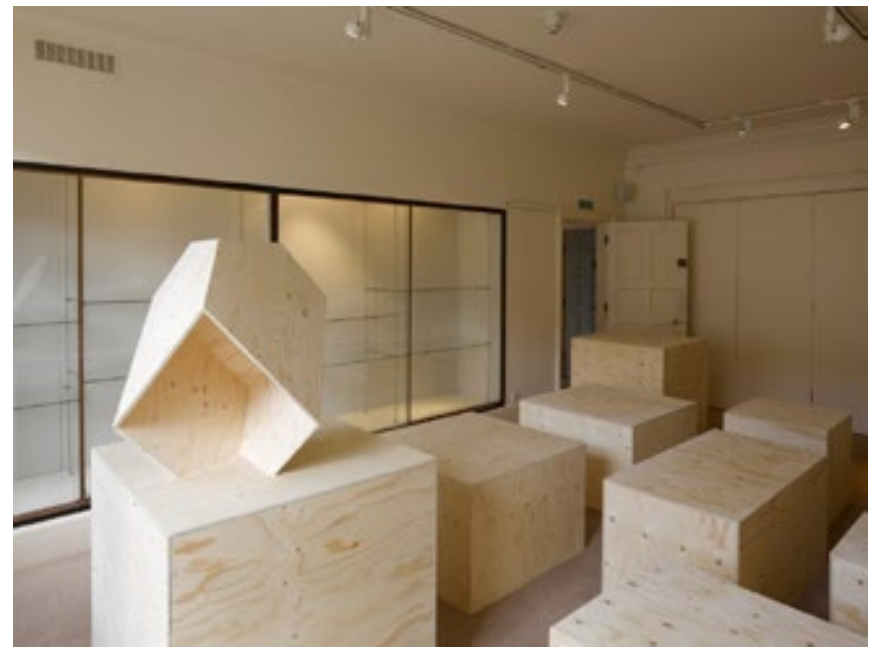

Os trabalhos de arte contemporânea inseridos no espaço da casa-museu operam em todas as dimensões do site que a teoria da arte site specific identifica, tais como o fenomenológico, representado pela relação com o espaço e materialidade da casa e de sua coleção (eventualmente de arte); social/institucional, dadas as bases contratuais desta intervenção que serão sempre negociadas; e discursivo, 
denotado pela textualidade, pela narrativa do artista. Desta forma imprimem um tempo presente à casa-museu, oferecem questões do tempo do agora, oferecendo alternativas de deslocamento de temporalidades mitificadoras contidas no plano museológico. Surgem, desta maneira, como possibilidade de leitura de possíveis futuros, realizando a missão do museu na atualidade. 


\section{FUNDAÇÃO}

\section{EVA KLABIN}

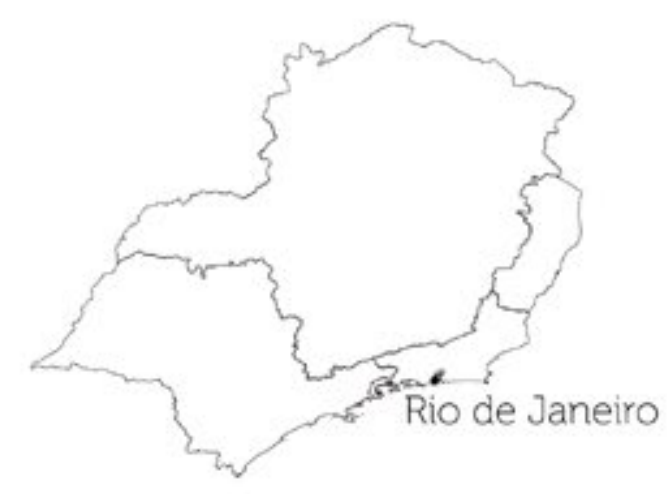
Endereço:
Av. Epitácio Pessoa, 2480
- Lagoa

Cidade:

Rio de Janeiro

Arquiteto:

Data de construção:

1931

Periodo(s) de reforma:

1960

Técnicas construtivas

Estrutura mista de concreto e alvenaria.

Dados da casa-museu

Inauguração

1995

Área do terreno: $\quad 1009,42 \mathrm{~m}^{2}$

Pavimentos: $\quad T+1$

Área do térreo $\quad 1009.42 \mathrm{~m}^{2}$

Área do $1^{\circ}$ pav: $\quad 620,96 \mathrm{~m}^{2}$

Área total: 


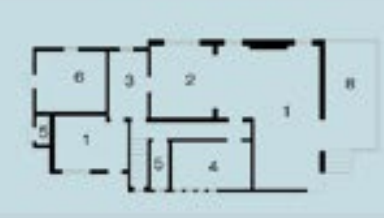
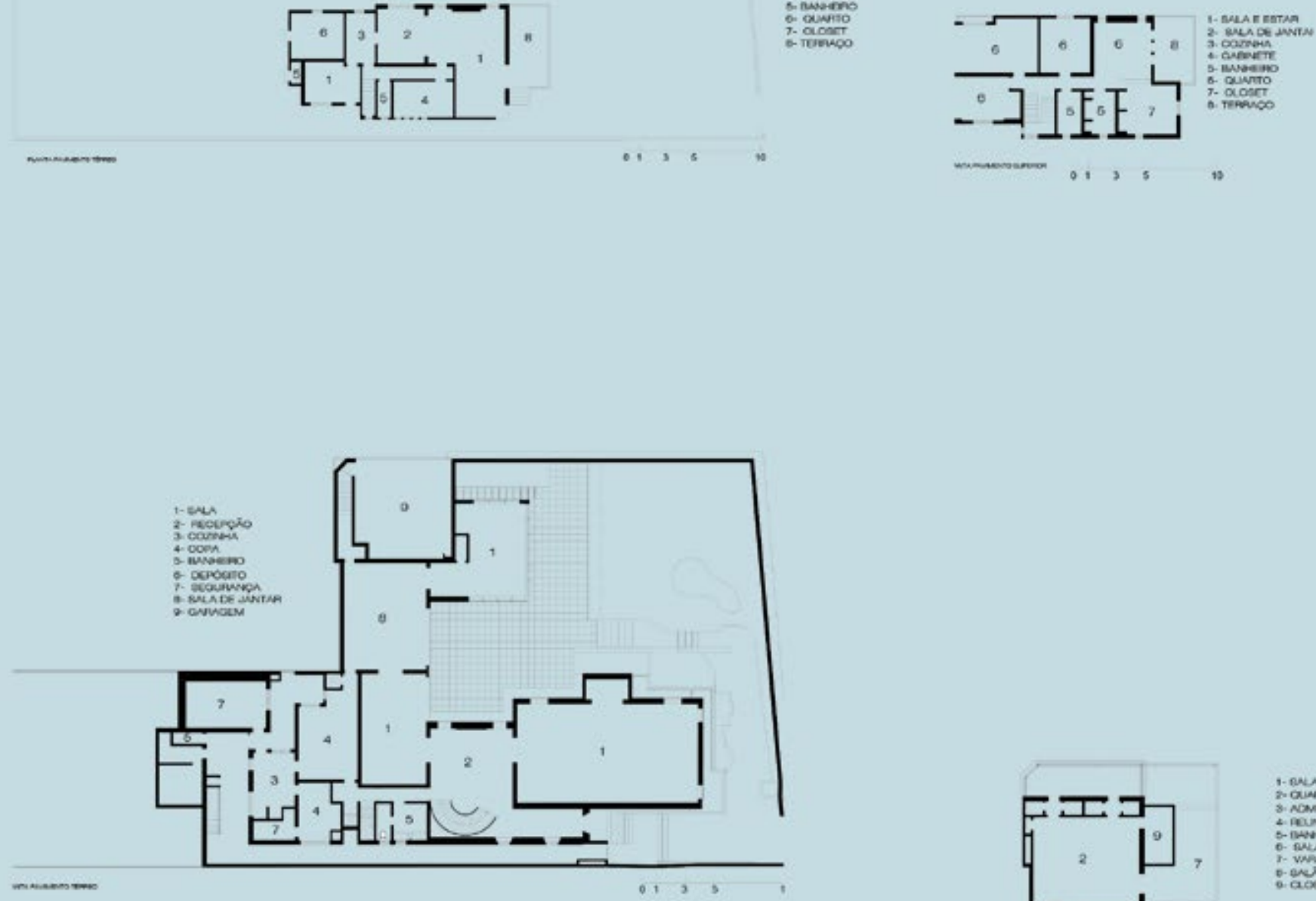

t. Danerer

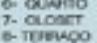
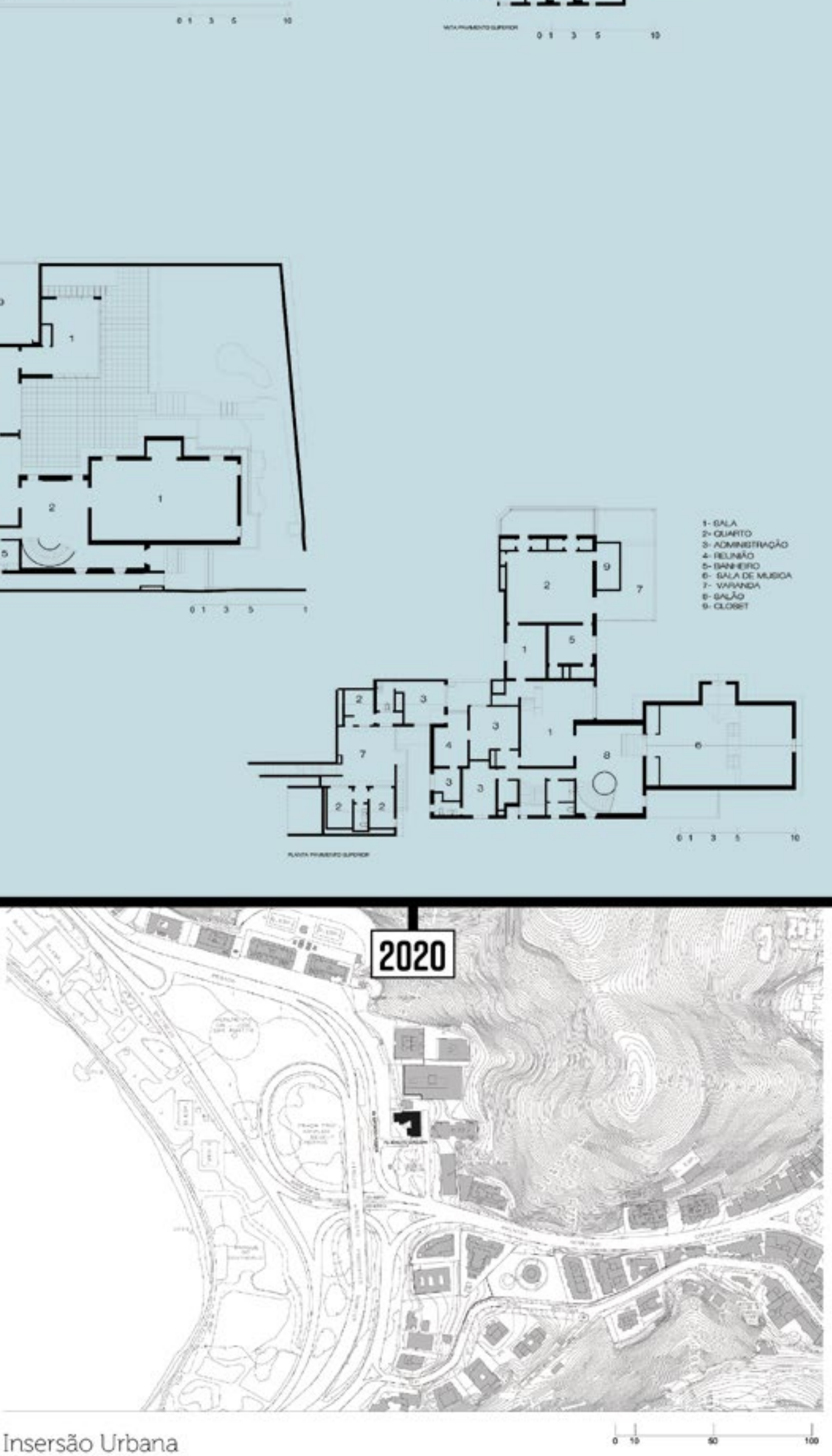


\section{Conclusões}

$\bigcirc$ presente trabalho buscou oferecer diferentes interesses, para além daqueles que me moveram, constituindo em sua organização, conteúdo e referências, fonte de outras pesquisas para variadas áreas do conhecimento, como maneira de realizar seu propósito acadêmico. Procurou-se defender o esgarçamento de limite entre áreas e implementar processos museais trazendo questões candentes de cada tempo e lugar.

O conjunto de elementos apresentados comprova que uma residência construída a partir de específica lógica de produção, inserida em dada cidade e momento histórico, testemunha condições técnicas, anseios, domesticidade e formas de representação próprias à arquitetura e ao urbanismo, e, ao tornar-se museu, assume significações diversas ao subverter a experiência espacial expondo-se a fruição de distintos receptores e vinculando-se a outras instituições na malha urbana. Este processo de relação de contiguidade implica interação em dado território, recriando a ordem local de modo a configurar posição de resistência àquela global.

Expõem-se a situações singulares a mesma materialidade, arquitetura e cidade. De um uso mais restrito, privado, passa a outro ampliado, público. $\bigcirc$ visitante tem experiência espacial fundada em repertório pregresso que, friccionada à vivência da casa-museu percorrida em totalidade, suscita a afecção de todos os sentidos por meio da diferenciação de escalas, percursos, luminosidade, acústica, incluindo sistemas de representação e universo simbólico, possibilitando conhecimento acerca da casa e da cidade. O espaço vivenciado é o pensado por Zevi à medida que reincorpora a presença do homem na experiência espacial reconhecendo como natural que o espaço, o vazio, seja o protagonista da arquitetura, entretanto "[...] a arquitetura não é apenas arte, nem só imagem de vida histórica ou de vida vivida por nós e pelos outros: é também e sobretudo, o ambiente, a cena onde vivemos a nossa vida." (2009, p. 28).

O expressivo e variado conjunto de casas-museu permitiria leitura de acervo já existente, exposto sistematicamente a nova significação, realizando o processo museal ao ressemantizar o objeto Casa em sua relação com a cidade. Ao adentrar o museu, o objeto submete- se a processos de conservação imbuídos da intenção de retardar a sua obsolescência, para se expor à recepção de visitantes, pesquisa, produção de conhecimento e significado sobre ele. Significado móvel e variável em função do tempo. Este conjunto de casas-museu a 
homenagear figuras públicas, artistas, coleções, sob o olhar da arquitetura e do urbanismo, informado pelo levantamento da residência, lote e cidade em que está inserida, constituiria também, potencialmente, rede a testemunhar modos de vida e urbanidade que dialeticamente se produzem conformando importante instrumento em variados atributos inclusive didáticos

Propusemos valorização da tipologia casa-museu, ao qualificar museu, arquitetura e arte desta época, como se observou na análise da casa-museu que propicia atualização por meio da inserção da arte contemporânea. Algumas iniciativas, na construção de rede constituída por casas-museu, já são observáveis, no caso da rede de museus literários, recentemente contemplada com recursos estaduais para a restauração e reforma da Casa das Rosas. Dada a brevidade de sua instauração ainda não se concretizaram plenamente as necessárias trocas com aquelas outras instituições culturais existentes no entorno. O momento de debates sobre a definição de museus, ora em curso, como se viu, por certo colaborará para ampliar tais relações e estudos, colaboração seminal, que poderá ser ativada em universidades, de modo a aprofundar a relação entre cidade e urbanidade.

Os museus, desde seu surgimento no século XVIII na Europa, estiveram fortemente aderidos ao conceito educacional e didático e a partir do século XIX eram orientados a ser razoavelmente acessíveis, administrados por mais de uma pessoa em benefício do público, arranjados de forma sistemática e não arbitrária de modo a contribuir com o conhecimento por meio do estudo de suas coleções, revelando um alto grau de idealismo nesta concepção. Assim procurou-se demonstrar que as casas-museu encontram-se fortemente vinculadas a seus territórios, que resultam em complexidades de leituras vinculadas a sistemas de representação e repertórios simbólicos, centrais na interpretação de suas coleções. Benjamin afirma que o fato de o colecionador retirar o objeto de suas relações funcionais não seria suficiente para explicar a fundo o comportamento do colecionador, que o autor classifica como singular, mas, sim, a possibilidade de construção de um sentido subjetivo incompreensível aos outros. Fala aqui da formação de coleções no início do século XX, cujas práticas se acentuam na atualidade, dada a profunda modificação nos sistemas de mercado e de comunicação.

Se outros tipos de museus se instalam em edifícios diversos, adaptados à nova função ou em construções especialmente projetadas para este fim, o espaço da casa-museu, objeto desta investigação, deles se distingue por 
ser item de acervo. Frequentemente, para realizar sua missão, a casa-museu se vale de espaços em imóveis contíguos ou próximos, de maneira a preservar escala e ambiência que testemunhem domesticidade. A arquitetura da casa e sua implantação no lote configuram o bairro e sua relação com a cidade, mediada pelos jardins, documentando a cartografia social e econômica das aglomerações urbanas, tão desiguais no Brasil. Ativada como museu da habitação e da cidade, atribuem-se novas camadas de operação museal à casa-museu, para além da mitificação centrada na reificação da personagem que homenageia, qualificando a materialidade da Casa a recepções diversas, como meio de realizar, entre outros, o direito à cidade.

Deste modo procurou-se ratificar outras probabilidades que se abrem ao desempenho da casa-museu no reconhecimento relativo à potência da ação realizada pelas camadas populares na construção de um novo entendimento sobre a cidade, a demandar de equipamentos e instituições voltados à memória, realinhamento de posturas e procedimentos capazes de enfrentar o profundo alheamento a que estão submetidas e que reverberem o embate entre os tempos de ação e memória.

A tangibilidade de uma casa documenta para além de modos de produção, os de habitar e de ver o mundo, intrinsecamente ligados à cultura urbana. Revelam, portanto, o protagonismo do lugar, em sua impossibilidade de homogeneização, a realidade dos territórios e contingências do meio associado, como resistência ao domínio do mundo expresso por relações de sobreposição cultural e econômica. Por meio dos conceitos trabalhados, o lugar se apresenta dependente da totalidade de lugares que constroem o espaço, definido como conjunto de elementos formais a remeterem por analogia, figuração e convenção a relações sociais do passado e do presente e por uma estrutura representada por relações sociais contemporâneas manifestas por meio de processos e funções.

Orelato da casa-museu se constrói, assim, no arranjo de objetos, móveis, distribuição dos ambientes, percurso sugerido ao visitante, arquitetura do edifício em sua expressão, implantação no terreno e localização na cidade. Dada que a composição destes elementos está sujeita a regras dinâmicas que ensejam procedimentos, a incluir a recepção como processo sempre renovado, dinâmico, produtivo e dilatador, seria o encontro dialético entre a experiência estética propiciada pela casa-museu e repertório pregresso do receptor a motivadora de novas relações entre visitante e museu. 
Desta maneira, o culto ao passado, à celebridade, daria lugar a novas apropriações da casa, atualizadas pela representação do tempo, agindo na fronteira entre as artes. Modos de visualização do passado se confrontariam com modos de visualização do presente no espaço da casa, cenário de permanências dado pelo testemunho da arquitetura e do urbanismo. O que fica são as paredes/jardins que acomodam espaços/cenários para outras questões. Na casa-museu, seu edifício, localização no bairro e na cidade, são dados de antemão, incorrendo em complexidade específica ao conferir condição de acervo a estas categorias. Na contemporaneidade ao invés de comportar um novo e único foco, a casa se torna polissêmica, abre-se a interpretações, escapando do historicismo ao retirar a casa-museu do limbo em que muitas se encontram, oferecendo perspectivas além do pitoresco, do raro, do extraordinário. Cientes de que a contemporaneidade é uma relação singular com o próprio tempo, como afirma Agamben, "[...] que adere a ele e, ao mesmo tempo toma distância dele" (2015, p. 22).

De fato, a ação numa casa-museu, muitas vezes, está limitada por estatuto, tendo em vista os díspares objetivos expressos na constituição de tão variado conjunto. Esta tese propõe a ampliação das possibilidades de atuação institucional a partir da multiplicidade de públicos e de abordagens focadas na materialidade da arquitetura e seus atributos, desnaturalizando a habitação da personagem homenageada ao conectá-la a outras esferas de significação, inseridas em chaves coletivas como o processo de produção do espaço da cidade, de modo a obter maiores recursos e diálogo com variados segmentos.

Como é possível à casa-museu dar conta das questões do presente? Na contemporaneidade, faz-se premente propiciar novas articulações entre passado e futuro também por meio de instituições e equipamentos culturais voltados à preservação de memórias, considerando a conexão entre patrimônio, território e memória como "vetores da identidade" (Hartog, 2006, p. 266).

Esta possibilidade é característica específica desta tipologia museal, dada sua essência centrada na reprodução de um real, marcado pela pluralidade de informações, escalas e objetos, que cumprem função de semióforo, permitindo que se realize o processo de atualização, no sentido que esta ação é entendida na interpretação oriental dada ao patrimônio, da memória viva, vivenciada, contribuindo para a ativação de vasto e variado conjunto já existente na inserção do homem urbano na cultura da cidade e na qualificação potencializada da casa-museu pelo trabalho em rede. 


\section{Bibliografia}

ACAYABA, M. M. Branco e Preto: uma história do design brasileiro nos anos 50. São Paulo: Instituto Lina Bo e P. M. Bardi, 1994.

AGAMBEN, G. El hombre sin contenido. Barcelona: Áltera, 2005 A.

que é um dispositivo. outra travessia, Florianópolis, p. 9-16, jan 2005 B. ISSN 2176-8552. Disponível em: <https://periodicos.ufsc.br/index.php/Outra/ article/view/12576/11743>. Acesso em: 12/10/2018

Nudez. Belo Horizonte: Autêntica, 2015.

A comunidade que vem. Belo Horizonte: Autêntica, 2017.

O fogo e o relato: ensaios sobre criação, escrita, arte e livros. São Paulo: Boitempo, 2018.

ARANTES, A.A. Documentos históricos, documentos de cultura. In. In Revista do IPHAN, n은 22, p. 48-55. 1987

AUGÉ, M. Não lugares: introdução à antropologia da supermodernidade. Campinas: Papirus, 1994.

As formas do esquecimento. Almada: Íman, 2001.

BACHELARD, G. A poética do espaço. São Paulo: Abril Cultural, 1984.

BANHAM, R. A home is not a house. Art in America, abril 1965.

BANN, S. Visões do passado: reflexões sobre o tratamento dos objetos históricos e museus de história. In: As invenções da história: ensaios sobre a representação do passado. São Paulo: Unesp, 1994. p. 153-173.

BANN, S. A way of life: thoughts in the identity of the house museum. Acts of The Annual Conference - International Comitee Demhist. [S.l.]: [s.n.]. 2000.

BARBOSA, P. E. Arquitetura e casa-museu: conexões. (2013). Dissertação (Mestrado em Arquitetura) - Faculdade de Arquitetura e Urbanismo da Universidade de São Paulo-FAUUSP, São Paulo, 2013. (Área de Concentração - Projeto, Espaço e Cultura - PEC). 
BENJAMIN, W. Passagens. São Paulo: Imprensa Oficial, 2009.

BLOOM, P. Ter e manter: uma história íntima de colecionadores e coleções. Rio de Janeiro: Record, 2003.

BORRIAUD, N. Estética Relacional. São Paulo: Martins Fontes, 2009.

Pós-produção: como a arte reprograma o mundo contemporâneo. São Paulo: Mrtins Fontes, 2009.

Radicante. São Paulo: Martins Fontes, 2011

BRASIL, M. I. Informatização do acesso aos acervos bibliográfico, arquivístico e museológico da Casa de Rui Barbosa. Fundação Casa de Rui Barbosa. Rio de Janeiro. 2000. Disponível em: <http://www.casaruibarbosa.gov.br/dados/ Doc/artigos>. Acesso em: 10 nov. 2017.

BRYSON, B. Em casa - uma breve história da vida doméstica. São Paulo: Companhia das Letras, 2011.

CALINESCU, M. Five faces of modernity: Modernism, Avant-Garde, Decadence, Kitsch, Postmodernism. Durham: Duke University Press, 1988.

CANCLINI, N. G. A globalização imaginada. São Paulo: Iluminuras, 2007.

CARVALHO, A. C. (Org.). Museus-casas históricas no Brasil. São Paulo: Curadoria do Acervo Artístico Cultural dos Palácios do Governo do Estado de São Paulo, 2013.

CARVALHO, R. M. R. D. As transformações da relação museu e público: a influência das tecnologias da informação e comunicação no desenvolvimento de um público virtual. (2005). Tese (Doutorado em Ciência da Informação) Instituto Brasileiro de Informação em Ciência e Tecnologia-IBICT e Escola de Comunicação-ECO da Universidade Federal do Rio de Janeiro-UFRJ, Ministério da Ciência e da Tecnologia-MCT, Rio de Janeiro, 2005.

CASTELLS, M. A sociedade em rede. São Paulo: Paz e Terra, 2000.

CASTRO, A. C. V. Um americano na metrópole (latino-americana). Richard Morse e a história cultural urbana de São Paulo, 1947-1970. (2013). Tese (Doutorado em Arquitetura). Faculdade de Arquitetura e Urbanismo da Universidade de São Paulo-FAUUSP, São Paulo, 2013. 
CASTRO, E. D. Introdução a Giorgio Agamben. Belo Horizonte: Autêntica, 2013.

CAUQUELIN, A. Arte contemporânea: uma introdução. São Paulo: Martins Fontes, 2005.

CHAGAS, M. S., et al. Museus e público jovem: percepções e receptividades. Revista Eletrônica do Programa de Pós Graduação em Museologia e Patrimônio PPG PMUS UNIRIO/MAST, v. 3, n 1, p. 49-66, jan-jun 2010. Disponível em: < http://revistamuseologiaepatrimonio.mast.br/index.php/ppgpmus/article/ viewFile/94/120>. Acesso em: 10 out. 2017.

CHARTIER, R. O mundo como representação. In Revista de Estudos Avançados, v. 5 no 11. Instituto de Estudos Avançados da Universidade de São Paulo, jan-abr 1991.

A aventura do livro: do leitor ao navegador. São Paulo: Unesp/ Imprensa Oficial do Estado de São Paulo, 1999.

A história cultural - entre práticas e representações. Tradução de Maria Manuela Galhardo. Lisboa: Difusão Editorial, 2002.

(org.) História da Vida Privada: da Renscença ao Século das Luzes. São Paulo: Companhia das Letras, v. 3, 2009

CHOAY, F. A alegoria do patrimônio. São Paulo: Unesp/Estação Liberdade, 2006.

COUTO, M. Os tempos que há no tempo. Palestra na cerimônia de encerramento da 23a Conferência Geral do Conselho Internacional de Museus - ICOM Rio de Janeiro, RJ. (2013).Disponível em http://www.forumpermanente.org/ event_pres/encontros/icom-2013/23-conferencia-do-icom/videos/os-tempos-que-ha-no-tempo. Acesso em 15/04/2016.

CRIMP, D. Sob as ruínas do museu. São Paulo: Martins Fontes, 2005.

DE CERTEAU, M. A invenção do cotidiano: 1. Artes do Fazer. Petrópolis: Vozes, 1994.

A invenção do cotidiano: 2. Morar, cozinhar. Petrópolis: Vozes, 2011.

DÉOTTE, J.-L. Catástrofe y olvido: las ruinas, Europa, El museo. Santiago: Cuarto Próprio, 1998.

DESVALLÉES, A.; MAIRESSE, F. Conceitos-chave de museologia. São Paulo: Comitê Brasileiro do Conselho Internacional de Museus/Pinacoteca do Estado de São 
Paulo/Secretaria de Estado da Cultura, 2013.

DIDI-HUBERMANN, G. O que vemos, o que nos olha. São Paulo: 34, 2010.

DOCTORS, M. Projeto Espiração. Rio de Janeiro: Cobogó/Fundação Eva Klabin, 2012.

DUARTE, A. Nova Museologia: os pontapés de saída de uma abordagem ainda inovadora. Revista Eletrônica do Programa de Pós Graduação em Museologia e Patrimônio-PPG-MUS Unirio/MAST, v. 6, nำ1, p. 99-117, 2013. Disponível em: <https://core.ac.uk/download/pdf/143404132.pdf>. Acesso em: 14/07/2018

EIDELMAN, J.; GOLDSTEIN, B.; ROUSTAN, M. (Org.). O lugar do público: sobre o uso dos estudos e pesquisas pelos museus. São Paulo: Iluminuras/Itaú Cultural, 2014.

ELEB, M.; DEBARRE, A. L'invention de l'habitation moderne. Paris: AAM/Hazan, 1995

FALBEL, A. Bruno et Lina: entre discoussions et disputes... comme des veritábles amis. In: CRICONIA, A.; ESSAIAN, E. Lina Bo Bardi enseignements partagés Paris: Archibooks et Satereau, 2017. p. 51-65.

FELICIANO, F. Y. K. Museu-casa e a arte contemporânea: diálogos com o fetiche. Revista Belas Artes, São Paulo, set-dez 2013.

FIRMO, A. D. O. Exposições de arte brasileira: um estudo de exposições como meio para compreensão dos fundamentos da recepção e da arte contemporânea. (2017). Tese (Doutorado). Faculdade de Arquitetura e Urbanismo da Universidade de São Paulo-FAUUSP, São Paulo, 2017.

FONSECA, M. C. L. O patrimônio em processo: trajetória da política federal de preservação no Brasil. Rio de Janeiro: UFRJ/MinC/IPHAN, 2005.

FOSTER, H. O retorno do real. São Paulo: Cosac Naify, 2014.

O complexo arte-arquitetura. São Paulo: Cosac Naify, 2015.

FRANCO, A. A. D. M. Rodrigues Alves. Rio de Janeiro: Livraria José Olympio Editora, v. 1 e 2, 1973.

Rodrigues Alves: apogeu e declínio do presidencialismo. Brasília: Senado Federal, 2001.

FREYRE, Gilberto. Casa-grande \& senzala. São Paulo: Global, 2006. 
FUNDAÇÃO EVA KLABIN. A coleção Eva Klabin. Rio de Janeiro: Kapa Editorial/ Fundação Eva Klabin, 2007.

GONÇALVES, L. R. Sobre museus: conferências. São Paulo: MACUSP, 2010.

GORELIK, A. Das vanguardas a Brasília: cultura urbana e arquitetura na América Latina. Belo Horizonte: UFMG, 2005

PEIXOTO, F. A. Ciudades sudamericanas como arenas culturales. Buenos Aires: Siglo Veinteuno, 2016.

GRIGOLETO, M. C. A documentação Patrimonial: gênese e fluxo dos processos de tombamento do Museu Prudente de Moraes. (2009). Dissertação (Mestrado em Ciência da Informação). Faculdade de Filosofia e Ciências da Faculdade Estadual Paulista, Marília, 2009.

GUIMARAENS, C. Museografia e arquitetura de museus: conservação e técnicas sensoriais. Rio de Janeiro: FAU-PROARQ, 2010.

HALL, S. A identidade cultural na pós-modernidade. Rio de Janeiro: DP\&A, 2006. ; WOODWARD, K.; SILVA, T. T. D. (Org.). Identidade e diferença: a perspectiva dos estudos culturais. Petrópolis: Vozes, 2000.

HARTOG, F. Temporality and patrimony. Varia Historia, Belo Horizonte, v. 22, p. 261-273, jul/dez 2006.

HARVEY, D. Condição pós-moderna. São Paulo: Loyola, 2002.

Cidades Rebeldes. São Paulo: Martins Fontes, 2014.

HERBST, H. Pelos salões das bienais, a arquitetura ausente dos manuais: expressões da arquitetura brasileira expostas nas bienais paulistanas (1951-1959). (2007). Tese (Doutorado em Arquitetura). Faculdade de Arquitetura e Urbanismo da Universidade de São Paulo-FAUUSP, São Paulo, 2007.

HORTA, M. D. L. P. Museum semiotics: a new aproach to museum communication. Londres: Universidade de Leicester, 1993

HUYSSEN, A. Seduzidos pela memória: arquitetura, monumentos, mídia. Rio de Janeiro: Aeroplano/UCM/MAM/RJ, 2000.

Culturas do passdo-presente. modernismos, artes visuais, políticas da 
memória. Rio de Janeiro: Contraponto/Museu de Arte do Rio de Janeiro, 2014.

IPHAN. Memorial Descritivo do Projeto de Reforma do Estúdio Sarazá para a Casa do Conselheiro Rodrigues Alves, Guaratinguetá, SP. Arquivo IPHAN (6a SR). 2003

IPHAN. Processo n 0849/69 Tombamento da Casa do Conselheiro Rodrigues Alves, Guaratinguetá, SP. Arquivo IPHAN (6a SR). 1969

JAUSS, H. R. A história da literatura como provocação à teoria literária. São Paulo: Ática, 1984.

Pour une esthethique de la reception. Paris: Gallimard, 1990

JEUDY, H. P. Patrimoines en folie. Paris: Editions de la Maison des Sciences de L'Homme, 1990.

KATO, S. Tempo e espaço na cultura japonesa. São Paulo: Estação Liberdade, 2012 KWON, M. Um lugar após o outro. Arte \& Ensaios, Rio de Janeiro, 2008.

LEFEBVRE, H. O direito à cidade. Itapevi, SP: Nebli, 2016.

LEMOS, C. A. C. Alvenaria burguesa. São Paulo: Nobel, 1989.

LEMOS, C. A. C.; MORI, V. H.; ALEMBERT, C. C. D. Patrimônio: 70 anos em São Paulo. São Paulo: 9a SR IPHAN, 2008.

LEÓN ALONSO. A. El museo: teoria, práxis, utopia. Madri: Ed. Cátedra, 1990.

LEON, E. IAC - Primeira escola de design do Brasil. São Paulo: Blucher, 2014

(Org.). Michel Arnoult, design e utopia: móveis em série para todos. São Paulo: SESC, 2017.

LEPETIT, B.; SALGUEIRO, H. A. Por uma nova história urbana. São Paulo: Edusp, 2001.

LES ARTS DECORATIFS. Museé Nissim de Camondo. La demeure d'un collectionneur. Tours: [s.n.], 2007.

LES MUSEÉS DE LA VILLE DE PARIS. Maison de Balzac. Paris: Les Presses Artistiques, 1980.

LES MUSEÉS DE LA VILLE DE PARIS. Maison de Victor Hugo - Guide. Paris: Paris Museés, 2009. 
LIRA, J. O visível e o invisível na arquitetura brasileira. São Paulo: DBA, 2017.

LOURENÇO, M. C. F. Operários da modernidade. São Paulo: Hucitec/Edusp, 1995. Museus acolhem o moderno. São Paulo: Edusp, 1999.

MARIANO, C. Preservação e paisagismo em São Paulo: Otávio Augusto Teixeira Mendes. São Paulo: Fundação Maria Luísa e Oscar Americano/Anablume/ Fapesp, 2005.

MARINS, P. C. G. Habitação e vizinhança: limites da privacidade no surgimento das metrópoles brasileiras. In: SEVCENKO, N. História da vida privada no Brasil. São Paulo: Companhia das Letras, v. 3, 1998. p. 131-214.

MARTINS, C. A. F. Identidade nacional e estado no projeto modernista: modernidade, estado e tradição. In: GUERRA, A. Textos fundamentais sobre arquitetura moderna brasileira - Parte 1. São Paulo: Romano Guerra, 2010.

MENEZES, U. T. B. D. Memória e cultura material: documentos pessoais no espaço público. CEPDOC/FGV: Estudos Históricos, Rio de Janeiro, v. 11, p. 89-104, 1998.

MENEZES, U. T. B. D. O museu e o problema do conhecimento. Anais do IV Seminário sobre Museus-casa: pesquisa e documentação. Rio de Janeiro: Fundação Casa de Rui Barbosa, 2002. p. 17-48.

MENEZES, U. T. B. D. Cultura, política e lugares de memória. Seminário Internacional Culturas Políticas, Memória e Historiografia - PRONEX/FAPERJ/UFRJ. Niterói: UFRJ, 2008.

MICELI, S. Refrigério da cultura oficial. In Revista do IPHAN, nำ 22, p. 44-47. 1987

MISAN, S. Os museus históricos e pedagógicos do Estado de São Paulo. Anais do Museu Paulista, São Paulo, v. 16, p. 175-204, jul-dez 2008.

MONTANER, J. M. Museus para o século XXI. Barcelona: Gustavo Gili, 2003

MOTTA, R. V. D. Museu e cidade: o impasse dos MACs. (2009). Tese (Doutorado em Arquitetura). Faculdade de Arquitetura e Urbanismo da Universidade de São Paulo-FAUUSP, São Paulo, 2009.

NASCIMENTO, F. B. D. et al. Domesticidade, gênero e cultura material. São Paulo: Edusp, 2017 
NEVES, M. H. M. Gramática dos usos da língua portuguesa. São Paulo: Unesp, 2000

NORBERG-SCHULZ, C. Existence, space and architecture. Londres: Studio Vista, 1971.

OKANO, M. [MA] entre-espaço da arte e comunicação no Japão. São Paulo: Annablume, 2012.

OLBRIST, H. U. Uma breve história da curadoria. São Paulo: BEÏ Comunicação, 2010.

ORTIZ, R. Mundialização e cultura. São Paulo: Brasiliense. 1994

PAES, M. E. Oscar Americano - uma história do seu tempo. São Paulo: Ventura, 2008.

PALMER, S. The Soanes at home: domestic life at Lincoln's Inn Fields. Londres: Sir John Soane's Museum, 2010.

PARIS MUSEÉS. Splendeurs et misères de l'ecrivain - une lecture de "la Comédie Humaine" à la Maison de Balzac. Paris: Editions des Museés de la Ville de Paris, 1994

PAVONI, R. Historic house museums speaks to the public: spectacular exhibitsversus a philological interpretation of history. Acts of the Annual Conference Gênova: ICOM international Comitee - Demhist, [s.n.], 2000.

PAVONI, R. Historic house museums as witnessesand local identities. Acts of the Third Annual Demhist Conference. Amsterdam: ICOM INternational Comitee - Demhist, 2003.

PAVONI, R. Case museo - Il gusto dell'abitare in Italia. Roma: Grafica Massimiliano Trombacco, 2011.

PAZ, O. Los Hijos del limo. In: PAZ, O. Casa de la presencia (poesia e historia), Obras Completas. Cidade do México: Fondo de Cultura Económica, 1994. p. 333.

PEREIRA, M.T. As casas de Lina Bo Bardi e os sentidos do habitat. (2014) Tese (Doutorado). Faculdade de Arquitetura e Urbanismo da Universidade de Brasília, 2014

PESSOA, A. Anais do I Encontro Luso Brasileiro de Museus Casas. Rio de Janeiro: Fundação Casa de Rui Barbosa. 2010.

PESSOA, A. II Encontro Luso-Brasileiro de Museus Casas: jardins privados do século XIX. Rio de Janeiro: Fundação Casa de Rui Barbosa. 2011. 
PINHEIRO, M. L. B. Neocolonial, modernismo e preservação do patrimônio no debate cultural dos anos 1920 no Brasil. São Paulo: Edusp, 2011.

POMIAN, K. Coleção. In: GIL, F. História e memória. Lisboa: Casa da Moeda, 1984.

PONTE, A. M. T. D. Casas-museu em Portugal: teorias e práticas 1985-2007. Porto: Faculdade de Letras da Universidade do Porto, 2007.

RAHME, A. M. A. K. Inovar e conservar: a ambiguidade no Monumento Constitucionalista. Tese (Doutorado) Faculdade de Arquitetura e Urbanismo da Universidade do Estado de São Paulo - FAUUSP. São Paulo. 2005.

RAMA, A. A cidade das letras. São Paulo: Boitempo, 2016.

REIS, C. B. Memória de um jardim. Estudo do acervo do Museu Casa de Rui Barbosa. Rio de Janeiro: Casa de Rui Barbosa, 2007.

Rui Barbosa in Encontros Brasileiros de Museus Casas(1:2006 ago 13-18 : Rio de Janeiro, RJ) I Encontro Luso-Brasileiro de Museus Casas - Rio de Janeiro: Fundação Casa de Rui Barbosa, 2010.

RIBEIRO, D. O povo brasileiro: a formação e o sentido do Brasil. São Paulo: Global, 2015.

RICOEUR, P. A memória, a história e o esquecimento. Campinas: Unicamp, 2007.

RISÉRIO, A. A cidade no Brasil. São Paulo: 34, 2013.

RIZOLLI, M. O resgistro patrimonial como arco expressivo: as fotografias de Luciano Alarkon. Revista Gama, Estudos Artísticos, p. 20-27, jan-jun 2017.

RÚSSIO, V. Processo DACH 82.887/77 da Secretaria de Estado da Cultura Ciência e Tecnologia do Estado de São Paulo. Parecer emitido em 06/01/1978. (1978). Arquivo Casa Guilherme de Almeida

RYKWERT, J. A casa de Adão no paraíso: a ideia da cabana primitiva na história da arquitetura. São Paulo: Perspectiva, 2003.

A sedução do lugar - a história e o futuro da cidade. São Paulo: Martins Fontes, 2004.

SANTOS, M. Por uma Geografia Nova. São Paulo: Hucitec, Edusp, 1978. 
Por uma outra globalização: do pensamento único a consciência universal. Rio de Janeiro: Record, 2001.

A urbanização desigual. São Paulo: Edusp, 2012 A

Da totalidade ao lugar. São Paulo: Edusp, 2012 B.

Técnica, espaço, tempo. São Paulo: Edusp, 2013.

A natureza do espaço: técnica e tempo, razão e emoção. São Paulo: Edusp, 2017.

ŞAVAS, A. House museum: A new function for old buildings. Journal of the Faculty of Architecture JFA - Midle East Technical University - METU, Ankara, v. 1, p. 139-160, 2010.

SCARPELINE, R. Lugar de morada como lugar de memória: a construção de uma casa-museu, a Casa de Rui Barbosa-RJ. (2009). Dissertação (Mestrado em História). Instituto de Filosofia e Ciências Humanas da Universidade Estadual de Campinas, Campinas, 2009.

SCHAER, R. L'invention des museés. Paris: Gallimard, 1993.

SECRETARIA DE ESTADO DOS NEGÓCIOS DA EDUCAÇÃO. Museus históricos paulistas. [S.l.]. 1960

SEGAUD, M. Antropologia do espaço - habitar, fundar, distribuir, transformar. São Paulo: SESC, 2016

SEGAWA, H.; DOURADO, G. M. Oswaldo Arthur Bratke - a arte de bem projetar e construir. São Paulo: PW Editores, 2012.

SILVA, J. M. D. C. E. Nacionalismo e arquitetura em Ricardo Severo: Porto 1869 São Paulo 1940. (2005). Dissertação (Mestrado). Departamento de Arquitetura e Urbanismo da Escola de Engenharia de São Carlos da Universidade de São Paulo, São Carlos, 2005.

SILVA, P. Z. D. C. D. A dimensão pública da arquitetura em museus: uma análise de projetos contemporâneos. (2007). Dissertação (Mestrado). Escola de Arquitetura da Universidade Federal de Minas Gerais, Belo Horizonte, 2007.

SIR JOHN SOANE'S MUSEUM. The new descriptionof the Sir John Soane's Museum Londres: Sir John Soane's Museum, 2007. 
SIRE, M.A. La France du patrimoine - Les choix de la mémoire. Paris: Gallimard, 1996

SMITH, C. S. Museums, artifacts and meanings. In: VERGO, P. New museology. Londres: Reaktion Books, 1989.

STROUD, D. The architecture of Sir John Soane. Londres: Studio London, 1961.

SUMMERSON, J. Architecture in Britain - 1530 a 1830. Edinburgo: Penguin Books, 1953.

SYKES, A. K. O campo ampliado da arquitetura: antologia teórica 1993-2009. São Paulo: Cosac Naify, 2013.

TANIZAKI, J. Elogio da sombra. Porto: Relógio d’Água, 2008.

THE FREUD MUSEUM. 20 Maresfield Gardens - a guide to the Freud Museum London. Londres: Lego SPA, 1998.

TRABA, M. Duas décadas vulneráveis nas artes plásticas latino-americanas, 19501970. Rio de Janeiro: Paz e Terra, 1977.

TULCHIN, J. S. América Latina X Estados Unidos: uma relação turbulenta. São Paulo: Contexto, 2016

ULRICH, A. Guilherme de Almeida e a construção da identidade paulista. (2008). Dissertação (Mestrado). Faculdade de Filosofia Letras e Ciências Humanas da Universidade de São Paulo- FFLCHUSP, São Paulo, 2008.

WHITECHAPEL GALLERY. Memory - documents of contemporary arts. Cambridge: The MIT press, 2012.

ZEVI, B. A moda lecorbusiana no Brasil. In: XAVIER, A. Depoimento de uma geração: arquitetura moderna brasileira. São Paulo: Cosac Naify, 2003. p. 163-166 Saber ver a arquitetura. São Paulo: Martins Fontes, 2009.

ZILBERMANN, R. Estética da recepção e história da literatura. São Paulo: Ática, 1989 ZUMTHOR, P. Atmosferas. Barcelona: Litosplai, 2006.

Sites citados: 
http//:www.museupatrimonio.fau.usp.br.>. Acesso a: 26/06/2019

https://www.arca.fiocruz.br/bitstream/icict/15276/4/Programa\%20de\%20incorporao. pdf>. Acesso em: 26/01/2019

http://icom-portugal.org/2015/03/19/definicao-museu/>. Acesso a:12/06/2016

https://www.historiadahistoriografia.com.br/revista/article/viewFile/459/327/>. Acesso a: $15 / 08 / 208$

https://www1.folha.uol.com.br/ilustrissima/2020/01/como-os-super-ricos-assumiram-o-controle-do-mundo-dos-museus.shtml>. Acesso em:02/02/2020

https://www1.folha.uol.com.br/amp/ilustrissima/2020/01/ecossistema-das-artes-merece-as-vaias-que-recebe.shtml. Acesso em: 02/02/2020

https://www.museus.gov.br/wp-content/uploads/2013/09/naopublico.pdf>. Acesso em: 16/01/2019

http://fundacaogilbertofreyre.blogspot.com/>. Acesso em: 15/06/2016

https://www.clp.org.br/guerra-cultural-e-os-impactos-na-gestao-publica-da-cultura-mlg2/>. Acesso em: 15/02/2020

http://portal.iphan.gov.br/pagina/detalhes/173>. Acesso em: 8/03/2017

http://www.museudacidade.sp.gov.br/bandeirante-luissaia.php>. Acesso em: 12/09/2016

http://www.museusliterarios.org.br/. Acesso em 15/01/2018

https://www.dw.com>. Acesso em: 12/06/2016

https://www.mnad.org/index.php?subP=residencia/>. Acesso em: 12/02/2018

www.lesartsdecoratifs.fr>. Acesso em: 15 /10/2018.

http://institutobardi.com.br/>. Acesso em: 10/01/2019

https://www.archdaily.com.br/br/922055/casa-de-niemeyer-esta-abandonada-e-vira-palco-de-disputa-entre-familiares-e-fundacao>. Acesso em: 15/02/2020

http://institutobardi.com.br/?page_id=145>. Acesso em: 14/07/2018 
http://www.forumpermanente.org/convidados/p_herkenhoff>. Acesso em: 12/12/2019 


\section{Créditos Finais}

Capa: Vista aérea de São Paulo. Foto: Lucas Marcomini. Fonte: Site Unsplash.

Essa obra foi composta nas com as famílias tipográficas Museo e Rift Soft.

Revisão to texto: Adrienne Firmo

Tratamento de imagens e desenhos: Camila Sarkis e Felipe Frazão Projeto gráfico: Joana Silveira Mello. 




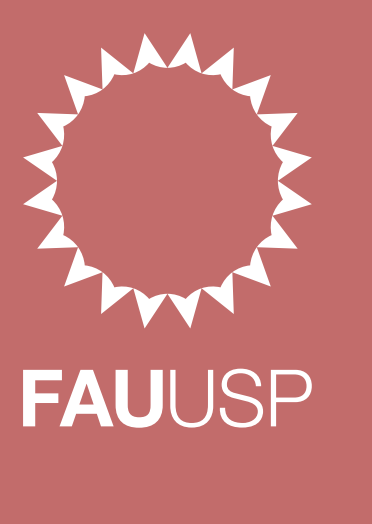

\section{FAUUSP}

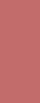

$(2$

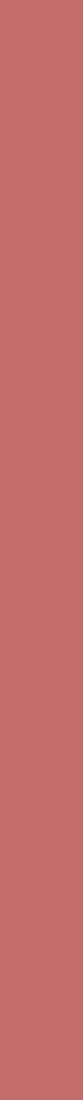

